\title{
Človeški kapital, organizacijska klima in uspešnost poslovanja turističnih podjetij
}

Vojko Kaluža Štefan Bojnec

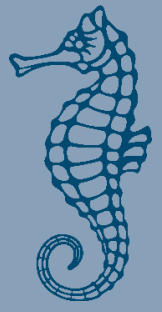


Založba Univerze na Primorskem

University of Primorska Press

Uredniški odbor / Editorial Board

Gregor Pobežin

Maja Meško

Vito Vitrih

Silva Bratož

Ana Petelin

Janko Gravner

Krstivoje Špijunović

Miloš Zelenka

Jonatan Vinkler

Alen Ježovnik

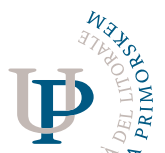

UNIVERT 


\section{Človeški kapital, organizacijska klima in uspešnost poslovanja turističnih podjetij}

Vojko Kaluža Štefan Bojnec

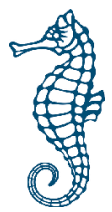


Človeški kapital, organizacijska klima in uspešnost poslovanja

turisticnih agencij

Vojko Kaluža

Štefan Bojnec

Recenzenta

Črtomir Rozman

Boštjan Antončič

Lektura in prelom: Davorin Dukič

Izdala

Založba Univerze na Primorskem

(za založnika: prof. dr. Klavdija Kutnar, rektorica)

Titov trg 4, SI-600o Koper

Glavni urednik

Jonatan Vinkler

Vodja založbe

Alen Ježovnik

Koper 2019

ISBN 978-96I-7055-96-2 (pdf)

http://www.hippocampus.si/ISBN/978-96I-7055-96-2.pdf

ISBN 978-96I-7055-80-I (html)

http://www.hippocampus.si/ISBN/978-96I-7055-80-I/index.html

DOI: https://doi.org/I0.26493/978-96I-7055-96-2

(C) 2019 Univerza na Primorskem

Izdaja je sofinancirana po pogodbi ARRS za sofinanciranje izdajanja znanstvenih monografij v letu 2019 .

\section{(@) $\Theta \Theta$}

Kataložni zapis o publikaciji (CIP) pripravili v Narodni in univerzitetni knjižnici

v Ljubljani

COBISS.SI-ID $=303562752$

ISBN 978-96I-7055-96-2 (pdf)

ISBN 978-96I-7055-80-I (html) 


\section{Vsebina}

\section{$9 \quad$ Slike}

\section{Preglednice}

\section{Kratice}

17 Uvod

I7 Opis ožjega znanstvenega področja in opredelitev raziskovalnega problema

I9 Raziskovalni model

20 Namen in cilji raziskave

20 Temeljna teza in hipoteze

27 Načrt raziskave

27 Metode analize podatkov in testiranje hipotez

28 Predpostavke in omejitve pri obravnavanju raziskovalnega problema

29 Struktura raziskave

\section{I Človeški kapital}

3I Opredelitev človeškega kapitala

36 Intelektualni kapital

38 Izobraževanje, učenje in znanje

40 Kompetence vizobraževanju

4I Učinki izobraževanja in njihovo merjenje

42 Izobraževanje v podjetjih in njegova učinkovitost

48 Učeča se organizacija

49 Vloge in odgovornosti pri razvoju izobraževanja v učeči se organizaciji

50 Timsko delo

50 Ekonomska učinkovitost izobraževanja 


\section{Organizacijska klima}

53 Opredelitev, razvoj in vrste organizacijske klime

55 Dimenzija kakovosti in količine dela v organizaciji

55 Dimenzija inovativnosti in samoiniciativnosti v organizaciji

56 Dimenzija vodenja in participacije v organizaciji

56 Dimenzija nagrajevanja in motiviranja $\mathrm{v}$ organizaciji

57 Napredovanje in premeščanje

58 Dimenzija kakovosti medsebojnih odnosov v organizaciji

59 Dimenzija organiziranja in odgovornosti v organizaciji

59 Dimenzija izobraževanja, izpopolnjevanja in usposabljanja v organizaciji

60 Dimenzija razumevanja in udejanjanja razvojne strategije v organizaciji

60 Dimenzija načina internega komuniciranja v organizaciji

6r Dimenzija informiranosti v organizaciji

6I Dimenzija razvoja in upravljanja kariere v organizaciji

62 Merjenje in spreminjanje organizacijske klime

63 Opredelitev motivacije in pomen motivacije za dobro organizacijsko klimo

67 Turizem

67 Razvoj turizma v Sloveniji

68 Izraz turizem in opredelitev turizma

68 Turistična destinacija in načrtovanje turističnih destinacij

7I Ponudniki turističnih proizvodov

7I Vloga turističnih agencij in organizatorjev turističnih potovanj

74 Turistični kraj in turistična regija

77 Uspešnost poslovanja $v$ turističnih agencijah

$\mathbf{7 8}$ Rast

78 Rast prihodkov od prodaje

$\mathbf{7 8}$ Povečanje števila zaposlenih

79 Povečanje tržnega deleža na domačem in tujem trgu

80 Dobiček

80 Donosnost

8 o Donosnost investicije (ROI)

80 Dobiček glede na sredstva (ROA)

8I Donosnost vloženega kapitala (ROE)

8I Dobičkonosnost TA

\section{Predhodne raziskave na obravnavanem področju}

87 O raziskavi: kvantitativna analiza vpliva dejavnikov uspešnosti poslovanja

87 Ciljna populacija in vzorčenje

88 Metoda zbiranja podatkov

88 Pilotna raziskava za pripravo spletnega anketnega vprašalnika

89 Anketni vprašalnik 
90 Potek raziskave

9I Metode analize podatkov in testiranje hipotez

93 Opisne statistike vzorca anketirancev v turističnih agencijah in njihovih poslovalnicah

93 Sociodemografske značilnosti anketirancev

97 Značilnosti turističnih agencij in njihovih poslovalnic

Ior Človeški kapital

Iо8 Organizacijska klima

II8 Uspešnost poslovanja

I20 Tržni delež na domačem in tujem trgu

I22 Število zaposlenih

123 Donosnost

127 Empirična analiza modela in preverjanje hipotez

127 Analiza komunalitet in ugotovitev faktorjev

I28 Eksplorativna faktorska analiza

129 Modeliranje z linearnimi strukturnimi enačbami, konfirmativna faktorska analiza in strukturni model

I3I Analiza konstrukta človeški kapital

I3I Kodiranje trditev z oceno stopenj strinjanj posamezne dimenzije konstrukta človeški kapital

I34 Eksplorativna faktorska analiza za konstrukt človeški kapital

140 Konfirmativna faktorska analiza za konstrukt človeški kapital

I45 Analiza konstrukta organizacijska klima

I45 Kodiranje trditev z oceno stopenj strinjanj posamezne dimenzije konstrukta organizacijska klima

I48 Eksplorativna faktorska analiza za konstrukt organizacijska klima

I54 Konfirmativna faktorska analiza za konstrukt organizacijska klima

I57 Analiza konstrukta uspešnost poslovanja turističnih agencij

157 Kodiranje trditev z oceno stopenj strinjanj posamezne dimenzije konstrukta uspešnost poslovanja

158 Eksplorativna faktorska analiza za konstrukt uspešnost poslovanja

162 Konfirmativna faktorska analiza za konstrukt uspešnost poslovanja

I65 Preverjanje hipotez

I65 Preverjanje $\mathrm{H}_{\mathrm{r}}$ : Med človeškim kapitalom in organizacijsko klimo v turističnih agencijah obstaja pozitivna medsebojna povezava

178 Preverjanje $\mathrm{H}_{2}$ : Človeški kapital pozitivno vpliva na uspešnost poslovanja turističnih agencij

I84 Preverjanje $\mathrm{H}_{3}$ : Organizacijska klima pozitivno vpliva na uspešnost poslovanja turističnih agencij 
I93 Razvoj celotnega strukturnega modela vpliva človeškega kapitala in organizacijske klime na uspešnost poslovanja

193 Strukturni model povezanosti človeškega kapitala in organizacijske klime

197 Strukturni model vpliva človeškega kapitala na uspešnost poslovanja

199 Strukturni model vpliva organizacijske klime na uspešnost poslovanja

20I Celotni strukturni model vpliva človeškega kapitala in organizacijske klime na uspešnost poslovanja

207 Povzetek ugotovitev raziskave

213 Prispevek k znanosti in stroki

215 Implikacije

215 Konstrukt človeški kapital

216 Konstrukt organizacijska klima

216 Konstrukt uspešnost poslovanja

217 Predlogi za nadaljnje raziskovanje

219 Povzetek

223 Summary

227 Literatura

237 Recenziji

237 I

238 II 


\section{Slike}

19 Slika I: Raziskovalni model

32 Slika 2: Skandiina vrednostna shema

32 Slika 3: Človeški kapital (sposobnost ljudi in sposobnost učenja)

136 Slika 4 : Kolenski diagram lastnih vrednosti za konstrukt človeški kapital in faktorji s pripadajočimi dejavniki konstrukta človeški kapital

I42 Slika 5: Diagram konstrukta človeški kapital s standardizirano rešitvijo

I5I Slika 6: Kolenski diagram lastnih vrednosti za konstrukt organizacijska klima in faktorji s pripadajočimi dejavniki konstrukta organizacijska klima

I55 Slika 7: Diagram konstrukta organizacijska klima s standardizirano rešitvijo

I60 Slika 8: Kolenski diagram lastnih vrednosti za konstrukt uspešnost poslovanja in faktorji s pripadajočimi dejavniki konstrukta uspešnost poslovanja

162 Slika 9: Diagram konstrukta uspešnost poslovanja s standardizirano rešitvijo

194 Slika Io: Strukturni model povezanosti človeškega kapitala in organizacijske klime

197 Slika Ir: Strukturni model vpliva človeškega kapitala na uspešnost poslovanja

200 Slika I2: Strukturni model vpliva organizacijske klime na uspešnost poslovanja

202 Slika I3: Celotni strukturni model povezanosti človeškega kapitala in organizacijske klime ter njunega vpliva na uspešnost poslovanja 



\section{Preglednice}

27 Preglednica I: Načrt raziskave

93 Preglednica 2: Spol

94 Preglednica 3: Starost

94 Preglednica 4: Število let zaposlitve na področju turizma

95 Preglednica 5: Število let zaposlitve v trenutni turistični agenciji/poslovalnici

95 Preglednica 6: Zaključena stopnja izobrazbe

96 Preglednica 7: Vrsta zaposlitve

96 Preglednica 8: Funkcija zaposlitve

97 Preglednica 9: Glavna dejavnost turistične agencije/poslovalnice glede na standardno klasifikacijo dejavnosti (SKD)

97 Preglednica ıo: Vrsta licence za dejavnost pri Gospodarski zbornici Slovenije

98 Preglednica II: Organizacijski status

98 Preglednica ı2: Pravni status

99 Preglednica 13: Delež (\%) preučevanih dejavnosti v turistični agenciji/poslovalnici

I०० Preglednica I4: Število zaposlenih v turistični agenciji/poslovalnici

I00 Preglednica I5: Pokritost trga (domači, tuji) glede na opravljanje dejavnosti

IoI Preglednica I6: Dejavnost (emitivni turizem, receptivni turizem) glede na državljanstvo gostov (izletnikov, turistov, obiskovalcev)

IO2 Preglednica 17: Pridobivanje znanja

I03 Preglednica I8: Shranjevanje znanja

103 Preglednica 19: Prenos znanja

I05 Preglednica 20: Uporaba znanja

I06 Preglednica 2r: Vrsta (način) izobraževanja

107 Preglednica 22: Čas izobraževanja

I08 Preglednica 23: Odnos do kakovosti

I09 Preglednica 24: Inovativnost (izboljšave, dvig kakovosti, nižji stroški poslovanja) in iniciativnost (aktivno iskanje priložnosti za lasten prispevek rezultatom) 
Preglednica 25: Strokovna usposobljenost in učenje Preglednica 26: Motivacija in zavzetost

Preglednica 27: Notranja komunikacija in informiranje

Preglednica 28: Vodenje (delegiranje) dela

Preglednica 29: Notranji odnosi

Preglednica 30: Poznavanje poslanstva, vizije, ciljev

Preglednica 31: Organiziranost dela

Preglednica 32: Pripadnost organizaciji

Preglednica 33: Razvoj kariere

Preglednica 34: Nagrajevanje glede na uspešnost

Preglednica 35: Zadovoljstvo zaposlenih

Preglednica 36: Prihodki od prodaje

Preglednica 37: Prihodki od prodaje so se povečali/zmanjšali/ostali dokaj enaki

Preglednica 38: Dobiček

Preglednica 39: Dobiček se je povečal/zmanjšal/ostal dokaj enak

Preglednica 40: Dobičkonosnost TA/poslovalnice glede na konkurenčne turistične agencije, ki jih poznate, v obdobju 20II-2013 v primerjavi z obdobjem 2008-2010 Preglednica 41: Dobičkonosnost TA/poslovalnice glede na turistične agencije, ki so na trgu enako število let in v enaki fazi razvoja ter jih poznate, v obdobju 20II-2013 v primerjavi z obdobjem 2008-2010

Preglednica 42: Tržni delež na domačem trgu

Preglednica 43: Tržni delež na domačem trgu se je povečal/zmanjšal/ostal dokaj enak

Preglednica 44: Tržni delež na tujem trgu

Preglednica 45: Tržni delež na tujem trgu se je povečal/zmanjšal/ostal dokaj enak

Preglednica 46: Število zaposlenih

Preglednica 47: Število zaposlenih se je povečalo/zmanjšalo/ostalo nespremenjeno

Preglednica 48: Zadovoljstvo z donosnostjo v obdobju 20II-2013

Preglednica 49: Merjenje učinkovitosti uporabe znanja

Preglednica 50: Izvorna kodiranja dimenzij ČK v anketnem vprašalniku, kodiranja v SPSS in njihova uporaba v analizah ter trditve, ki se nanašajo na posamezne trditve Preglednica sı: KMO in BT v okviru konstrukta človeški kapital Preglednica 52: Komunalitete spremenljivk konstrukta človeški kapital Preglednica 53: Lastne vrednosti in skupna pojasnjena varianca izločenih faktorjev za konstrukt človeški kapital

Preglednica 54: Rotirana faktorska matrika za konstrukt človeški kapital Preglednica 55: Matrika korelacij med faktorji konstrukta človeški kapital Preglednica 56: Standardizirani regresijski koeficienti in stopnje značilnosti za konstrukt človeški kapital

6 Preglednica 57: Izvorna kodiranja dimenzij konstrukta $\mathrm{OK}$ v anketnem vprašalniku, kodiranja v SPSS in njihova uporaba v analizah ter trditve, ki se nanašajo na posamezne trditve Preglednica 58: KMO in BT v okviru konstrukta organizacijska klima Preglednica 59: Komunalitete spremenljivk konstrukta organizacijska klima 
151 Preglednica 60: Lastne vrednosti in pojasnjene variance izločenih faktorjev za konstrukt organizacijska klima

152 Preglednica 61: Rotirana faktorska matrika za konstrukt organizacijska klima

153 Preglednica 62: Korelacije med faktorji konstrukta organizacijska klima

156 Preglednica 63: Standardizirani regresijski koeficienti in stopnje značilnosti za konstrukt organizacijska klima

I58 Preglednica 64: Izvorna kodiranja dimenzij konstrukta UP v anketnem vprašalniku, kodiranja $v$ SPSS in njihova uporaba $v$ analizah ter trditve, ki se nanašajo na posamezne trditve

158 Preglednica 65: KMO in BT v okviru konstrukta uspešnost poslovanja

159 Preglednica 66: Komunalitete spremenljivk konstrukta uspešnost poslovanja

160 Preglednica 67: Lastne vrednosti in skupne pojasnjene variance izločenih faktorjev za konstrukt uspešnost poslovanja

16I Preglednica 68: Rotirana faktorska matrika za konstrukt uspešnost poslovanja

16I Preglednica 69: Korelacije med faktorji konstrukta uspešnost poslovanja

163 Preglednica 70: Standardizirani regresijski koeficienti in stopnje značilnosti za konstrukt uspešnost poslovanja

166 Preglednica 71: Neodvisne spremenljivke konstrukta človeški kapital in upoštevane odvisne spremenljivke konstrukta organizacijska klima

167 Preglednica 72: Ocena regresijskega modela za človeški kapital in notranje odnose kot sestavino organizacijske klime

167 Preglednica 73: Koeficienti regresijskega modela spremenljivk človeškega kapitala in spremenljivke notranji odnosi kot sestavina organizacijske klime

168 Preglednica 74: Ocena regresijskega modela za človeški kapital in vodenje (delegiranje dela) kot sestavino organizacijske klime

169 Preglednica 75: Koeficienti regresijskega modela spremenljivk človeškega kapitala in spremenljivke vodenje (delegiranje dela) kot sestavina organizacijske klime

170 Preglednica 76: Ocena regresijskega modela za človeški kapital in pripadnost organizaciji kot sestavino organizacijske klime

171 Preglednica 77: Koeficienti regresijskega modela spremenljivk človeškega kapitala in spremenljivke pripadnost organizaciji kot sestavina organizacijske klime

172 Preglednica 78 : Ocena regresijskega modela za človeški kapital in razvoj kariere kot sestavino organizacijske klime

173 Preglednica 79: Koeficienti regresijskega modela spremenljivk človeškega kapitala in spremenljivke razvoj kariere kot sestavina organizacijske klime

174 Preglednica 80: Ocena regresijskega modela za človeški kapital ter zadovoljstvo zaposlenih in nagrajevanje kot sestavino organizacijske klime

175 Preglednica 8ı: Koeficienti regresijskega modela spremenljivk človeškega kapitala ter spremenljivke zadovoljstvo zaposlenih in nagrajevanje kot sestavina organizacijske klime

176 Preglednica 82: Ocena regresijskega modela za človeški kapital ter strokovno usposobljenost in učenje kot sestavino organizacijske klime 
176 Preglednica 83: Koeficienti regresijskega modela spremenljivk človeškega kapitala ter spremenljivke strokovna usposobljenost in učenje kot sestavina organizacijske klime

177 Preglednica 84: Povzetek preverjanja hipoteze $\mathrm{H}_{\mathrm{I}}$

178 Preglednica 85: Neodvisne spremenljivke konstrukta človeški kapital in upoštevane odvisne latentne spremenljivke konstrukta uspešnost poslovanja

179 Preglednica 86: Ocena regresijskega modela za človeški kapital in donosnost kot sestavino uspešnosti poslovanja

180 Preglednica 87: Koeficienti regresijskega modela spremenljivk človeškega kapitala in spremenljivke donosnost kot sestavina uspešnosti poslovanja

I8I Preglednica 88: Ocena regresijskega modela za človeški kapital in rast kot sestavino uspešnosti poslovanja

182 Preglednica 89: Koeficienti regresijskega modela spremenljivk človeškega kapitala in spremenljivke rast kot sestavina uspešnosti poslovanja

I82 Preglednica 90: Ocena regresijskega modela za človeški kapital in dobičkonosnost TA kot sestavino uspešnosti poslovanja

I83 Preglednica 9r: Koeficienti regresijskega modela spremenljivk človeškega kapitala in spremenljivke dobičkonosnost TA kot sestavina uspešnosti poslovanja

I84 Preglednica 92: Povzetek preverjanja hipoteze $\mathrm{H}_{2}$

185 Preglednica 93: Neodvisne spremenljivke konstrukta organizacijska klima in upoštevane odvisne latentne spremenljivke konstrukta uspešnost poslovanja

I86 Preglednica 94: Ocena regresijskega modela za organizacijsko klimo in donosnost kot sestavino uspešnosti poslovanja

I87 Preglednica 95: Koeficienti regresijskega modela spremenljivk organizacijska klima in donosnost kot sestavina uspešnosti poslovanja

187 Preglednica 96: Ocena regresijskega modela za organizacijsko klimo in rast kot sestavino uspešnosti poslovanja

I88 Preglednica 97: Koeficienti regresijskega modela spremenljivk organizacijske klime in rasti kot sestavine uspešnosti poslovanja

I89 Preglednica 98: Ocena regresijskega modela za organizacijsko klimo in dobičkonosnost TA kot sestavino uspešnosti poslovanja

190 Preglednica 99: Koeficienti regresijskega modela spremenljivk organizacijska klima in dobičkonosnost TA kot sestavina uspešnosti poslovanja

190 Preglednica Ioo: Povzetek preverjanja hipoteze $\mathrm{H}_{3}$

195 Preglednica IOI: Standardizirani regresijski koeficienti in njihove statistične značilnosti za strukturni model povezanosti človeškega kapitala in organizacijske klime

198 Preglednica I02: Standardizirani regresijski koeficienti in njihove statistične značilnosti za strukturni model vpliva človeškega kapitala na uspešnost poslovanja

200 Preglednica I03: Standardizirani regresijski koeficienti in njihove statistične značilnosti za strukturni model vpliva organizacijske klime na uspešnost poslovanja

203 Preglednica I04: Standardizirani regresijski koeficienti in njihove statistične značilnosti za konstrukte celotnega strukturnega modela vpliva človeškega kapitala in organizacijske klime na uspešnost poslovanja 


\section{Kratice}

AMOS

BSC

BT

$\mathrm{d} / \mathrm{z}$

EFA

GZS

HRM

$\mathrm{KMO}$

$1 / \mathrm{m} / \mathrm{v}$

$\mathrm{ML}$

$\mathrm{p} / \mathrm{o}$

ROA

ROE

ROI

Scree Plot

SEM

$\mathrm{SiOK}$

SKD analysis of moment structures (analiza struktur)

balanced scorecard, uravnotežen sistem kazalnikov

(USK)

Bartlettov test

drugi zaposleni

exploratory factor analysis (eksplorativna faktorska

analiza v multivariatni statistiki)

Gospodarska zbornica Slovenije

upravljanje s človeškimi viri (ravnanje z ljudmi pri delu)

Kaiser-Meyer-Olkinova mera ustreznosti vzorca

lastnik/manager/vodja

maximum likelihood (metoda najvišjega verjetja)

preučevano obdobje (obdobje ene triade - treh preu-

čevanih koledarskih let turističnih agencij in njihovih

poslovalnic)

return on assets (dobiček glede na sredstva ali obvezno-

sti do virov sredstev)

return on equity (donosnost vloženega kapitala)

return on investments (donosnost vloženih sredstev)

kolenski diagram (diagram lastnih vrednosti)

structural equation modelling (modeliranje $\mathrm{z}$ linearni-

mi strukturnimi enačbami)

Slovenska organizacijska klima

Standardna klasifikacija dejavnosti 
SRS

strategija razvoja Slovenije

TA

turistična agencija 


\section{Uvod}

V uvodnem delu raziskave predstavljamo ožje znanstveno področje in opredelitev raziskovalnega modela, namen in cilje raziskave, temeljno tezo in hipoteze raziskave, načrt raziskave, metode analize podatkov in testiranje hipotez, predpostavke in omejitve pri obravnavanju raziskovalnega problema ter strukturo raziskave.

\section{Opis ožjega znanstvenega področja in opredelitev raziskovalnega problema}

Raziskava preučuje vpliv dejavnikov človeškega kapitala in organizacijske klime na uspešnost poslovanja turističnih agencij. Vsebina spada na področje ekonomije in managementa oz. po klasifikaciji Frascati v 5.02: ekonomske in poslovne vede.

Raziskovalni cilj je raziskati precej neraziskano področje človeškega kapitala, organizacijske klime in turističnih agencij ter ugotoviti vpliv dejavnikov človeškega kapitala in organizacijske klime na uspešnost poslovanja turističnih agencij. Omenjeni dejavniki so v veliki meri odvisni od managerjev/lastnikov/vodij turističnih agencij in tudi od drugih zaposlenih, zato je zelo pomembno, da jim namenimo več pozornosti. $Z$ empirično raziskavo želimo ugotoviti, kakšen pomen imajo posamezne spremenljivke človeškega kapitala in organizacijske klime, ki vplivajo na uspešnost poslovanja turističnih agencij. Zavedati se moramo, da turistične agencije igrajo čedalje pomembnejšo vlogo tudi na mednarodnem trgu, ki se mu je treba $\mathrm{v}$ številnih primerih prilagoditi. Konkurenca je vse večja, zato bosta človeški kapital in organizacijska klima čedalje pomembnejša, saj bodo 
turistične agencije lahko uspešno poslovale le, če jima bodo posvetile več pozornosti.

O vplivu organizacijske klime na uspešnost podjetij je znanega kar veliko, še zlasti zaradi desetletnega raziskovanja in spremljanja organizacijske klime v slovenskih organizacijah (Biro Praxsis 20r4), kar se je izvajalo preko Gospodarske zbornice Slovenije (GZS) v okviru projekta SiOK (Slovenska organizacijska klima). O pomenu človeškega kapitala je v zadnjem obdobju nastalo veliko teoretičnih opredelitev, manj pa je empirično podprtih, še zlasti na področju turizma, sploh turističnih agencij, ki imajo zelo pomembno vlogo pri emitivnem in receptivnem turizmu $\mathrm{v}$ Sloveniji. Prav zato želimo temeljno tezo in hipoteze potrditi na podlagi empirične raziskave.

Uspešnost in učinkovitost podjetja sta danes veliko bolj kot kdaj prej odvisni od uspešnosti in odvisnosti managementa človeškega kapitala $\mathrm{v}$ podjetju (Lawler in Mobrman 2003). V zadnjem obdobju se podjetja srečujejo z zniževanjem stroškov, po drugi strani pa so potrebna čedalje večja vlaganja $\mathrm{v}$ človeški kapital. Za podjetja je zelo pomemben tudi intelektualni kapital, ki je po eni izmed opredelitev največkrat nezabeležena vrednost, ki pa je po navadi ne moremo poiskati v finančnih zapisih. Edini vidni primeri intelektualnega kapitala so lahko blagovne znamke, avtorske pravice, znanje zaposlenih, zaščitne znamke, raziskave, razvoj ipd. (Buckley 2000).

Za podjetje, kot profitno organizacijo, je doseganje ekonomskega cilja osnovni motiv za obstoj. Ta cilj neposredno dosega z delovanjem na ekonomskem področju, posredno in v daljšem časovnem obdobju pa tudi na neekonomskih področjih, kamor uvrščamo širše družbeno dogajanje socialno dejavnost, kulturo, vzgojo in izobraževanje. Tako za ekonomsko kot za druga navedena področja podjetje oblikuje svoje politike, pri čemer mora vedno upoštevati svoj ekonomski cilj (Biloslavo 2008, I8).

Roos idr. (2000) človeški kapital razdelijo v podskupine. Vrednost človeškega kapitala izvira iz zmožnosti, odnosa in intelektualne prožnosti. Zmožnosti ustvarjajo vrednost $\mathrm{z}$ znanjem, veščinami, nadarjenostjo. Znanje (Roos idr. 2000) pomeni tehnično ali akademsko poznavanje stvari in je $\mathrm{v}$ glavnem povezano $s$ stopnjo izobrazbe. Znanje je $\mathrm{v}$ bistvu nekaj, česar se moramo naučiti. Ni nujno, da ga pridobimo v šolah oz. na univerzi (tudi terensko usposabljanje je popolnoma sprejemljivo), v vsakem primeru pa se ga je treba naučiti.

$\mathrm{K}$ razvoju in krepitvi zavedanja o pomenu intelektualnega kapitala za rast dodane vrednosti je prispevala vrsta okoliščin, med njimi zlasti dinamične, tehnološke, ekonomske in socialno-politične spremembe. $Z$ njimi 
so nastajala nova spoznanja in se oblikovali drugačni pogledi na intelektualni kapital kot razvojni dejavnik (Bahun in Rojc 2006).

Zmogljivost podjetja se ne odraža samo skozi znanje. Zajema uporabo znanja v kombinaciji z izkušnjami. Sposobnosti oz. zmogljivosti podjetja $\mathrm{v}$ takšnem smislu pa neposredno vplivajo na uspešnost podjetja, medtem ko ga samo znanje, tako tacitno kot eksplicitno, brez posebne operacionalizacije, nima (Schotter in Bontis 2009). Namen izobraževanja zaposlenih $\mathrm{v}$ podjetjih je imeti ustrezno usposobljen kader, ki bi s svojim znanjem znal povečati uspešnost in učinkovitost podjetja. Armstrong (1995) meni, da je to možno le, če ima »vsak zaposleni določene sposobnosti, spretnosti in znanje, ki pripomorejo k učinkovitosti, če se kakovost dela posameznikov in timov izboljšuje, če se zaposleni razvijajo v smeri, ki omogoča največji možni osebnostni razvoj«.

\section{Raziskovalni model}

Raziskovalni model, prikazan v sliki I, ponazarja, za kakšne korelacije gre med dimenzijami organizacijske klime, dimenzijami uspešnosti poslovanja turističnih agencij in dimenzijami človeškega kapitala.

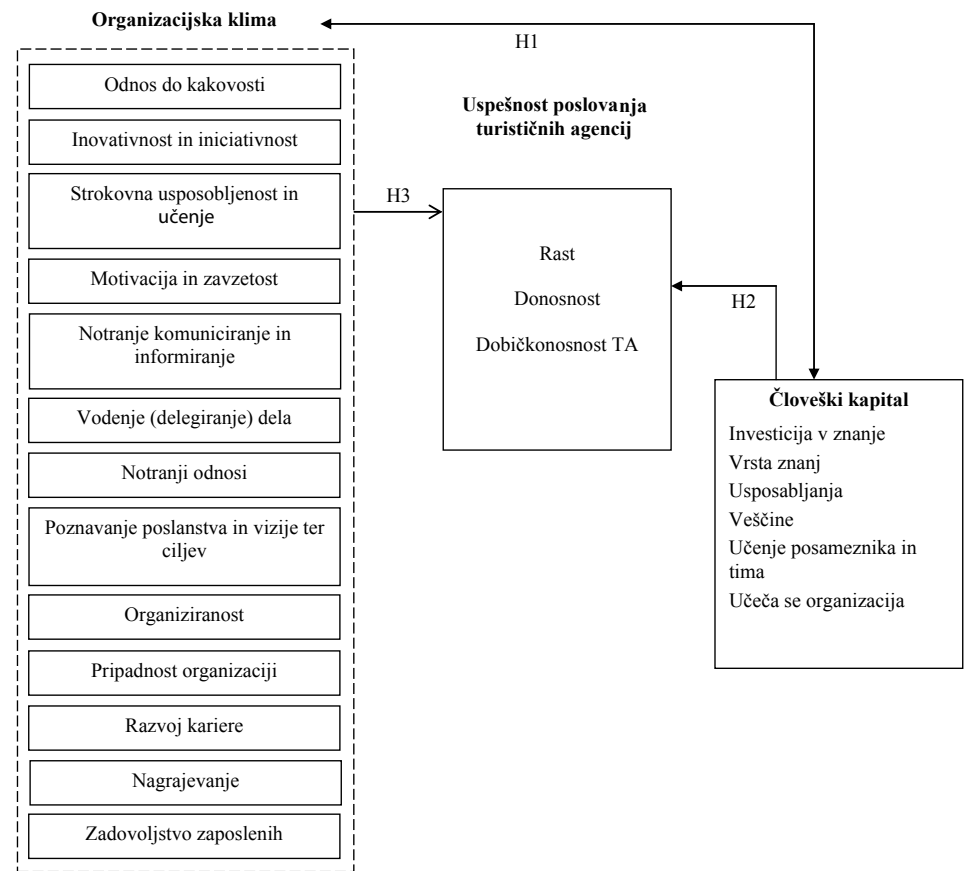

Slika ı: Raziskovalni model 


\section{Namen in cilji raziskave}

Namen raziskave je preučiti vpliv dejavnikov človeškega kapitala in organizacijske klime na uspešnost poslovanja turističnih agencij.

Cilji raziskave so:

- raziskati precej neraziskano temo in dodati svoj znanstveni prispevek s področja človeškega kapitala, organizacijske klime in turizma;

- opredeliti organizacijsko strukturo ter vlogo in pomen deležnikov v slovenskem turističnem gospodarstvu;

- s pomočjo vprašalnika opraviti kvantitativno raziskavo v slovenskih turističnih agencijah, katerih glavna dejavnost je navedena pri ciljni populaciji in vzorčenju, ter razviti in empirično preveriti konceptualni model, ki prek zastavljenih hipotez ponazarja vpliv dejavnikov človeškega kapitala in organizacijske klime na uspešnost poslovanja turističnih agencij;

- na osnovi teoretičnih in empiričnih ugotovitev predstaviti predloge za večji vpliv dejavnikov človeškega kapitala in organizacijske klime na uspešnost poslovanja turističnih agencij ter z empiričnimi podatki preučevano tudi znanstveno objaviti.

\section{Temeljna teza in hipoteze}

Temeljna teza je: »Človeški kapital in organizacijska klima pozitivno vplivata na uspešnost poslovanja turističnih agencij.«

Temeljno tezo smo testirali s pomočjo hipotez $\mathrm{H}_{1}, \mathrm{H}_{2}$ in $\mathrm{H}_{3}$, zapisanih v nadaljevanju.

$H_{I}$ : Med človeškim kapitalom in organizacijsko klimo $v$ turističnih agencijah obstaja pozitivna medsebojna povezava.

\section{Obrazložitev:}

Človeški kapital v turističnih agencijah smo preučevali kot odnos podjetja do izboljšanja človeškega kapitala, kar se nanaša na: investicije v znanje, vrsto znanj, usposabljanja, veščine, učenje posameznikov in tima, učečo se organizacijo.

Organizacijsko klimo smo preučevali z naslednjimi dimenzijami, povzetimi po SiOK: odnos do kakovosti, inovativnost in iniciativnost, pripadnost organizaciji, notranji odnosi, vodenje (delegiranje) dela, organiziranost, strokovna usposobljenost in učenje, poznavanje poslanstva in 
vizije ter ciljev, notranje komuniciranje in informiranje, razvoj kariere, nagrajevanje in zadovoljstvo zaposlenih.

Pri dimenzijah organizacijske klime smo uporabili faktorsko analizo in metodo glavnih komponent.

Povezanost med konstruktoma človeški kapital in organizacijska klima smo preverili z uporabo modeliranja, natančneje z linearnimi strukturnimi enačbami (angl. structural equation modelling - SEM).

Za uporabo metode SEM smo se odločili, ker lahko preverjamo konceptualne modele kot celote in ne samo kot povezave med posameznimi spremenljivkami ali skupinami spremenljivk. Metodo SEM bomo izvedli ob uporabi statističnega programa SPSS (angl. statistical package for the social sciences) in programskega paketa AMOS (angl. analysis of moment structure).

$\mathrm{V}$ raziskavi o izmenjavi znanja in uspešnosti inovacij na področju storitev (Hu, Horng in Sun 2008) je bilo ugotovljeno, da izmenjava znanja in organizacijska klima pomembno vplivata na inovacijsko uspešnost storitev. Rezultati te študije so podprli vlogo skupine in organizacijske klime pri ohranjanju in modeliranju odnosov med izmenjavo znanja ter inovacijsko uspešnostjo storitev. $Z$ raziskavo, izvedeno $\mathrm{v}$ mednarodnih turističnih hotelih, so ugotovili, da so odnosi med izmenjavo znanja, organizacijsko klimo in inovacijsko uspešnostjo storitev pomembni in močni. Glavna skupna ugotovitev empirične raziskave je bila, da morajo v hotelih najprej razviti znanja in vedenja o delitvi dela in boljši organizacijski klimi.

Zadovoljstvo z delom spada $\mathrm{k}$ naravnanosti do dela. Opredeljeno je kot želeno ali pozitivno čustveno stanje, ki je rezultat ocene posameznikovega dela ali doživetja in izkušenj pri njegovem delu. Pri zadovoljstvu gre za individualno afektiven odgovor na delovno okolje, pri klimi pa za skupno sliko organizacijskega okolja zaposlenih. Na zadovoljstvo pri delu vpliva veliko število dejavnikov, med drugim tudi delo samo, možnosti napredovanja, osebne značilnosti, slog vodenja idr., vendar pa je morda prav organizacijska klima tista, ki je najbolj neposredno povezana z zadovoljstvom zaposlenih. Pri tem je povezava med njima recipročna - tako kot organizacijska klima vpliva na zadovoljstvo, tudi zadovoljstvo vpliva na to, kako zaposleni zaznavajo in doživljajo organizacijsko klimo v organizaciji (Biro Praxsis 2014).

Ena izmed znanstvenih študij (Neal, West in Patterson 2005) je preučila, ali je učinkovitost upravljanja človeških virov (angl. human resource management - HRM) odvisna od organizacijske klime in konkurenčne 
strategije. Pojma notranjega in zunanjega prileganja kažeta, da bo pozitiven odnos med HRM-jem in kasnejšo produktivnostjo močnejši za podjetja s pozitivno organizacijsko klimo in za podjetja, ki uporabljajo strategije diferenciacije.

Cilji podjetja so različni. Prvi cilj podjetja, o katerem ni dvoma, je dolgoročno preživetje na trgu. Podjetja lahko zasledujejo še druge cilje: rast in širjenje, doseganje zadovoljstva zaposlenih (ali določene skupine zaposlenih, npr. materam prijazno podjetje), veljave in ugleda, vplivanje na lokalna ali širša dogajanja, prizadevanja na etičnem, socialnem in športnem področju, kjer podjetja lahko nastopajo kot donatorji in sponzorji različnih prireditev ter promocijskih aktivnosti (Bojnec idr. 2007, 57).

Organizacijska klima je lastnost organizacije (Fatur in Likar 2009, 43), ki opredeljuje način, kako ta deluje v vsakodnevnih, rutinskih okoliščinah. Ustvarjajo jo člani organizacije prek organizacijskih običajev, načinov ravnanja in sistemov nagrajevanja. V nekem smislu je koncentrat bistvenih prioritet organizacije.

\section{H2: Človeški kapital pozitivno vpliva na uspešnost poslovanja turistič- nih agencij.}

\section{Obrazložitev:}

Preučevanje človeškega kapitala je navedeno v hipotezi ena (HI), uspešnost poslovanja pa bomo preučevali z:

- rastjo: prihodki od prodaje, povečanje števila zaposlenih, povečanje tržnega deleža na domačem in tujem trgu ter dobiček;

- donosnostjo: donosnost vloženih sredstev - torej naložbe, ki je razmerje med dobičkom in sredstvi, vloženimi v naložbo (angl. return on investments - ROI), dobiček glede na sredstva ali obveznosti do virov sredstev (angl. return on assets - ROA) kot razmerje med dobičkom in vloženimi sredstvi delničarja (lastnika), kar pomeni, da gre za donosnost lastnega kapitala, ter kot razmerje med dobičkom in trajnim kapitalom oz. med dolgoročnimi obveznostmi sredstev, kar pomeni, da gre za donosnost vloženega kapitala (angl. return on equity - ROE);

- dobičkonosnostjo TA: povprečna stopnja iz dobička iz celotnih sredstev, povprečna stopnja iz dobička iz lastniškega kapitala, dobičkonosnost podjetja $\mathrm{v}$ primerjavi z vsemi konkurenčnimi podjetji, ki jih respondenti poznajo, in dobičkonosnost glede na kon- 
kurenčna podjetja, ki so približno enake starosti in $\mathrm{v}$ enaki fazi razvoja.

Povezanost človeškega kapitala in uspešnost poslovanja smo preverjali s pomočjo metode modeliranja z linearnimi strukturnimi enačbami - SEM.

Delaney in Huselid (1996) sta npr. v svoji raziskavi o vplivu praks ravnanja z ljudmi na uspešnost podjetja slednjo operacionalizirala $\mathrm{z}$ dvema naboroma subjektivnih meril: z zaznavanjem splošnih dosežkov podjetja (glede kakovosti in uvajanja novih izdelkov, privabljanja in ohranjanja zaposlenih, kakovosti odnosov v podjetju in zadovoljstva strank) in z zaznavanjem dosežkov podjetja na trgu v obdobju zadnjih treh let.

$\mathrm{Za}$ večjo uspešnost slovenskega turizma (Vlada RS 20I2) je najpomembnejši dvig konkurenčnosti, kar dosežemo z dvigom kakovosti in zadovoljstva gostov - na ravni turističnih ponudnikov, na ravni turističnih ciljev in na nacionalni ravni. Na omenjeno uspešnost vplivajo vsi deležniki slovenskega turizma, med katere spadajo tudi turistične agencije, pri čemer dimenzije človeškega kapitala in organizacijske klime predstavljajo ključ do uspešnosti poslovanja $\mathrm{v}$ turističnih agencijah.

Transformacijsko vodenje (Garcia-Morales, Jimenez-Barrionuevo in Gutierrez-Gutierrez 2010) vpliva na uspešnost delovanja organizacije prek organizacijskega učenja in inovacij. Študija analizira vplive vodenja na organizacijsko uspešnost skozi dinamične zmogljivosti organizacijskega učenja in inovacij. Te vplive potrjuje $z$ empirično analizo, ki temelji na vzorcu 168 podjetij iz Španije in ugotavlja, da transformacijsko vodenje na organizacijsko uspešnost vpliva pozitivno, in sicer prek organizacijskega učenja in inovacij.

B. Kostanjevec in D. Gomezelj Omerzel (2013) ugotavljajta, da je uspešnost podjetja več kot le dobiček ali kakšen drugačen pokazatelj finančne uspešnosti. Po njunem mnenju je treba upoštevati vidike večine udeležencev podjetja - zaposlene, kupce in tudi dobavitelje. Menita, da profit že dolgo ni več edino merilo poslovne uspešnosti, zato se poslovni analitiki čedalje pogosteje usmerjajo na nefinančna merila.

Lumpkin in Dess (1996) priporočata, da bi morali pokazatelje, kot so splošno zadovoljstvo in nefinančni cilji lastnikov, celo bolj upoštevati pri ocenjevanju uspešnosti, še posebej med podjetji v zasebni lasti. Nadalje kot sveženj virov pri družinskih podjetjih navajata šest elementov, ki so: ugled, izkušnje - razumevanje in veščine, učenje, odločanje, odnosi in omrežja. 
V znanstveni študiji primera iz Slovenije s področja intelektualnega kapitala (Nemec Rudež in Mihalič 2007) je bilo ugotovljeno, da so klasični intelektualni kapital in njegove vloge obravnavale tri kategorije: človeški, strukturni in odnosni kapital. Raziskava je šla pri razvijanju modela intelektualnega kapitala za hotelsko industrijo še korak dlje in odnosni kapital deli v dve kategoriji: ena je odnosni kapital - končni kupec, ki se nanaša samo na odnose $s$ končnimi kupci, druga pa odnosni kapital, ki zajema odnose z vsemi drugimi strankami in/ali partnerji. Uporaba tega modela v slovenskem hotelirstvu je pokazala pozitivne korelacije med vsemi pari kategorij intelektualnega kapitala. Čeprav je skupno intelektualni kapital pomembno vplival na finančno uspešnost, študija kaže, da le razmerje končnega odjemalca močno neposredno vpliva na finančno uspešnost. Študija je pokazala, da bi moral slovenski management hotelov intelektualni kapital izboljšati z naložbami v človeški kapital in informacijske tehnologije, kar je nujno potrebo pri pospešitvi procesa neposrednega razvoja distribucijskih kanalov v kategoriji odnosni kapital - končni kupec, s čimer neposredno vpliva na finančno uspešnost slovenskih hotelskih podjetij.

Med investicijami v izobraževanje posameznikov in poslovno uspešnostjo obstaja ključna povezava, zato je kakovostno izobraževanje zaposlenih še toliko pomembnejše. Čim več znanja so zaposleni posamezniki pripravljeni deliti in predstaviti svojim sodelavcem, tem močnejša vez se tvori med njimi in organizacijo. Posamezniki, ki so vpetejši v tovrstne dejavnosti, so tako uspešnejši v svoji stroki, in posledično obstaja manjša možnost, da bi zapustili svoje delovno mesto (Bontis in Serenko 2009).

Tudi Weerakoon (1996) v modelu, ki ga predlaga, navaja štirinajst značilnosti s štirih področij poslovne uspešnosti: motivacije zaposlenih, uspešnosti na trgu, produktivnosti in družbenega vpliva. Na ta način model pokriva zadovoljstvo različnih deležnikov v podjetju: strank, zaposlenih, dobaviteljev in družbe.

$\mathrm{Z}$ merjenjem uspešnosti podjetij so se ukvarjali številni avtorji:

- poslovno uspešnost podjetij lahko merimo s finančnimi kazalci (Subramanian in Nilakanta 1996), kot rast plač, ROI ali ROE;

- uspešnost podjetij lahko merimo z intelektualnim kapitalom (Sveiby 200I);

- odločilnega pomena za uspešnost organizacije je vzdušje v organizaciji (ozračje, klima) (Mihalič 2007). 
Ustvarjanje takšnega vzdušja v organizaciji pa zahteva temeljna strokovna znanja in voditeljske zmožnosti, ki jih imajo le redki managerji (Meško Štok 2009):

- za kakovostno presojo uspešnosti poslovanja denarne enote ne zadoščajo več; nedenarne niso alternativa denarnim meram, ne kažejo vrednostno izraženih historičnih podatkov, trendov, denarnih implikacij posameznih poslovnih odločitev, temveč denarne mere dopolnjujejo in kažejo vzroke denarno izraženih posledic (Ivankovič in Jerman 2010);

- povprečna letna rast števila zaposlenih $\mathrm{v}$ preteklih treh letih, povprečna letna rast prodaje $\mathrm{v}$ preteklih treh letih, rast tržnega deleža v preteklih treh letih (Auer Antončič 20 2);

- poleg motiva, ki podjetnika usmeri v rast, je v prvi vrsti ekonomski motiv, in sicer maksimiranje dobička; so pa tu še drugi razlogi za rast, npr. : (a) rast trga, ki podpira nov prostor za trženje in širitev poslovanja zaradi povečanega povpraševanja, (b) krepitev konkurence, ki podjetje sili k zaščiti in povečanju deleža s cenovno politiko, z razvojem novih izdelkov in drugimi inovativnimi strategijami, (c) karakterne značilnosti podjetnika, za katerega so značilni kreativnost, nenehno iskanje izzivov in poti do uresničitve zastavljenih ciljev, zaradi česar je pogosto pripravljen tudi na tveganja, ki spremljajo odločitev za povečanje obsega poslovanja (Tajnikar 2000);

- nekatere pozitivne posledice rasti, ki jih je strnil Orsino (1994), so: (a) rast povečuje dobičkonosnost, (b) rast zagotavlja zanesljivejši vir ponudbe in boljšo izkoriščenost distribucijskih kanalov, (c) kadar podjetje raste in prodira na nove trge, mora nastopati s ponudbo, ki je boljša od konkurenčne $-\mathrm{k}$ izboljšavam tako podjetje silijo zahteve odjemalcev na novem trgu, (č) $\mathrm{z}$ rastjo se mora podjetje truditi, da ohranja konkurenčnost na vsakem koraku (širitev ponudbe, izboljšanje izdelkov, nove tržne poti idr.), kar pa je možno le s širjenjem znanja zaposlenih in ustvarjanjem takega notranjega okolja podjetja, organizacijske klime, ki spodbudno vpliva na porajanje inovativnih idej.

Branco (2007) poudarja, da ima lahko podjetje ugledne prostore, sodobne naprave, stroje, opremo, vendar mu to ne zagotavlja kakovostnih storitev in poslovnega uspeha, saj slednje lahko doseže le na podlagi usposobljenega in kvalificiranega kadra, ki je osredotočen na poslovne dejavnosti in dosega poslovne cilje. Podjetja, ki so investirala v svoje zaposlene 
(Branco 2007), se lahko ponašajo z izboljšano kakovostjo storitev, zmanjšano odsotnostjo zaposlenih $\mathrm{z}$ dela, zmanjšanim številom odpovedi zaposlenih $\mathrm{v}$ podjetju, $\mathrm{s}$ fleksibilnostjo zaposlenih, $\mathrm{z}$ učinkovitejšim managementom sprememb, večjo produktivnostjo, $s$ povečanima dohodkom in dobičkom.

$H_{3}$ : Organizacijska klima pozitivno vpliva na uspešnost poslovanja turističnih agencij.

\section{Obrazložitev:}

Dimenzije organizacijske klime so navedene v hipotezi ena ( $\left.\mathrm{HI}_{\mathrm{I}}\right)$, uspešnost poslovanja pa $v$ hipotezi dve $\left(\mathrm{H}_{2}\right)$.

Povezanost organizacijske klime in uspešnosti poslovanja smo preverjali s pomočjo metode SEM.

Namen raziskave (Brown idr. 2014) je bil zagotoviti dodaten vpogled $\mathrm{v}$ mala turistična podjetja $\mathrm{v}$ ZDA, kjer so empirično preučevali odnos med poslovnimi/osebnimi vrednotami direktorjev, tržnimi strategijami in zaznano poslovno uspešnostjo. Osebne vrednote lahko vplivajo na izbiro tržnih strategij. Nadalje so ugotovili, da je tržno usmerjena strategija bistveno povezana $\mathrm{z}$ zaznano uspešnostjo malih turističnih podjetij (npr. zadovoljstvo kupcev in poslovni ugled). Raziskava je pomembna tudi za poslovne posledice potencialnih investitorjev $\mathrm{v}$ mala turistična podjetja $\mathrm{v}$ ZDA.

Organizacijsko klimo (Mihalič 2007, 7) opredeljujemo kot t. i. psihološko izgradnjo sistema, ki opredeljuje trenutne lastnosti organizacije in se izraža v načinu, kako njegovi pripadniki zaznavajo ta sistem. Organizacijska klima tako vsebuje mehke dimenzije osebnosti poslovnega sistema in organizacije: interakcije z ljudmi, zadovoljstvo, lojalnost, počutje pri delu, sodelovanje, solidarnost, zavest in avtonomnost. $S$ pojmom organizacijska klima opredeljujemo tiste značilnosti, po katerih se organizacija razlikuje od drugih in ki vplivajo na vedenje v njej (von Haller Gilmer in Crissy 1969). Vzporedno pa prav vedenje ljudi v največji meri vpliva na organizacijsko obliko. Dejansko je klima tisto, na kar reagiramo, je namreč celoten kontekst delovnega vrveža (von Haller Gilmer in Crissy 1969). Organizacijska klima je t. i. psihološki mehurček, ki obkroža delo (Jones in Bearley 1995) in temelji na ustvarjeni subjektivni predstavi o organizaciji, na kar pa vplivajo procesi, viri, kultura, strukture, kapital ipd. $\mathrm{V}$ tem kontekstu je klima stranski produkt delovanja 
organizacijske strukture in njenih elementov ter obenem determinanta njene učinkovitosti.

\section{Načrt raziskave}

$\mathrm{V}$ preglednici I je naveden načrt naše raziskave opisane tematike.

Preglednica I: Načrt raziskave

I. TEORETIČNA IZHODIŠČA RAZISKAVE

pregled in študij domače in tuje literature, tudi dostopnih virov s spletnih strani s področja človeškega kapitala, organizacijske klime, uspešnosti poslovanja, turizma

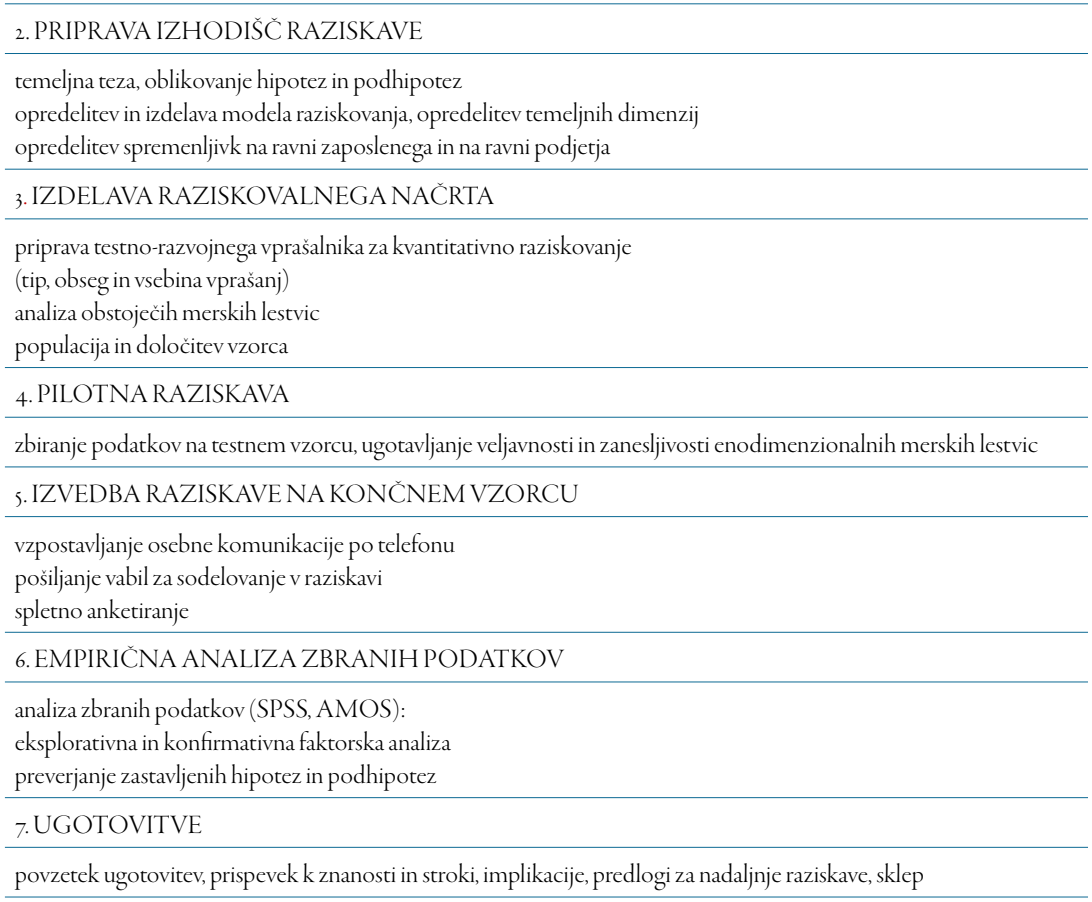

\section{Metode analize podatkov in testiranje hipotez}

Zbrane podatke bomo s pomočjo statističnih programov SPSS in AMOS obdelali in analizirali z naslednjimi statističnimi metodami:

- deskriptivno analizo;

- faktorsko analizo in metodo glavnih komponent;

- regresijsko in multiplo regresijsko analizo;

- metodami strukturnih enačb. 
Potek raziskave in uporabljene raziskovalne metode bomo podrobno opisali pri metodah analiz podatkov in testiranj hipotez.

\section{Predpostavke in omejitve pri obravnavanju raziskovalnega problema}

Raziskava temelji na naslednjih predpostavkah:

- v Sloveniji in tudi širše še ni bila izvedena nobena raziskava, ki bi ugotavljala vpliv dejavnikov človeškega kapitala in organizacijske klime na uspešnost poslovanja turističnih agencij;

- lastniki/managerji/vodje in drugi zaposleni (respondenti) turističnih agencij ter njihovih poslovalnic, ki smo jim poslali anketni vprašalnik prek spleta, so nanj odgovorili v predvidenem roku, zbrani in analizirani podatki pa odražajo resničen vpliv dejavnikov človeškega kapitala in organizacijske klime na uspešnost poslovanja turističnih agencij.

Raziskava temelji na naslednjih omejitvah:

- anketni vprašalnik je bil namenjen lastnikom/managerjem/vodjem turističnih agencij in njihovih poslovalnic ter drugim zaposlenim $\mathrm{v}$ turističnih agencijah in njihovih poslovalnicah, ne pa tudi njihovim poslovnim partnerjem, ki močno prispevajo $h$ kakovosti storitev turističnih agencij (npr. avtobusni prevozniki, hotelirji, letalski prevozniki, ponudniki gostinskih storitev itd.);

- dejavnike človeškega kapitala in organizacijske klime, ki vplivajo na uspešnost poslovanja turističnih agencij, smo preučevali z anketnim vprašalnikom, kar pomeni, da smo se zadovoljili s subjektivnimi merami respondentov;

- raziskavo smo izvedli v obdobju dveh mesecev, kar pomeni, da ni šlo za longitudinalno študijo, kar bi zagotovo povečalo veljavnost in uporabnost rezultatov;

- $\quad \mathrm{v}$ model niso vključeni vsi dejavniki človeškega kapitala in organizacijske klime, ki vplivajo na uspešnost poslovanja turističnih agencij, temveč le nekateri, s katerimi smo želeli potrditi temeljno tezo in hipoteze raziskave;

- nekateri dejavniki uspešnosti poslovanja izražajo dokaj podobna gibanja, zato smo izbrali in izračunali tiste dejavnike, ki so bili statistično najzanesljivejši. Upoštevali smo javno dostopne finančne kazalce (bizi.si), dimenzije (dejavnike) organizacijske klime pa smo preverjali v trenutku izvajanja ankete. Finančne podatke, za katere smo zaprosili le lastnike/managerje/vodje tu- 
rističnih agencij in njihovih poslovalnic, ne pa tudi drugih zaposlenih, smo potem primerjali tudi z anketnimi odgovori.

\section{Struktura raziskave}

Raziskava je sestavljena iz šestih delov, in sicer:

- $\quad \mathrm{v}$ prvem, uvodnem delu smo predstavili znanstveno področje in raziskovalni problem, namen in cilje raziskave, temeljno tezo in hipoteze, izbrane metode dela, predvidene predpostavke in omejitve pri obravnavanju raziskovalnega problema;

- v drugem, teoretičnem, delu smo opredelili človeški kapital, organizacijsko klimo in turizem;

- $\quad \mathrm{v}$ tretjem delu smo izvedli kvantitativno analizo vpliva dejavnikov uspešnosti poslovanja;

- v četrtem delu smo izvedli empirično analizo modela in testirali hipoteze z odgovori respondentov na anketni vprašalnik;

- v petem delu smo predstavili povzetek ugotovitev raziskave, prispevek k znanosti in stroki, implikacije ter predloge za nadaljnje raziskovanje;

_ v zadnjem, šestem, delu pa smo prispevali sklepne misli. 



\section{Človeški kapital}

$V$ teoretičnem delu raziskave s pomočjo izbrane domače in tuje literature ter virov opredeljujemo človeški kapital, organizacijsko klimo, turizem in $\mathrm{v}$ raziskavo vključene računovodske kazalnike, s katerimi smo preučevali uspešnost poslovanja turističnih agencij.

Pričenjamo s človeškim kapitalom. Ta skupaj s strukturnim kapitalom predstavlja intelektualni kapital podjetja, slednji pa skupaj $s$ finančnim kapitalom predstavlja tržno vrednost podjetja (Roos idr. 2000, 2I).

\section{Opredelitev človeškega kapitala}

Človeški kapital je duša podjetja. Lastniki/managerji/vodje podjetij $\mathrm{v}$ številnih primerih šele ob odhodu posameznega delavca iz podjetja zaznajo, kako pomemben del znanja (človeški kapital) je podjetje $s$ tem izgubilo. Podjetje bi moralo storiti prav vse, da bi zadržalo posamezne zaposlene, in to še preden se zaposleni odloči, da zapusti podjetje. Večji pomen bi podjetje moralo pripisati trudu, da zaposleni ostane v podjetju, in bi se moralo, če ta namerava oditi h konkurenčnemu podjetju, vprašati, kakšen je bil potem namen izobraževanja zaposlenih, kako so ravnali z njimi, kakšen je pomen investicij v izobraževanje (Roos idr. 2000). 


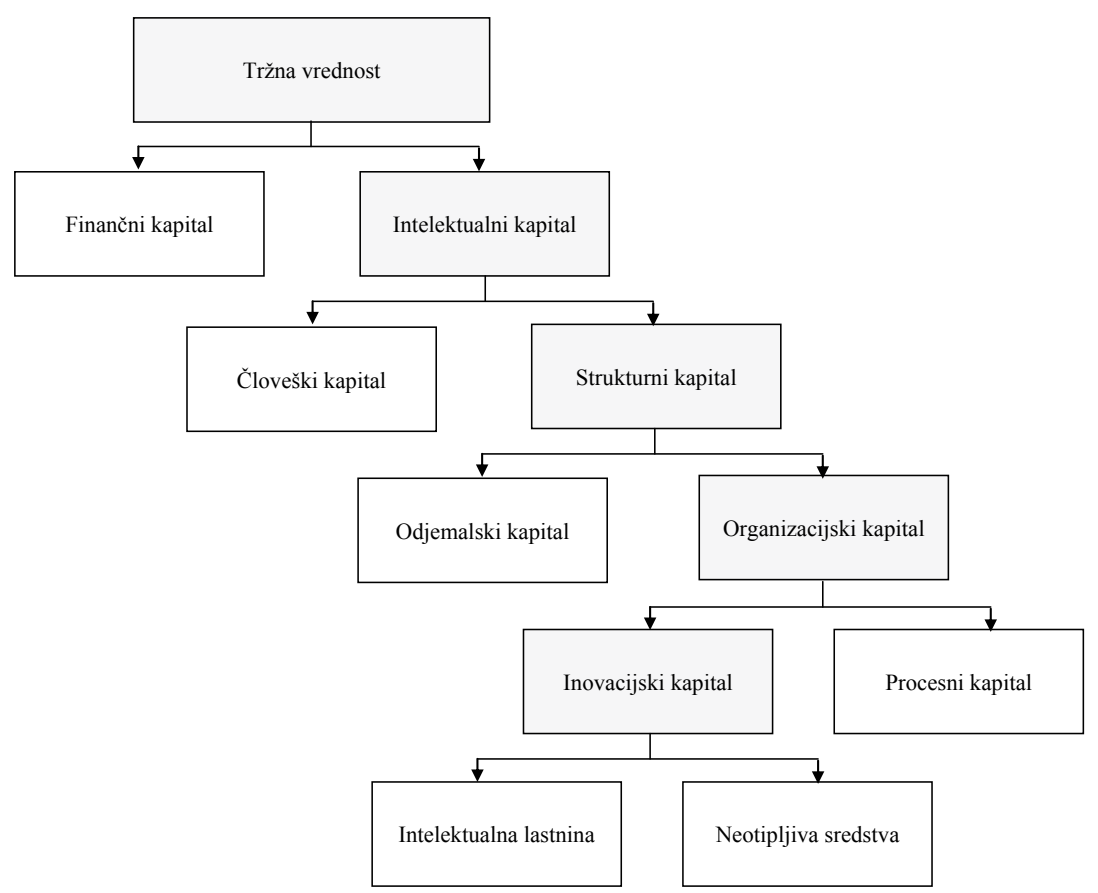

Slika 2: Skandiina vrednostna shema

Vir: Roos idr. 2000, 2 I.

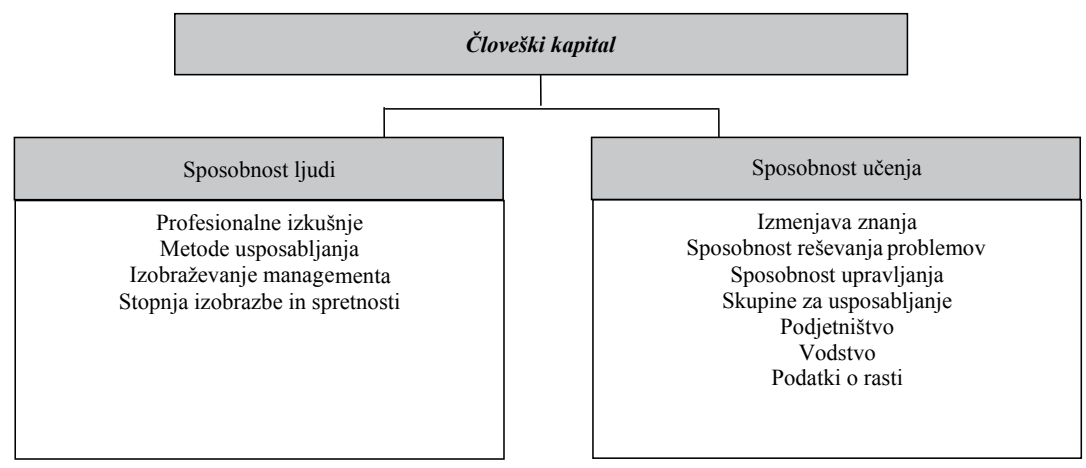

Slika 3: Človeški kapital (sposobnost ljudi in sposobnost učenja)

Vir: Petty in Guthrie 2000.

Vrednost človeškega kapitala izvira iz zmožnosti, odnosa in intelektualne prožnosti (Roos idr. 2000). 
- Iz zmožnosti zato, ker ustvarjajo vrednost z znanjem, veščinami, nadarjenostjo in $\gg$ know-howom « zaposlenih. Lahko bi celo trdili, da so zmožnosti »vsebinski« del človeškega kapitala, njegova $\gg$ strojna oprema $\ll$. V glavnem predstavljajo tisto, kar organizacija lahko stori s pomočjo svojih zaposlenih, torej njen notranji potencial. Temeljne sestavine so znanje in veščine. Znanje po tej opredelitvi pomeni tehnično ali akademsko poznavanje stvari. V glavnem je povezano $s$ človekovo stopnjo izobrazbe. Znanje je $\mathrm{v}$ bistvu nekaj, česar se moramo naučiti. Ni nujno, da ga pridobivamo v šolah ali na univerzi (tudi terensko usposabljanje je popolnoma sprejemljivo), v vsakem primeru pa se ga je treba naučiti. Znanje torej ne more biti prirojeno in se ne more nanašati na metodo učenja $\mathrm{z}$ delom ali na metodo poskusov in napak, seveda pa z njima lahko svoje znanje dopolnjujemo.

- Iz odnosa - vedenja zato, ker znanje in veščine niso vse. Podjetja potrebujejo zaposlene, ki so sposobni in pripravljeni svoja znanja in zmožnosti uporabiti v korist podjetja ter lahko celotno podjetje motivirajo za doseganje postavljenih ciljev. Odnos do dela in podjetja je torej »programska oprema «. Podjetje ima na to stran intelektualnega kapitala zelo majhen vpliv; odnos je odvisen predvsem od osebnostnih lastnosti in ga prizadevanja podjetja ne morejo kaj prida spreminjati. Nekaj pa je kljub temu mogoče storiti - ljudi spodbujati. Odnos torej pomeni vrednost, ki jo ustvarja vedenje zaposlenih na delovnem mestu. Nanj v glavnem vplivajo trije dejavniki: motivacija, vedenje in drža.

- Iz intelektualne prožnosti - pameti zato, ker je $\mathrm{v}$ svetu hitrih sprememb sposobnost uporabiti znanje $\mathrm{v}$ najrazličnejših položajih, poiskati inovativne rešitve in spremeniti zamisli v izdelke in/ ali storitve bistvenega pomena za uspeh podjetja.

N. Tomšič (2015) poudarja, da mora biti management/vodstvo podjetja vpet/-o v proces inoviranja in mora vlagati v človeški kapital, saj brez slednjega ni procesa inoviranja.

Pri opredelitvi človeškega kapitala moramo upoštevati, da so starejši avtorji uporabljali drugačno izrazoslovje. Že Adam Smith (1776) je o primeru izobraževanja delavca dejal, da mora za delo, ki ga opravlja, pričakovati višjo mezdo kot navaden delavec, vsaj za pokritje stroškov izobraževanja z običajnim profitom za enako velik kapital. To pa ni nič drugega kot to, kar trdi teorija človeškega kapitala, ki so jo koncem 5o-tih in v začetku 6o-ih let prejšnjega stoletja razvili in v primerjavi s Smithom bistveno razširili ekonomisti čikaške šole. Začetni članek je prispeval Mincer, ve- 
liko pa sta prispevala kasnejša Nobelova nagrajenca Schultz in Becker. V začetnih obdobjih uvajanja pojma človeški kapital v ekonomsko literaturo lahko zasledimo veliko nelagodnosti, kritik in celo zavračanja na strani največjih ekonomskih avtoritet svojega časa, kot sta bila npr. Marshall in Samuelson (Malačič 200I, 425).

Milost (2002) poudarja, da so za podjetja človeške zmožnosti gotovo najpomembnejše sredstvo; pogosto se namreč dogaja, da dve podjetji, ki se ukvarjata $\mathrm{z}$ enako dejavnostjo in delujeta $\mathrm{v}$ enakem okolju, dosegata zelo različne rezultate poslovanja. Razlogi za to so lahko sicer številni, vendar pa je razlika največkrat posledica različnih delovnih sposobnosti zaposlenih oz. različne kakovosti človeških zmožnosti.

$\mathrm{V}$ turistični dejavnosti je pomen človeškega kapitala odločilen za ustvarjanje vrednosti za končnega potrošnika, pri čemer so ključni pogoji zanj individualne sposobnosti in znanja delavcev, njihov odnos do dela ter inovativnost. Ustvarjanje vrednosti oz. zagotavljanje konkurenčnosti je tisto, kar loči zaposlene na tiste, ki predstavljajo človeški kapital, in tiste, ki ga ne predstavljajo, oz. določa vrednost posameznemu zaposlenemu. $S$ stališča intelektualnega kapitala vsi zaposleni za podjetje ne predstavljajo enake vrednosti, zato morajo biti drugače nagrajeni, usmerjeni in vodeni (Nemec Rudež 2006).

Schultz je leta 1960 prvi opredelil človeški kapital (angl. human capital) in vlaganja v kakovost (izobraževanje, izpopolnjevanje in usposabljanje), ki v veliki meri določajo bodočnost prebivalstva (Bevc 199i). Kakovost človeškega dejavnika, izobraževanje in razvojno-raziskovalna dejavnost bodo pripomogli $k$ družbeno-ekonomskem razvoju le, če bodo tesno povezani z okoljem in če bo ekonomski potencial (sposobnosti in znanja) ustvarjen z izobraževanjem in razvojno-raziskovalno dejavnostjo. Dva bistvena pogoja za učinkovito uporabo nekega razvojnega dejavnika sta njegova kakovost in stopnja izkoriščenosti. Ljudje vlagajo v sebe z izobraževanjem, izpopolnjevanjem, usposabljanjem in $z$ drugimi dejavnostmi ne le zaradi trenutnega zadovoljstva, ampak tudi zaradi pričakovanih donosov (povečanega bodočega dohodka s povečanimi zaslužki) teh naložb $\mathrm{v}$ prihodnosti ter drugih učinkov, ki jih ni mogoče izmeriti $\mathrm{v}$ denarju.

Prevladujoča doktrina v vzgoji in izobraževanju ima danes središče $\mathrm{v}$ teorijah o človeškem kapitalu. Te teorije, pa če so še tako polne ideoloških predsodkov, prikazujejo zelo resnično težnjo sodobnega kapitalizma po mobiliziranju čedalje številčnejših vednosti z njihovim dvojnim pogledom na produkcijske dejavnike in trgovsko blago. Ekonomisti s človeš- 
kim kapitalom označujejo »zalogo znanj«, ki jih je mogoče ekonomsko ovrednotiti in so jih posamezniki usvojili (Laval 2005, 46).

Teorija človeškega kapitala je $\mathrm{v}$ začetku nastajala na področju usposabljanja na delovnem mestu (angl. labour training). To področje so izbrali Schultz, Becker in Mincer v svojih začetnih modelih za primer investiranja v človeka. Na tem področju je tudi Becker uvedel razlikovanje med splošnim usposabljanjem in specifičnim usposabljanjem. Kasneje so se pokazale težave, saj teoriji ni uspelo razložiti, kako lahko posameznik izbira več ali manj usposabljanja na delovnem mestu. Ravno tako ji ni uspelo razlikovati med usposabljanjem, ki povzroča stroške, od usposabljanja na delovnem mestu, ki ne povzroča nobenih stroškov. Temeljni problem je v tem, da teoriji človeškega kapitala na tem področju ni uspelo oblikovati teorije poklicne izbire, ki bi jo bilo mogoče testirati. Hkrati se omejuje samo na denarne dohodke, ki jih dajejo posamezni poklici, popolnoma pa zanemarja druge privlačnosti posameznih poklicev pa tudi razne tržne in druge anomalije. Model se osredotoča le na ponudbeno stran človeškega kapitala, v celoti pa zanemarja povpraševanje na trgih delovne sile. Interne stopnje donosa, ki jih izračunavajo zagovorniki teorije človeškega kapitala, praviloma izražajo skupni donos usposabljanja na delovnem mestu in izobraževanja. Becker (1964) je že v svoji monografiji Human Capital zapisal, da lahko zelo velik porast zajetja v srednjih in visokih šolah razložimo $\mathrm{z}$ visokim donosom investiranja $\mathrm{v}$ to vrsto izobraževanja.

Človeški kapital je gonilna sila intelektualnega kapitala. Nanaša se na akumuliranje vrednosti investicij $\mathrm{v}$ izobraževanje, strokovnost in bodočnost vseh zaposlenih in management ter njihove sposobnosti, da svoje znanje, veščine in izkušnje (kot rezultat navedenih investicij) preoblikujejo v dejavno ustvarjanje dodane vrednosti za podjetje (Sundać in Švast 2009).

Ulrich (1998) trdi, da se človeški (managerski) kapital na individualni ravni lahko meri s pomočjo kompetenc. Kovač in Bertoncelj (2007) sta z modelom managerskih kompetenc ugotovila, da se del kompetenc spreminja in jih je mogoče pridobiti ali se jih naučiti (vedenjske in kognitivne kompetence), medtem ko jih je del prirojenih in zato nespremenljivih (konativne kompetence).

Med človeške sposobnosti uvrščamo predvsem (Nemec 2005, 54): psihomotorične (ročna spretnost, okretnost, hitrost, reaktivnost; te spretnosti se izostrijo z intenzivnimi vajami), čutne (vid, sluh, tip, vonj, čut za ravnotežje ipd; nekateri ljudje imajo boljši vid kot drugi, enako velja za sluh; čutne sposobnosti so odvisne tudi od življenjskega obdobja), mentalne in intelektualne (spomin, inteligentnost, ki ga kaže inteligenčni ko- 
ličnik (IQ), kreativnost, hitrost zaznavanja, talentiranost oz. nadarjenost; verbalna, oblikovalna, tehnična, glasbena ipd.).

A. Brezovec (2000) poudarja, da zaradi človeškega dejavnika storitve ne morejo biti vsakič opravljene na enak način. Pravimo, da so turistične storitve heterogene (neenake). Zaposleni in turisti s svojimi željami, potrebami in pričakovanji povzročajo, da se storitve od primera do primera razlikujejo. Prav zaradi osrednje vloge človeškega dejavnika storitev ni mogoče popolnoma standardizirati.

\section{Intelektualni kapital}

Pred navedbo temeljnih opredelitev intelektualnega kapitala je smiselno poudariti, da intelektualni kapital vključuje veliko več kot kateri koli drugi izraz, ki ga ponuja literatura ali praksa s tega področja (Roos idr. 2000).

Po klasični teoriji ločimo pozitivno in negativno opredelitev intelektualnega kapitala, ki predstavlja osnovo opredeljevanja področja. Po prvotni, t. i. pozitivni opredelitvi je intelektualni kapital podjetja opredeljen kot vsota znanja vseh zaposlenih in praktične uporabe tega znanja, in sicer zaščitnih znakov, blagovnih znamk ter procesov (Roos idr. 2000), po negativni opredelitvi pa je intelektualni kapital vse v podjetju, kar lahko ustvarja vrednost in je neotipljivo. Ta opredelitev intelektualni kapital opredeljuje kot razliko med skupno oz. celotno vrednostjo podjetja, torej tržno vrednostjo, in njegovo finančno vrednostjo, torej knjigovodsko vrednostjo (Roos idr. 2000).

Intelektualni kapital danes številni avtorji najpogosteje opredeljujejo kot neopredmeteno in skrito vrednost organizacije, ki ustvarja vrednost (Sveiby 200I). Vendar kljub neotipljivosti in neopredmetenosti ne gre za skrito vrednost, saj se v podjetju odraža in jo je mogoče izmeriti. Intelektualni kapital lahko namreč ustvari nov intelektualni kapital v drugi obliki ali npr. finančni kapital. Po eni izmed tovrstnih opredelitev je intelektualni kapital največkrat nezabeležena vrednost, ki je ponavadi ne moremo poiskati v finančnih zapisih, edini vidni primeri intelektualnega kapitala pa so lahko blagovne znamke, avtorske pravice, znanje zaposlenih, zaščitne znamke, raziskave, razvoj in podobno (Buckley 2000). Po prav tako izpeljani opredelitvi predstavlja premoženje intelektualnega kapitala vse nefinančne vire organizacije (Chatzkel 1998). Po še eni izmed tovrstnih opredelitev pa je intelektualni kapital neopredmetena korporativna vrednost, ki ima ključno vlogo $\mathrm{v}$ današnjih sistemih za ustvarjanje vrednosti organizacij, in sicer tako $\mathrm{v}$ klasičnih poslovnih okoljih kot $\mathrm{v}$ neprofitnih organizacijah (Daum 2003). 
Intelektualni kapital podjetja izvira predvsem iz sposobnosti zaposlenih, da ustvarjajo vrednosti, ki jih valorizira trg, pri čemer izdatki za zaposlene, vključno s plačami in z drugimi odhodki, niso pojmovani kot stroški v poslovanju; zaposleni namreč investirajo v svoje znanje in sposobnosti, rezultat tega pa je ustvarjena dodana vrednost, potrjena na trgu (Pulić 2003). Glede na osnovno strukturo je intelektualni kapital opredeljen kot premoženje v ljudeh, povezavah in organiziranosti, ki ustvarja novo vrednost (Roos idr. 2000). Na tej osnovi je intelektualni kapital kompleksen sistem človeškega, procesnega in relacijskega kapitala podjetja (Chatzkel 1998).

Strokovno znanje in intelektualne sposobnosti so pomembni za uspeh podjetja (Carnegie 20I2). Pomembni pa so tudi znanje in izkušnje ter seveda tudi okolje, od koder so posamezniki te izkušnje pridobili. Pomembna je teorija, vendar tudi njena uporaba v praksi.

Skandia tržno vrednost deli na finančni in intelektualni kapital. Intelektualni kapital razdeli na strukturni kapital, torej na tisto, kar v podjetju ostane, ko ljudje - zaposleni odidejo domov, npr. zaščitne znake, blagovne znamke, zapisane postopke procesov, in na človeški kapital (vse, kar misli). Strukturni kapital vključuje odjemalski in organizacijski kapital, pri čemer je odjemalski kapital zunanji, organizacijski pa notranji. Organizacijski kapital je sestavljen iz inovacijskega in procesnega kapitala. Procesni kapital je vsota znanja, ki je formalizirano v podjetju, kot npr. priročniki, najuspešnejši postopki, sredstva, povezana z intranetom, knjižnice. Inovacijski kapital je tisto, kar ustvarja prihodnji uspeh - je vir obnavljanja celotnega podjetja ter vključuje intelektualna sredstva in intelektualno lastnino (Roos idr. 2000).

Intelektualni kapital razdelimo na strukturni in človeški kapital. Ta parametra predstavljata nekaj, kar imenujemo nevidna sredstva (in procese) in znanje, utelešeno v zaposlenih. Z ljudmi, se pravi s človeškim kapitalom, je treba pri delu ravnati popolnoma drugače kot $s$ strukturnim kapitalom. Slednji izhaja iz odnosov in organizacijske vrednosti ter zrcali zunanje in notranje vidike podjetja, poleg tega pa še obnovitveno in razvojno vrednost, torej prihodnji potencial. Vrednost lahko ustvarjajo vsi (dobri) odnosi z drugimi udeleženci v okolju, ki turistične deležnike obdaja, to je z odjemalci, dobavitelji in s partnerji. Tudi sistemske spremenljivke, ki podjetju pomagajo opravljati vsakodnevno delo, npr. rutine in procesi, lahko ustvarjajo znatno vrednost. Ljudje v podjetju ustvarjajo kapital s svojimi zmožnostmi, odnosom in intelektualno prožnostjo. Zmožnosti vključujejo veščine in izobrazbo, odnos pa pomeni vedenjski vidik dela zaposlenega. Intelektualna prožnost je sposobnost inovativne- 
ga razmišljanja in uvajanja sprememb, razmišljanja o problemih ter iskanja inovativnih rešitev. Razlikovanje med intelektualno prožnostjo ter zmožnostmi in vedenjem temelji na dejstvu, da intelektualna prožnost ni niti veščina niti vedenjski vzorec, temveč kombinacija obojega (Roos idr. 2000).

\section{Izobraževanje, učenje in znanje}

Sleherno znanje vsebuje vsa druga znanja, ki so se vanj integrirala, še preden smo ga dali od sebe, in vsebuje vsa tista znanja, ki se bodo vanj še integrirala v prihodnje. Ljudje povečamo svoje znanje tako, da skupaj delamo. Znanje je namreč neizčrpen vir, ki ga je nemalokrat moč izkoriščati povsem brezplačno. Eksternalija pomeni, da nekateri posamezniki, podjetja, regije ali države lahko uporabljajo neko dobrino, ne da bi jih ta kaj stala. V tem primeru dobrina obstaja v okolju ali jo je proizvedel nekdo drug, in sicer v druge namene, pa je prišlo do nekakšne pomnožitve njene uporabe neodvisno od tega, čemu je bila sprva namenjena. Znanje je namreč moč uporabiti na mnogotere načine in je torej pogost vir, v nasprotju s stvarnimi viri, ki veljajo za redke. Znanje je eno glavnih gibal današnje ekonomije. Proizvajalci danes tekmujejo tako, da zmanjšujejo stroške in/ali izboljšujejo izdelke (storitve) za kupce, ki so že tako zasičeni z nestvarnimi dobrinami. Podjetja so konkurenčna, če so prepoznavna, drugačna. Človeški kapital je težko pridobiti in znati je treba sodelovati z ljudmi, ki ta kapital imajo (Findeisen 2004).

Učeči naj bi bil zmožen samostojno opravljati dejavnosti in sprejemati odločitve v zvezi z učenjem, to je (Jelenc 1998): pripraviti učenje (izrabiti cilje, razjasniti njihov pomen, se motivirati in se začeti učiti), izpeljati dejavnosti, povezane z učenjem (potrebne za zapomnitev, razumevanje, povezovanje, uporabo znanja), uravnati učne dejavnosti (preverjati, ali so uspešne; popravljati, če niso), ovrednotiti dosežke (dati si povratno informacijo, ali je bil proces učenja dober, ali so dosežki taki, kot sem želel/-a) in vzdrževati potrebno motivacijo in zbranost.

Učenje je $\mathrm{v}$ primerjavi z izobraževanjem kompleksnejši pojem. Ne moremo ga očistiti niti čustvenih niti vrednostnih sestavin. Izobraževanje je bilo vseh teh komponent očiščeno vsaj v pomenu, ki mu ga pripisujejo njegovi načrtovalci, ko ga določijo s kognitivnimi cilji. Samo s pojmom izobraževanje ne moremo pojasniti vseh učinkov učenja.

Hudson (1993) poudarja, da je treba razumeti, da bistvo znanja ni v knjigah, ampak v mislih posameznikov.

Posameznik se mora nenehno učiti, sprejemati spremembe in se prilagoditi novim zahtevam ter potrebam delovnega mesta ter družbe kot 
celote. Učenje je tako za načrtovanje kariere izjemno pomembno. $\mathrm{Na}$ tej podmeni temeljijo teorije učenja, po katerih je razvoj kariere odvisen predvsem od posameznikovega učenja.

Po Stonehousu in Pembertonu (1999) je kognicija opredeljena kot zmožnost posameznika za učenje in prilagajanje okolju. Kognitivne zmožnosti so sposobnosti posameznika za pridobivanje, hranjenje, manipulacijo, analizo in interpretacijo informacij, ki se v končni fazi kažejo kot časovno ustrezne odločitve. Posameznik z dobro razvito zmožnostjo kognicije je svojo usklajenost z zunanjim okoljem (tj. posameznik zmore doseči cilje, ki so cenjeni v družbeno-kulturnem okolju, kjer deluje) sposoben povečati $z$ asimilacijo (usvojitvijo) novih informacij ali akomodacijo (prilagoditvijo) svojih obstoječih miselnih modelov. $\mathrm{V}$ procesu kognitivnega razvoja spreminja oz. dopolnjuje svoje miselne modele, kar mu v splošnem omogoča, da se laže prilagaja različnim okoliščinam (premore več raznovrstnosti), deluje zanesljiveje oz. predvidljiveje in je na splošno robustnejši ob vse več spremembah v svojem okolju.

J. S. Eccles in Wigfield (2002) navajata, da imajo posamezniki, ki so $\mathrm{v}$ svojem procesu učenja in doseganju zastavljenih ciljev zelo dejavni, naslednje značilnosti:

- verjamejo, da morajo sami poskrbeti za doseganje lastnih ciljev in da ne morejo biti odvisni od tuje volje ali od dejavnosti, ki jih izvaja nekdo drug;

- verjamejo, da lahko sami dovolj učinkovito dosežejo zastavljene cilje;

- za doseganje cilja uporabljajo različne vedenjske strategije in te prilagajajo glede na okoliščine, v katerih delujejo.

Avtorja pri raziskavi s področja motivacije, prepričanj, vrednot in ciljev, velik pomen pripisujeta teoriji osredotočanja na pričakovanja za uspeh, teoriji, ki se osredotoča na delovne vrednosti, teoriji, ki vključuje pričakovanja in vrednote, ter teoriji, ki vključuje motivacijo in spoznanja.

Izobraževanje je splošen pojem in se ne nanaša na konkretno izobrazbo, ki jo izobraževalec pridobi v tej ali oni šoli s študijem določene literature in podobno. Nanaša se na proces posredovanja in usvajanja določenega znanja, ki predstavlja v kak sistem vgrajene resnice in spoznanja; ko vrednotimo izobraževanje, vrednotimo resnice in spoznanja. Tradicionalno sta izobraževanje in vzgajanje večkrat obravnavana kot priprava za življenje, danes pa že pravimo, da je izobraževanje v mladosti le priprava za permanentno izobraževanje. Na splošno izobraževanje definiramo kot proces pridobivanja znanja in formiranja spretnosti ter navad, kar naj 
končno privede tudi do oblikovanja pogleda na svet. Oba procesa, proces izobraževanja in proces vzgajanja, sta neločljivo povezana. Kot družbeno pogojeno in usmerjeno dejavnost ju označujeta predvsem dve značilnosti: internacionalnost in sistematičnost. Zaradi tega izobraževanje ni kakršno koli, ampak le sistematično pridobivanje znanja. $Z$ njim se usvaja in prenaša znanje z raznih področij znanosti in umetnosti. Sistem znanja bo v vsakem konkretnem primeru drugačen, odvisen bo predvsem od številnih družbenih možnosti in individualnih dejavnikov. Rezultat izobraževanja naj ne bo le sistem znanja, temveč naj izobraževanje razvija tudi različne navade in spretnosti. To je sočasno tudi proces usposabljanja osebnosti, da bo usvojeno znanje lahko uporabljala v vsakdanji življenjski praksi. Uporaba pridobljenega znanja je v izobraževanju končna faza učenja, brez nje je vzgojni proces nepopoln - to je končno merilo vrednotenja rezultatov (Krajnc 1997, 27).

Različne vrste otipljivega znanja (Dimovski idr. 2005) se prenašajo na tri načine: za shranjevanje in prenos znanja je najpomembnejši osrednji elektronski dokumentacijski sistem, v katerem so dokumentirani vsi koraki pri razvoju in proizvodnji posameznega proizvoda. Sistem je zavarovan, dostop do dokumentov v njem pa omejen. Drugi način so deljeni dis$\mathrm{ki}$, na katere zaposleni shranjujejo dokumentacijo in predstavitve, do njih pa imajo neomejen dostop sodelavci v posamezni poslovni funkciji; tretji način prenosa znanja je elektronska pošta.

\section{Kompetence vizobraževanju}

Številni delodajalci neposredno občutijo potrebo po kompetentnih sodelavcih, ki so $\mathrm{v}$ spremenljivih razmerah sposobni učinkovito reševati nevsakdanje naloge. Različne tehnologije in številne delovne naloge od zaposlenih zahtevajo vrsto delovno specifičnih kompetenc, seveda pa so ključnega pomena tudi splošnejše kompetence, ki so potrebne za uspešno reševanje težav v zasebnem in javnem življenju ter tudi pri delu (Svetlik idr. 2005).

Dejavnosti na področju ravnanja z ljudmi pri delu se začnejo z vstopom posameznika $v$ organizacijo in se nadaljujejo skozi vso njegovo kariero, ne glede na to, katero delovno mesto zaseda (Svetlik idr. 2005).

Izvajalci dela, ki vplivajo na kakovost izdelkov, morajo biti kompetentni na podlagi izobrazbe, usposobljenosti, veščin in izkušenj. Organizacija mora (Brečko 2005):

- določiti potrebno kompetentnost izvajalcev dela, ki vplivajo na kakovost izdelkov; 
- zagotoviti ustrezno usposabljanje ali izvesti druge ukrepe za zadovoljevanje teh potreb;

- oceniti učinkovitost izvedenih ukrepov;

- zagotoviti, da se zaposleni zavedajo pomena svojih dejavnosti in tega, kako lahko pripomorejo $\mathrm{k}$ doseganju ciljev kakovosti;

- vzdrževati primerne zapise o izobrazbi, usposabljanju, veščinah in izkušnjah.

Dejavniki, ki jih zaposleni pričakujejo na delovnem mestu (Carnegie 2013), so naslednji: delo mora biti deležno potrditev in biti cenjeno, delo mora spodbujati in zadovoljevati, poklicna pot mora biti odprta in obstajati morajo možnosti za razvoj, vodje morajo spoštovati uravnoteženo življenje, ustrezno plačilo in nadomestila.

\section{Učinki izobraževanja in njihovo merjenje}

Pri učinkih izobraževanja gre za vse tiste implikacije, ki jih ustvarja izobraževanje. $V$ številnih primerih gre za dolgoročne investicije v izobraževanje, ki predstavljajo tako časovno kot tudi finančno dimenzijo. Pri vsakem izobraževanju pa ne moremo in tudi ni enostavno ugotavljati, meriti, kakšen je indeks »produktivnosti $\ll$.

Eno od vprašanj ekonomike izobraževanja je tudi ugotavljanje oz. merjenje učinkovitosti (produktivnosti) izobraževanja. Cilji oz. naloge izobraževanja niso le usposabljanja za delovne funkcije, temveč tudi usposabljanje in vzgajanje človeka za vrsto njegovih funkcij (Černetič 2006), npr. občana, državljana, družinskega očeta itd. Dalje: pri vprašanju merjenja produktivnosti (učinkovitosti) izobraževanja je treba ugotoviti, da je izobraževanje proces, $\mathrm{v}$ katerem učenec in učitelj prispevata $\mathrm{k}$ obsegu in $\mathrm{h}$ kakovosti »proizvoda $\ll$.

Pastuović (1999) je pri preučevanju ekonomskega vrednotenja izobraževanja (predvsem izobraževanja ob delu) oblikoval dve metodi (tehniki) merjena učinkovitosti, in sicer t. i.:

- diagnostično učinkovitost izobraževanja in

- funkcionalno učinkovitost izobraževanja.

Metodi (tehniki) se sicer med seboj ne izključujeta, vendar po avtorjevem mnenju s prvo predvsem želimo ugotoviti stopnjo »usvajanja « programirane vsebine izobraževanja (npr. s preizkusi znanja, $\mathrm{z}$ »izpraševanjem«, izpiti ipd.). Ugotavljamo oz. preverjamo torej pridobljeno znanje posameznih udeležencev izobraževanja. 
Diagnostična učinkovitost izobraževanja nam ne pove ničesar o individualnih razlikah pri uporabi pridobljenega znanja v procesu dela oz. nam ne nudi elementov za ekonomsko vrednotenje količine vloženih (porabljenih) sredstev v odnosu do ekonomskih učinkov procesa dela (zvišanje individualne produktivnosti). Skratka - pri tej metodi ne gre za ekonomsko vrednotenje »dodane vrednosti $\ll$, ki so si jo udeleženci določene izobraževalne oblike pridobili v procesu »proizvodnje « v šoli (ali tečaju, seminarju), glede na predhodno raven (obseg in kakovost) znanja. To dodatno vrednost skuša ovrednotiti druga metoda.

$\mathrm{Za}$ funkcionalno metodo ugotavljanja učinkovitosti izobraževanja je značilno, da z njo predvsem želimo ugotavljati ekonomske učinke izobraževanja prek merjenja (ugotavljanja) višje produktivnosti, delovne uspešnosti, hitrejšega prilagajanja novi tehnologiji itd. posameznikov in skupin, ki so zaključili, »konzumirali« določeno izobraževanje. Pri funkcionalnem vrednotenju so po Pastuoviću (1999) možni trije pristopi: sukcesivni, eksperimentalni in komparativni.

\section{Izobraževanje v podjetjih in njegova učinkovitost}

Nekateri avtorji, ki so preučevali vpliv izobraževanja na ekonomski razvoj, so se v svojih raziskovanjih oprli na zvišanje individualne produktivnosti dela pod vplivom izobrazbe.

Ekonomski učinki vlaganj $\mathrm{v}$ izobrazbo se kažejo tudi v (Černetič 2006, 20):

- zniževanju proizvodne cene izdelkov prek zvišanja produktivnosti, tj. v preseganju proizvodnih norm, manjšem izmetu, višji kakovosti itd.;

- zmanjšanju števila nesreč pri delu;

- hitrosti vračanja vloženih sredstev za izobraževanje;

- višji produktivnosti zaposlenih itd.

Becker (1964) poudarja, da usposabljanje v podjetjih lahko poveča trenutne izdatke, vendar je zanj značilno, da je dobičkonosno; gre za to, da mora biti neto sedanja vrednost investicije $\mathrm{v}$ delovno usposabljanje dobičkonosna.

Za kompetence posameznika je značilno, da jih spoznamo šele pri njegovem vsakodnevnem delovanju v različnih delovnih in življenjskih okoliščinah. Pri tem se ljudje med seboj razlikujejo. Vsakdo se v različnih življenjskih situacijah odziva drugače, se obnaša drugače, je drugačen (Ivanuša-Bezjak 2006, 45). 
Rast in razvoj človeškega kapitala se lahko izraža v povečanju uspešnosti posameznikov in organizacije, in sicer po naslednjih kazalnikih/vidikih uspešnosti (Starc in Ilič 2007, 62): kakovosti zdravstvenih storitev, učinkovitejši organizaciji dela, zadovoljstvu zaposlenih, širjenju zdravstvene dejavnosti in izboljševanju sposobnosti zaposlenih, pripadnosti organizaciji, produktivnosti na delovnem mestu, kakovosti medsebojnih odnosov, prilagajanju spremenjenim pogojem dela, lažjem in hitrejšem sprejemanju nove tehnologije, doseganju optimalnega izkoristka uporabljenih virov, učinkovitejšem izkoristku materiala in učinkovitejšem izkoristku delovnega časa.

Izkoriščenje znanja $\mathrm{v}$ podjetjih ima pomembno vlogo, saj nam znanje, ki ga imamo, prav nič ne koristi (Roos idr. 2000, I3), če ga ne moremo uporabiti pri poslovanju podjetja. Aplikacija znanja je prvi in najpomembnejši cilj slehernega komercialnega prizadevanja, ker ustvarja vrednost iz znanja, nakopičenega v podjetju, in (po možnosti) izboljšuje finančni položaj podjetja. Aplikacija ustvarja tudi $\gg k n o w-h o w \ll$, torej praktično znanje in veščine o tem, kako uporabiti teoretična spoznanja, strokovne ukrepe in praktične rešitve.

$\mathrm{V}$ podjetjih najpogosteje izvajajo krajša, $s$ stroko povezana usposabljanja. Izvajalci so večinoma notranji, npr. trenerji ipd., ponekod oz. za določene teme pa vključujejo tudi zunanje - npr. dobavitelje. Za krajša, standardna, usposabljanja (Dermol 20IO, I47) v večjih podjetjih obstajajo katalogi, ki nastajajo na osnovi letnih načrtov. Nekatera podjetja podpirajo in financirajo vključevanje svojih zaposlenih $\mathrm{v}$ formalne oblike izobraževanja - to velja predvsem za večja podjetja. V njih svoje kadre do določene mere celo načrtno spodbujajo $k$ vpisu v primerne oblike izobraževanja.

Za organizacije, ki se spreminjajo vsak dan, tradicionalne metode izobraževanja niso več dovolj. Za učeče se organizacije je najbolje, da izobraževanje poteka kar na delovnem mestu, kadar gre za znanje, ki ga potrebujemo za izvajanje določenih nalog. Kadar gre za vsebine, pri katerih je pomembna medsebojna interakcija (Brečko 2006, 22 I), je smiselno vpeljati izobraževanje v skupinah (notranjih ali zunanjih). Tudi managerji in vodstveni delavci morajo znanje nenehno dopolnjevati z novimi in primernejšimi učnimi pristopi in metodami. Prav tako, kot se od timov v učeči se organizaciji pričakuje, da bodo samostojno reševali notranje težave, mora biti učeča se organizacija sposobna pospešiti procese lastnega učenja in razvoja. 
M. Ivanuša-Bezjak (1996) poudarja, da sta čas in konkurenca pomembni dimenziji, ki jima morajo slediti podjetja in zaposleni, saj potrebe po novem znanju izraža tudi sodobni trg.

Posameznik v svoj človeški kapital investira zaradi različnih razlogov, med najpomembnejše pa lahko štejemo bodoče donose, ki jih izobraževanje prinaša posamezniku in družbi kot celoti. $V$ številnih primerih učinkov izobraževanja v človeški kapital ne moremo neposredno meriti, saj se znanje $\mathrm{v}$ posamezniku akumulira in šele čez čas lahko prodaja svoje znanje na trgu po določeni ceni, kar mu prinaša določeno korist in hkrati tudi zadovoljstvo. V zadnjem obdobju investicija v človeški kapital za številne posameznike predstavlja tudi konkurenčno prednost na trgu in številna podjetja se že zavedajo, kakšen pomen je treba pripisati posameznikom, ki s svojimi znanjem, sposobnostmi in tudi veščinami prinašajo dodano vrednost podjetju (Kaluža 2013b).

Za podjetja je pomembno, da se lastniki, managerji in vodje ukvarjajo z mentoriranjem, ki je dolgoročen proces in vključuje svetovanje ter širi karierni razvoj posameznika. Različni mentorji k svoji vlogi pristopajo različno, nekateri svoje varovance bolj varujejo, medtem ko jih drugi postavljajo pred različne izzive (Dimovski idr. 2013).

Rezultati drugih raziskav (merjenja učinkov izobrazbe na produktivnost) vodijo do naslednjih ugotovitev (Černetič 2006, 20):

- vlaganja v izobrazbo pod določenimi pogoji (tehnično-tehnološkim in organizacijskim pogojem prilagojeno izobraževanje) predstavljajo eno najučinkovitejših naložb organizacij;

- izobraževanje ob delu in za delo je (ob predpostavki dodatnih znanj in usposobljenosti) ekonomsko najučinkovitejši način zviševanja produktivnosti dela;

- možnost, da se prek izobraževanja ob delu dosegajo večji individualni proizvodni (in materialni) učinki, predstavlja močan motivacijski dejavnik za stalno (permanentno) izobraževanje;

- z izobraževanjem vplivamo tudi na kakovost vrste ekonomskih odločitev, $\mathrm{v}$ katere so $\mathrm{v}$ naših razmerah vključeni delavci - kot upravljavci ali kot lastniki (upravljavska pravica iz dela ali kapitala).

Kožuh in Vogrinc (2009) poudarjata, da za podjetja ni tako pomembna količina informacij za ustvarjanje znanja, pomembnejši je pomenski del, ki prenaša vsebino. Tok informacij je po njunem pravzaprav tok sporočil, ki ob določenem smotrnem povezovanju in prepričanju ustvarjajo novo znanje. 
Podjetje mora za uspešno oblikovanje in delitev znanja ustvariti primerno organizacijsko okolje, ki bo podpiralo ustvarjanje znanja. Prednosti, ki jih prinaša delitev znanja, se kažejo navzven v večji konkurenčni prednosti podjetja in navznoter $\mathrm{v}$ bolj izobraženem in usposobljenem kadru, ki predstavlja največje bogastvo ter najpomembnejše sredstvo podjetja, to je intelektualni kapital.

Za oblikovanje ustreznega organizacijskega okolja je treba v organizaciji, ki ustvarja znanje, zadostiti naslednjim pogojem (Muc 2003, 40): oblikovati vizijo znanja, razviti ekipo znanja, zgraditi visoko zahtevno področje interakcij med zaposlenimi, $\mathrm{v}$ razvojnem procesu prenesti znanje na nove izdelke ali storitve, preiti k povezovanju organizacije, zgraditi mrežo znanja z zunanjim svetom.

Spremljanje učinkovitosti izobraževanja je pomembno tudi za podjetja. Zaposleni so najpomembnejše premoženje podjetja, najdragocenejši vir idej in eden ključnih temeljev za konkurenčno prednost podjetja. Glede na vsebinske značilnosti izobraževalnih dejavnosti je kazalce smiselno združiti v naslednje tematske sklope (Rejc 200I, II7): produktivnost, stroški, čas, kakovost in zadovoljstvo. Zadovoljstvo zaposlenih vpliva na njihovo produktivnost, ustvarjalnost, absentizem, fluktuacijo in pripadnost podjetju.

Izobraževanje je strokovno vodeno in nadzorovano. Pri tem je izredno pomembno njegovo načrtovanje, pri čemer se določajo viri potreb po izobraževanju, ki so odvisni (Pureber 200I, I20) od letnih osebnih razgovorov, posameznikove usposobljenosti in predvidenega načrta napredka, politike in ciljev podjetja.

Ključne faze oz. elementi usposabljanja kadrov so (Miglič in Vukovič 2006, 187): izbira teme usposabljanja, določitev ciljev, spodbujanje ustvarjalnega mišljenja, postavitev parametrov, odobritev naloge in izdaja pooblastila, pregled (povzetek).

Področje izobraževanja v podjetju je izredno obsežno, saj zajema naslednje sklope (Pureber 200I, I20):

- področje managementa: programi, namenjeni vodstvu podjetja, vodjem $\mathrm{v}$ terciarnih dejavnostih in vodjem $\mathrm{v}$ proizvodnji;

- področje kakovosti: programi, namenjeni zagotavljanju kakovosti oz. usvajanju novih načinov za zagotavljanje kakovosti;

- področje tehničnega izobraževanja: programi, vezani na proces in opremo;

- področje strokovnosti zaposlenih: programi, namenjeni pridobivanju znanja in veščin s področij komuniciranja, obvladovanja 
stresa, pedagogike, retorike, spodbujanja kreativnosti, treningov samozavesti;

- področje tujih jezikov: funkcionalno-komunikacijska metoda, samostojno učenje ob pomoči mentorja, samostojno učenje v skupini;

- področje računalništva: izvajanje programov za uporabo standardnih računalniških programov v podjetju;

- področje študija ob delu, prakse in praktičnega pouka omogoča izboljšanje kvalifikacijske strukture zaposlenih;

- področje izobraževanja proizvodnih delavcev.

Za uspešna podjetja je značilno (Planko 20oI), da se zavedajo pomena nenehnega in ustreznega usposabljanja zaposlenih in tudi skrbi za njihov profesionalni razvoj. Intelektualni kapital je tisto, s čimer se ukvarjajo številna podjetja, ki želijo biti na trgu uspešnejša. Za nova znanja je značilno, da morajo biti v podjetju racionalno organizirana in dostopna, učinke usposabljanj pa je treba spremljati in vrednotiti.

Sredstva, ki jih podjetja vlagajo v izobraževanje in usposabljanje zaposlenih, namreč niso zanemarljiva in predstavljajo pomembno finančno naložbo. Ta pa ni učinkovita, če zaposleni pridobljenih znanj in veščin pri svojem delu ne uporabljajo oz. če ta znanja ne vplivajo na njihovo razmišljanje in vedenje. Za cilj vlaganj v usposabljanje zaposlenih je pomembno, da postane neposredna naložba $\mathrm{z}$ učinki za poslovno uspešnost podjetja. Za podjetja je pomembno ciljno usposabljanje in pridobivanje znanj zaposlenih, torej znanj, ki jih lahko pri svojem delu neposredno uporabijo in tako izboljšajo kakovost svojega dela. Tako postanejo vlaganja $\mathrm{v}$ usposabljanje zaposlenih neposredna naložba $\mathrm{z}$ učinki, ki se odražajo v poslovni uspešnosti podjetja (Planko 20or). Splošno znani sta mnenji, da je pomembno in obvladljivo le tisto, kar je tudi merljivo, ter da so zaposleni najpomembnejši in ključni del podjetja. Izjavi si do določene mere nasprotujeta, saj so ravno »mehke« dimenzije dela v podjetju težko merljive. $Z$ razvijanjem novih metod in pristopov ter njihovim uvajanjem $\mathrm{v}$ podjetju pa lahko obe načeli povežemo. Tako lahko začnemo vrednotiti tudi naložbe $\mathrm{v}$ razvoj zaposlenih in $\mathrm{v}$ njihov učinek, kar pa posredno pomeni tudi boljše obvladovanje razvoja zaposlenih v podjetju.

Znanje zaposlenih predstavlja intelektualni kapital, slednjega delimo na individualnega in skupinskega. $\mathrm{V}$ povezavi $\mathrm{z}$ drugimi pojavnimi oblikami finančnega kapitala intelektualni kapital v primernem okolju omogoča izjemne razvojne dosežke. Skoraj vsi se verjetno strinjamo, da je znanje zaposlenih odločujoča komponenta za gospodarski, znanstveni in kulturni razvoj družbe. Zaposleni v določeni družbi imajo lahko zelo 
veliko znanja, vendar pa okolje v tej družbi ne zagotavlja optimalnih pogojev, da se znanje prelije $\mathrm{v}$ dodano vrednost bodisi $\mathrm{v}$ obliki novih proizvodov bodisi storitev na tržišču (Nemec 2002). Znanje je intelektualni kapital, zato ima kot vsak drugi kapital na trgu tudi svojo ceno, ob predpostavki, da trg za tovrsten kapital sploh obstaja.

Za temeljne veščine poslovnega pogovarjanja ni dovolj samo naravna nadarjenost. Poleg tega potrebujemo še znanje o osnovah komuniciranja in veščine, ki si jih pridobimo z izkušnjami in vajo. Na nadarjenost ne moremo bistveno vplivati, saj je v veliki meri prirojena - posameznik jo ima ali je nima. Ustrezno znanje si pridobimo s strokovnim izobraževanjem, veščine pa z izkušnjami in s treningom (Mihaljčič 2006, 67).

Stewart (I99I), urednik časopisa Fortune, je objavil članek z naslovom »Brainpower - How Intellectual Capital Is Becoming America's Most Valuable Asset «. To je bil prvi članek o intelektualnem kapitalu v strokovni literaturi in je izzval veliko zanimanje za to področje ter sprožil ekonomska raziskovanja tega novega koncepta in razvoja teorije o intelektualnem kapitalu. Rast vsakega podjetja je vedno bolj odvisna od znanja patentov, procesov, upravljanja znanja, tehnologij, informacij o kupcih in dobaviteljih ter preteklih izkušenj.

Za vsako organizacijo je pomembno, da ima pripravljen izobraževalni načrt. Za izobraževanje zaposlenih sta na voljo redno izobraževanje in izobraževanje ob delu. Pri rednem izobraževanju se zaposleni določeno obdobje izobražuje in praviloma ne opravlja delovnih obveznosti v organizaciji. Za izobraževanje ob delu pa je značilno, da zaposleni opravlja svoje delo in se hkrati tudi izobražuje. Občasno zaposleni, ki se izobražujejo ob delu, v času delovnega procesa zaradi potreb izobraževanja (kolokviji, izpiti, projekti, zaključek izobraževanja z namenom priprave formalne listine, ki predstavlja zaključek izobraževanja) niso na delovnem mestu. V takih primerih so izjemoma opravičeni, da na določen dan niso v službi.

Za številne organizacije pa je tudi značilno, da same organizirajo interno izobraževanje z namenom izobraževanja za točno določeno področje dela (trženje, računovodstvo, davki, upravljanje s posameznimi stroji, uporaba določenih računalniških programov). Zaposleni, ki se udeležijo teh izobraževanj, imajo pogosto tudi večji interes zanje, saj jim bo pridobljeno znanje koristilo pri opravljanju njihovega poklica. Zaradi tega bodo zadovoljnejši z delom in tudi organizacija, ki je za svoje zaposlene organizirala tovrstno izobraževanje, investira $\mathrm{v}$ znanje svojih zaposlenih $\mathrm{z}$ namenom neposredne uporabe pridobljenega znanja v praksi. Gre za interno izobraževanje, ki je način izobraževanja, s katerim podjetje za- 
gotavlja nadaljnje izobraževanje zaposlenih, da bi tako izboljšalo njihove spretnosti.

Ena ključnih oblik izobraževanja in usposabljanja je akcijsko učenje, ki je proces z dvema ciljema, ki se medsebojno dopolnjujeta. Udeleženci se spoprijemajo z resničnimi delovnimi problemi, nalogami ali s projekti v povezavi s specifičnimi metodami in oblikami učenja. Osnovni cilj akcijskega učenja je učiti se in naučiti se, sekundarni cilj pa je učiti se na konkretnem problemu in ga obenem tudi rešiti (Miglič 1998).

Za odrasle je akcijsko učenje $\mathrm{v}$ številnih primerih preizkušena metoda učenja, ki omogoča pospešeno učenje udeležencev izobraževanja in usposabljanja, ker poudarja učenje s praktičnim delom v dejanskem delovnem okolju in skupinsko projektno delo na določeni nalogi (Miglič 1998). Posamezniki se drug od drugega učijo, med njimi poteka izmenjava zamisli in izkušenj. Bistvenega pomena pri akcijskem učenju je postavljanje vprašanj. Zaposleni se v svojem delovnem okolju stalno srečujejo z novimi situacijami in vprašanji, zato se morajo naučiti, kako se spopasti s spremembami. Akcijsko učenje ima pomembno vlogo pri razvoju organizacije in razvoju posameznika. Kot vsaka metoda učenja ima tudi akcijsko učenje določene prednosti in slabosti, ki jih mora vsak udeleženec izobraževanja in usposabljanja poznati. Prednosti so predvsem (Miglič 1998): akcijsko učenje kot glavnega posrednika za učenje uporablja resnični problem neke organizacije, zagotavlja način za učinkovito učenje pri delu tako za posameznika kot za celo skupino, daje posamezniku možnost učinkovitega sodelovanja z drugimi, vplivanja nanje in dopuščanja, da drugi vplivajo nanj, temelji na aktivnem učenju, uporablja raznovrstne izkušnje več posameznikov, ponuja številne pristope, vključno z reševanjem problemov, izvajanjem raziskav, osebnim mentorstvom in vodenjem, opogumlja udeležence, da sami načrtujejo svoje izkušnje, iz katerih se učijo, posamezniku pa omogoča prepoznavanje njegovih lastnih učnih tehnik in načinov.

Za številna podjetja so pomembni procesno usmerjeni seminarji, ki so lahko interne ali eksterne narave, so pa oblika izobraževanja in usposabljanja, kjer se pridobivajo nova spoznanja skozi prizmo preteklih izkušenj, kjer je najpomembnejša povezava učnih vsebin s prakso.

\section{Učeča se organizacija}

Po Garvinu (1993) je učeča se organizacija usposobljena ustvarjanja, akumuliranja in prenašanja znanja ter usposobljena za spremembe vedenja na podlagi novopridobljenega znanja. Učeča se organizacija dosega pred- 
nosti na naslednjih področjih (Garvin 1993): preizkušanje novih postopkov, učenje na podlagi izkušenj, sistematično reševanje problemov, učenje iz primerov drugih in hitro ter učinkovito prenašanje znanja $v$ vse dele organizacije.

Management je temeljna sposobnost, $s$ katero lahko organizacija inovira proizvodne procese $\mathrm{v}$ učeči se organizaciji. Tradicionalni vidik managerjev (Markič 2004, 55), ki določajo smotre in cilje, odločajo in urejajo zadeve ter ukazujejo sodelavcem, odraža sebičnost. Poslovodenje $\mathrm{v}$ učeči se organizaciji zahteva nekaj več. Managerji pomagajo sodelavcem podjetje ali drugo organizacijo razumeti kot organizacijski sistem, podpirajo skupinsko delo, spodbujajo spremembe in razvijajo sposobnosti sodelavcev, da lahko ustvarjajo prihodnost.

Posamezne ravni managementa potrebujejo za svoje delovanje različno strukturo in obseg posameznih znanj, ki ustrezajo zahtevam in potrebam njihovega dela. Najsplošneje lahko predpostavimo, da management pri svojem delu potrebuje celoto konceptualnih, tehničnih, tehnoloških in administrativnih znanj ter znanj o delu z ljudmi (Potočan, Kajzer in Marn 2004, 68).

\section{Vloge in odgovornosti pri razvoju izobraževanja v učeči se organizaciji}

Management se mora zavedati, da je visoka raven delovne učinkovitosti lahko le rezultat čim bolj izrabljenih sposobnosti in kompetenc zaposlenih, ki pa bodo vso svojo ustvarjalnost pokazali, ko bodo sami vpleteni v razvoj delovnega mesta in nalog, torej takrat, ko bodo sooblikovalci lastne kariere oz. izobraževalne poti (Brečko 2005). V organizacijah, v katerih se odgovornost in pristojnosti selijo navzdol, sta klasična vloga managerja in s tem njegova moč seveda ogroženi. To še zdaleč ne pomeni, da $\mathrm{v}$ prihodnosti managerjev ne bo, da bosta poklic in funkcija managerja izginila, kajti še vedno bo moral nekdo usmerjati zaposlene, bdeti nad njihovim poklicnim in osebnostnim razvojem, jim svetovati in jih voditi skozi delovni proces kot mentor. Tako kot se spreminjajo mnogi poklici, se spreminjata vloga in poklic managerja. Za razvoj učeče se organizacije bo treba sprejeti in izvajati za marsikoga popolnoma novo managersko filozofijo. Koncept učeče se organizacije bo torej lahko popolnoma zaživel le takrat, ko bo vsak prevzel odgovornost za učenje in osebni razvoj. To pomeni, da se skrb za razvoj kariere seli na področje posameznika, ki pri ustvarjanju lastne kariere ne sme biti več odvisen zgolj od nadrejenih in organizacije. Ena najopaznejših značilnosti pri razvoju kariere v učeči se organizaciji je prav vključenost posameznikov in celo skupin $\mathrm{v}$ ta proces. 


\section{Timsko delo}

Timsko delo (Riley 20or) zahteva, da si vsi člani prizadevajo v isti smeri in ne da se posameznik obda z oklepom in varuje svoj položaj pred vsakomer. Timsko delo je edina pot, po kateri lahko dosežemo trenutke vrhunskih doživetij, ustvarjamo preboje, ki nam določijo kariero, izpolnimo življenje s trajnim občutkom smisla, saj je vsak tim postavitev prizorišča, je prostor, kjer odigramo igro svojega življenja. Kadar se naš tim odlikuje, zmagamo. Naša najboljša prizadevanja skupaj s prizadevanji soigralcev zrastejo v nekaj, kar je veliko večje od tistega, kar bi dosegli sami.

Timski način dela je nepogrešljiv takrat, ko pot reševanja, rešitev, število rešitev in način reševanja problema niso znani. Tedaj so dobrodošla številna mnenja, ki po usklajevanju lahko dajo najboljšo rešitev. $\mathrm{V}$ takšnih primerih skušamo sestaviti skupino ljudi s podobnim, vendar heterogenim znanjem in s takšnimi osebnostnimi lastnostmi, ki omogočajo hitro nastajanje tima (Lipičnik 1998).

Na začetku tretjega tisočletja gre za razvoj nove, sodobne organiziranosti podjetij, kjer je znanje najpomembnejši vir, ki ga je mogoče obravnavati kot vhod in izhod organizacije. Intelektualni kapital podjetja, v katerem se v osnovi nahaja znanje, predstavlja portfelj nevidnih sredstev podjetja in je pomemben del celotne vrednosti podjetja. Čeprav ni v bilanci stanja, je nesporno, da ima neko vrednost, ki predstavlja čedalje večji delež celotne vrednosti podjetja. Intelektualni kapital vključuje številne elemente, ki so v stalni interakciji in povezani s strukturo trga, družbe in človeka kot najpomembnejšega elementa, ki ima znanje, osnovo za učinkovito uporabo sredstev in ustvarjanje dovolj dodane vrednosti za podjetje in njegove lastnike.

\section{Ekonomska učinkovitost izobraževanja}

Različne analize dejavnikov, ki vplivajo na gospodarski razvoj, so pokazale znaten vpliv izobraženosti ali ravni človeškega dejavnika. Pogoj za uspeh organizacije so ljudje in njihove zmožnosti. Slednje se delijo na (Lipičnik 1994, 4): sposobnosti - gre za zmožnosti, ki odločilno vplivajo na reševanje težav s povsem neznanimi rešitvami; znanja - ta omogočajo reševanje znanih problemov, takšnih, na katere je posameznik že naletel in jih tudi rešil; spretnosti - to so zmožnosti, ki se nanašajo na človekova motorična znanja in sposobnosti, osebne lastnosti, med katere prištevamo temperament.

Koristi od izobraževanja delimo na (Čelebič 200I, I 8):

- zasebne - z zviševanjem izobrazbene ravni se zvišujejo tudi osebni dohodki, 
- družbene - bolj izobražena delovna sila ustvarja večji nacionalni output, omogoča večjo prilagodljivost tehnološkim spremembam in $\mathrm{z}$ večjo zaposlenostjo praviloma znižuje stroške za različne oblike socialne pomoči. 



\section{Organizacijska klima}

Organizacijska klima ima pri poslovanju podjetij čedalje večji pomen, saj dobra organizacijska klima prispeva k uspešnejšemu poslovanju številnih podjetij, tako podjetij, ki se ukvarjajo s proizvodno, kot tudi tistih, ki se ukvarjajo s storitveno dejavnostjo. S. Treven (1998, I27) poudarja, da so $\mathrm{v}$ podjetjih pomembni prijateljski medsebojni odnosi, ki jih vzpostavljamo in vzdržujemo predvsem tako, da skrbimo za sproščeno vzdušje, ki mora biti še vedno profesionalno, spodbujamo zdravo tekmovalnost med zaposlenimi, vse zaposlene obravnavamo enako, spodbujamo odkrit pogovor itd.

\section{Opredelitev, razvoj in vrste organizacijske klime}

T. Mihalič (2007) pravi, da gre pri organizacijski klimi za večjo medsebojno povezanost s postopki, procesi, politiko, internim okoljem, strukturo zaposlenih idr. Kultura organizacije je povezana s preteklostjo in usmerjena v prihodnost. Pretekle izkušnje nam lahko pomagajo pri sprejemanju prihodnjih odločitev, čeprav na prihodnost ne moremo vplivati v celoti. Spreminjanje kulture je izjemno dolgotrajno in težavno. Za upravljanje organizacijske klime je značilno, da je povezano s sedanjim stanjem in je pogojeno zgolj s spremembo trenutnega stanja in aktualnih razmer.

Za razvoj organizacijske klime je $\mathrm{v}$ primerjavi z organizacijsko kulturo značilno, da je hitrejši in je vezan na trenutno časovno obdobje. Dejavniki, ki vplivajo na razvojno dinamiko klime, so (Mihalič 2007, 25): izkazana solidarnost med zaposlenimi, stopnja avtonomije zaposlenih pri delu, načini in oblike poslovanja, doseganje kratkoročnih ciljev, stopnja 
zadovoljstva zaposlenih, struktura zaposlenih v organizaciji, uveljavljenost timskega dela, stopnja pripadnosti zaposlenih, stopnja fluktuacije, zadovoljstvo z rezultati del in nalog, intenzivnost in vrste interakcij med ljudmi, kompleksnost procesov itd.

M. Bernik idr. (2000) poudarjajo, da so pomembne predvsem vrednote delovna učinkovitost, ustvarjalnost in izpolnjevanje dolžnosti, medtem ko sta poslušnost in varčnost kot osebni vrednoti manj pomembni.

$\mathrm{V}$ podjetju je treba ugotoviti najprej obstoječe stanje. $\mathrm{Z}$ analiziranjem organizacijske klime (Meško Štok 2009) ugotovimo le površinsko sliko organizacije in se s tem osredotočimo le na določljiva področja, na katerih so potem potrebne prenove oz. izboljšave. S predlogi rešitev si lahko pomagamo pri akcijskem načrtu dejavnosti, $s$ katerim vplivamo na organizacijsko kulturo in ugotovimo možne vzvode za spremembe, seveda pa je vloga najvišjega vodstva organizacije pri tem ključnega pomena.

Poleg naštetih dejavnikov, ki vplivajo na razvojno dinamiko organizacijske kulture in klime, pa je razvoj obeh odvisen tudi od nekaterih splošnih pogojev. Ti so vezani predvsem na velikost organizacije, njeno strukturiranost, širše poslovno okolje, dejavnost organizacije in podobno (Mihalič 2007, 26). Ne glede na to, da je razvoj organizacijske kulture v splošnem počasnejši in zahtevnejši ter razvoj organizacijske klime hitrejši in enostavnejši, pa sta razvoja tako kulture kot klime vedno hitrejša in enostavnejša v manjših organizacijah kot pa v velikih. Tako bo razvoj kulture in klime najdinamičnejši npr. $v$ majhnem podjetju, nekoliko manj $v$ srednje velikem podjetju in najmanj $v$ velikem podjetju. Vzrok je seveda $v$ tem, da vsaka sprememba v velikih sistemih počasneje vpliva na kulturo in klimo in vsaka sprememba kulture in klime v velikih sistemih kasneje tudi povzroči spremembe na drugih področjih.

Občutek pripadnosti zaposlenih ne prispeva samo k večji učinkovitosti podjetja (boljšim rezultatom, zmanjševanju odsotnosti idr.), ampak tudi $\mathrm{k}$ vtisu, ki si ga o podjetju ustvarijo potrošniki. O občutku pripadnosti in predanosti podjetju lahko govorimo, kadar zaposleni (Musek Lešnik 2007): verjamejo v cilje podjetja in jih sprejmejo kot svoje, so pripravljeni trdo delati za dobrobit podjetja in so trdno odločeni ostati v podjetju. Pripadnost podjetju ima lahko tri osnovne izvore: vdanost (vključevanje $\mathrm{v}$ podjetje zaradi specifičnih nagrad - koristnost), istovetenje (identificiranje - vključevanje $\mathrm{v}$ podjetje na podlagi želje po občutku sprejetosti), ponotranjenje (vključevanje v podjetje zaradi skladnosti med osebnimi in organizacijskimi vrednotami). 


\section{Dimenzija kakovosti in količine dela v organizaciji}

Za podjetja je kakovost $\mathrm{v}$ konkurenčnem boju na trgu čedalje pomembnejša. Ne gre le za konkurenčno prednost, ampak vse bolj za konkurenčno nujnost. $S$ to dimenzijo organizacijske klime poskušamo ugotoviti, ali se zaposleni zavedajo, da so vpliven in odgovoren člen pri doseganju standardov kakovosti. Za dimenzije kakovosti in količine dela $\mathrm{v}$ organizaciji so pomembni (Mihalič 2007): merila za doseganje določene stopnje kakovosti in količine pri delu in nalogah, stopnja ponosa zaposlenih na stopnjo kakovosti izvedenih del in nalog, stopnja odgovornosti zaposlenih za doseganje kakovosti in količine dela oddelka, nagrajevanje nadpovprečne kakovosti in količine opravljenih del in nalog, stopnja prizadevanja zaposlenih za čim kakovostnejše opravljanje del in nalog, razmerje med pomembnostjo kakovosti in količine pri delu, stopnja poznavanja meril za doseganje kakovosti in količine na strani zaposlenih, prisotnost napak pri delu in odstopanj od meril kakovosti in količine, stopnja prevzemanja odgovornosti za doseženo kakovost in količino, prizadevanja za permanentno izboljševanje kakovosti ter prisotnost medsebojnega spodbujanja $\mathrm{k}$ doseganju vedno višje kakovosti.

\section{Dimenzija inovativnosti in samoiniciativnosti $v$ organizaciji}

S to dimenzijo organizacijske klime ocenjujemo ozaveščenost zaposlenih o pomenu inovativnosti. Inovacije in inovativnost niso le stvar vodstva, ampak vseh zaposlenih v podjetju, zato naj bi predloge za izboljšave dajali vsi. Likar idr. $(2000,7)$ pravijo: »Inovativnost je lastnost ljudi. Osnova za inovacijo je invencija. Invencija je vsaka nova zamisel, ki obeta koristi; inovacija iz nje nastane, ko jo kdo razvije do popolne uporabnosti in ko jo poleg tega odjemalci sprejmejo, kupijo in uporabijo ter omogočijo avtorju, izdelovalcu in prodajalcu zaslužek, ker jo štejejo za koristno.«

Med dimenzije inovativnosti in samoiniciativnosti v organizaciji sodijo (Mihalič 2007): stopnja rednega podajanja predlogov, idej in zamisli za izboljšave, delež inovacij in invencij na zaposlenega v organizaciji, stopnja izvajanja načrtnega spodbujanja inovativnosti vseh zaposlenih, intenzivnost razmišljanja zaposlenih o novih načinih boljšega opravljanja del in nalog, nagrajevanje dobrih predlogov, idej in zamisli, stopnja načrtnega razvijanja in spodbujanja samoiniciativnosti zaposlenih, prisotnost in kakovost sistema načrtnega zbiranja, izbiranja (selekcioniranja) in uvajanja idej, stopnja pripravljenosti zaposlenih za prevzemanje tveganj pri aplikaciji lastnih idej, pogojevanje nagrad in napredovanj z inovativnostjo in s samoiniciativnostjo. 


\section{Dimenzija vodenja in participacije $\mathbf{v}$ organizaciji}

Dimenziji notranji odnosi in vodenje se dopolnjujeta in prekrivata, saj odnose v družbi ustvarjajo predvsem vodilne osebnosti. Zato je razumljivo, da slog vodenja pomembno vpliva na oblikovanje organizacijske klime. Predpostavljeni lahko uveljavi svoje zahteve na avtoritativen, ukazovalen način, ob katerem se podrejeni pogosto počutijo nepomembne, kar lahko vodi v slepo izpolnjevanje ukazov nadrejenega ali pa se med njimi ustvari konflikt. Organizacijska klima je boljša v družbah, kjer prevladuje demokratični slog vodenja, ki daje posamezniku možnost, da izraža svoje ideje in zamisli (Mihalič 2007). Vodja zaposlenim daje občutek pomembnosti in zaupanja, zna ustvariti sproščene odnose, hkrati pa je tudi neizprosno zahteven glede izpolnitve konkretnih nalog. Podrejeni tedaj ve, da mora svoje naloge opraviti dobro, hkrati pa se počuti upoštevanega, zato naredi vse, da bo svoje delo opravil kar najbolje.

$\mathrm{Na}$ klimo v družbi pomembno vpliva tudi usklajenost vodenja. Vodstvo družbe je v rokah določenega števila ljudi. Če je usklajeno, vsak ve, kaj, kdaj in kako mora kaj storiti. Zaposleni v podjetju s svojim delom prispevajo $\mathrm{k}$ doseganju podjetniških ciljev, vendar imajo tudi svoje interese in cilje, ki jih želijo uresničevati s svojim delovanjem. Nenazadnje so vsi interesi posameznikov vgrajeni v družbene zahteve do podjetij (delodajalcev) in zaposlenih (delojemalcev), kjer so interesi delodajalcev pokrivanje stroškov, učinkovitost poslovanja, dobiček itd., glavni interesi delojemalcev pa zagotovljeno delovno mesto, pošteno in pravično plačilo, zaščita zaposlenih, dobro delovno okolje itd. Med dimenzije vodenja in participacije v organizaciji T. Mihalič (2007) vključuje: stopnjo uporabe vodenja s cilji in vodenja $z$ razgledovanjem ter poslušanjem, intenzivnost od neposredno nadrejenih prejete podpore in zaščite zaposlenih pri delu, razmerje med hvaljenjem in spodbujanjem ter kritiziranjem in zastraševanjem, stopnjo sodelovanja zaposlenih pri odločitvah, vezanih na lastno delo, stopnjo medsebojnega spoštovanja in cenjenja strokovnosti med zaposlenimi in vodji, stopnjo povratnega informiranja o uspešnosti zaposlenih pri delu, stopnjo priznavanja avtoritete vodij na strani zaposlenih, stopnjo občutenja zaposlenih kot enakopravnih sogovornikov v odnosu do vodij, vlogo in mesto človeškega kapitala, človeških virov in zaposlenih $\mathrm{v}$ organizaciji, stopnjo pomoči vodje zaposlenim in hkratno spodbujanje njihove samostojnosti, stopnjo normativne ureditve vodenja zaposlenih $\mathrm{z}$ navodili, kodeksi etike ipd.

\section{Dimenzija nagrajevanja in motiviranja v organizaciji}

N. Zupan (1998) poudarja, da mora biti sistem nagrajevanja prvotno podrejen zakonodaji v posamezni državi, po drugi strani pa mora izhajati iz 
strategije same družbe. Vključuje finančne nagrade in ugodnosti pri delu pa tudi nefinančne nagrade, kot so priznanja, pohvale za dosežke, osebni razvoj itd., ter sistem nagrajevanja uspešnosti. Posebno pozornost je treba nameniti učinkom, ki jih ima sistem nagrajevanja na vedenje posameznikov kot tudi za družbe, zato s to dimenzijo merimo, kako podjetje izpolnjuje pričakovanja zaposlenih glede nagrad za dobre rezultate, plač, ki naj bi bile vsaj enakovredne ravni plač na tržišču. Merila za materialno nagrajevanje morajo biti jasna, znana in merljiva.

$S$ to dimenzijo organizacijske klime ugotavljamo zavzetost zaposlenih za njihovo delo, zadovoljstvo $\mathrm{z}$ informiranostjo $\mathrm{v}$ družbi in pripravljenost zaposlenih za dodaten napor, kadar je to pri delu potrebno. Zanima nas tudi, ali v družbi cenijo dobro opravljeno delo, ali so dobri delovni rezultati pohvaljeni in kako zaposleni dojemajo zahteve glede delovne uspešnosti.

Zaposlene moramo nagraditi za naslednja dejanja, uspehe in prizadevanja sodelavcev (Mihalič 2007): uspešnost in učinkovitost pri delu, predlaganje zamisli, idej in razvoj novosti, pridobitev novih znanj in drugih kompetenc, inoviranje in uvajanje izboljšav pri delu, aktivno uporabo in širjenje znanj na sodelavce, prizadevnost in visoko storilnost pri delu, izraženo solidarnost in pomoč sodelavcem, ustvarjeno dodano vrednost, uspešno sodelovanje $\mathrm{v}$ timu, skupini in $\mathrm{z}$ vodstvom, požrtvovalnost za tim, skupino in organizacijo, razvoj lastnih zmožnosti in sposobnosti, pridobitev novih kupcev, strank in partnerjev, izkazan prispevek k dobremu imenu organizacije, druge uspehe, dosežke ter pozitivna dejanja. Nedenarne nagrade so eden izmed najboljših načinov motiviranja zaposlenih.

\section{Napredovanje in premeščanje}

$\mathrm{V}$ številnih podjetjih poteka sistematičen in načrtovan razvoj zaposlenih in napredovanje na delovnem mestu je normalen pojav. Pri pokrivanju potreb na novih delovnih mestih $\mathrm{z}$ obstoječimi zaposlenimi v podjetju prinaša kar nekaj prednosti to, da kandidate že poznamo. Izbira je hitrejša in cenejša, v številnih primerih pa so zaposleni zaradi napredovanja tudi bolj motivirani. Seveda pa lahko pri notranjem napredovanju pride do nepričakovanih odnosov ostalih sodelavcev, če eden izmed njih napreduje in tudi če pri napredovanju sodelavca težko najdemo nadomestilo zanj. V številnih primerih pa prihaja tudi do premeščanj zaposlenih, zlasti v velikih podjetjih, ki imajo več svojih organizacijskih enot, kjer sta potrebna sklep kadrovske službe in soglasje pristojnega nadrejenega, seveda pa so lahko tudi notranji razpisi priložnost za kandidiranje zaposlenih $\mathrm{v}$ podjetju na boljša delovna mesta. 
Med dimenzije nagrajevanja in motiviranja v organizaciji T. Mihalič (2007) uvršča: stopnjo opredeljenosti in preglednosti meril za nagrajevanje, intenzivnost nagrad in pohval zaposlenim za dobro opravljeno delo, stopnjo poznavanja pogojev za prejem nagrade, prisotnost sistema nagrajevanja kompetenc zaposlenih, intenzivnost sankcij in graj zaposlenim za slabo opravljeno delo, stopnjo spodbujanja in navduševanja zaposlenih, prizadevanje zaposlenih za doseganje odličnosti in spodbujanje te odličnosti, razmerje med nagradami in pohvalami ter sankcijami in grajami, prisotnost tako denarnega kot nedenarnega nagrajevanja, stopnjo strahu zaposlenih pred sankcijami, prisotnost medsebojnega spodbujanja in navdušenja med sodelavci, ustreznost politike nagrajevanja in celotnega sistema izvajanja motiviranja ter nagrajevanja.

\section{Dimenzija kakovosti medsebojnih odnosov v organizaciji}

Delo, ki ga opravljajo zaposleni v proizvodnih in storitvenih dejavnostih, zahteva kakovostne medsebojne odnose, saj se moramo zavedati, da so pri tako številnih in različnih delovnih nalogah znotraj posameznega podjetja medsebojni kakovostni odnosi tisti, ki močno prispevajo h kakovosti in količini opravljenega dela. Med zaposlenimi so potrebni zaupanje, spoštovanje, odkritost, skupni napori idr., da bi medsebojni odnosi lahko bili na primerni ravni, kar bo omogočalo nemoteno poslovanje nekega podjetja.

$S$ kakovostjo medsebojnih odnosov ne preučujemo samo medsebojnih odnosov med zaposlenimi, ki opravljajo enako ali podobno delo, ampak tudi odnos med lastniki, managerji, vodji in tudi drugimi zaposlenimi. Pri tem je vsekakor pomembno, da managerji, lastniki, vodje dobro opravljeno delo podrejenih cenijo in spoštujejo ter da skupaj skrbijo za dobre medsebojne odnose v organizaciji. Zadovoljni zaposleni so tudi tisti, ki vplivajo na ugled podjetja in predstavljajo vir informacij za številne medije, hkrati pa so tudi imidž (slika, podoba) podjetja. Za dimenzije kakovosti medsebojnih odnosov v organizaciji so pomembni (Mihalič 2007): razmerje med sodelovanjem in tekmovanjem med zaposlenimi, stopnja medsebojnega zaupanja v organizaciji, kakovost medsebojnih odnosov med zaposlenimi ter posebej med vodji in sodelavci, stopnja spoštovanja in cenjenja dela naporov ter dosežkov med zaposlenimi, intenzivnost sprotnega konstruktivnega reševanja konfliktov med zaposlenimi, stopnja profesionalnosti in etičnosti $\mathrm{v}$ medsebojnih odnosih, pogostost sporov in destruktivnih nesoglasij med zaposlenimi, prisotnost prijateljskih odnosov med zaposlenimi, razmerje med formalnim in neformalnim druženjem med zaposlenimi, strukturiranost neformalnih sku- 
pin znotraj organizacije, intenzivnost medsebojne pomoči in podpore, stopnja homogenosti skupin in timov v primerih kriznih situacij.

\section{Dimenzija organiziranja in odgovornosti v organizaciji}

Lastniki družbe dajejo skupno nalogo družbe v izvedbo managerjem, ti pa svoje naloge, dolžnosti ali zadolžitve naložijo podrejenim. Tako se tvorijo razmerja oz. hierarhija v družbi. Management prenese na podrejene zadolžitve in odgovornosti, hkrati pa tudi moč oz. oblast za izvedbo naloge. Rozman, Kovač in Koletnik (1993) avtoriteto opredelijo kot »moč, povezano z delovno nalogo, izvirajočo iz položaja v podjetju«.

$\mathrm{V}$ okviru projekta SiOK so raziskovalci poskušali ugotoviti, ali v družbah zaposleni prevzemajo odgovornost za rezultate svojega dela, imajo jasno predstavo o tem, kaj se od njih pričakuje, razumejo svoje mesto $\mathrm{v}$ organizacijski shemi, ali vodje sprejemajo odločitve pravočasno in spodbujajo samostojnost zaposlenih pri delu.

Za dimenzije organiziranja in odgovornosti $\mathrm{v}$ organizaciji so pomembni (Mihalič 2007): stopnja poznavanja individualnih pristojnosti in odgovornosti na strani zaposlenih, ustreznost procesov in postopkov za optimalno opravljanje del in nalog, možnosti povečanja uspešnosti in učinkovitosti zaradi boljše organiziranosti, razmerje med obremenitvami zaposlenih z deli in nalogami, stopnja natančnosti predstave zaposlenih o pričakovanjih do njih, stopnja razumevanja položaja in vloge zaposlenih $\mathrm{v}$ oddelku in celotni organizaciji, stopnja strukturiranosti celotne organizacije, integracija posameznih organizacijskih enot za doseganje skupnih ciljev, stopnja avtonomnosti zaposlenih pri opravljanju del in nalog, položaj in vloga kupcev v organiziranosti poslovnega sistema, stopnja hierarhičnosti organizacije, stopnja tveganja za posameznika, oddelke in organizacijo.

\section{Dimenzija izobraževanja, izpopolnjevanja in usposabljanja v organizaciji}

Znanje je ključni dejavnik konkurenčnosti, zato mu uspešna podjetja namenijo veliko pozornosti in sredstev. Podjetja uporabljajo različne programe usposabljanja zaposlenih, poleg tega pa morajo zagotoviti prenos znanja med zaposlenimi. Tako so $\mathrm{v}$ to dimenzijo klime vključene trditve, da se zaposleni, ne glede na starost, delovno dobo in položaj, učijo od drugih, da so zaposleni le ljudje, ki so usposobljeni za svoje delo, da podjetje nudi potrebno usposabljanje za dobro opravljeno delo in upošteva tudi želje zaposlenih. Zanima nas mnenje zaposlenih o sistemu usposabljanja $\mathrm{v}$ njihovem podjetju. $\mathrm{V}$ podjetju se morajo zavedati, da so le iz- 
obraženi, usposobljeni delavci, ki so voljni razvijati svoje sposobnosti in hkrati prispevati $\mathrm{k}$ rasti podjetja, pomemben element, ki povečuje zadovoljstvo, gradi osebnostni razvoj ter posredno povečuje vrednost podjetja (Černetič 2007, 302). Za dimenzije izobraževanja, izpopolnjevanja in usposabljanja v organizaciji so pomembni (Mihalič 2007): enakopravnost glede možnosti za pridobivanje novih in širjenje obstoječih znanj, kakovost in količina pridobivanja novih znanj in veščin, potrebnih za uspešno delo, stopnja permanentnega učenja vseh zaposlenih, izpostavljanje znanja kot vrednote zaposlenih, kakovost celostnega sistema izobraževanja, izpopolnjevanja in usposabljanja, prisotnost mehanizmov sistematičnega pritekanja znanj kot dolžnosti in pravice vseh zaposlenih, stopnja razvijanja načel učeče se organizacije in organizacije znanja, stopnja sistema načrtnega razvoja kompetenc zaposlenih, stopnja medsebojnega prenosa znanj in veščin med zaposlenimi, stopnja zavedanja o pomenu stalnega nadgrajevanja znanj za lastno konkurenčnost.

\section{Dimenzija razumevanja in udejanjanja razvojne strategije v organizaciji}

Pomen dimenzije razumevanja in udejanjanja razvojne strategije $\mathrm{v}$ organizaciji vključuje (Mihalič 2007): stopnjo razumevanja razvojne strategije na ravni oddelkov in celotne organizacije, stopnjo poznavanja politike in ciljev na strani zaposlenih, stopnjo sprejemanja ciljev oddelka in organizacije za svoje individualne cilje, stopnjo sodelovanja in prispevanja zaposlenih pri oblikovanju ciljev oddelka, stopnjo realnosti opredeljenih kratkoročnih in dolgoročnih ciljev, stopnjo udejanjanja politike v praksi, stopnjo preglednosti vizije, strategije, politike in ciljev, stopnjo doseganja razvojnih načrtov organizacije.

\section{Dimenzija načina internega komuniciranja v organizaciji}

Interno komuniciranje je zelo pomembno tudi za manjša podjetja, kjer se zaposleni med seboj relativno dobro poznajo; pomen internega komuniciranja se kaže tudi takrat, ko zaposleni zaradi poslovnih razlogov zapušča delovno okolje in se seveda ostali zaposleni sprašujejo, ali in kdaj bodo tudi oni na vrsti. Za majhna podjetja je značilno, da ima pri internem komuniciranju običajno najpomembnejšo vlogo vodstvo podjetja, seveda pa se morajo zaposleni počutiti varno, sprejeto in cenjeno, da bodo lahko kar najbolje uresničevali cilje podjetja in opravljali svoje delo točno, vestno in natančno. Interno komuniciranje je pomembno tudi za turistične agencije v Sloveniji (Bojnec in Kribel 2006), ki kot informacijsko-komunikacijsko in tržno orodje uporabljajo internet. Interno komuniciranje lahko 
poteka tudi v obliki internih časopisov, oglasnih desk, notranjih anket o zadovoljstvu, elektronske pošte, videokonferenc idr.

Za dimenzije načina internega komuniciranja $v$ organizaciji so pomembni (Mihalič 2007): stopnja razvitosti demokratičnih in nehierarhičnih načinov komuniciranja, stopnja izvajanja aktivne dvosmerne komunikacije, spodbujanje konstruktivnega in odprtega dialoga, stopnja stalnega (permanentnega) komuniciranja med vodjo in sodelavci, stopnja prisotnosti prijateljske in sproščene komunikacije med zaposlenimi, intenzivnost reševanja konfliktov z dialogom, možnosti odkritega pogovora med zaposlenimi in vodjo, brez bojazni pred sankcijami, prisotnost prikritega komuniciranja med zaposlenimi, kakovost izvajanja rednih dnevnih, tedenskih in mesečnih sestankov, stopnja sprotnega reševanja nastalih problemov $\mathrm{v}$ komunikaciji, prisotnost motenj in napak $\mathrm{v}$ internem komuniciranju.

\section{Dimenzija informiranosti v organizaciji}

Za dimenzije informiranosti v organizaciji so pomembni (Mihalič 2007): razmerje med deležem formalno in neformalno prejetih informacij, stopnja pravočasnega posredovanja potrebnih informacij sodelavcem, stopnja povratnega informiranja o dosežkih in (ne)zadovoljstvu z delom posameznika, stopnja razumevanja prejetih informacij, ki jih posreduje vodstvo, razmerje med informiranostjo o delu oddelka in o delu na ravni celotne organizacije, prisotnost preverjanja in razumevanja informacij, kakovost informacij glede na strokovnost, korektnost in pravočasnost prenosa, pogostost napak pri prenosu informacij, prisotnost občutka o pomanjkanju potrebnih informacij na strani zaposlenih.

\section{Dimenzija razvoja in upravljanja kariere $v$ organizaciji}

Delovne zahteve in sposobnosti zaposlenih se s časom spreminjajo, zato je smiselno načrtovanje kariere. Po mnenju Rozmana, Kovača in Koletnika (1993) razvoj kariere zagotavlja, da so potrebna znanja na voljo, pomaga pridobiti in zadržati sposobne ljudi, zagotavlja sposobnim zaposlenim rast in razvoj ter znižuje fluktuacijo. Pri načrtovanju kariere je treba uskladiti cilje podjetja in posameznika ter upoštevati pričakovanja obeh strani. Sistematičen razvoj karier omogoča določanje ključnih kompetenc posameznikov, ki podjetju omogočajo doseganje večje konkurenčne prednosti, zaposlenim pa odkrivanje že izraženih sposobnosti in tistih, ki jih za doseganje ciljev še potrebujejo (Černetič 2007, 304). 
Ta dimenzija omogoča ugotavljanje zadovoljstva zaposlenih z osebnim razvojem, z možnostjo napredovanja oz. sistemom napredovanja, $\mathrm{ki}$ naj bi omogočal, da najboljši zasedejo najboljša mesta. Zanima nas tudi, ali so merila za napredovanje jasna vsem zaposlenim, ali so zaposleni spodbujeni $\mathrm{k}$ samoiniciativnosti in samostojnosti in/ali vodilni vzgajajo svoje naslednike (Černetič 2007, 304).

Za dimenzije razvoja in upravljanja kariere v organizaciji so pomembni (Mihalič 2007): stopnja definiranosti in preglednosti meril za napredovanje, možnosti in kakovost tako strokovnega kot osebnega razvoja zaposlenih, stopnja razumevanja in poznavanja meril za napredovanje, izvajanje napredovanj na osnovi kompetenc in doseženih rezultatov, intenzivnost sistematičnega kariernega razvoja zaposlenih, opredeljenost pogojev za zasedbo delovnih mest $\mathrm{v}$ okviru kariernega razvoja zaposlenih, izvajanje vertikalnega in horizontalnega napredovanja, intenzivnost sistematičnega razvoja kandidatov za naslednike, uporaba kariernih načrtov zaposlenih, prisotnost enakih možnosti napredovanja za vse zaposlene, pogojevanje napredovanja tudi s stopnjo izražene inovativnosti, dolgoročna usmerjenost kariernega razvoja posameznika, uporaba letnih kariernih razgovorov, stopnja poznavanja možnosti za napredovanje na strani zaposlenih.

Vorina $(2012,49)$ poudarja, da ugotavljanje kompetentnosti zaposlenih pomeni presojo uporabe njihovih zmožnosti v najširšem pomenu besede, in sicer v kontekstu, v katerem je delo opravljeno. Znanja, izkušnje, osebnostne lastnosti ipd. torej razume kot kompetence zaposlenih, ki se oblikujejo $\mathrm{z}$ delom in prakso $\mathrm{v}$ določeni organizaciji, iz česar izhaja, da je treba kompetentnost zaposlenih vedno ocenjevati v okviru organizacije oz. delovne situacije, $\mathrm{v}$ kateri se znajde posameznik.

\section{Merjenje in spreminjanje organizacijske klime}

$\mathrm{Z}$ merjenjem organizacijske klime lahko ugotavljamo, kakšno je zadovoljstvo zaposlenih v podjetju na posameznih delovnih mestih. Organizacijsko klimo lahko spremljamo le nekajkrat v določenem obdobju, lahko pa njeno merjenje postaja praksa, saj lahko pričakujemo, da bomo $s$ povečanjem zadovoljstva zaposlenih vplivali na uspešnost poslovanja podjetja.

Klimo je treba, če ni ugodna, spreminjati. (Ne)ugodnost klime presojamo glede na cilje, ki jih želimo doseči. Če se ljudje ne obnašajo v skladu s pričakovanji in potrebami podjetja, lahko del krivde pripišemo neustrezni klimi. V tem primeru je treba klimo spremeniti. Spremembe organizacijske klime so pogojene tudi z življenjskim ciklom podjetja. $\mathrm{Na}$ 
začetku delovanja podjetja se začne oblikovati določena klima, $\mathrm{z}$ nadaljnjim razvojem in rastjo podjetja pa se pojavi potreba po spreminjanju klime v podjetju. Ko se podjetje znajde v težavah, je sprememba klime nujna. Spreminjanje klime narekuje tudi okolje, $v$ katerem podjetje deluje in hoče preživeti (Černetič 2007, 306).

Predpogoj za spreminjanje neustrezne klime je njeno preučevanje. $S$ tem mislimo na ugotavljanje že navedenih dimenzij klime, vzrokov in posledic klime na vedenje ljudi. Pomembni sta predvsem dve vprašanji (Lipičnik 1998, 79): kako lahko spremenimo klimo in kdo jo lahko spremeni.

\section{Opredelitev motivacije in pomen motivacije za dobro organizacijsko} klimo

Motivirati pomeni spodbuditi ljudi z določenimi sredstvi, motivacijskimi

dejavniki, da bodo dane naloge opravili učinkovito in na podlagi lastne odločitve. Sredstva so lahko različne nagrade, priznanja in druge oblike spodbujanja, ki delujejo v smeri pozitivnega motiviranja in zadovoljujejo osebne potrebe. Grožnje ali kazni so oblike negativnega spodbujanja, ki osebo odvračajo od ciljev in dejanj (Plut in Plut 1995, 67).

Motivacijski dejavniki so primarni (biološki in socialni), sekundarni (interesi, stališča, navade), podedovani in pridobljeni, univerzalni, regionalni in individualni. Motivacijski dejavniki, ki so povezani z delom in vrednotenjem dela, so (Lipičnik 1998, 3 I): primerno delovno okolje, možnost napredovanja, razporeditev delovnega časa, možnosti strokovnega usposabljanja, zanimivo delo, medsebojni odnosi med sodelavci, možnost polnega uveljavljanja delovnih sposobnosti, stalnost in zanesljivost zaposlitve, osebni dohodek, priznanje za uspešnost pri delu in soodločanje o delu in gospodarjenju.

$\mathrm{Na}$ motivacijo najbolj vplivajo trije dejavniki (Lipičnik 1998, 32): individualne razlike, značilnosti dela in organizacijska praksa.

Med materialnimi motivacijskimi dejavniki prevladuje denar - plača (Uhan 2000, 32). Dolgo je veljalo mnenje, da je to edini motivacijski dejavnik, vendar je praksa pokazala, da ni tako.

$\mathrm{K}$ povečanju delovnega učinka in kakovosti dela lahko pripomore tudi kakovost delovnega življenja. $\mathrm{Z}$ boljšo motivacijo, večjim zadovoljstvom delavcev, boljšim komuniciranjem ter zmanjšanjem odpora do sprememb bodo ljudje ustvarjalnejši (Uhan 2000). Kakovost delovnega življenja pa je mogoče povečati tako, da zaposlenim omogočimo, da ob manjših naporih in tveganjih za svoje zdravje več zaslužijo, da pri delu razvijajo in uporabljajo svojo ustvarjalnost in da se v delovnem okolju 
medsebojno podpirajo. Tako je mogoče iz njih pridobiti več ustvarjalnih moči. Zato pa moramo z izbrano organizacijsko obliko doseči sinergijske učinke za hkratno zadovoljevanje potreb delavcev in doseganje poslovnih ciljev.

Motivacija je za socialno vedenje ena najpomembnejših psihičnih funkcij in vsakemu človeku daje značilen pečat posebnosti ali celo enakosti. Pri nobenem človeku se povsem enaki motivi ne ponovijo. Motivacija je proces, ki sproži človekovo dejavnost, jo usmerja v določene objekte, uravnava obnašanje in ga poenoti, poveže $\mathrm{v}$ celoto $\mathrm{v}$ prizadevanju za doseganje ciljev, ki si jih je nekdo zadal (Krajnc 1982, 2r). Storilnost je močno odvisna od vsakokratne motivacije, ta pa je vezana na čustva. Motivacija namreč temelji na potrebah, ki jih organizem doživlja na čustveni podlagi; pojavlja se v obliki potreb, nagibov, nagnjenj, želja, teženj, interesov, hotenj, kar običajno s skupnim izrazom imenujemo motivi ali nagibi. Prav zaradi slednjih se posamezne dejavnosti ljudi povezujejo v smotrno celoto, so medsebojno povezane in smiselne.

Motivacija za izobraževanje je eden vidnejših dejavnikov, ki uravnavajo človekovo učinkovitost pri pridobivanju novega znanja, pri razvijanju spretnosti in navad, novih stališč, pogledov in osebnostnih lastnosti. Poleg motivacije na potek in uspešnost vzgojno-izobraževalnega dela delujejo še sposobnosti in spretnosti za učenje, učne tehnike in navade, splošno psihofizično stanje osebe idr. Razni motivi, med katerimi najdemo zunanje ali socialne in notranje ali subjektivne, vplivajo zlasti na nekaj pojavov učenja: vplivajo na mobilizacijo sposobnosti oseb, ki se izobražujejo, pospešujejo dolgotrajnejše ohranjanje znanja, pospešujejo povezovanje znanja v celoto z že prej pridobljenih znanjem, tako da pri človeku povečujejo asociativno moč, podpirajo večjo fleksibilnost sprejetega znanja, zaradi česar ga je mogoče uporabljati v praksi in ga je moč prenesti v nove življenjske situacije (Krajnc 1982, I 13).

Za spodbuditev motivacije (Weisinger 200I) je včasih dovolj samo en dejavnik, spet drugič jih potrebujemo več. Naučiti se moramo, kako svoje telo vznemiriti in pridobiti energijo za polet. Motivacija je torej povečano telesno vznemirjenje in zavzetost, $s$ katero vsakdanje dejavnosti opravljamo na lažji in predvsem učinkovitejši način. Najlažje svoje telo vznemirimo takrat, ko imamo določena pričakovanja. Zagotovo sem sodijo razgibano delo, višja plača, ustvarjalnost ali morda drugačen delovni čas, zato je prav, da preverimo, koliko so naša pričakovanja realna in kako jih lahko uresničimo.

Hotenje je popolna zavezanost posameznika k doseganju nekega cilja (Bruch 2006). Hotenje se od motivacije razlikuje po tem, da je povezano 
z dejavnostmi za doseganje zastavljenega cilja, medtem ko motivacija posameznika zgolj premakne $\mathrm{v}$ stanje, ki ga želimo in ki je lahko v skrajnem primeru tudi popolnoma statično. Motivacija nastane $\mathrm{v}$ trenutku, ko se posameznik zavestno ali nezavedno odloči za nek cilj, hotenje pa nastopi takrat, ko posameznik začne izvajati dejavnosti za doseganje zastavljenega cilja. Hotenje je torej ključni element vztrajanja pri doseganju zastavljenega cilja, njegova prisotnost (ali odsotnost) vpliva na to, ali bo posameznik določen cilj dosegel ali ne. Motivacija se od hotenja razlikuje tudi po tem, da motivirani posamezniki lahko vedo, kaj bi morali narediti za doseganje cilja, pa se bodo tem nalogam kljub temu izognili, če bodo le presodili, da ovire, ki jih pri tem lahko pričakujejo, presegajo nagrado ob doseženem cilju.

Po Florjančiču in Jesenku (1997, 154) ima človek kot dejavnik kakovosti v turizmu pomembno vlogo, saj človek za delo material izbira - se odloči zanj, ga definira, nabavi, sprejme $v$ proces in z njim dela tudi v procesu dela. Poleg tega človek preko svojih dejavnosti tudi neposredno vpliva na kakovost $\mathrm{v}$ najširšem smislu, saj je ta rezultat njegovega dela, znanja, sposobnosti in vzgoje oz. motivacije za kakovost. 



\section{Turizem}

Turizem je ena izmed najhitreje razvijajočih se panog v zadnjem desetletju. Za razvoj turizma v Sloveniji je med drugim pomembna dobra strategija razvoja turizma $\mathrm{z}$ opredelitvijo ključnih dejavnosti ter opredelitev funkcij deležnikov, ki so soodvisni pri njegovem razvijanju. Pomembno vlogo pri razvoju turizma v Sloveniji, predvsem z vidika emitivnega in receptivnega turizma, imajo tudi turistične agencije, zato jim smemo pripisati velik pomen. $V$ turističnih agencijah zaposleni s svojim človeškim kapitalom in $\mathrm{z}$ organizacijsko klimo prispevajo $\mathrm{k}$ uspešnosti poslovanja turističnih agencij, kar preučujemo tudi v nadaljevanju.

Turizem vpliva tudi na nacionalno gospodarstvo, zato so za turizem pomembne naslednje ekonomske funkcije (Planina in Mihalič 2002): devizna, kompenzacijska, konverzijska, inflacijsko-deflacijska, multiplikacijska in indukcijska.

\section{Razvoj turizma v Sloveniji}

Razvoj turizma v Sloveniji ustvarja priložnosti, ki ugodno vplivajo na celoten gospodarski, socialni in prostorski razvoj države, ter hkrati predstavlja pomembno poslovno priložnost za Slovenijo. Razvoj slovenskega turizma je $\mathrm{v}$ zadnjem obdobju temeljil predvsem na izgradnji infrastrukture, zanemarjeno pa je bilo področje t. i. mehkih razvojnih elementov kakovosti v najširšem pomenu besede, pospešenega izobraževanja za turizem in razvoja človeških virov, spodbujanja inovativnosti in kreativnosti za razvoj in oblikovanje tržno zanimivih, inovativnih ter kakovostnih integralnih turističnih proizvodov (ITP). Turizem se integrira na lokal- 
ni, regionalni in državni ravni, zato je pri strateškem načrtovanju treba upoštevati tudi strateške usmeritve lokalne in regionalne ravni. Turizem vključuje vrsto raznovrstnih dejavnosti, ki imajo za svoj razvoj idealne razvojne strategije (Uran in Ovsenik 2006, I8).

\section{Izraz turizem in opredelitev turizma}

V slovenščini se od druge polovice prejšnjega stoletja splošno uporablja izraz turizem, pred letom 194I pa je bil v rabi izraz tujski promet. Slednja besedna zveza je bila neposredno prevedena iz nemškega jezika, iz izraza $\gg$ fremdenverkehr $\ll$, medtem ko je bila beseda turizem ves čas uporabljana $\mathrm{v}$ francoskem in angleškem jeziku in je bila v svetu v splošni rabi, razen $\mathrm{v}$ nemškem in nekaterih slovanskih jezikih (Mihalič in Planina 2002, 17).

Izraz turizem izvira iz starofrancoskega korena $\gg$ tour «, kar pomeni krožno gibanje, torej gibanje $s$ povratkom $v$ izhodišče. Potem so izraz prevzeli vsi svetovni jeziki. Izraz turist je bil prvič uporabljen v Angliji leta $\mathrm{I} 800$, in sicer ga je uporabil Pegge v svojih $\gg$ Anecdotes of English Language «, kjer je bil napisan danes znameniti stavek: »A Traveller is now-a-days called a Tourist «. Izraz turizem je bil prvič uporabljen leta I8 I I v angleškem časniku Sporting Magazine v članku »Sublime Cockey Tourism《 (Planina 1996, I8).

Turist je oseba, ki briše meje družbenih sistemov in soustvarja nastajajoče globalno družbeno okolje, je družbeno bitje in v idealnem smislu v bistvu družbeni konstrukt (Ambrož 2005, 216).

Turizem se $\mathrm{v}$ življenju uporablja $\mathrm{v}$ različnih oblikah, zato je treba poznati osnovne vrste turizma, torej pridevnike, ki se dodajajo besedi turizem, da bi označili različne pojavne oblike tega pojava in dejavnosti.

Pojem »turist « je za statistične namene opredeljen kot obiskovalec, čigar obisk določenega kraja traja najmanj eno noč, njegov namen pa so bodisi počitnice ali dopust bodisi gre za poslovni oz. službeni obisk bodisi ga vodijo drugi turistični nameni (Medlick 1997, 162).

\section{Turistična destinacija in načrtovanje turističnih destinacij}

Skupno polje različnih opredelitev turističnih destinacij številnih avtorjev identificira naslednje lastnosti (Cooper 20I2):

- Turistične destinacije so nepremične, kar pomeni, da lahko pride do turistične potrošnje le v destinaciji sami. Če želi turist doživeti privlačnosti destinacije, mora biti v njej tudi fizično prisoten. Turistično povpraševanje je po svoji naravi usmerjeno v edinstvene in občutljive dele sveta, zato so take destinacije večkrat pod pri- 
tiskom prevelikega turističnega obiska in to jim povzroča škodo. Dodatna težava je še v sezonskem značaju turističnega povpraševanja ali pa v nenadnem povečanju turističnega povpraševanja po neki destinaciji, ki je trenutno priljubljena in popularna. Sezonski značaj povpraševanja je morda največji problem destinacije. Večina sestavnih elementov destinacije namreč posluje z visokimi fiksnimi stroški, tako da je treba $\mathrm{v}$ običajno kratki visoki sezoni (3-4 mesece) ustvariti dovolj prihodkov, da se z njimi lahko pokrivajo fiksni stroški skozi celo koledarsko leto. $V$ prednosti so destinacije z dolgo sezono.

- V turistični destinaciji običajno živi tudi lokalno prebivalstvo, ki lahko koristi iste storitve kot turisti; lokalno prebivalstvo potrebuje te storitve celo leto, turisti pa so le občasni potrošniki. Poslovne subjekte je možno deliti glede na to, ali svoje storitve nudijo le turistom, le rezidentom ali morda obojim. Turizem lahko postane tudi vir konfliktov in nestrpnosti med lokalnim prebivalstvom in obiskovalci.

- Različni elementi, ki sestavljajo turistično destinacijo, morajo biti komplementarni. Predvsem je pomembno, da je raven kakovosti posameznih elementov turistične ponudbe enotna. Nekakovostna restavracija ali hotelska soba lahko razočara sicer zadovoljnega turista. To komplementarnost je težko doseči in nadzorovati, saj ponudniki turističnih storitev običajno delujejo preveč razdrobljeno.

Zaradi turističnih privlačnosti turisti kupujejo turistične proizvode, ki so prostorsko vezani na destinacijo. Privlačnosti so lahko (Mihalič 1997,34$)$ :

- naravne, kamor sodijo npr. lepa pokrajina, plaže, ugodno podnebje in druge geografske značilnosti;

- zgrajene, ki jih pogosto štejemo k naravnemu (zgrajenemu) okolju, ker navadno posegajo v sam videz pokrajine; $v$ to skupino štejemo npr. turistične in druge zgradbe, spomenike, sprehajališča, parke, marine, urejena smučišča, golf igrišča itd.;

- kulturne: zgodovinske značilnosti, folklora, religija, umetnost, gledališča in muzeji; $v$ to skupino sodijo tudi posebni dogodki, festivali in srečanja;

- socialne: poseben način življenja lokalnega prebivalstva ter njihov jezik in možnosti druženja z njimi. 
Načrtovanje turističnih destinacij je proces, ki se ga lahko lotevamo $s$ prostorskega in $\mathrm{z}$ vsebinskega vidika. Pri prostorskem vidiku bomo upoštevali geopolitične značilnosti potencialne turistične destinacije, medtem ko vsebinski vidik upošteva razpoložljive turistične potenciale (vire). Prostorski vidik predvideva, da načrtovalci in razvijalci turistične destinacije najdejo urbanistične rešitve, ki bodo omogočale nemoteno delovanje destinacije kot zaključene geografske enote (Khan, Olsen in Tugur 1993). Eden izmed načinov iskanja možnosti je model primerjave virov, ki po posameznih območjih ugotavlja razpoložljive vire in možnosti njihove povezave s turistično ponudbo. Kot navajajo Khan, Olsen in Tugor (1993), je destinacija v želji, da izpolni pričakovanja tako turistov kot investitorjev in omogoči relativno nemoteno življenje domačinom, razdeljena na štiri osnovne geografske enote oz. dele:

- privlačni (atraktivni) predel: bodisi v predelu občine oz. v primernem bližnjem območju, saj ta del turistom predstavlja privlačno silo;

- bivalno oz. stanovanjsko območje: tu se proizvajajo osnovne turistične storitve, prav tako je vzpostavljena varnostna mreža (gasilci, zdravniška pomoč, policija), trgovine, komunalna mreža itd.; vse storitve so namenjene turistom in lokalnemu prebivalstvu;

- povezovalni transportni pas: $\mathrm{v}$ tem okolju deluje moteče, a je nujno potreben za dostop do vseh omejenih elementov destinacije;

- glavni transportni koridor: povezuje destinacijo s tržišči in z drugimi destinacijami.

Prebivalci destinacije se zavedajo (Uran in Juvan 2009, 200), da uspešen razvoj turizma ni možen brez pestre in konkurenčne turistične ponudbe. Hkrati se zavedajo pomena varovanja okolja pri razvoju turizma. Od razvoja turizma si prebivalci destinacije obetajo predvsem ugodnosti iz naslova turistične infrastrukture, ki jo pod ugodnejšimi pogoji želijo uporabljati tudi sami.

$\mathrm{Na}$ turističnem trgu je prisotna čedalje večja konkurenca med posameznimi turističnimi destinacijami. Globalna turistična konkurenca med turističnimi destinacijami postaja čedalje pomembnejša zaradi vzpona novih turističnih destinacij in sprememb glede želja in okusov turistov, ki postajajo čedalje bolj informirani, vse težje pa je zadovoljiti tudi njihove želje in potrebe na področju turizma. Pritiske konkurence občutijo tudi že tradicionalne turistične destinacije (Nemec Rudež in Bojnec 2007, 34). 


\section{Ponudniki turističnih proizvodov}

Poslovni subjekti (gospodarske družbe, ustanove javnega in zasebnega sektorja) so temeljni nosilci turistične dejavnosti. Poslovni subjekti so pri oblikovanju turistične ponudbe svobodni in nosijo vso poslovno odgovornost za svoje poslovne odločitve. Poslovni subjekti svoj podjetniški razvoj gradijo na poslovnih interesih, ki jih usklajujejo na lokalni in regionalni ravni v skladu z razvojnimi usmeritvami širših turističnih območij. Lastniška struktura in managerski sistemi v turističnih podjetjih se postopoma normalizirajo in omogočajo kakovostnejši podjetniški razvoj ter večjo konkurenčno učinkovitost slovenskih turističnih podjetij.

\section{Vloga turističnih agencij in organizatorjev turističnih potovanj}

Turistične agencije in organizatorji turističnih potovanj imajo med poslovnimi subjekti s področja turizma zelo pomembno vlogo. Pomembno je povečanje njihove aktivne vloge pri oblikovanju in trženju integralnih turističnih proizvodov turističnih destinacij na lokalni ravni v Sloveniji, pri trženju posebnih integralnih turističnih proizvodov in pri trženju celovite turistične ponudbe na tujih trgih. Za uspešno izvajanje vloge turističnih agencij in organizatorjev potovanj je bistvenega pomena njihovo konstruktivno sodelovanje in povezovanje s Slovensko turistično organizacijo (Vlada RS 2002, 60).

Osnovne funkcije naših turističnih agencij v nadaljnjem razvoju našega turizma, izhajajoč iz problema razvoja turizma, so (Rešetar 1981, 26):

- razvoj turistične ponudbe $\mathrm{v}$ destinaciji in njenih povezav $\mathrm{s}$ svetovnim tržiščem;

- organizacija dopusta za domače turiste;

- prodaja turističnih proizvodov, iz katerih je posamezna turistična destinacija sestavljena.

T. Krašna (2006) kot osnovno funkcijo turistične agencije opredeljuje posredovanje turističnih storitev, ki pomeni prodajo in rezervacijo pavšalnih proizvodov, hotelskih storitev, vozovnic in vstopnic. Turistična agencija sprejema in posreduje tudi plačila turističnih storitev za zastopane proizvajalce (Krašna 2006, Io). Poleg osnovne funkcije turistične agencije opravljajo še druge storitve: iskanje kupcev, svetovanje kupcu, svetovanje organizatorjem potovanj, skrb za kupce pred odhodom v destinacijo in pri povratku iz nje, sprejemanje in posredovanje pritožb kupcev, druge storitve, kot npr. menjavanje valut, urejanje zavarovanj, pridobivanje vizumov in potovalnih čekov, organiziranje in prodajanje potovanj po naročilu, prodajanje letalskih vozovnic. 
Pri razvoju turizma imajo turistične agencije pomembno vlogo, saj se jih veliko poleg emitivnega turizma ukvarja tudi z receptivnim turizmom, ki bistveno poveča prodajo posameznih izdelkov (spominki) in storitev (nastanitvene kapacitete, obisk prireditev) v Sloveniji, kar vpliva na povečanje domače potrošnje (Kaluža 2013a).

$\mathrm{Na}$ turističnem trgu je ponudba turističnih aranžmajev čedalje večja in tudi raznolika, vse dalj od turista, vse bolj v nekih neznanih območjih, želje turistov pa so vse večje, vse različnejše. Problem preglednosti trga v veliki meri rešujejo specializirani zastopniki (Planina 1996, 175). To so v prvi fazi turistične agencije, ki se z razvojem vse bolj preoblikujejo v velike organizatorje potovanj in tour operatorje, ki imajo na turističnem trgu pomembno vlogo.

Osnovna enota turistične ponudbe je turistični proizvod, ki je pretežno kombinacija fizičnega proizvoda in storitve. Storitve imajo štiri pomembne značilnosti, po katerih se razlikujejo od fizičnih proizvodov in odločilno vplivajo na njihovo trženje (Krašna 2002, 13): neotipljivost, neločljivost proizvodnje in potrošnje, nestalnost (variabilnost, heterogenost) in neobstojnost (kratkotrajnost storitev in minljivost).

Za ponudnike turističnih storitev, predvsem za turistične agencije, je značilno, da morajo veliko pozornosti nameniti trženju storitev, ki ima zlasti naslednje značilnosti (Rojšek 1995, 82):

- neotipljivost: storitve si ne moremo ogledati, poskusiti, preizkusiti, poslušati, poduhati ipd., preden jo kupimo, oz. si rezultata storitve ne moremo ogledati že pred nakupom, večkrat ga niti ne moremo prav določno napovedati;

- neločljivost proizvodnje storitve od njene porabe: ko gre za izdelek, je praviloma tako, da ga najprej proizvedemo, nato uskladiščimo, pripeljemo po različnih prodajnih kanalih h kupcu, ki ga porabi takoj po nakupu ali pa enkrat kasneje, medtem ko gre pri večini storitev za hkratno proizvodnjo in porabo;

- spremenljivost kakovosti storitve: kakovost storitve je zelo težko nadzorovati, toliko bolj tedaj, ko je sodelovanje odjemalca ključnega pomena zanjo; končni izid storitve se tako pogosto razlikuje glede na to, kdo jo opravi, glede na odjemalce in včasih celo glede na to, $v$ katerem delu dneva je bila opravljena;

- kratka življenjska doba storitve: za storitev lahko rečemo, da je lahko pokvarljivo blago, zato je ni mogoče skladiščiti; prazen sedež na avtobusu/letalu pomeni izgubo prodaje za vedno. 
Burkart in Medlik (1975, 132) opredeljujeta turistični proizvod z vidika turista kot celotno doživetje od trenutka, ko zapusti kraj stalnega prebivališča, do trenutka, ko se vrne vanj. Turistični proizvod je pravilnejše opredeliti kot sestavljen proizvod, saj je smiselna tudi njegova opredelitev z vidika individualnega proizvajalca (Mihalič 1999,64 ), saj posamezni turistični proizvajalci, letalske družbe, muzeji, podjetja »rent a car« pojem turistični proizvod zožujejo na proizvod, ki ga proizvajajo in prodajajo. $Z$ vidika proizvajalca je tako delni turistični proizvod posamezna storitev ali skupek več storitev, ki jih proizvaja oz. prodaja. Pavšalni proizvod je standardiziran paket storitev, ki ga sestavljata najmanj dve potovalni storitvi. Pavšalni proizvod proizvedejo vnaprej za neznanega kupca in za trg, ki ga razpršijo $\mathrm{v}$ tiskanih ali drugih medijih ter nudijo po javno objavljeni pavšalni ceni tako, da cene posameznih v paket povezanih turističnih storitev niso razpoznavne (Mihalič 1999,65$)$.

Rešetar $(1981,72)$ poudarja vrstni red nalog pri organiziranju pavšalnih aranžmajev $\mathrm{z}$ vključenim bivanjem $\mathrm{v}$ destinaciji: izbira destinacije, priprava programa, dogovor o zakupu hotelskih nastanitev (alotmajska pogodba), dogovor $s$ tujo in $\mathrm{z}$ domačo turistično agencijo, oblikovanje prodajne cene aranžmajev, trženje programa, najava gostov - »rooming « lista in obračun izvedenega aranžmaja.

Pri poslovanju turističnih agencij je pomemben tudi prihodkovni management, ki označuje celo vrsto trženjskih in managerskih aktivnosti $\mathrm{v}$ storitveni dejavnosti. Njegov cilj je v maksimiranju prihodka na osnovi ustrezne tržne segmentacije in optimalne razporeditve minljivih storitev, kot so letalski sedeži, hotelske postelje, avtomobili za najem itd. Gre za posebno tehniko (Mihalič 2000), ki pomaga podjetju, da maksimira prihodke od prodaje storitev, za katere sta $\mathrm{v}$ prvi vrsti značilni nezmožnost skladiščenja (minljivost zalog) in fiksna zmogljivost. Podjetje vpliva na dve spremenljivki: ceno in količino - to je na dejavnika celotnega prihodka. Management prihodka se nanaša na odločitve o cenah in stopnji zasedenosti zmogljivosti tako, da maksimira celotni prihodek (izplen) v nekem razdobju. Kadar je povpraševanje večje od ponudbe, naj podjetja, ki se ukvarjajo z minljivimi storitvami, povišajo ceno storitev, kadar pa je ponudba večja od povpraševanja, naj podjetja znižajo ceno, nudijo boljše plačilne pogoje, da kratkoročno pokrijejo vsaj stroške poslovanja ali imajo nižji izpad prihodkov, kot bi ga imela sicer, saj se moramo zavedati, da obstajajo določeni fiksni stroški, ki jih je treba plačati ne glede na izkoriščenost storitvenih kapacitet (Kaluža 20I2), kot npr. stroški zavarovanja objektov, najema poslovnih prostorov, čarterskih letov, internetnega priključka itd. 
$\mathrm{V}$ zadnjem času se je na konkurenčnem turističnem trgu pojavila možnost t. i. »rezervacij v zadnji minuti (last minute) «. Organizatorji potovanj, ki navadno dva tedna ali en teden pred izvedbo določenega pavšalnega programa ugotovijo, da že zakupljene zmogljivosti (letalske, hotelske) niso v celoti prodane, ta pavšalni proizvod ponudijo po močno znižani ceni. Omenjena ponudba je dostopna tudi pri turističnih posrednikih (Mihalič 1997,24$)$.

Turistična podjetja morajo $\mathrm{v}$ nesorazmerno veliki meri skrbeti tudi za informacijsko in propagandno dejavnost, ker turizem večinoma še nima visoke stopnje nujnosti. Pri tem ne gre samo za propagandno dejavnost posameznih podjetij, pač pa za splošno propagando, ki propagira ali informira potencialne turiste o določenem kraju, regiji ali državi. Če je bila nekoč to naloga proračunov, pri nas to dejavnost v veliki meri posredno financirajo turistična podjetja, pri čemer naj bi bilo doseženo načelo, naj vsakdo za to prispeva toliko sredstev, kolikor ima koristi od turizma, neposredno ali posred no (Planina 1997, 179).

\section{Turistični kraj in turistična regija}

Turistični kraj in turistična regija imata zelo pomembno vlogo, saj turistične agencije $\mathrm{v}$ svoji ponudbi vključijo turistične proizvode, ki so povezani s turističnim krajem in turistično regijo; pri tem imajo turistične agencije zelo pomembno vlogo. $V$ turističnem kraju in turistični regiji ne živijo samo ljudje, ki imajo v njej svoje prebivališče ali npr. službo, temveč so tam tudi takšni, ki pridejo na izlet, tam prebivajo določeno število dni zaradi osebnih, službenih ali drugih razlogov. Turistične agencije s svojo ponudbo pomembno prispevajo $\mathrm{k}$ sprejemanju izletnikov, turistov iz drugih krajev tam, kjer turistični kraj in turistična regija nista območji, kjer bi izletnik, turist imel stalno prebivališče.

Turistični kraj je ena izmed možnih opredelitev destinacije. Predstavlja celoto gospodarskih in negospodarskih dejavnosti, ki so na nekem ožjem geografskem območju namenjene turistom. Turistični kraj opredeljujemo kot naselje (lahko tudi kot več naselij skupaj ali samo kot del naselja), ki je dostopno obiskovalcem in ima naravne, kulturne ali druge zanimivosti, ki se izrabljajo v turistične namene, in ki ima ustrezne turistične objekte in organizacije (Mihalič in Planina 2002, 17 I).

Po tem pojmovanju mora vsak turistični kraj ustrezati naslednjim glavnim pogojem (Mihalič in Planina 2002, 171):

- biti mora dostopen: imeti mora razvito komunikacijsko mrežo; 
- imeti mora za turiste zanimive objekte oz. elemente: naravne in kulturno-zgodovinske zanimivosti, prireditve itd.; te morajo redno privlačiti turiste bodisi skozi vse leto ali samo v določenem času;

- imeti mora receptivne objekte in organizacije, ki po eni strani skrbijo za vrednotenje zanimivosti, po drugi strani pa proizvajajo take turistične proizvode, ki jih zahtevajo turisti in ki jim omogočajo nastanitev in različne oblike rekreacije v kraju; sem sodijo nastanitveni objekti, drugi storitveni objekti, kopališča, parki itd.

Vrste turizma so vselej odvisne od prostorskih možnosti in naravnih značilnosti določenega prostora. Ko naravne zanimivosti izkoriščamo v turistične namene, se pojavijo in razvijajo gospodarske dejavnosti. $\mathrm{Na}$ ta način naravne regije prevzemajo posebne značilnosti ekonomskih regij, saj naravne razmere dajejo možnosti za razvoj turizma, ta pa zahteva tudi razvoj gospodarskih dejavnosti, ki ekonomsko ovrednotijo naravne zanimivosti. Zato moramo šteti turistične regije za posebno vrsto ekonomskih regij (Mihalič in Planina 2002, 176). 



\section{Uspešnost poslovanja v turističnih agencijah}

Uspešnost poslovanja turistične agencije lahko merimo z različnimi kazalci; ne glede na izbiro kazalca je pomembno, da pri tem ugotavljamo rezultat poslovanja, ki ga primerjamo z zastavljenimi cilji.

Pri preučevanju uspešnosti poslovanja $\mathrm{v}$ turističnih agencijah smo se osredotočili na $\mathrm{v}$ anketnem vprašalniku zastavljena vprašanja $\mathrm{v}$ zadnjem delu ankete, kjer smo zaprosili lastnike/managerje/vodje turističnih agencij in njihovih poslovalnic, da odgovorijo na vprašanja $\mathrm{v}$ zvezi z uspešnostjo poslovanja njihove turistične agencije/poslovalnice. Njihove odgovore smo potem primerjali z uradnimi podatki, objavljenimi na spletnem brskalniku (www. google.com, spletna stran bizi.si).

Preučevanje uspešnosti poslovanja se je nanašalo na:

- donosnost: ROI, ROA in ROE;

- rast: prihodke od prodaje, povečanje števila zaposlenih, povečanje tržnega deleža na domačem in tujem trgu ter dobiček;

- dobičkonosnost TA (na vprašanji so odgovarjali le $1 / \mathrm{m} / \mathrm{v}$ ): $\mathrm{z}$ vsemi konkurenčnimi turističnimi agencijami in $s$ turističnimi agencijami, ki so na trgu enako število let in v enaki fazi razvoja.

B. Bradač Hojnik (2009) ugotavlja, da zunanje izvajanje storitev prispeva $\mathrm{k}$ uspešnosti podjetij kljub temu, da na uspešnost vplivajo tudi drugi dejavniki. Pri tem je pomembno izločanje ključnih in podpornih dejavnosti podjetij. 
Rast

Rast turistične agencije je odvisna od številnih dejavnikov, eden izmed najpomembnejših dejavnikov pa je vsekakor potencial, ki ga ima turistična agencija za rast. Zavedati se moramo, da je na trgu veliko turističnih agencij in želja po rasti predstavlja eno izmed pomembnejših meril uspešnosti poslovanja številnih turističnih agencij na trgu. Nekatere turistične agencije so že začele poslovati tudi na tujem trgu, še zlasti na področju receptivnega turizma, ki predstavlja zelo pomembno vlogo pri prihodu tujih izletnikov, turistov v Slovenijo. Tu ima čedalje večjo vlogo tudi država, ki promovira Slovenijo kot turistično destinacijo s številnimi naravnimi in kulturnimi znamenitostmi (Kaluža 2006).

$\mathrm{Za}$ rast podjetja je predvsem $\mathrm{v}$ storitvenih panogah pomembno zadovoljstvo zaposlenih (Auer Antončič 2012, 239).

Rast (Drnovšek 2002) je v ekonomski teoriji in politiki med najpogosteje opazovanimi spremenljivkami. Pojem se pogosto uporablja v dveh primerih: včasih pomeni preprosto povečanje obsega npr. prihodkov, izvoza, števila zaposlenih, pogosto pa rast pomeni celoten razvoj, podoben biološkemu razvoju.

\section{Rast prihodkov od prodaje}

Gledano z vidika finančnega kazalca smo preučevali rast prihodkov od prodaje (spremembe $\mathrm{v}$ stalnih cenah), ki se nanaša na prihodke od prodaje v obdobju 20II-20I3 (drugo preučevano obdobje) glede na obdobje 2008-2010 (prvo preučevano obdobje), in ugotavljali, ali so se prihodki od prodaje v drugem preučevanem obdobju glede na prvo povečali do $5 \%$, nad 5 do $10 \%$, nad 10 do $20 \%$, nad 20 do $35 \%$, nad $35 \%$ ali so se prihodki od prodaje v drugem preučevanem obdobju glede na prvo zmanjšali do $5 \%$, nad 5 do $10 \%$, nad 10 do $20 \%$, nad 20 do $35 \%$, nad $35 \%$ ali pa so prihodki od prodaje $v$ drugem preučevanem obdobju glede na prvo obdobje ostali dokaj enaki. Navedeno smo preučevali tudi iz uradnih podatkov za omenjeni obdobji, objavljenih na spletnem brskalniku (www.google.com, spletna stran bizi.si), in pridobljene podatke primerjali.

\section{Povečanje števila zaposlenih}

Pridobivanje in izbira sodelavcev temeljita na podrobnem opisu delovnih nalog in zahtev delovnega mesta, ki jih mora kandidat izpolnjevati, da bi uspešno izvajal vsa opravila, ki sestavljajo delovno nalogo določenega delovnega mesta. Poslovna uspešnost je neposredno odvisna od uspešnega opravljanja delovnih nalog $\mathrm{v}$ prodaji, zato vodstva podjetij izbiri prodajnega osebja posvečajo posebno pozornost (Potočnik 2002, 385). 
Zaposleni so ključni dejavnik, ki omogoča poslovanje podjetij. Kljub razvoju tehnologije in drugih dejavnikov, ki v določenem delu nadomeščajo fizično silo, $v$ določenem delovnem procesu pa celo skoraj v celoti, so zaposleni še vedno nenadomestljiv dejavnik poslovanja podjetij. $V$ našem primeru smo rast podjetja preučevali tudi za preučevani obdobji, in sicer smo ugotavljali, ali se je število zaposlenih v drugem preučevanem obdobju glede na prvo obdobje povećalo do $5 \%$, nad 5 do $10 \%$, nad 10 do $20 \%$, nad 20 do $35 \%$, nad $35 \%$ ali se je število zaposlenih v drugem preučevanem obdobju glede na prvo obdobje zmanjšalo do $5 \%$, nad 5 do $10 \%$, nad ro do $20 \%$, nad 20 do $35 \%$, nad $35 \%$ ali pa je število zaposlenih v drugem preučevanem obdobju glede na prvo obdobje ostalo dokaj enako. Pridobljene podatke smo primerjali z uradnimi podatki za omenjeni obdobji, objavljenimi na spletnem brskalniku (www.google.com, spletna stran bizi.si).

\section{Povečanje tržnega deleža na domačem in tujem trgu}

Z globalizacijo mednarodnega poslovanja, ko se izgubljajo ali zamegljujejo meje med državami ali regionalnimi območji in s tem klasična definicija izvora izdelka, se spreminjajo tudi dimenzije procesa konkuriranja. Globalni trg, s katerim se danes soočajo podjetja v svetovnem ekonomskem prostoru, je nastal $\mathrm{v}$ okviru večplastnega in vseobsežnega svetovnega pojava - globalizma. Definicija globalizma (internacionalizma, transnacionalizma) je sicer dokaj široka, na ekonomskem področju pa pomeni predvsem krepitev zavesti o potrebi po odprtosti k mednarodnemu (svetovnemu) trgu. Globalni trg je ena izmed posledic znanstveno-tehnološkega razvoja, ki je omogočil postopen prehod v postindustrijsko, inovativno in intelektualno družbo, ta pa presega meje nacionalnih držav.

Tržni delež je del trga, na katerem je neko podjetje prisotno in ga lahko ugotavljamo z deležem (\%) nekega podjetja tako na domačem kot tudi tujem trgu. Trg je prostor, kjer se srečata ponudba in povpraševanje $\mathrm{z}$ namenom, da bi se izmenjalo določeno število dobrin (blaga ali storitev) po določeni ceni in pod določenimi plačilnimi pogoji. Turistične agencije se že vrsto let ukvarjajo z emitivnim in receptivnim turizmom in povečanje, zmanjšanje ali pa dokaj enako stanje tržnega deleža posamezne turistične agencije lahko pripišemo številnim dejavnikom, kot npr.: vstopu Slovenije v Evropsko unijo in druge integracije, razvoju turističnih destinacij, boljšim plačilnim pogojem za povpraševalce po turističnih aranžmajih ipd. Vokviru naše raziskave smo preučevali spremembo tržnega deleža tako na domačem kot tudi na tujem trgu. $\mathrm{V}$ obeh primerih smo spremembo $\mathrm{v}$ drugem preučevanem obdobju glede na prvo obdobje primerjali v odstotkih, in sicer povečanje tržnega deleža do $5 \%$, nad 5 do $10 \%$, nad Io do 
$20 \%$, nad 20 do $35 \%$, nad $35 \%$, zmanjšanje tržnega deleža do $5 \%$, nad 5 do $10 \%$, nad 10 do $20 \%$, nad 20 do $35 \%$, nad $35 \%$ ali je tržni delež v drugem preučevanem obdobju glede na prvo obdobje ostal dokaj enak. Odgovorov, ki se nanašajo na spremembo tržnega deleža na domačem in tujem trgu, ni bilo mogoče primerjati z uradnimi podatki na bizi.si, saj teh podatkov tam ni.

\section{Dobiček}

Dobiček opredeljujemo kot pozitivno razliko med celotnimi prihodki in odhodki v določenem preučevanem koledarskem obdobju. Dobiček je eden izmed glavnih dejavnikov, zaradi katerih posameznik ustanovi neko podjetje. Seveda pa kot ekonomski kazalnik ni vedno glavni cilj vseh lastnikov podjetij. Za ugotavljanje dobička kot informacije je pomembno, kakšna je njegova izrazna moč. Nas je pri ugotavljanju dobička zanimalo, ali se je dobiček v obdobju 20 I-20I3 glede na obdobje 2008-20ı povečal, in sicer do $5 \%$, nad 5 do $10 \%$, nad Io do $20 \%$, nad 20 do $35 \%$, nad $35 \%$, oz. zmanjšal, in sicer do $5 \%$, nad 5 do $10 \%$, nad ıo do $20 \%$, nad 20 do $35 \%$, nad $35 \%$, ali je dobiček v obdobju 20 I I-2013 glede na obdobje 2008-2010 ostal dokaj enak.

\section{Donosnost}

Pri donosnosti poslovanja turističnih agencij smo preučevali donosnost vloženih sredstev - torej naložbe, ki so razmerje med dobičkom in sredstvi, vloženimi v naložbo (angl. return on investments - ROI), dobiček glede na sredstva ali obveznosti do virov sredstev (angl. return on assets - ROA) kot razmerje med dobičkom in vloženimi sredstvi delničarja (lastnika), kar pomeni, da gre za donosnost lastnega kapitala, ter kot razmerje med dobičkom in trajnim kapitalom oz. med dolgoročnimi obveznostmi sredstev, kar pomeni, da gre za donosnost vloženega kapitala (angl. return on equity - ROE) (Bojnec idr. 2007, 237).

\section{Donosnost investicije (ROI)}

Opomba: praviloma se dobičku prištevajo tudi obresti od dolžniškega kapitala.

\section{Dobiček glede na sredstua (ROA)}

Dobiček glede na sredstva ali obveznosti do virov sredstev (angl. return on assets - ROA) kot razmerje med dobičkom in vloženimi sredstvi delničarja (lastnika), kar pomeni, da gre za donosnost lastnega kapitala. 


\section{Donosnost vloženega kapitala (ROE)}

Gre za donosnost vloženga kapitala (angl. return on equity - ROE) kot razmerje med dobičkom in kapitalom podjetja.

\section{Dobičkonosnost TA}

$\mathrm{Z}$ raziskavo smo lastnike, managerje in vodje $(1 / \mathrm{m} / \mathrm{v})$ anketirali tudi glede dobičkonosnosti TA v primerjavi:

- $\quad z$ vsemi konkurenćnimi turističnimi agencijami, $\mathrm{ki} \mathrm{jih} \mathrm{l} / \mathrm{m} / \mathrm{v}$ poznajo, in primerjali drugo preučevano obdobje s prvim preučevanim obdobjem, in sicer, ali je bila dobičkonosnost TA nekoliko nižja, približno enaka, zmerno višja, občutno višja ali izjemno višja;

- sturističnimi agencijami, $\mathrm{ki} \mathrm{jih} \mathrm{l} / \mathrm{m} / \mathrm{v}$ poznajo, ki so na trgu enako stevilo let in $v$ enaki fazi razvoja, in primerjali drugo preučevano obdobje s prvim preučevanim obdobjem, in sicer, ali je bila dobičkonosnost TA nekoliko nižja, približno enaka, zmerno višja, občutno višja ali izjemno višja. 



\section{Predhodne raziskave na obravnavanem področju}

Po pregledu strokovne in znanstvene literature s področja raziskovanja vpliva človeškega kapitala in organizacijske klime na uspešnost poslovanja turističnih podjetij smo ugotovili, da raziskovanje omenjenih vsebin predstavlja velik izziv.

V Sloveniji je bilo po osamosvojitvi države v devetdesetih letih prejšnjega stoletja do danes pripravljenih nekaj strategij razvoja slovenskega turizma, strategij razvoja turizma posameznih turističnih destinacij, kvalifikacijska struktura na področju gostinstva, hotelirstva in turizma in še nekaj mikro analiz možnosti razvoja turizma v Sloveniji. Posamezne analize pa se še niso dotaknile preučevanja turističnih agencij in njihovih poslovalnic kot deležnikov razvoja slovenskega turizma, kjer bi raziskovali vpliv človeškega kapitala in organizacijske klime na uspešnost poslovanja turističnih agencij.

Nekaj po svetu izvedenih raziskav je ugotavljalo posamezne konstrukte na vpliv uspešnosti poslovanj s področja storitvenih organizacij.

Pri pregledu strokovne in znanstvene literature s področja raziskovanja vpliva človeškega kapitala in organizacijske klime na uspešnost poslovanja turističnih agencij nismo zasledili nobene raziskave, ki bi preučevala omenjeno. Zasledili smo nekaj raziskav vpliva znanja na poslovno uspešnost podjetja, na področju turizma pa predvsem raziskave uspešnosti poslovanja hotelskih podjetij.

$S$ področja turizma, kjer so turistične agencije s svojimi poslovalnicami tudi eden izmed deležnikov, ki sooblikujejo turistično gospodarstvo in kjer so zaposleni s svojim človeškim kapitalom in organizacijsko kli- 
mo pomemben dejavnik, ki vpliva na uspešnost poslovanja, se do sedaj z empiričnim raziskovanjem ni ukvarjal nihče, vsaj ne na akademski ravni.

D. Gomezelj Omerzel (2008) ugotavlja pomen znanja zaposlenih, znanje podjetnika in management zaposlenih za poslovno uspešnost $\mathrm{v}$ malih in srednje velikih podjetij z oblikovanjem dveh poddimenzij, in sicer rasti in dobičkonosnosti. Avtorica je $\mathrm{z}$ raziskavo potrdila glavno tezo, vezano na model znanja, in sicer da je znanje večdimenzionalen konstrukt, ki vsebuje dimenzije znanja zaposlenih, znanje podjetnika in management znanja. V skladu s teoretičnimi koncepti je avtorica pričakovala, da bodo dobili dimenzije zmožnosti, odnos do dela in inovativnost, dodatno pa sta se pojavili še dve dimenziji, kar je skupaj pet dimenzij, ki jih je smiselno pojasniti. To so dimenzije inovativnost in volja po izobraževanju, odnos do dela, usposobljenost za delo, izobrazba ter delovne izkušnje. Raziskava je bila sicer geografsko omejena le na Slovenijo, vzorec je obsegal 168 enot, saj sta bili prisotni časovna in materialna omejenost. Avtorica v raziskavi trdi, da so na tem področju razvili novo teorijo znanja v podjetjih, njegovih dimenzij, poddimenzij in pojasnjevalnih spremenljivk, kjer gre za konstrukcijo integriranega modela znanja v podjetništvu, ki vzpostavlja povezave tudi med posameznimi dimenzijami.

T. Mihalič idr. (2009) so v zvezi z uspešnim poslovanjem hotelskih podjetij v Sloveniji poudarili, da morajo vsa podjetja zagotavljati ekonomsko uspešno poslovanje, ki pa je še vedno pogosto povezano s tradicionalnim poslovnim izidom, prevladujoči načini merjenja razvoja pa temeljijo predvsem na ekonomskih indikatorjih (na sistemu nacionalnih računov, bruto domačem proizvodu, profitnih izkazih itd.). Koncept trajnostnega razvoja v turizmu je po mnenju avtorjev predvsem predmet obravnave na področju destinacij kot zaokroženih celic trajnostnega razvoja. Ker je razvoj trajnostnega poimenovanja uspešnosti hotelskih podjetij vezan na različna področja (ekonomika in finance, trženje, turistična ekologija), so $\mathrm{z}$ uveljavljenim strokovnim in političnim dialogom indikatorje združili v tri sklope: ekonomski indikatorji, kamor spadajo finančni in trženjski indikatorji, ki merijo zadovoljstvo potrošnikov in so osnova za management zadovoljstva ter posredno finančne uspešnosti poslovanja, kazalniki, s katerimi se ukvarja delovno področje ekonomike, financ in trženja; okoljski indikatorji, ki združujejo indikatorje uporabe naravnih virov ter skrb zanje v širšem smislu in skrb za biološko raznovrstnost, indikatorji, ki zadevajo področje turistične ekologije in trajnostnega turizma; družbeni indikatorji, ki se nanašajo na odnos do družbenega okolja, sodelovanje z vsemi deležniki in tudi politično dimenzijo poslovanja in sode- 
lovanja. Tudi te kazalnike so preučili z ekspertnim znanjem s področja turistične ekologije in trajnostnega turizma.

Vidic (2OI2) poudarja, da je pri samem procesu izobraževanja in usposabljanja, pretakanju tacitnega in eksplicitnega znanja treba upoštevati posebnosti posameznika, posredno vplivati na njegovo naravnanost in ga navdušiti za kreiranje novega znanja.

Noe, A. D. M. Clarke in Klein (20I4) ugotavljajo, da je človeški kapital ključ do konkurenčne prednosti podjetij. Učenje na podlagi formalnega usposabljanja in razvojnih programov, neformalno učenje in izmenjava znanja vplivajo na razvoj človeškega kapitala. Gre za selektivni pregled raziskav o učenju, ki se pojavlja v različnih oblikah. Ugotavljajo, kako učenje deluje na posameznike, skupine in na organizacijski ravni. Pomembni so oblika in zasnova učenja ter omogočanje učenja na delovnem mestu, kar širi obseg učnih rezultatov. Danes se organizacije soočajo z gospodarskimi, globalnimi, s tehnološkimi in tržnimi izzivi za svojo konkurenčnost. 



\section{O raziskavi: kvantitativna analiza vpliva dejavnikov uspešnosti poslovanja}

$\mathrm{V}$ empiričnem delu raziskave predstavljamo ciljno populacijo in vzorčenje, metodo zbiranja podatkov s pilotno raziskavo, vzorec, metode analize podatkov in testiranja hipotez, $\mathrm{v}$ analizo vključene spremenljivke, obdelavo in analizo podatkov, interpretacijo rezultatov ter strukturni model.

\section{Ciljna populacija in vzorčenje}

Ciljno populacijo smo določili na naslednji način:

- $\quad \mathrm{v}$ raziskavo so bile vključene tiste turistične agencije in njihove poslovalnice (306 turističnih agencij in 84 njihovih poslovalnic vseh turističnih agencij je 520 , po podatkih s spletne strani bizi.si $\mathrm{z}$ dne 8 . avgusta 2014 pa so imele 926 zaposlenih), ki so imele po podatkih na spletnih straneh Gospodarske zbornice Slovenije z dne 8. avgusta 2014 glavno dejavnost po SKD:

- 79.120 - dejavnost organizatorjev potovanj ali

- 79.110 - dejavnost potovalnih agencij ali

- 79.900 - rezervacije in druge s potovanji povezane dejavnosti;

- turistične agencije, ki so imele licenco, a niso bile vključene $\mathrm{v}$ raziskavo $(520-306=214$ turističnih agencij z licenco), niso opravljale ene izmed navedenih dejavnosti kot glavno dejavnost in njihova vključenost $\mathrm{v}$ raziskavo posledično ne bi odražala namena in ciljev raziskave.

Vzorec je vključeval celotno ciljno populacijo in je bil odvisen od števila respondentov, ki so odgovorili na anketni vprašalnik. Predpostavljali smo, da bo sodelovalo I5-20 \% od vseh 926 zaposlenih; pričakovali smo 
I 85 vrnjenih anketnih vprašalnikov, kar bi bil naš vzorec, uporabljen v empirični analizi. V raziskavi je sodelovalo 336 respondentov od 926, kar predstavlja 36,29\% ciljne populacije iz ı03 TA (od 306), kar predstavlja 33,66 \% celotne ciljne populacije. To pomeni, da lahko rezultate empirične raziskave $\mathrm{z}$ veliko verjetnostjo posplošimo na celotno populacijo.

\section{Metoda zbiranja podatkov}

Kot tehniko anketiranja smo uporabili anonimno anketiranje prek elektronske pošte, ki je bilo opremljeno $\mathrm{z}$ dopisom o spletni raziskavi. $\mathrm{V}$ vprašalnik smo vključili spremenljivke iz konceptualnega modela, sociodemografska vprašanja ter značilnosti turističnih agencij in njihovih poslovalnic. Za vse stavčne trditve spletnega anketnega vprašalnika smo za namen zbiranja podatkov kvantitativne raziskave uporabili petstopenjsko Likertovo ocenjevalno lestvico strinjanja ali nestrinjanja, pri čemer so bili vsi odgovori istosmerni (višja ocena $\rightarrow$ večje strinjanje). Tovrstna vprašanja uporabljajo semantični diferencial, kar pomeni, da respondent označi točko, ki predstavlja njegovo mnenje. Lastniki/managerji/vodje turističnih agencij in njihovih poslovalnic ter drugi zaposleni so tako označili, kako močen je vpliv dejavnikov človeškega kapitala in organizacijske klime na uspešnost poslovanja turističnih agencij. Pri tovrstnem ocenjevanju se lahko pojavi tudi slabost, saj gre za veliko subjektivnost.

\section{Pilotna raziskava za pripravo spletnega anketnega vprašalnika}

Za raziskavo smo pripravili spletni anketni vprašalnik. Vsaki spremenljivki smo dodelili primerno mersko lestvico. Pred izvajanjem spletne ankete smo izvedli pilotno raziskavo, $s$ katero smo preizkušali raziskovalni postopek, ki je bil predmet naše obsežnejše raziskave. V pilotno raziskavo, ki smo jo izvedli v Mariboru in Ljubljani, smo vključili štiri turistične agencije in po eno poslovalnico iz dveh turističnih agencij; poslovalnici nista bili iz prej omenjenih turističnih agencij. $\mathrm{V}$ pilotno raziskavo smo vključili enega lastnika iz dveh turističnih agencij, enega managerja turistične agencije, enega vodjo turistične agencije in pet drugih zaposlenih $\mathrm{v}$ teh turističnih agencijah, $\mathrm{v}$ dveh poslovalnicah turističnih agencij pa smo vključili dve vodji in tri zaposlene. $S$ pilotno raziskavo smo ugotovili, da je zelo smiselno pisno razložiti posamezne termine, ki so predmet raziskave (emitivni in receptivni turizem, ROA, ROE, ROI ipd.), saj s tem bistveno prispevamo $\mathrm{k}$ razumevanju anketnih vprašanj in posledično obstaja zelo velika verjetnost, da respondenti na posamezna anketna vprašanja odgovorijo tako, kot je značilno za njihovo turistično agencijo/poslovalnico. 
Nekatera vprašanja smo dopolnili in jih poudarili, preglednice pa prilagodili, da bi bilo na anketo možno odgovoriti z manj nejasnosti in da respondentov ne bi odvrnili od anketiranja. Vsi sodelujoči v pilotni raziskavi so poudarili, da so vprašanja vsebinsko dobra, dva izmed sodelujočih pa sta omenila, da je mogoče vprašanj malo preveč, zato smo nekatera vprašanja skrajšali, vendar smo bili še vedno pozorni na to, da smo ohranili vsebino, ki je bila predmet našega raziskovanja.

\section{Anketni vprašalnik}

Anketni vprašalnik je bil sestavljen iz naslednjih tematskih delov:

- prvi del: podatki o respondentu (spol, starost, status zaposlitve, stopnja izobrazbe, delovno mesto v turistični agenciji, število let zaposlitve v dotični turistični agenciji, skupno število let zaposlitve);

- drugi del: podatki o turistični agenciji (statusna oblika turistične agencije, število zaposlenih na tem prodajnem mestu, ali gre za turistično agencijo s sedežem, pri čemer respondent odgovarja, ali gre za poslovalnico turistične agencije, navede število let turistične agencije na trgu, vrsto licence za opravljanje dejavnosti);

- tretji del: človeški kapital v turističnih agencijah, ki smo ga preučevali kot odnos podjetja do izboljšanja človeškega kapitala, kar se nanaša na investicijo v znanje, vrsto znanj, usposabljanje, veščine, učenje posameznika in tima, učečo se organizacijo;

- četrti del: organizacijska klima (odnos do kakovosti, inovativnost in iniciativnost, strokovna usposobljenost in učenje, motivacija in zavzetost, notranje komuniciranje in informiranje, vodenje (delegiranje dela), notranji odnosi, poznavanje poslanstva in vizije ter ciljev, organiziranost, pripadnost organizaciji, razvoj kariere, nagrajevanje, zadovoljstvo zaposlenih);

- peti del: uspešnost poslovanja, ki smo jo preučevali z:

- donosnostjo: donosnost vloženih sredstev - torej naložb; gre za razmerje med dobičkom in sredstvi, vloženimi v naložbo (angl. return on investments - ROI), dobiček glede na sredstva ali obveznosti do virov sredstev (angl. return on assets - ROA) kot razmerje med dobičkom in vloženimi sredstvi delničarja (lastnika), kar pomeni, da gre za donosnost lastnega kapitala, ter kot razmerje med dobičkom in trajnim kapitalom oz. med dolgoročnimi obveznostmi sredstev, kar 
pomeni, da gre za donosnost vloženega kapitala (angl. return on equity - ROE);

- rastjo: prihodki od prodaje, povečanje števila zaposlenih, povečanje tržnega deleža na domačem in tujem trgu ter dobiček;

- dobičkonosnostjo TA: povprečna stopnja dobička iz celotnih sredstev, povprečna stopnja dobička iz lastniškega kapitala, dobičkonosnost podjetja $\mathrm{v}$ primerjavi z vsemi konkurenčnimi podjetji, ki jih respondenti poznajo, in dobičkonosnost $\mathrm{s}$ konkurenčnimi podjetji, ki so približno enake starosti in $\mathrm{v}$ enaki fazi razvoja.

\section{Potek raziskave}

$S$ pripravljenim anketnim vprašalnikom smo najprej izvedli pilotno raziskavo in anketni vprašalnik potem popravili glede na posredovane pripombe in priporočila. $\mathrm{V}$ začetku januarja 2015 smo začeli s telefonskimi klici, ker smo želeli najprej poklicati vse TA/poslovalnice, ki so predstavljale ciljno populacijo. TA, s katerimi smo vzpostavili stik, smo v drugi polovici januarja 2015 poslali spremni dopis o raziskavi z željo po sodelovanju. Prosili smo jih, da nam izpolnjeni anketni vprašalnik vrnejo do 6 . februarja 2015. TA, ki Io. januarja 2015 niso imele objavljene telefonske številke in/ali elektronskega naslova na spletnem brskalniku (www. google.si, spletna stran bizi.si), preko česar bi najlažje vzpostavili stik in jih prosili za sodelovanje $\mathrm{v}$ anketi, je bilo 27 . Tem smo anketni vprašalnik $s$ spremnim dopisom poslali po klasični pošti, kjer smo navedli tudi možnost sodelovanja preko spletne strani. Le 4 TA od 27 so izpolnjeni anketni vprašalnik vrnile po klasični pošti. 23 TA se kljub dvakratnemu klicu ni oglasilo, zato smo se za 8 TA odločili, da jim na njihovo mobilno številko pošljemo obvestilo, da bomo poslali anketni vprašalnik na njihov elektronski naslov. 3 TA so se s povratnim sporočilom zahvalile za poslani anketni vprašalnik, ostalim is TA, $s$ katerimi nismo uspeli vzpostaviti telefonskega stika, smo poslali anketni vprašalnik na njihov spletni naslov. 7 TA ni imelo več veljavnega elektronskega naslova, zato smo jih poklicali in posredovali so nam svoj novi elektronski naslov. 19 TA, ki smo jih poklicali, pa je sodelovanje $\mathrm{v}$ raziskavi zavrnilo.

Vnovič smo 9. februarja 2015 vsem TA (razen tistim 15, s katerimi nismo mogli vzpostaviti stika, ter tistim, ki so sodelovanje zavrnile) poslali dopis po elektronski pošti, $v$ katerem smo se iskreno zahvalili vsem TA/poslovalnicam, ki so spletni anketni vprašalnik izpolnili, tiste $1 / \mathrm{m} / \mathrm{v}$ 
in druge zaposlene, ki spletnega anketnega vprašalnika še niso izpolnili, pa zaprosili za sodelovanje in vračilo izpolnjenega anketnega vprašalnika do i2. februarja 2015 .

Pri načrtovanju vzorca TA/poslovalnic - 306 TA in 84 njihovih poslovalnic, ki so organizacijsko njihove poslovne enote -, torej od skupaj preučevanih $306 \mathrm{TA}$, ki so predstavljale celotno ciljno populacijo, je v anketi sodelovalo ı03 TA, kar znaša 33,66 \% celotne populacije. Te predstavljajo naš vzorec, na podlagi katerega smo izvedli nadaljnjo raziskavo o temeljnih tezi in hipotezah. Izmed 926 zaposlenih v teh TA/poslovalnicah, ki predstavljajo celotno ciljno populacijo, je sodelovalo 336 respondentov, kar predstavlja 36,29\% ciljne populacije, vključene v vzorec l/m/v, in drugih zaposlenih, ki so sodelovali v naši raziskavi.

Pred analizo podatkov smo vse podatke TA/poslovalnic, ki so bili izraženi v evrih in objavljeni na spletni strani bizi.si, 3. marca 2015 najprej deflacionirali na dan 31. december 2013, za kar smo uporabili cenovni indeks počitnic $v$ paketu. Podatke smo deflacionirali s pomočjo aplikacije, objavljene na spletni strani Statističnega urada RS.

\section{Metode analize podatkov in testiranje hipotez}

Zbrane podatke smo s pomočjo statističnih programov SPSS in AMOS obdelali in analizirali z naslednjimi statističnimi metodami:

- deskriptivno analizo;

- faktorsko analizo in metodo glavnih komponent;

- regresijsko in multiplo regresijsko analizo;

- metodami strukturnih enačb.

Vse primarno zbrane podatke smo najprej parcialno ocenili, nato pa so bile hipoteze testirane $\mathrm{z}$ naštetimi metodami. Temu je sledila skupna analiza $\mathrm{z}$ metodo strukturnih enačb. Po končani analizi podatkov smo podali ugotovitve glede testiranja hipotez.

Z deskriptivno analizo smo prikazali osnovne značilnosti vzorca (vzorec je vključeval celotno preučevano populacijo) in spremenljivk. Z multiplo regresijsko analizo smo analizirali vzročno-posledično povezanost med odvisnimi in neodvisnimi spremenljivkami. Pri analizi večjega števila spremenljivk smo uporabili faktorsko analizo in metodo glavnih komponent. S faktorsko analizo smo analizirali povezave med spremenljivkami, s katerimi smo skušali najti novo množico spremenljivk (manj kot je merjenih spremenljivk) - faktorje, ki predstavljajo, kar je skupnega opazovanim spremenljivkam. Faktorska analiza je metoda, s katero preverimo, kako dobro spremenljivke, ki jih merimo, predstavljajo neko 
manjše število konstruktov (Hair idr. 2009, 670). S to analizo želimo razčistiti svojo statistično učinkovitost (Hair idr. 2006, 750). Podobno kot pri faktorski analizi je cilj metode glavnih komponent ugotoviti, ali lahko skupne značilnosti med opazovanimi spremenljivkami pojasnimo z manjšim številom glavnih komponent. Dobljene glavne komponente iz večjega števila spremenljivk smo uporabili tudi kot dodatne pojasnjevalne spremenljivke $\mathrm{v}$ regresijski analizi. Zaradi tega sta bili faktorska analiza in metoda glavnih komponent izvedeni pred regresijsko analizo.

Poleg tega smo s pomočjo statističnega programa AMOS izvedli še modeliranje z linearnimi strukturnimi enačbami, ki združuje analizo vzročnih povezav testiranih hipotez in merjenje posredno merljivih latentnih spremenljivk. Pri raziskovanju smo preučevali celo skupino medsebojnih odnosov, kar lahko izvajamo s strukturnim modeliranjem enačb (SEM). S to metodo si pomagamo, ko analiziramo več medsebojnih odnosov hkrati. Metoda ima dve glavni značilnosti: sposobnost ocenjevanja multiplih in medsebojno povezanih odvisnosti ter sposobnost vključevanja latentnih spremenljivk. Strukturno modeliranje enačb ponavadi izvajamo v dveh delih: v prvem, merskem, delu pojasnjujemo, v kolikšni meri smo z merjenimi spremenljivkami sploh pojasnili latentne spremenljivke, $\mathrm{v}$ drugem, strukturnem, delu pa pojasnjujemo, kako so latentne spremenljivke medsebojno povezane. 


\section{Opisne statistike vzorca anketirancev v turističnih agencijah in njihovih poslovalnicah}

$\mathrm{V}$ tem sklopu sta predstavljeni analiza in interpretacija podatkov, pridobljenih iz izpolnjenih spletnih anketnih vprašalnikov in anketnih vprašalnikov, prejetih po klasični pošti.

Vprašanja $\mathrm{v}$ anketnem vprašalniku se nanašajo na naslednje sklope:

- sociodemografske značilnosti anketirancev;

- značilnosti turističnih agencij in njihovih poslovalnic;

- človeški kapital;

- organizacijsko klimo;

- rast;

- donosnost;

- dobičkonosnost TA.

Sociodemografske značilnosti anketirancev

Preglednica 2: Spol

\begin{tabular}{lccc} 
Funkcija zaposlitve & Spol & Frekvenca & Delež $(\%)$ \\
\hline \multirow{2}{*}{ Lastnik/manager/vodja } & Ženski & 52 & 46,4 \\
& Moški & 60 & 53,6 \\
\cline { 2 - 4 } & Skupaj & I12 & 100,0 \\
\hline \multirow{2}{*}{ Drugi zaposleni } & Ženski & 126 & 56,0 \\
& Moški & 99 & 44,0 \\
\cline { 2 - 4 } & Skupaj & 225 & 100,0 \\
\hline
\end{tabular}


Preglednica 2 prikazuje, da je v anketi med lastniki/managerji/vodji (v nadaljevanju $1 / \mathrm{m} / \mathrm{v}$ ) in drugimi zaposlenimi ( $v$ nadaljevanju $\mathrm{d} / \mathrm{z}$ ), ne glede na funkcijo zaposlitve, dokaj enakomerna zastopanost po spolu, saj je sodelovalo 52,8 \% žensk in 47,2 \% moških.

Preglednica 3 prikazuje, da največ $1 / \mathrm{m} / \mathrm{v}$ spada v starostni razred nad 40 do 50 let, najmanj pa v starostni razred do 30 let, kamor spada tudi najmanj $\mathrm{d} / \mathrm{z}$, največ $\mathrm{d} / \mathrm{z}$ pa spada $\mathrm{v}$ starostni razred nad 30 do 40 let.

\section{Preglednica 3: Starost}

\begin{tabular}{|c|c|c|c|}
\hline Funkcija zaposlitve & Starost & Frekvenca & Delež (\%) \\
\hline \multirow{5}{*}{ Lastnik/manager/vodja } & Do 30 let & 3 & 2,7 \\
\hline & $\mathrm{Nad}_{30}$ do 40 let & 34 & 30,1 \\
\hline & $\mathrm{Nad}_{4} 0$ do 50 let & 48 & 42,5 \\
\hline & Nad 5o let & 28 & 24,8 \\
\hline & Skupaj & 113 & 100,0 \\
\hline \multirow{5}{*}{ Drugi zaposleni } & Do 30 let & 30 & 13,3 \\
\hline & $\mathrm{Nad}_{30}$ do 40 let & $8 \mathrm{I}$ & 36,0 \\
\hline & $\mathrm{Nad}_{4} 0$ do 50 let & 78 & 34,7 \\
\hline & Nad so let & 36 & 16,0 \\
\hline & Skupaj & 225 & 100,0 \\
\hline
\end{tabular}

Kot je razvidno iz preglednice 4 , je največ $1 / \mathrm{m} / \mathrm{v}$ in $\mathrm{d} / \mathrm{z}$ z delovno dobo na področja turizma nad Io do 20 let, najmanj $1 / \mathrm{m} / \mathrm{v}$ in $\mathrm{d} / \mathrm{z}$ pa $\mathrm{z}$ delovno dobo na področju turizma nad 30 let.

Preglednica 4: Število let zaposlitve na področju turizma

\begin{tabular}{|c|c|c|c|}
\hline Funkcija zaposlitve & $\begin{array}{c}\text { Stevilo let zaposlitve na } \\
\text { področju turizma }\end{array}$ & Frekvenca & $\operatorname{Delež~}(\%)$ \\
\hline \multirow{5}{*}{ Lastnik/manager/vodja } & Do io let & $\mathrm{I} 3$ & 11,5 \\
\hline & Nad io do 20 let & 49 & 43,4 \\
\hline & $\mathrm{Nad}_{20}$ do 30 let & 47 & 41,6 \\
\hline & $\mathrm{Nad}_{30}$ let & 4 & 3,5 \\
\hline & Skupaj & $\mathrm{II} 3$ & 100,0 \\
\hline \multirow{5}{*}{ Drugi zaposleni } & Do iolet & 77 & 34,2 \\
\hline & Nad io do 20 let & 78 & 34,7 \\
\hline & Nad 20 do 30 let & 67 & 29,8 \\
\hline & $\mathrm{Nad}_{30}$ let & 3 & 1,3 \\
\hline & Skupaj & 225 & 100,0 \\
\hline
\end{tabular}


Preglednica 5 prikazuje, da je največ $1 / \mathrm{m} / \mathrm{v}$ zaposlenih $\mathrm{v}$ trenutni turistični agenciji/poslovalnici nad Io do 20 let, najmanj pa nad 30 let, kakor tudi d/z; med d/z jih je največ zaposlenih $\mathrm{v}$ trenutni turistični agenciji/poslovalnici do ro let.

Preglednica 5: Število let zaposlitve v trenutni turistični agenciji/poslovalnici

\begin{tabular}{|c|c|c|c|}
\hline Funkcija zaposlitve & $\begin{array}{l}\text { Število let zaposlitve v } \\
\text { trenutni TA/poslovalnici }\end{array}$ & Frekvenca & Delež (\%) \\
\hline \multirow{5}{*}{ Lastnik/manager/vodja } & Do io let & 40 & 35,4 \\
\hline & Nad Io do 20 let & 45 & 39,8 \\
\hline & Nad 20 do 30 let & 27 & 23,9 \\
\hline & $\mathrm{Nad}_{30}$ let & I & 0,9 \\
\hline & Skupaj & $\mathrm{II} 3$ & 100,0 \\
\hline \multirow{5}{*}{ Drugi zaposleni } & Do io let & IO5 & 46,7 \\
\hline & Nad Io do 20 let & $9 \mathrm{I}$ & 40,4 \\
\hline & $\mathrm{Nad}_{20}$ do 30 let & 27 & 12,0 \\
\hline & Nad 30 let & 2 & 0,9 \\
\hline & Skupaj & 225 & 100,0 \\
\hline
\end{tabular}

Kot je razvidno iz preglednice 6 , ima med $1 / \mathrm{m} / \mathrm{v}$ in $\mathrm{d} / \mathrm{z}$ največ anketirancev visokošolsko ali univerzitetno izobrazbo, najmanj $1 / \mathrm{m} / \mathrm{v}$ pa ima podiplomsko izobrazbo (magisterij, doktorat); nihče od $1 / \mathrm{m} / \mathrm{v}$ nima poklicne izobrazbe, med d/z pa jih ima najmanj poklicno izobrazbo.

Preglednica 6: Zaključena stopnja izobrazbe

\begin{tabular}{|c|c|c|c|}
\hline Funkcija zaposlitve & Zaključena stopnja izobrazbe & Frekvenca & $\operatorname{Delež~}(\%)$ \\
\hline \multirow{6}{*}{ Lastnik/manager/vodja } & Poklicna & $\circ$ & $\circ$ \\
\hline & Srednješolska & 22 & 19,5 \\
\hline & Višješolska & $3 \mathrm{I}$ & 27,4 \\
\hline & Visokošolska ali univerzitetna & 53 & 46,9 \\
\hline & Podiplomska (magisterij, doktorat) & 7 & 6,2 \\
\hline & Skupaj & $\mathrm{II} 3$ & 100,0 \\
\hline \multirow{6}{*}{ Drugi zaposleni } & Poklicna & 3 & $\mathrm{I}, 3$ \\
\hline & Srednješolska & 48 & 21,3 \\
\hline & Višješolska & 72 & 32,0 \\
\hline & Visokošolska ali univerzitetna & 9I & 40,4 \\
\hline & Podiplomska (magisterij, doktorat) & II & 4,9 \\
\hline & Skupaj & 225 & 100,0 \\
\hline
\end{tabular}


Iz preglednice 7 je razvidno, da ima med $\mathrm{l} / \mathrm{m} / \mathrm{v}$ in $\mathrm{d} / \mathrm{z}$ večina sklenjeno pogodbo za nedoločen čas s polnim delovnim časom, najmanj pa jih ima pogodbo za določen čas s polnim delovnim časom; med $\mathrm{d} / \mathrm{z}$ pa jih ima najmanj pogodbo za nedoločen čas $s$ krajšim delovnim časom. Tisti $\mathrm{l} / \mathrm{m} / \mathrm{v}$ in $\mathrm{d} / \mathrm{z}$, ki so navedli drugo vrsto zaposlitve, niso napisali posebej, za kakšno vrsto zaposlitve gre.

Preglednica 7: Vrsta zaposlitve

\begin{tabular}{|c|c|c|c|}
\hline Funkcija zaposlitve & Vrsta zaposlitve & Frekvenca & Delež $(\%)$ \\
\hline \multirow{5}{*}{ Lastnik/manager/vodja } & Nedoločen čas s krajšim delovnim časom & 5 & 4,4 \\
\hline & Nedoločen čas s polnim delovnim časom & 95 & $84, \mathrm{I}$ \\
\hline & Določen čas s polnim delovnim časom & 2 & I,8 \\
\hline & Drugo (ustrezno navedite) & II & 9,7 \\
\hline & Skupaj & $\mathrm{II} 3$ & 100,0 \\
\hline \multirow{6}{*}{ Drugi zaposleni } & Nedoločen čas s krajšim delovnim časom & 7 & 3,1 \\
\hline & Nedoločen čas s polnim delovnim časom & 167 & 74,2 \\
\hline & Določen čas s krajšim delovnim časom & 13 & 5,8 \\
\hline & Določen čas s polnim delovnim časom & 17 & 7,6 \\
\hline & Drugo (ustrezno navedite) & 21 & 9,3 \\
\hline & Skupaj & 225 & 100,0 \\
\hline
\end{tabular}

Iz preglednice 8 , kjer je bilo možnih več odgovorov, je tako razvidno, da je največ njihovega dela na področju prodaje turističnih aranžmajev in na področju organizacije turističnih aranžmajev, najmanj jih je navedlo drugo delo in niso napisali posebej, za kakšno delo gre, malo pa je tudi zaposlenih na področju računovodstva.

Preglednica 8: Funkcija zaposlitve

\begin{tabular}{lcc} 
Funkcija zaposlitve & Frekvenca & Delež $(\%)$ \\
\hline Lastnik/manager/vodja & III & 18,6 \\
Organizator turističnih aranžmajev & 163 & 27,3 \\
Prodajalec turističnih aranžmajev & 205 & 34,4 \\
Zaposlen na področju trženja & 91 & 15,3 \\
Zaposlen na področju računovodstva & 18 & 3,0 \\
Drugo (ustrezno navedite) & 8 & 1,3 \\
\hline Skupaj & 596 & 100,0 \\
\hline
\end{tabular}




\section{Značilnosti turističnih agencij in njihovih poslovalnic}

Iz preglednice 9 je razvidno, da je največ $1 / \mathrm{m} / \mathrm{v}$ in $\mathrm{d} / \mathrm{z}$ odgovorilo, da je glede na standardno klasifikacijo dejavnosti (v nadaljevanju SKD) njihova glavna dejavnost dejavnost organizatorjev potovanj, najmanj $1 / \mathrm{m} / \mathrm{v}$ in $\mathrm{d} / \mathrm{z}$ pa je odgovorilo, da so njihova glavna dejavnost rezervacije in druge $s$ potovanji povezane dejavnosti.

Preglednica 9: Glavna dejavnost turistične agencije/ poslovalnice glede na standardno klasifikacijo dejavnosti (SKD)

\begin{tabular}{|c|c|c|c|}
\hline Funkcija zaposlitve & Glavna dejavnost glede na SKD & Frekvenca & Delež $(\%)$ \\
\hline \multirow{4}{*}{ Lastnik/manager/vodja } & 79.120 - dejavnost organizatorjev potovanj & 78 & 69,0 \\
\hline & 79.IIO - dejavnost potovalnih agencij & 32 & 28,3 \\
\hline & $\begin{array}{c}79.900 \text { - rezervacije in druge s potovanji } \\
\text { povezane dejavnosti }\end{array}$ & 3 & 2,7 \\
\hline & Skupaj & $\mathrm{II} 3$ & 100,0 \\
\hline \multirow{4}{*}{ Drugi zaposleni } & 79.120 - dejavnost organizatorjev potovanj & 154 & 69,1 \\
\hline & 79.IIO - dejavnost potovalnih agencij & 53 & 23,8 \\
\hline & $\begin{array}{c}79.900 \text { - rezervacije in druge s potovanji } \\
\text { povezane dejavnosti }\end{array}$ & 16 & 7,2 \\
\hline & Skupaj & 223 & 100,0 \\
\hline
\end{tabular}

Kot nakazuje preglednica ıo, kjer je bil možen en odgovor oz. sta bila možna odgovora dva, lahko pri l/m/v in tudi $\mathrm{d} / \mathrm{z}$ zaznamo, da imajo skoraj vse turistične agencije/poslovalnice obe licenci.

Preglednica ro: Vrsta licence za dejavnost pri Gospodarski zbornici Slovenije

\begin{tabular}{|c|c|c|c|c|}
\hline Funkcija zaposlitve & & Vrsta licence pri GZS & Frekvenca & Delež $(\%)$ \\
\hline \multirow{3}{*}{ Lastnik/manager/vodja } & \multirow{2}{*}{ Vrsta licence } & Organiziranje turističnih aranžmajev & 105 & \\
\hline & & Prodaja turističnih aranžmajev & 104 & 49,8 \\
\hline & Skupaj & & 209 & 100,0 \\
\hline \multirow{3}{*}{ Drugi zaposleni } & \multirow{2}{*}{ Vrsta licence } & Organiziranje turističnih aranžmajev & $2 \mathrm{II}$ & 50,1 \\
\hline & & Prodaja turističnih aranžmajev & 210 & 49,9 \\
\hline & Skupaj & & 421 & 100,0 \\
\hline
\end{tabular}

Preglednica i kaže, da je največ $1 / \mathrm{m} / \mathrm{v}$ in $\mathrm{d} / \mathrm{z}$ odgovorilo, da imajo glede na organizacijski status turistično agencijo, in najmanj, da imajo poslovalnico, najmanj d/z pa je navedlo drugo, pri čemer niso opredelili, za kakšen organizacijski status gre. 


\begin{tabular}{|c|c|c|c|}
\hline Funkcija zaposlitve & Organizacijski status & Frekvenca & Delež $(\%)$ \\
\hline \multirow{5}{*}{ Lastnik/manager/vodja } & $»$ Tour operator $\ll$ & 14 & 12,4 \\
\hline & Turistična agencija & 93 & 82,3 \\
\hline & Poslovalnica & 2 & I,8 \\
\hline & Drugo (ustrezno navedite) & 4 & 3,5 \\
\hline & Skupaj & $\mathrm{II} 3$ & 100,0 \\
\hline \multirow{5}{*}{ Drugi zaposleni } & $\gg$ Tour operator $\ll$ & 18 & $8, \mathrm{I}$ \\
\hline & Turistična agencija & $18 \mathrm{I}$ & $88_{1,2}$ \\
\hline & Poslovalnica & 23 & 10,3 \\
\hline & Drugo (ustrezno navedite) & I & 0,4 \\
\hline & Skupaj & 223 & 100,0 \\
\hline
\end{tabular}

Preglednica I 2 nakazuje, da je največ $\mathrm{l} / \mathrm{m} / \mathrm{v}$ in $\mathrm{d} / \mathrm{z}$ odgovorilo, da gre za status družbe z omejeno odgovornostjo (d. o. o.), najmanj pa se jih je odločilo za drugo, kjer niso posebej opredelili, za kakšen pravni status subjekta gre.

Preglednica 12: Pravni status

\begin{tabular}{|c|c|c|c|}
\hline Funkcija zaposlitve & Pravni status & Frekvenca & $\operatorname{Delež~}(\%)$ \\
\hline \multirow{6}{*}{ Lastnik/manager/vodja } & Samostojni podjetnik (s. p.) & 20 & 17,7 \\
\hline & Družba z omejeno odgovornostjo (d. o. o.) & 83 & 73,5 \\
\hline & Družba z neomejeno odgovornostjo (d. n. o.) & 2 & $\mathrm{I}, 8$ \\
\hline & Delniška družba (d. d.) & 7 & 6,2 \\
\hline & Drugo (ustrezno navedite): & I & 0,9 \\
\hline & Skupaj & II3 & 100,0 \\
\hline \multirow{5}{*}{ Drugi zaposleni } & Samostojni podjetnik (s. p.) & IO & 4,7 \\
\hline & Družba z omejeno odgovornostjo (d. o. o.) & 172 & 80,0 \\
\hline & Delniška družba (d. d.) & 32 & 14,9 \\
\hline & Drugo (ustrezno navedite): & I & 0,5 \\
\hline & Skupaj & 215 & 100,0 \\
\hline
\end{tabular}




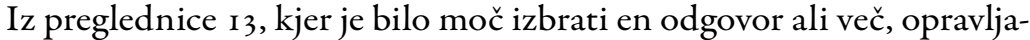
nje posameznih dejavnosti skupaj pa predstavlja Ioo \%, je razvidno, da so $\mathrm{l} / \mathrm{m} / \mathrm{v}$ in $\mathrm{d} / \mathrm{z}$ največ odgovorov namenili prodaji lastnih turističnih aranžmajev, najmanjkrat pa so se oboji odločili za drugo, kjer niso navedli, za katero dejavnost gre.

Preglednica I3: Delež (\%) preučevanih dejavnosti v turistični agenciji/poslovalnici

\begin{tabular}{|c|c|c|c|c|c|c|}
\hline $\begin{array}{l}\text { Funkcija } \\
\text { zaposlitve }\end{array}$ & $\begin{array}{l}\text { Delež }(\%) \text { preučevanih dejavnostiv turistični } \\
\text { agenciji/poslovalnici }\end{array}$ & $\mathbf{N}$ & Min. & Maks. & $\begin{array}{c}\text { Povprečna } \\
\text { vrednost }\end{array}$ & $\begin{array}{l}\text { Standardni } \\
\text { odklon }\end{array}$ \\
\hline \multirow{5}{*}{$\begin{array}{l}\text { Lastnik/ } \\
\text { manager/ } \\
\text { vodja }\end{array}$} & Prodaja lastnih turističnih aranžmajev & IIO & $\circ$ & 100 & 55,64 & 29,167 \\
\hline & Prodaja turističnih aranžmajev »tour operatorjev« & 90 & $\circ$ & 90 & 24,04 & 16,143 \\
\hline & $\begin{array}{l}\text { Prodaja turističnih aranžmajev drugih turističnih } \\
\text { agencij }\end{array}$ & 93 & $\circ$ & 85 & 18,04 & 14,580 \\
\hline & Prodaja letalskih vozovnic & 90 & $\circ$ & 90 & 14,09 & 15,083 \\
\hline & Drugo & 69 & $\circ$ & 20 & $\mathrm{I}, \mathrm{OI}$ & 3,089 \\
\hline \multirow{5}{*}{$\begin{array}{l}\text { Drugi } \\
\text { zaposleni }\end{array}$} & Prodaja lastnih turističnih aranžmajev & 205 & 10 & 100 & 47,76 & 19,250 \\
\hline & Prodaja turističnih aranžmajev »tour operatorjev« & 190 & $\circ$ & 50 & 23,22 & 9,730 \\
\hline & $\begin{array}{c}\text { Prodaja turističnih aranžmajev drugih turističnih } \\
\text { agencij }\end{array}$ & 190 & $\circ$ & 40 & 16,91 & 7,704 \\
\hline & Prodaja letalskih vozovnic & 197 & $\circ$ & 60 & 14,50 & 10,720 \\
\hline & Drugo & 16I & $\circ$ & 100 & 2,02 & 9,407 \\
\hline
\end{tabular}

Iz preglednice $\mathrm{I} 4$ je razvidno, da so $\mathrm{l} / \mathrm{m} / \mathrm{v}$ in $\mathrm{d} / \mathrm{z}$ največkrat odgovorili, da imajo do pet zaposlenih, $1 / \mathrm{m} / \mathrm{v}$ so odgovorili, da ni TA, ki bi zaposlovala več kot 250 zaposlenih, d/z pa so odgovorili, da je najmanj TA z več kot 250 zaposlenimi. Podatki nakazujejo, da je zelo velika razlika med odgovori anketirancev glede na funkcijo zaposlitve, in sicer je največja razlika pri kategoriji do 5 zaposlenih, kjer je po odgovorih $1 / \mathrm{m} / \mathrm{v}$ za dobrih 38 odstotnih točk več zaposlenih glede na odgovore $\mathrm{d} / \mathrm{z}$. Ravno tako pa je tudi velika razlika pri kategoriji od 6 do 9 zaposlenih, kjer so d/z odgovorili, da je za dobrih $\mathrm{I} 3$ odstotnih točk več zaposlenih glede na odgovore $1 / \mathrm{m} / \mathrm{v}$.

Preglednica is na temo pokritosti trga glede na opravljanje dejavnosti nakazuje, da gre, ne glede na funkcijo zaposlitve, za dokaj enake odgovore, in sicer gre najpogosteje za pokritost na domačem in tujem trgu, najmanj pa za pokritost samo na tujem trgu. 
Preglednica I 4: Število zaposlenih v turistični agenciji/poslovalnici

\begin{tabular}{|c|c|c|c|}
\hline Funkcija zaposlitve & Število zaposlenih v TA & Frekvenca & Delež $(\%)$ \\
\hline \multirow{8}{*}{ Lastnik/manager/vodja } & Dos & 76 & 67,9 \\
\hline & Od 6 do 9 & 12 & 10,7 \\
\hline & Od 10 do 29 & 7 & 6,3 \\
\hline & Od 30 do 49 & 8 & 7,1 \\
\hline & Od 50 do 99 & 7 & 6,3 \\
\hline & Od 100 do 249 & 2 & I,8 \\
\hline & $\mathrm{Nad} 250$ & $\circ$ & $\circ$ \\
\hline & Skupaj & II2 & 100,0 \\
\hline \multirow{8}{*}{ Drugi zaposleni } & Dos & 62 & 29,5 \\
\hline & Od 6 do 9 & 50 & 23,8 \\
\hline & Od 10 do 29 & 35 & 16,7 \\
\hline & $\mathrm{Od}_{30}$ do 49 & 20 & 9,5 \\
\hline & Od 50 do 99 & 32 & 15,2 \\
\hline & Od 100 do 249 & IO & 4,8 \\
\hline & $\mathrm{Nad} 250$ & I & 0,5 \\
\hline & Skupaj & 210 & 100,0 \\
\hline
\end{tabular}

Preglednica I s: Pokritost trga (domači, tuji) glede na opravljanje dejavnosti

\begin{tabular}{lccc} 
Funkcija zaposlitve & Pokritost trga & Frekvenca & Delež $(\%)$ \\
\hline Lastnik/manager/vodja & Domači trg & 26 & 23,2 \\
& Tuji trg & 12 & 10,7 \\
& Domači in tuji trg & 74 & $66, \mathrm{I}$ \\
\cline { 2 - 4 } & Skupaj & II2 & 100,0 \\
\hline Domači trg & 27 & 12,9 \\
\hline Tuji trg & 9 & 4,3 \\
\hline & Domači in tuji trg & 174 & 82,9 \\
\hline & Skupaj & 210 & 100,0 \\
\hline
\end{tabular}

Iz preglednica 16 je razvidno, da gre, ne glede na funkcijo zaposlitve, za dokaj enake odgovore, in sicer da se v največji meri ukvarjajo z emitiv- 
nim in receptivnim turizmom, najmanj pa z drugo dejavnostjo, kjer niso navedli, za katero dejavnost gre.

Preglednica I6: Dejavnost (emitivni turizem, receptivni turizem) glede na državljanstvo gostov (izletnikov, turistov, obiskovalcev)

\begin{tabular}{|c|c|c|c|}
\hline Funkcija zaposlitve & Dejavnost glede na državljanstvo gostov & Frekvenca & Delež $(\%)$ \\
\hline \multirow{5}{*}{ Lastnik/manager/vodja } & $\begin{array}{l}\text { Emitivni turizem (odhod domačih gostov } \\
\text { v tujino) }\end{array}$ & 40 & 35,7 \\
\hline & $\begin{array}{l}\text { Receptivni turizem (prihod tujih gostov } \\
\text { v Slovenijo) }\end{array}$ & 10 & 8,9 \\
\hline & Emitivni in receptivni turizem & 6I & 54,5 \\
\hline & Drugo & I & 0,9 \\
\hline & Skupaj & 112 & $\mathrm{IOO}, \mathrm{O}$ \\
\hline \multirow{5}{*}{ Drugi zaposleni } & $\begin{array}{l}\text { Emitivni turizem (odhod domačih gostov } \\
\qquad \mathrm{v} \text { tujino) }\end{array}$ & 52 & 24,9 \\
\hline & $\begin{array}{l}\text { Receptivni turizem (prihod tujih gostov } \\
\text { v Slovenijo) }\end{array}$ & 7 & 3,3 \\
\hline & Emitivni in receptivni turizem & 149 & $7 \mathrm{I}, 3$ \\
\hline & Drugo & I & 0,5 \\
\hline & Skupaj & 209 & 100,0 \\
\hline
\end{tabular}

\section{Človeški kapital}

Pri vprašanjih, navedenih v preglednicah od 17 do vključno 35, so anketiranci lahko ocenili stopnjo svojega strinjanja z zapisanimi trditvami s posameznega področja tako, da so ob vsaki trditvi obkrožili (izbrali) eno številko na 5-stopenjski lestvici ( 1 - sploh se ne strinjam, 2 - ne strinjam se, 3 - se niti ne strinjam niti strinjam, 4 - strinjam se, 5 - popolnoma se strinjam).

Preglednica $17 \mathrm{kaže}$, da so $1 / \mathrm{m} / \mathrm{v}$ in tudi $\mathrm{d} / \mathrm{z}$ najvišjo oceno namenili dejavniku Uporabljamo internet. Najnižjo oceno so $1 / \mathrm{m} / \mathrm{v}$ namenili dejavniku Sodelujemo z zunanjimi raziskovalnimi institucijami, d/z pa dejavniku Spremljamo strokovno literaturo.

Preglednica I $8 \mathrm{kaže}$, da so $1 / \mathrm{m} / \mathrm{v}$ najvišjo oceno namenili dejavnikoma Shranjujemo zapise (imamo arhiv) o svojem nastanku, razvoju in viziji delovanja ter Shranjujemo znanje (imamo arhiv) o izvedbi in vsebini delovnih procesov; najnižjo oceno pa so namenili dejavniku Imamo dobro organizirano dokumentacijo o znanju in dosežkih zaposlenih. Anketiranci iz skupine $d / z$ pa so najvišjo oceno namenili dejavniku Podpiramo 


\section{objavo uspehov, najnižjo pa dejavniku Shranjujemo zapise (imamo arhiv) o svojem nastanku, razvoju in viziji delovanja.}

\section{Preglednica 17: Pridobivanje znanja}

\begin{tabular}{|c|c|c|c|c|}
\hline Pridobivanje znanja & Funkcija zaposlitve & $\mathbf{N}$ & $\begin{array}{c}\text { Povprečna } \\
\text { vrednost }(I-5)\end{array}$ & $\begin{array}{l}\text { Standardni } \\
\text { odklon }\end{array}$ \\
\hline \multirow{3}{*}{ Uporabljamo internet. } & Lastnik/manager/vodja & 105 & 4,72 & 0,509 \\
\hline & Drugi zaposleni & 208 & 4,52 & 0,688 \\
\hline & Skupaj & 313 & 4,62 & 0,599 \\
\hline \multirow{3}{*}{ Spremljamo strokovno literaturo. } & Lastnik/manager/vodja & 104 & 3,84 & I,OI6 \\
\hline & Drugi zaposleni & 208 & 3,65 & $\mathrm{I}, \mathrm{137}$ \\
\hline & Skupaj & 312 & 3,75 & 1,077 \\
\hline \multirow{3}{*}{$\begin{array}{l}\text { Turistična agencija spodbuja } \\
\text { zaposlene pri nadaljnjem } \\
\text { izobraževanju. }\end{array}$} & Lastnik/manager/vodja & 103 & 4,24 & 0,734 \\
\hline & Drugi zaposleni & 208 & 4,06 & 0,877 \\
\hline & Skupaj & 311 & 4,15 & 0,806 \\
\hline \multirow{3}{*}{$\begin{array}{l}\text { Dijakom/študentom omogočamo } \\
\text { opravljanje prakse, seminarskih nalog } \\
\text { ali diplomskih nalog na primeru naše } \\
\text { turistične agencije. }\end{array}$} & Lastnik/manager/vodja & 104 & 3,98 & I,, 088 \\
\hline & Drugi zaposleni & 208 & 4,07 & 0,862 \\
\hline & Skupaj & 312 & 4,03 & 0,975 \\
\hline \multirow{3}{*}{ Izvajamo interna usposabljanja. } & Lastnik/manager/vodja & 104 & 4,03 & 1,178 \\
\hline & Drugi zaposleni & 208 & 4,24 & 0,798 \\
\hline & Skupaj & 312 & 4,14 & 0,988 \\
\hline \multirow{3}{*}{ Sodelujemo z zunanjimi sodelavci. } & Lastnik/manager/vodja & 104 & 4,30 & 0,902 \\
\hline & Drugi zaposleni & 207 & 4,31 & 0,778 \\
\hline & Skupaj & 311 & $4,3 \mathrm{I}$ & 0,840 \\
\hline \multirow{3}{*}{$\begin{array}{l}\text { Spodbujamo sodelovanje z drugimi } \\
\text { podjetji pri raznih delih. }\end{array}$} & Lastnik/manager/vodja & 104 & 4,27 & $0,8 \circ 3$ \\
\hline & Drugi zaposleni & 208 & 4,26 & 0,834 \\
\hline & Skupaj & 312 & 4,27 & ०,819 \\
\hline \multirow{3}{*}{$\begin{array}{l}\text { Izven TA se udeležujemo različnih } \\
\text { seminarjev, delavnic in tudi } \\
\text { turističnih sejmov. }\end{array}$} & Lastnik/manager/vodja & 103 & 4,33 & 0,833 \\
\hline & Drugi zaposleni & 208 & 4,38 & 0,745 \\
\hline & Skupaj & 311 & 4,36 & 0,789 \\
\hline \multirow{3}{*}{$\begin{array}{l}\text { Sodelujemo z zunanjimi } \\
\text { raziskovalnimi institucijami. }\end{array}$} & Lastnik/manager/vodja & 104 & 3,42 & $\mathrm{I}, 473$ \\
\hline & Drugi zaposleni & 208 & $4, \mathrm{II}$ & 1,076 \\
\hline & Skupaj & 312 & 3,77 & 1,275 \\
\hline
\end{tabular}




\begin{tabular}{|c|c|c|c|c|}
\hline Shranjevanje znanja & Funkcija zaposlitve & $\mathbf{N}$ & $\begin{array}{c}\text { Povprečna } \\
\text { vrednost }(1-5)\end{array}$ & $\begin{array}{l}\text { Standardni } \\
\text { odklon }\end{array}$ \\
\hline \multirow{3}{*}{$\begin{array}{l}\text { Shranjujemo zapise (imamo arhiv) } \\
\text { o svojem nastanku, razvoju in viziji } \\
\text { delovanja. }\end{array}$} & Lastnik/manager/vodja & 105 & 4,10 & 0,904 \\
\hline & Drugi zaposleni & 203 & 4,10 & 0,839 \\
\hline & Skupaj & 308 & 4,10 & 0,872 \\
\hline \multirow{3}{*}{$\begin{array}{l}\text { Shranjujemo znanje (imamo arhiv) o } \\
\text { izvedbi in vsebini delovnih procesov. }\end{array}$} & Lastnik/manager/vodja & 105 & 4,10 & 0,898 \\
\hline & Drugi zaposleni & 203 & $4,2 \mathrm{I}$ & 0,717 \\
\hline & Skupaj & 308 & 4,16 & $0,8 \circ 8$ \\
\hline \multirow{3}{*}{$\begin{array}{l}\text { Imamo dobro organizirano } \\
\text { dokumentacijo o znanju in dosežkih } \\
\text { zaposlenih. }\end{array}$} & Lastnik/manager/vodja & 105 & 4, OI & 1,070 \\
\hline & Drugi zaposleni & 203 & 4,22 & 0,904 \\
\hline & Skupaj & 308 & 4,12 & 0,987 \\
\hline \multirow{3}{*}{ Podpiramo objavo uspehov. } & Lastnik/manager/vodja & 105 & 4,02 & 1,074 \\
\hline & Drugi zaposleni & 203 & 4,23 & 0,965 \\
\hline & Skupaj & 308 & 4,13 & 1,020 \\
\hline
\end{tabular}

Preglednica 19 kaže, da so $1 / \mathrm{m} / \mathrm{v}$ najvišjo oceno namenili dejavniku Dobro počutje $v$ turistični agenciji pozitivno vpliva na prenos znanja, najnižjo oceno, kot tudi d/z, pa so namenili dejavniku Zaposleni skrivamo svoje znanje pred sodelavci, ker menimo, da s tem povečujemo svojo konkurenčno prednost pred njimi, d/z pa so najvišjo oceno namenili dejavniku Vsak zaposleni je usposobljen za opravljanje več delovnih nalog.

Preglednica i 9: Prenos znanja

\begin{tabular}{|c|c|c|c|c|}
\hline Prenos znanja & Funkcija zaposlitve & $\mathbf{N}$ & $\begin{array}{c}\text { Povprečna } \\
\text { vrednost }(\mathbf{I}-5)\end{array}$ & $\begin{array}{l}\text { Standardni } \\
\text { odklon }\end{array}$ \\
\hline \multirow{3}{*}{$\begin{array}{l}\text { Dobro počutje v turistični agenciji } \\
\text { pozitivno vpliva na prenos znanja. }\end{array}$} & Lastnik/manager/vodja & 100 & 4,60 & 0,532 \\
\hline & Drugi zaposleni & 202 & 4,39 & 0,698 \\
\hline & Skupaj & 302 & 4,50 & 0,615 \\
\hline \multirow{3}{*}{$\begin{array}{l}\text { Vsak zaposleni je usposobljen za } \\
\text { opravljanje več delovnih nalog. }\end{array}$} & Lastnik/manager/vodja & 100 & 4,38 & 0,693 \\
\hline & Drugi zaposleni & 202 & 4,40 & 0,664 \\
\hline & Skupaj & 302 & 4,39 & 0,679 \\
\hline \multirow{3}{*}{$\begin{array}{l}\text { Vpeljano imamo timsko } \\
\text { in projektno delo. }\end{array}$} & Lastnik/manager/vodja & 100 & 4,24 & 0,793 \\
\hline & Drugi zaposleni & 202 & 4,19 & 0,906 \\
\hline & Skupaj & 302 & 4,22 & 0,850 \\
\hline
\end{tabular}


Na voljo imamo prostore, kjer se lahko zadržujemo in neformalno družimo.

Imamo učinkovit sistem svetovanja in mentoriranja mlajših in novih sodelavcev širjenje.

Pripravljeni smo posredovati svoje

Lastnik/manager/vodja

3,94

Drugi zaposlen

\begin{tabular}{cccc} 
Drugi zaposleni & 202 & 3,90 & 1,043 \\
\hline Skupaj & 302 & 3,92 & 1,089 \\
\hline
\end{tabular}

Lastnik/manager/vodja Ioo $\quad 3,98 \quad 0,84 \mathrm{I}$

$\begin{array}{lll}\text { Drugi zaposleni } \quad 201 \quad 3,90 & 0,970\end{array}$

\begin{tabular}{cccc} 
Skupaj & 301 & 3,94 & 0,906 \\
\hline Lastnik/manager/vodja & I00 & 4,17 & 0,995
\end{tabular}

\begin{tabular}{cccc} 
Drugi zaposleni & 202 & 4,08 & 0,872 \\
\hline Skupaj & 302 & 4,13 & 0,934
\end{tabular}
znanje, vendar imamo za to premalo časa.

$\begin{array}{lll}\text { Lastnik/manager/vodja } \quad \text { IOO } \quad \text { 4,II } & 0,909\end{array}$

\begin{tabular}{cccc} 
Drugi zaposleni & 202 & 4,03 & 0,897 \\
\hline Skupaj & 302 & 4,07 & 0,903 \\
\hline Lastnik/manager/vodja & 99 & 3,95 & 0,896
\end{tabular}

Svoje zaposlene spodbujamo k objavljanju svojih dosežkov.

\begin{tabular}{cccc} 
Drugi zaposleni & 20I & 3,92 & I,03I \\
\hline Skupaj & 300 & 3,94 & 0,964
\end{tabular}

Imamo učinkovit računalniško podprt sistem za dostop in iskanje po lastnih zbirkah znanja.

$\begin{array}{llll}\text { Lastnik/manager/vodja } \quad 100 \quad 3,87 & \text { I,060 }\end{array}$

$\begin{array}{lll}\text { Drugi zaposleni } \quad 201 & 3,99 & 0,97\end{array}$

\begin{tabular}{|c|c|c|c|c|}
\hline zbirkah znanja. & Skupaj & 301 & 3,93 & 1,016 \\
\hline \multirow{3}{*}{$\begin{array}{l}\text { Organiziramo različne interne } \\
\text { izobraževalne delavnice, s katerimi } \\
\text { spodbujamo izmenjavo mnenj. }\end{array}$} & Lastnik/manager/vodja & 99 & 3,73 & $\mathrm{I}, \mathrm{IOS}$ \\
\hline & Drugi zaposleni & 202 & $3,9 \mathrm{I}$ & $\mathrm{I}, \mathrm{OOI}$ \\
\hline & Skupaj & 301 & 3,82 & 1,053 \\
\hline \multirow{3}{*}{$\begin{array}{l}\text { Zaposleni imamo premalo komuni- } \\
\text { kacijskih spretnosti, potrebnih } \\
\text { za prenos znanja. }\end{array}$} & Lastnik/manager/vodja & 99 & 3,56 & 1,272 \\
\hline & Drugi zaposleni & $20 \mathrm{I}$ & 3,73 & I,086 \\
\hline & Skupaj & 300 & 3,65 & 1,179 \\
\hline \multirow{3}{*}{$\begin{array}{l}\text { Organizirane imamo predstavitve in } \\
\text { razprave o dosežkih zaposlenih. }\end{array}$} & Lastnik/manager/vodja & 99 & 3,53 & 1,232 \\
\hline & Drugi zaposleni & $2 \mathrm{OI}$ & 3,73 & 1,067 \\
\hline & Skupaj & 300 & 3,63 & $\mathrm{I}, \mathrm{I} 5 \mathrm{O}$ \\
\hline \multirow{3}{*}{$\begin{array}{l}\text { Turistična agencija ne stimulira dovolj } \\
\text { pretoka znanja med zaposlenimi. }\end{array}$} & Lastnik/manager/vodja & 99 & 3,55 & 1,327 \\
\hline & Drugi zaposleni & 202 & 3,83 & 0,978 \\
\hline & Skupaj & 301 & 3,69 & 1,153 \\
\hline \multirow{3}{*}{$\begin{array}{l}\text { Zaposleni skrivamo svoje znanje pred } \\
\text { sodelavci, ker menimo, da s tem poveču- } \\
\text { jemo svojo konkurenčno prednost pred } \\
\text { njimi. }\end{array}$} & Lastnik/manager/vodja & 99 & 3,23 & 1,564 \\
\hline & Drugi zaposleni & 202 & 3,64 & I, 239 \\
\hline & Skupaj & 301 & 3,44 & $\mathrm{I}, 402$ \\
\hline
\end{tabular}


Preglednica 20 kaže, da so $1 / \mathrm{m} / \mathrm{v}$ najvišjo oceno namenili dejavniku Uspešno uporabljamo svoje znanje v delovnih procesih, najnižjo oceno pa dejavniku Znanja med zaposlenimi je dovolj, problematična je le njegova uporaba, $\mathrm{d} / \mathrm{z}$ pa so najvišjo oceno namenili dejavniku Uspešno uporabljamo lastne izkušnje za razreševanje novih izzivov, najnižjo oceno pa dejavniku Najboljše predloge nagradimo.

Preglednica 20: Uporaba znanja

\begin{tabular}{|c|c|c|c|c|}
\hline Uporaba znanja & Funkcija zaposlitve & $\mathbf{N}$ & $\begin{array}{c}\text { Povprečna } \\
\text { vrednost }(\mathbf{I}-5)\end{array}$ & $\begin{array}{l}\text { Standardni } \\
\text { odklon }\end{array}$ \\
\hline \multirow{3}{*}{ Koristne predloge uporabimo v praksi. } & Lastnik/manager/vodja & 95 & 4,32 & 0,623 \\
\hline & Drugi zaposleni & 199 & 4,09 & 0,860 \\
\hline & Skupaj & 294 & 4,21 & 0,742 \\
\hline \multirow{3}{*}{$\begin{array}{l}\text { Uspešno uporabljamo lastne izkušnje za } \\
\text { razreševanje novih izzivov. }\end{array}$} & Lastnik/manager/vodja & 95 & 4,38 & 0,702 \\
\hline & Drugi zaposleni & 199 & 4,24 & 0,666 \\
\hline & Skupaj & 294 & 4,31 & 0,684 \\
\hline \multirow{3}{*}{$\begin{array}{l}\text { Uspešno uporabljamo svoje znanje } \\
\text { v delovnih procesih. }\end{array}$} & Lastnik/manager/vodja & 95 & 4,42 & 0,693 \\
\hline & Drugi zaposleni & 195 & $4,2 \mathrm{I}$ & 0,759 \\
\hline & Skupaj & 290 & 4,32 & 0,726 \\
\hline \multirow{3}{*}{$\begin{array}{l}\text { Zaposlene spodbujamo, da novo znanje } \\
\text { uporabijo v praksi. }\end{array}$} & Lastnik/manager/vodja & 95 & 4,40 & 0,706 \\
\hline & Drugi zaposleni & 199 & 4,17 & 0,779 \\
\hline & Skupaj & 294 & 4,29 & 0,743 \\
\hline \multirow{3}{*}{ Najboljše predloge nagradimo. } & Lastnik/manager/vodja & 94 & $4, \mathrm{I} 4$ & 0,850 \\
\hline & Drugi zaposleni & 199 & 3,90 & 1,038 \\
\hline & Skupaj & 293 & 4,02 & 0,944 \\
\hline \multirow{3}{*}{$\begin{array}{l}\text { Turistična agencija uspešno izkoristi } \\
\text { potenciale svojih zaposlenih. }\end{array}$} & Lastnik/manager/vodja & 94 & $4,2 \mathrm{I}$ & 0,731 \\
\hline & Drugi zaposleni & 197 & $4, \mathrm{OI}$ & 1,023 \\
\hline & Skupaj & 291 & $4, \mathrm{II}$ & 0,877 \\
\hline \multirow{3}{*}{$\begin{array}{l}\text { Posameznike nagradimo glede na uspešno } \\
\text { uporabljeno novo znanje - finančne } \\
\text { spodbude. }\end{array}$} & Lastnik/manager/vodja & 94 & 4,02 & 0,904 \\
\hline & Drugi zaposleni & 198 & 3,98 & 1,054 \\
\hline & Skupaj & 292 & 4,00 & 0,979 \\
\hline \multirow{3}{*}{ Pogovarjamo se o svojih potrebah po znanju. } & Lastnik/manager/vodja & 94 & 4,17 & 0,757 \\
\hline & Drugi zaposleni & 198 & 4,07 & 0,982 \\
\hline & Skupaj & 292 & 4,12 & 0,870 \\
\hline \multirow{3}{*}{$\begin{array}{l}\text { Posameznike nagradimo glede na uspeš- } \\
\text { no uporabljeno novo znanje - nefinančne } \\
\text { spodbude. }\end{array}$} & Lastnik/manager/vodja & 94 & 4,24 & 0,785 \\
\hline & Drugi zaposleni & 197 & $4, \mathrm{OI}$ & $\mathrm{I}, 033$ \\
\hline & Skupaj & 291 & 4,13 & 0,909 \\
\hline \multirow{3}{*}{$\begin{array}{l}\text { Znanja med zaposlenimi je dovolj, } \\
\text { problematična je le njegova uporaba. }\end{array}$} & Lastnik/manager/vodja & 94 & 3,80 & 1,169 \\
\hline & Drugi zaposleni & 198 & 4,02 & 0,969 \\
\hline & Skupaj & 292 & 3,91 & 1,069 \\
\hline
\end{tabular}




\section{Preglednica $2 \mathrm{r}$ kaže, da so $\mathrm{l} / \mathrm{m} / \mathrm{v}$ in tudi $\mathrm{d} / \mathrm{z}$ najvišjo oceno namenili}

dejavniku Informacije iščemo na internetu, najnižjo oceno pa so oboji namenili dejavniku Izobražujemo se na področju računovodstva.

Preglednica 21: Vrsta (način) izobraževanja

\begin{tabular}{|c|c|c|c|c|}
\hline Vrsta (način) izobraževanja & Funkcija zaposlitve & $\mathbf{N}$ & $\begin{array}{c}\text { Povprečna } \\
\text { vrednost }(\mathbf{I}-5)\end{array}$ & $\begin{array}{l}\text { Standardni } \\
\text { odklon }\end{array}$ \\
\hline \multirow{3}{*}{$\begin{array}{l}\text { Uveden imamo interni akt o učeči se } \\
\text { organizaciji. }\end{array}$} & Lastnik/manager/vodja & 9I & 3,53 & 1,328 \\
\hline & Drugi zaposleni & 195 & 3,75 & 1,136 \\
\hline & Skupaj & 286 & 3,64 & 1,232 \\
\hline \multirow{3}{*}{$\begin{array}{l}\text { Izobraževanje poteka predvsem } \\
\text { znotraj (interno) turistične agencije. }\end{array}$} & Lastnik/manager/vodja & 92 & 4,04 & 0,937 \\
\hline & Drugi zaposleni & 195 & 4,03 & 0,846 \\
\hline & Skupaj & 287 & 4,04 & 0,892 \\
\hline \multirow{3}{*}{$\begin{array}{l}\text { Izobraževanje poteka predvsem zunaj } \\
\text { (eksterno) turistične agencije. }\end{array}$} & Lastnik/manager/vodja & 92 & 3,62 & $\mathrm{I}, \mathrm{I} 47$ \\
\hline & Drugi zaposleni & 195 & $3,8 \mathrm{I}$ & 1,047 \\
\hline & Skupaj & 287 & 3,72 & 1,097 \\
\hline \multirow{3}{*}{$\begin{array}{l}\text { Imamo sestanke s profesionalnimi } \\
\text { svetovalci. }\end{array}$} & Lastnik/manager/vodja & 92 & 3,75 & 1,315 \\
\hline & Drugi zaposleni & 195 & 3,73 & 1,127 \\
\hline & Skupaj & 287 & 3,74 & $\mathrm{I}, 22 \mathrm{I}$ \\
\hline \multirow{3}{*}{ Prebiramo strokovno literaturo. } & Lastnik/manager/vodja & 92 & 4,23 & 0,915 \\
\hline & Drugi zaposleni & 195 & 3,75 & 1,140 \\
\hline & Skupaj & 287 & 3,99 & $\mathrm{I}, \mathrm{O} 28$ \\
\hline \multirow{3}{*}{ Informacije iščemo na internetu. } & Lastnik/manager/vodja & 92 & 4,45 & 0,618 \\
\hline & Drugi zaposleni & 195 & 4,10 & 0,743 \\
\hline & Skupaj & 287 & 4,28 & $0,68 \mathrm{I}$ \\
\hline \multirow{3}{*}{$\begin{array}{l}\text { Obiskujemo sejme, razstave, } \\
\text { konference. }\end{array}$} & Lastnik/manager/vodja & 92 & 4,21 & 0,859 \\
\hline & Drugi zaposleni & 195 & 3,93 & 0,944 \\
\hline & Skupaj & 287 & 4,07 & 0,902 \\
\hline \multirow{3}{*}{$\begin{array}{l}\text { Izmenjujemo mnenja z drugimi } \\
\text { turističnimi agencijami. }\end{array}$} & Lastnik/manager/vodja & 92 & 4,17 & 0,765 \\
\hline & Drugi zaposleni & 195 & 3,88 & 0,977 \\
\hline & Skupaj & 287 & 4,03 & 0,871 \\
\hline \multirow{3}{*}{$\begin{array}{l}\text { Udeležujemo se študijskih izletov/ } \\
\text { potovanj. }\end{array}$} & Lastnik/manager/vodja & 92 & 4,07 & 0,912 \\
\hline & Drugi zaposleni & 195 & 4,00 & 1,025 \\
\hline & Skupaj & 287 & 4,04 & 0,969 \\
\hline \multirow{3}{*}{ Izobražujemo se na področju trženja. } & Lastnik/manager/vodja & 92 & 3,85 & 1,089 \\
\hline & Drugi zaposleni & 195 & 3,54 & 1,313 \\
\hline & Skupaj & 287 & 3,70 & $\mathrm{I}, 20 \mathrm{I}$ \\
\hline \multirow{3}{*}{$\begin{array}{l}\text { Izobražujemo se na področju } \\
\text { računovodstva. }\end{array}$} & Lastnik/manager/vodja & 92 & 3,47 & 1,338 \\
\hline & Drugi zaposleni & 195 & 3,19 & $\mathrm{I}, 493$ \\
\hline & Skupaj & 287 & 3,33 & 1,416 \\
\hline
\end{tabular}




\begin{tabular}{|c|c|c|c|c|}
\hline Vrsta (način) izobraževanja & Funkcija zaposlitve & $\mathbf{N}$ & $\begin{array}{c}\text { Povprečna } \\
\text { vrednost }(\mathbf{I}-5)\end{array}$ & $\begin{array}{l}\text { Standardni } \\
\text { odklon }\end{array}$ \\
\hline \multirow{3}{*}{$\begin{array}{l}\text { Izobražujemo se na področjih } \\
\text { geografije, zgodovine in umetnostne } \\
\text { zgodovine. }\end{array}$} & Lastnik/manager/vodja & 92 & 3,68 & 1,257 \\
\hline & Drugi zaposleni & 195 & 3,46 & 1,370 \\
\hline & Skupaj & 287 & 3,57 & 1,314 \\
\hline \multirow{3}{*}{$\begin{array}{l}\text { Izobražujemo se na področju } \\
\text { tujih jezikov. }\end{array}$} & Lastnik/manager/vodja & 92 & 3,84 & $\mathrm{I}, \mathrm{I22}$ \\
\hline & Drugi zaposleni & 195 & 3,54 & $\mathrm{I}, 28 \mathrm{I}$ \\
\hline & Skupaj & 287 & 3,69 & 1,202 \\
\hline \multirow{3}{*}{ Izobražujemo se na področju vodenja. } & Lastnik/manager/vodja & 92 & 3,86 & 0,990 \\
\hline & Drugi zaposleni & 195 & 3,69 & 1,205 \\
\hline & Skupaj & 287 & 3,78 & 1,098 \\
\hline \multirow{3}{*}{$\begin{array}{l}\text { Izobražujemo se na področju } \\
\text { komunikacije. }\end{array}$} & Lastnik/manager/vodja & 92 & 3,85 & 0,925 \\
\hline & Drugi zaposleni & 195 & 3,89 & 1,052 \\
\hline & Skupaj & 287 & 3,87 & 0,989 \\
\hline \multirow{3}{*}{$\begin{array}{l}\text { Izobražujemo se na področjih odnosov } \\
\text { med zaposlenimi in odnosov do strank. }\end{array}$} & Lastnik/manager/vodja & 92 & 3,85 & 1,005 \\
\hline & Drugi zaposleni & 195 & 3,97 & 1,052 \\
\hline & Skupaj & 287 & 3,91 & 1,029 \\
\hline
\end{tabular}

Preglednica 22 kaže, da so $1 / \mathrm{m} / \mathrm{v}$ in tudi $\mathrm{d} / \mathrm{z}$ najvišjo oceno namenili dejavniku Udeležujemo se enodnevnih oblik izobraževanj (tečaji, seminarji), najnižjo oceno so $1 / \mathrm{m} / \mathrm{v}$ namenili dejavniku Eksterno izobraževanje poteka znotraj delovnega časa, $\mathrm{d} / \mathrm{z}$ pa dejavniku Interno izobraževanje poteka znotraj delovnega časa.

Preglednica 22: Čas izobraževanja

\begin{tabular}{|c|c|c|c|c|}
\hline Čas izobraževanja & Funkcija zaposlitve & $\mathbf{N}$ & $\begin{array}{c}\text { Povprečna } \\
\text { vrednost }(\mathbf{I}-5)\end{array}$ & $\begin{array}{l}\text { Standardni } \\
\text { odklon }\end{array}$ \\
\hline \multirow{3}{*}{$\begin{array}{l}\text { Interno izobraževanje poteka znotraj } \\
\text { delovnega časa. }\end{array}$} & Lastnik/manager/vodja & 90 & 4,18 & 0,815 \\
\hline & Drugi zaposleni & 193 & 4,05 & 1,059 \\
\hline & Skupaj & 283 & 4,12 & 0,937 \\
\hline \multirow{3}{*}{$\begin{array}{l}\text { Eksterno izobraževanje poteka znotraj } \\
\text { delovnega časa. }\end{array}$} & Lastnik/manager/vodja & 90 & 4,09 & 1,046 \\
\hline & Drugi zaposleni & 192 & 4,19 & 1,026 \\
\hline & Skupaj & 282 & 4,14 & 1,036 \\
\hline \multirow{3}{*}{$\begin{array}{l}\text { Udeležujemo se večdnevnih izobraževanj } \\
\text { (tečaji, seminarji). }\end{array}$} & Lastnik/manager/vodja & 89 & 4,16 & 0,952 \\
\hline & Drugi zaposleni & 193 & 4,24 & 0,982 \\
\hline & Skupaj & 282 & 4,20 & 0,967 \\
\hline \multirow{3}{*}{$\begin{array}{l}\text { Udeležujemo se enodnevnih oblik } \\
\text { izobraževanj (tečaji, seminarji). }\end{array}$} & Lastnik/manager/vodja & 89 & 4,37 & 0,774 \\
\hline & Drugi zaposleni & 193 & 4,38 & 0,735 \\
\hline & Skupaj & 282 & 4,38 & 0,755 \\
\hline
\end{tabular}




\section{Organizacijska klima}

Preglednica $23 \mathrm{kaže,} \mathrm{da} \mathrm{so} \mathrm{l} / \mathrm{m} / \mathrm{v}$ in tudi $\mathrm{d} / \mathrm{z}$ najvišjo oceno namenili dejavniku Čutimo se odgovorne za kakovost svojega dela, najnižjo oceno pa so oboji namenili dejavniku Druge sodelavce in oddelke (trženje, računovodstvo) obravnavamo kot svoje spoštovane stranke.

Preglednica 23: Odnos do kakovosti

\begin{tabular}{|c|c|c|c|c|}
\hline Odnos do kakovosti & Funkcija zaposlitve & $\mathbf{N}$ & $\begin{array}{c}\text { Povprečna } \\
\text { vrednost }(\mathbf{I}-5)\end{array}$ & $\begin{array}{l}\text { Standardni } \\
\text { odklon }\end{array}$ \\
\hline \multirow{3}{*}{$\begin{array}{l}\text { Čutimo se odgovorne za kakovost } \\
\text { svojega dela. }\end{array}$} & Lastnik/manager/vodja & 90 & $4,7 \mathrm{I}$ & 0,456 \\
\hline & Drugi zaposleni & 193 & 4,67 & 0,514 \\
\hline & Skupaj & 283 & 4,69 & 0,485 \\
\hline \multirow{3}{*}{$\begin{array}{l}\text { Prispevamo k doseganju standarda } \\
\text { kakovosti. }\end{array}$} & Lastnik/manager/vodja & 90 & 4,60 & 0,536 \\
\hline & Drugi zaposleni & 192 & 4,56 & 0,584 \\
\hline & Skupaj & 282 & 4,58 & 0,560 \\
\hline \multirow{3}{*}{$\begin{array}{l}\text { Druge sodelavce in oddelke (trženje, } \\
\text { računovodstvo) obravnavamo kot } \\
\text { svoje spoštovane stranke. }\end{array}$} & Lastnik/manager/vodja & 90 & 4,49 & 0,623 \\
\hline & Drugi zaposleni & 193 & 4,42 & 0,650 \\
\hline & Skupaj & 283 & 4,46 & 0,637 \\
\hline \multirow{3}{*}{ Standard in cilj kakovosti sta jasna. } & Lastnik/manager/vodja & 90 & 4,53 & 0,706 \\
\hline & Drugi zaposleni & 192 & 4,44 & 0,707 \\
\hline & Skupaj & 282 & 4,49 & 0,707 \\
\hline
\end{tabular}

Preglednica $24 \mathrm{kaže}$, da so $1 / \mathrm{m} / \mathrm{v}$ in $\mathrm{d} / \mathrm{z}$ najvišjo oceno namenili dejavniku Zavedamo se, da so izboljšave nujne, najnižjo oceno pa so oboji namenili dejavniku Delovne metode stalno izboljšujemo in posodabljamo.

Preglednica $25 \mathrm{kaže}$, da so $1 / \mathrm{m} / \mathrm{v}$ najvišjo oceno namenili dejavniku Učimo se drug od drugega, najnižjo oceno pa dejavniku Sistem našega usposabljanja je dober; $\mathrm{d} / \mathrm{z}$ so najvišjo oceno namenili dejavniku Usposobljeni smo za svoje delo, najnižjo oceno pa dejavniku Sistem našega usposabljanja je dober. 
Opisne statistike vzorca anketirancevv turističnih agencijah in njihovih poslovalnicah

Preglednica 24: Inovativnost (izboljšave, dvig kakovosti, nižji stroški poslovanja) in iniciativnost (aktivno iskanje priložnosti za lasten prispevek rezultatom)

\begin{tabular}{|c|c|c|c|c|}
\hline Inovativnost in iniciativnost & Funkcija zaposlitve & $\mathbf{N}$ & $\begin{array}{c}\text { Povprečna } \\
\text { vrednost }(\mathbf{I}-5)\end{array}$ & $\begin{array}{l}\text { Standardni } \\
\text { odklon }\end{array}$ \\
\hline \multirow{3}{*}{ Izboljšave predlagamo vsi - ne le vodstvo. } & Lastnik/manager/vodja & 90 & 4,54 & 0,690 \\
\hline & Drugi zaposleni & 193 & 4,44 & 0,713 \\
\hline & Skupaj & 283 & 4,49 & 0,702 \\
\hline \multirow{3}{*}{$\begin{array}{l}\text { Delovne metode stalno izboljšujemo in } \\
\text { posodabljamo. }\end{array}$} & Lastnik/manager/vodja & 90 & 4,48 & 0,640 \\
\hline & Drugi zaposleni & 193 & 4,37 & 0,739 \\
\hline & Skupaj & 283 & 4,43 & 0,690 \\
\hline \multirow{3}{*}{ Zavedamo se, da so izboljšave nujne. } & Lastnik/manager/vodja & 90 & 4,68 & 0,493 \\
\hline & Drugi zaposleni & 193 & 4,47 & 0,677 \\
\hline & Skupaj & 283 & 4,58 & 0,585 \\
\hline \multirow{3}{*}{$\begin{array}{l}\text { Pripravljeni smo prevzeti tveganje za } \\
\text { uveljavitev svojih zamisli. }\end{array}$} & Lastnik/manager/vodja & 90 & 4,49 & 0,674 \\
\hline & Drugi zaposleni & 193 & 4,42 & 0,761 \\
\hline & Skupaj & 283 & 4,46 & 0,718 \\
\hline
\end{tabular}

Preglednica 25: Strokovna usposobljenost in učenje

\begin{tabular}{|c|c|c|c|c|}
\hline Strokovna usposobljenost in učenje & Funkcija zaposlitve & $\mathbf{N}$ & $\begin{array}{c}\text { Povprečna } \\
\text { vrednost }(1-5)\end{array}$ & $\begin{array}{l}\text { Standardni } \\
\text { odklon }\end{array}$ \\
\hline \multirow{3}{*}{ Učimo se drug od drugega. } & Lastnik/manager/vodja & 89 & 4,43 & 0,672 \\
\hline & Drugi zaposleni & 193 & 4,26 & $0,8 \circ 2$ \\
\hline & Skupaj & 282 & 4,35 & 0,737 \\
\hline \multirow{3}{*}{ Usposobljeni smo za svoje delo. } & Lastnik/manager/vodja & 89 & 4,33 & 0,670 \\
\hline & Drugi zaposleni & I9I & 4,38 & 0,653 \\
\hline & Skupaj & 280 & 4,36 & 0,662 \\
\hline \multirow{3}{*}{$\begin{array}{l}\text { Pri usposabljanju se upoštevajo } \\
\text { naše želje. }\end{array}$} & Lastnik/manager/vodja & 89 & 4,35 & 0,659 \\
\hline & Drugi zaposleni & 192 & 4,22 & 0,769 \\
\hline & Skupaj & $28 \mathrm{I}$ & 4,29 & 0,714 \\
\hline \multirow{3}{*}{$\begin{array}{l}\text { Omogočeno nam je potrebno } \\
\text { usposabljanje za dobro delo. }\end{array}$} & Lastnik/manager/vodja & 89 & 4,34 & 0,768 \\
\hline & Drugi zaposleni & 193 & 4,27 & $0,8 \mathrm{I} \circ$ \\
\hline & Skupaj & 282 & 4,31 & 0,789 \\
\hline \multirow{3}{*}{ Sistem našega usposabljanja je dober. } & Lastnik/manager/vodja & 89 & 4,24 & 0,866 \\
\hline & Drugi zaposleni & 193 & 4,19 & 0,901 \\
\hline & Skupaj & 282 & 4,22 & 0,884 \\
\hline
\end{tabular}


Preglednica 26 kaže, da so $1 / \mathrm{m} / \mathrm{v}$ in d/z najvišjo oceno namenili dejavniku Pripravljeni smo na dodaten napor, kadar je to potrebno, najnižjo oceno pa oboji namenili dejavniku Dober delovni rezultat se hitro opazi in se pohvali.

Preglednica 26: Motivacija in zavzetost

\begin{tabular}{|c|c|c|c|c|}
\hline Motivacija in zavzetost & Funkcija zaposlitve & $\mathbf{N}$ & $\begin{array}{c}\text { Povprečna } \\
\text { vrednost }(I-5)\end{array}$ & $\begin{array}{c}\text { Standardni } \\
\text { odklon }\end{array}$ \\
\hline \multirow{3}{*}{ Zavzeti smo za svoje delo. } & Lastnik/manager/vodja & 89 & 4,60 & 0,538 \\
\hline & Drugi zaposleni & 193 & 4,54 & 0,603 \\
\hline & Skupaj & 282 & 4,57 & 0,571 \\
\hline \multirow{3}{*}{$\begin{array}{l}\text { Pripravljeni smo na dodaten napor, } \\
\text { kadar je to potrebno. }\end{array}$} & Lastnik/manager/vodja & 89 & 4,64 & 0,549 \\
\hline & Drugi zaposleni & 193 & 4,56 & 0,627 \\
\hline & Skupaj & 282 & 4,60 & 0,588 \\
\hline \multirow{3}{*}{$\begin{array}{l}\text { Imamo postavljene zelo visoke } \\
\text { zahteve za delovno uspešnost. }\end{array}$} & Lastnik/manager/vodja & 89 & 4,49 & 0,659 \\
\hline & Drugi zaposleni & 193 & 4,44 & 0,712 \\
\hline & Skupaj & 282 & 4,47 & 0,686 \\
\hline \multirow{3}{*}{$\begin{array}{l}\text { Dober delovni rezultat se hitro } \\
\text { opazi in se pohvali. }\end{array}$} & Lastnik/manager/vodja & 89 & 4,44 & 0,706 \\
\hline & Drugi zaposleni & 193 & 4,30 & 0,897 \\
\hline & Skupaj & 282 & 4,37 & $0,8 \circ 2$ \\
\hline
\end{tabular}

Preglednica 27 kaže, da so $1 / \mathrm{m} / \mathrm{v}$ in d/z najvišjo oceno namenili dejavniku Sodelavci se med sabo pogovarjamo sproščeno, prijateljsko in enakopravno, najnižjo oceno pa so oboji namenili dejavniku Delovni sestanki so redni.

Preglednica 28 kaže, da so $1 / \mathrm{m} / \mathrm{v}$ najvišjo oceno namenili dejavniku Pri svojem delu smo samostojni, najnižjo oceno pa dvema dejavnikoma, in sicer dejavniku Nimamo ukazovalnega vodenja in dejavniku Vodstvo se $\mathrm{z}$ nami pogovarja o delovnih rezultatih; $\mathrm{d} / \mathrm{z}$ so najvišjo oceno namenili dejavniku Pri svojem delu smo samostojni, najnižjo oceno pa kot l/m/v dejavniku Nimamo ukazovalnega vodenja. 
Opisne statistike vzorca anketirancevv turističnih agencijah in njihovih poslovalnicah

Preglednica 27: Notranja komunikacija in informiranje

\begin{tabular}{|c|c|c|c|c|}
\hline $\begin{array}{c}\text { Notranja komunikacija in informi- } \\
\text { ranje }\end{array}$ & Funkcija zaposlitve & $\mathbf{N}$ & $\begin{array}{c}\text { Povprečna } \\
\text { vrednost }(I-5)\end{array}$ & $\begin{array}{l}\text { Standardni } \\
\text { odklon }\end{array}$ \\
\hline \multirow{3}{*}{ Delovni sestanki so redni. } & Lastnik/manager/vodja & 89 & 4,16 & 0,903 \\
\hline & Drugi zaposleni & 193 & 4,10 & 0,887 \\
\hline & Skupaj & 282 & 4,13 & 0,895 \\
\hline \multirow{3}{*}{$\begin{array}{l}\text { Sodelavci se med sabo pogovarjamo } \\
\text { sproščeno, prijateljsko in enakopravno. }\end{array}$} & Lastnik/manager/vodja & 88 & 4,49 & 0,567 \\
\hline & Drugi zaposleni & 193 & $4,3 \mathrm{I}$ & 0,753 \\
\hline & Skupaj & $28 \mathrm{I}$ & 4,40 & 0,660 \\
\hline \multirow{3}{*}{$\begin{array}{l}\text { O poslovnih zadevah smo obveščeni } \\
\text { na razumljiv način. }\end{array}$} & Lastnik/manager/vodja & 89 & 4,44 & 0,639 \\
\hline & Drugi zaposleni & 192 & 4,27 & 0,837 \\
\hline & Skupaj & $28 \mathrm{I}$ & 4,36 & 0,738 \\
\hline \multirow{3}{*}{$\begin{array}{l}\text { Vodstvo nam posreduje dovolj infor- } \\
\text { macij, da lahko delo dobro opravljamo. }\end{array}$} & Lastnik/manager/vodja & 89 & 4,38 & 0,699 \\
\hline & Drugi zaposleni & 193 & 4,29 & 0,877 \\
\hline & Skupaj & 282 & 4,34 & 0,788 \\
\hline
\end{tabular}

Preglednica 28: Vodenje (delegiranje) dela

\begin{tabular}{|c|c|c|c|c|}
\hline Vodenje (delegiranje) dela & Funkcija zaposlitve & $\mathbf{N}$ & $\begin{array}{c}\text { Povprečna } \\
\text { vrednost }(\mathrm{I}-5)\end{array}$ & $\begin{array}{l}\text { Standardni } \\
\text { odklon }\end{array}$ \\
\hline \multirow{3}{*}{ Pri svojem delu smo samostojni. } & Lastnik/manager/vodja & 89 & 4,56 & 0,656 \\
\hline & Drugi zaposleni & 193 & 4,49 & 0,605 \\
\hline & Skupaj & 282 & 4,53 & 0,631 \\
\hline \multirow{3}{*}{$\begin{array}{l}\text { Vodstvo nas spodbuja k sprejemanju } \\
\text { večje odgovornosti za svoje delo. }\end{array}$} & Lastnik/manager/vodja & 89 & 4,44 & 0,706 \\
\hline & Drugi zaposleni & 192 & $4,4 \mathrm{I}$ & $0,68 \mathrm{I}$ \\
\hline & Skupaj & $28 \mathrm{I}$ & 4,43 & 0,694 \\
\hline \multirow{3}{*}{ Nimamo ukazovalnega vodenja. } & Lastnik/manager/vodja & 89 & 4,34 & 0,738 \\
\hline & Drugi zaposleni & 193 & $4,2 \mathrm{I}$ & 0,929 \\
\hline & Skupaj & 282 & 4,28 & 0,834 \\
\hline \multirow{3}{*}{$\begin{array}{l}\text { Vodstvo se z nami pogovarja } \\
\text { o delovnih rezultatih. }\end{array}$} & Lastnik/manager/vodja & 89 & 4,34 & 0,673 \\
\hline & Drugi zaposleni & 193 & 4,35 & 0,743 \\
\hline & Skupaj & 282 & 4,35 & 0,708 \\
\hline \multirow{3}{*}{$\begin{array}{l}\text { Vodstvo od nas sprejema utemeljene } \\
\text { pripombe glede vodenja. }\end{array}$} & Lastnik/manager/vodja & 89 & 4,36 & 0,711 \\
\hline & Drugi zaposleni & 193 & 4,27 & 0,890 \\
\hline & Skupaj & 282 & 4,32 & $0,8 \circ \mathrm{I}$ \\
\hline
\end{tabular}


Preglednica 29 kaže, da so $1 / \mathrm{m} / \mathrm{v}$ najvišjo oceno namenili dejavniku Med sabo si zaupamo, najnižjo oceno pa dejavniku Odnosi med sodelavci so dobri; $d$ /z so najvišjo oceno namenili dejavniku Odnosi med sodelavci so dobri, najnižjo oceno pa dejavniku Med sabo mnogo bolj sodelujemo kot tekmujemo.

\section{Preglednica 29: Notranji odnosi}

\begin{tabular}{|c|c|c|c|c|}
\hline Notranji odnosi & Funkcija zaposlitve & $\mathbf{N}$ & $\begin{array}{c}\text { Povprečna } \\
\text { vrednost }(I-5)\end{array}$ & $\begin{array}{l}\text { Standardni } \\
\text { odklon }\end{array}$ \\
\hline \multirow{3}{*}{ Cenimo delo svojih sodelavcev. } & Lastnik/manager/vodja & 88 & 4,47 & 0,606 \\
\hline & Drugi zaposleni & 193 & 4,32 & 0,684 \\
\hline & Skupaj & $28 \mathrm{I}$ & 4,40 & 0,645 \\
\hline \multirow{3}{*}{$\begin{array}{l}\text { Med sabo mnogo bolj sodelujemo } \\
\text { kot tekmujemo. }\end{array}$} & Lastnik/manager/vodja & 87 & 4,48 & 0,626 \\
\hline & Drugi zaposleni & 193 & 4,27 & 0,743 \\
\hline & Skupaj & 280 & 4,38 & 0,685 \\
\hline \multirow{3}{*}{ Odnosi med sodelavci so dobri. } & Lastnik/manager/vodja & 88 & $4,4 \mathrm{I}$ & 0,600 \\
\hline & Drugi zaposleni & 193 & 4,36 & 0,758 \\
\hline & Skupaj & $28 \mathrm{I}$ & 4,39 & 0,679 \\
\hline \multirow{3}{*}{ Konflikte rešujemo v skupno korist. } & Lastnik/manager/vodja & 88 & 4,43 & 0,563 \\
\hline & Drugi zaposleni & 193 & 4,31 & 0,840 \\
\hline & Skupaj & $28 \mathrm{I}$ & 4,37 & 0,702 \\
\hline \multirow{3}{*}{ Med sabo si zaupamo. } & Lastnik/manager/vodja & 88 & 4,56 & 0,604 \\
\hline & Drugi zaposleni & 193 & 4,31 & 0,905 \\
\hline & Skupaj & $28 \mathrm{I}$ & 4,44 & 0,755 \\
\hline
\end{tabular}

Preglednica 30 kaže, da so $1 / \mathrm{m} / \mathrm{v}$ in $\mathrm{d} / \mathrm{z}$ najvišjo oceno namenili dejavniku Cilje turistične agencije sprejemamo za svoje; $1 / \mathrm{m} / \mathrm{v}$ so najnižjo oceno namenili dejavniku Pri postavljanju ciljev poleg vodstva sodelujejo tudi drugi sodelavci, $\mathrm{d} / \mathrm{z}$ pa dvema dejavnikoma, in sicer dejavniku Vodstvo sprejema odločitve pravočasno in Pri nas so pristojnosti in odgovornosti med sabo uravnotežene na vseh ravneh. 
Preglednica 30: Poznavanje poslanstva, vizije, ciljev

\begin{tabular}{|c|c|c|c|c|}
\hline Poznavanje poslanstva, vizije, ciljev & Funkcija zaposlitve & $\mathbf{N}$ & $\begin{array}{c}\text { Povprečna } \\
\text { vrednost }(1-5)\end{array}$ & $\begin{array}{l}\text { Standardni } \\
\text { odklon }\end{array}$ \\
\hline \multirow{3}{*}{$\begin{array}{l}\text { Imamo jasno oblikovano poslanstvo } \\
\text { (svoj dolgoročni razlog obstoja in } \\
\text { delovanja). }\end{array}$} & Lastnik/manager/vodja & 88 & 4,43 & 0,755 \\
\hline & Drugi zaposleni & 193 & 4,34 & $0,8 \circ 7$ \\
\hline & Skupaj & $28 \mathrm{I}$ & 4,39 & $0,78 \mathrm{I}$ \\
\hline \multirow{3}{*}{$\begin{array}{l}\text { Cilje turistične agencije sprejemamo } \\
\text { za svoje. }\end{array}$} & Lastnik/manager/vodja & 88 & 4,48 & 0,625 \\
\hline & Drugi zaposleni & 193 & 4,37 & 0,674 \\
\hline & Skupaj & $28 \mathrm{I}$ & 4,43 & 0,650 \\
\hline \multirow{3}{*}{$\begin{array}{l}\text { Cilji, ki jih s sodelavci moramo } \\
\text { doseči, so realni. }\end{array}$} & Lastnik/manager/vodja & 88 & 4,36 & 0,698 \\
\hline & Drugi zaposleni & 193 & 4,23 & 0,770 \\
\hline & Skupaj & $28 \mathrm{I}$ & 4,30 & 0,734 \\
\hline \multirow{3}{*}{$\begin{array}{l}\text { Pri postavljanju ciljev poleg vodstva } \\
\text { sodelujejo tudi drugi sodelavci. }\end{array}$} & Lastnik/manager/vodja & 88 & 4,27 & 0,723 \\
\hline & Drugi zaposleni & 193 & $4, \mathrm{II}$ & 0,892 \\
\hline & Skupaj & $28 \mathrm{I}$ & 4,19 & $0,8 \circ 8$ \\
\hline \multirow{3}{*}{$\begin{array}{l}\text { Politika in cilji so jasni vsem } \\
\text { zaposlenim. }\end{array}$} & Lastnik/manager/vodja & 88 & 4,33 & 0,784 \\
\hline & Drugi zaposleni & 193 & 4,21 & 0,859 \\
\hline & Skupaj & $28 \mathrm{I}$ & 4,27 & 0,822 \\
\hline \multirow{3}{*}{$\begin{array}{l}\text { Imamo jasno predstavo o tem, } \\
\text { kaj se od nas pričakuje pri delu. }\end{array}$} & Lastnik/manager/vodja & 87 & 4,36 & 0,570 \\
\hline & Drugi zaposleni & 193 & 4,21 & $0,8 \mathrm{II}$ \\
\hline & Skupaj & 280 & 4,29 & 0,691 \\
\hline \multirow{3}{*}{$\begin{array}{l}\text { Razumemo svoj položaj } \\
\text { v organizacijski shemi. }\end{array}$} & Lastnik/manager/vodja & 87 & 4,38 & 0,615 \\
\hline & Drugi zaposleni & 193 & 4,29 & 0,714 \\
\hline & Skupaj & 280 & 4,34 & 0,665 \\
\hline \multirow{3}{*}{ Zadolžitve so jasno opredeljene. } & Lastnik/manager/vodja & 87 & 4,44 & 0,677 \\
\hline & Drugi zaposleni & 193 & 4,25 & 0,772 \\
\hline & Skupaj & 280 & 4,35 & 0,725 \\
\hline \multirow{3}{*}{$\begin{array}{l}\text { Vodstvo sprejema odločitve } \\
\text { pravočasno. }\end{array}$} & Lastnik/manager/vodja & 87 & 4,32 & 0,883 \\
\hline & Drugi zaposleni & 193 & 4,10 & 0,946 \\
\hline & Skupaj & 280 & $4,2 \mathrm{I}$ & 0,915 \\
\hline \multirow{3}{*}{$\begin{array}{l}\text { Pri nas so pristojnosti in odgovornosti } \\
\text { med sabo uravnotežene na vseh } \\
\text { ravneh. }\end{array}$} & Lastnik/manager/vodja & 87 & 4,39 & 0,812 \\
\hline & Drugi zaposleni & 192 & 4,10 & $\mathrm{I}, \mathrm{O} 3 \mathrm{I}$ \\
\hline & Skupaj & 279 & 4,25 & 0,922 \\
\hline
\end{tabular}


Preglednica 3 I kaže, da so $1 / \mathrm{m} / \mathrm{v}$ najvišjo oceno namenili dejavniku Zadolžitve so jasno opredeljene, najnižjo oceno, kot tudi d/z, dejavniku Vodstvo odločitve sprejema pravočasno, drugo najnižnjo oceno pa so $\mathrm{d} / \mathrm{z}$ namenili še dejavniku Pri nas so pristojnosti in odgovornosti med sabo uravnotežene na vseh ravneh. Najvišjo oceno so $\mathrm{d} / \mathrm{z}$ namenili dejavniku Razumemo svoj položaj v organizacijski shemi.

Preglednica 31: Organiziranost dela

\begin{tabular}{|c|c|c|c|c|}
\hline Organiziranost dela & Funkcija zaposlitve & $\mathbf{N}$ & $\begin{array}{c}\text { Povprečna } \\
\text { vrednost }(I-5)\end{array}$ & $\begin{array}{l}\text { Standardni } \\
\text { odklon }\end{array}$ \\
\hline \multirow{3}{*}{$\begin{array}{l}\text { Imamo jasno predstavo o tem, kaj se } \\
\text { od nas pri delu pričakuje. }\end{array}$} & Lastnik/manager/vodja & 87 & 4,36 & 0,570 \\
\hline & Drugi zaposleni & 193 & $4,2 \mathrm{I}$ & o,8II \\
\hline & Skupaj & 280 & 4,29 & 0,691 \\
\hline \multirow{3}{*}{$\begin{array}{l}\text { Razumemo svoj položaj v } \\
\text { organizacijski shemi. }\end{array}$} & Lastnik/manager/vodja & 87 & 4,38 & 0,615 \\
\hline & Drugi zaposleni & 193 & 4,29 & 0,714 \\
\hline & Skupaj & 280 & 4,34 & 0,665 \\
\hline \multirow{3}{*}{ Zadolžitve so jasno opredeljene. } & Lastnik/manager/vodja & 87 & 4,44 & 0,677 \\
\hline & Drugi zaposleni & 193 & 4,25 & 0,772 \\
\hline & Skupaj & 280 & 4,35 & 0,725 \\
\hline \multirow{3}{*}{$\begin{array}{l}\text { Vodstvo odločitve sprejema } \\
\text { pravočasno. }\end{array}$} & Lastnik/manager/vodja & 87 & 4,32 & 0,883 \\
\hline & Drugi zaposleni & 193 & $4, \mathrm{IO}$ & 0,946 \\
\hline & Skupaj & 280 & $4,2 \mathrm{I}$ & 0,915 \\
\hline \multirow{3}{*}{$\begin{array}{l}\text { Pri nas so pristojnosti in odgovornosti } \\
\text { med sabo uravnotežene na vseh ravneh. }\end{array}$} & Lastnik/manager/vodja & 87 & 4,39 & 0,812 \\
\hline & Drugi zaposleni & 192 & $4, \mathrm{IO}$ & $\mathrm{I}, \mathrm{O} 3 \mathrm{I}$ \\
\hline & Skupaj & 279 & 4,25 & 0,922 \\
\hline
\end{tabular}

Preglednica $32 \mathrm{kaže}$, da so $1 / \mathrm{m} / \mathrm{v}$ in tudi $\mathrm{d} / \mathrm{z}$ najvišjo oceno namenili dejavniku Zunaj turistične agencije pozitivno govorimo o njej, najnižjo oceno pa so oboji namenili dejavniku Zaposlitev je varna oz. zagotovljena.

Preglednica 33 kaže, da so $1 / \mathrm{m} / \mathrm{v}$ in d/z najvišjo oceno namenili dejavniku Zadovoljni smo s sedanjim osebnim razvojem; $1 / \mathrm{m} / \mathrm{v}$ so najnižjo oceno namenili dejavniku Vodilni vzgajajo svoje naslednike, $\mathrm{d} / \mathrm{z}$ pa dejavniku Vsi imamo realne možnosti za napredovanje. 
Preglednica 32: Pripadnost organizaciji

\begin{tabular}{|c|c|c|c|c|}
\hline Pripadnost organizaciji & Funkcija zaposlitve & $\mathbf{N}$ & $\begin{array}{c}\text { Povprečna } \\
\text { vrednost }(\mathbf{I}-5)\end{array}$ & $\begin{array}{l}\text { Standardni } \\
\text { odklon }\end{array}$ \\
\hline \multirow{3}{*}{$\begin{array}{l}\text { Zunaj turistične agencije pozitivno } \\
\text { govorimo o njej. }\end{array}$} & Lastnik/manager/vodja & 87 & 4,56 & 0,564 \\
\hline & Drugi zaposleni & 193 & 4,45 & 0,713 \\
\hline & Skupaj & 280 & $4,5 \mathrm{I}$ & 0,639 \\
\hline \multirow{3}{*}{$\begin{array}{l}\text { Zadovoljni smo, da smo zaposleni v tej } \\
\text { turistični agenciji. }\end{array}$} & Lastnik/manager/vodja & 87 & $4,5 \mathrm{I}$ & 0,608 \\
\hline & Drugi zaposleni & 193 & 4,35 & 0,715 \\
\hline & Skupaj & 280 & 4,43 & 0,662 \\
\hline \multirow{3}{*}{ Imamo velik ugled v okolju. } & Lastnik/manager/vodja & 87 & 4,32 & 0,723 \\
\hline & Drugi zaposleni & 193 & 4,31 & 0,755 \\
\hline & Skupaj & 280 & 4,32 & 0,739 \\
\hline \multirow{3}{*}{ Zaposlitev je varna oz. zagotovljena. } & Lastnik/manager/vodja & 87 & 4,28 & 0,817 \\
\hline & Drugi zaposleni & 193 & 4,22 & 0,858 \\
\hline & Skupaj & 280 & 4,25 & 0,838 \\
\hline
\end{tabular}

Preglednica 33: Razvoj kariere

\begin{tabular}{|c|c|c|c|c|}
\hline Razvoj kariere & Funkcija zaposlitve & $\mathbf{N}$ & $\begin{array}{c}\text { Povprečna } \\
\text { vrednost }(\mathbf{I}-5)\end{array}$ & $\begin{array}{l}\text { Standardni } \\
\text { odklon }\end{array}$ \\
\hline \multirow{3}{*}{$\begin{array}{l}\text { Vsi imamo realne možnosti za } \\
\text { napredovanje. }\end{array}$} & Lastnik/manager/vodja & 87 & 4,14 & $0,89 \mathrm{I}$ \\
\hline & Drugi zaposleni & 193 & 3,90 & 1,034 \\
\hline & Skupaj & 280 & 4,02 & 0,963 \\
\hline \multirow{3}{*}{ Merila za napredovanje so jasna vsem. } & Lastnik/manager/vodja & 87 & 4,08 & 0,892 \\
\hline & Drugi zaposleni & 193 & 3,98 & 1,046 \\
\hline & Skupaj & 280 & 4,03 & 0,969 \\
\hline \multirow{3}{*}{$\begin{array}{l}\text { Zadovoljni smo s sedanjim osebnim } \\
\text { razvojem. }\end{array}$} & Lastnik/manager/vodja & 87 & 4,21 & $0,8 \circ 9$ \\
\hline & Drugi zaposleni & 193 & 4,05 & 0,951 \\
\hline & Skupaj & 280 & 4,13 & $0,88 \circ$ \\
\hline \multirow{3}{*}{ Vodilni vzgajajo svoje naslednike. } & Lastnik/manager/vodja & 86 & 4,03 & 1,079 \\
\hline & Drugi zaposleni & 193 & 3,94 & $\mathrm{I}, \mathrm{I} 28$ \\
\hline & Skupaj & 279 & 3,99 & $\mathrm{I}, \mathrm{IO} 4$ \\
\hline
\end{tabular}

Preglednica 34 kaže, da so $1 / \mathrm{m} / \mathrm{v}$ najvišjo oceno namenili dejavniku Uspešnost (doseganje nadpovprečnih delovnih rezultatov) se praviloma vrednoti po dogovorjenih ciljih in standardih, najnižjo oceno pa dejavnikoma Slabo narejenemu delu sledi graja oz. ustrezen ukrep in Tisti, ki smo bolj obremenjeni z delom, smo tudi ustrezno stimulirani; slednjemu 
so najnižjo oceno namenili tudi $\mathrm{d} / \mathrm{z}$, najvišjo oceno pa so slednji namenili dejavniku Slabo narejenemu delu sledi graja oz. ustrezen ukrep.

\section{Preglednica 34: Nagrajevanje glede na uspešnost}

\begin{tabular}{|c|c|c|c|c|}
\hline Nagrajevanje glede na uspešnost & Funkcija zaposlitve & $\mathbf{N}$ & $\begin{array}{c}\text { Povprečna } \\
\text { vrednost }(I-5)\end{array}$ & $\begin{array}{l}\text { Standardni } \\
\text { odklon }\end{array}$ \\
\hline \multirow{3}{*}{$\begin{array}{l}\text { Uspešnost (doseganje nadpovprečnih } \\
\text { delovnih rezultatov) se praviloma vred- } \\
\text { noti po dogovorjenih ciljih in standardih. }\end{array}$} & Lastnik/manager/vodja & 87 & 4,21 & 0,823 \\
\hline & Drugi zaposleni & 191 & 4,24 & 0,954 \\
\hline & Skupaj & 278 & 4,23 & 0,889 \\
\hline \multirow{3}{*}{$\begin{array}{l}\text { Razmerja med plačami zaposlenih so } \\
\text { ustrezna. }\end{array}$} & Lastnik/manager/vodja & 87 & $4, \mathrm{II}$ & 0,868 \\
\hline & Drugi zaposleni & 192 & 4,09 & 0,991 \\
\hline & Skupaj & 279 & 4,10 & 0,930 \\
\hline \multirow{3}{*}{$\begin{array}{l}\text { Tisti, ki smo bolj obremenjeni z delom, } \\
\text { smo tudi ustrezno stimulirani. }\end{array}$} & Lastnik/manager/vodja & 86 & 4,02 & 0,84 \\
\hline & Drugi zaposleni & 193 & 4,06 & 1,071 \\
\hline & Skupaj & 279 & 4,04 & 0,956 \\
\hline \multirow{3}{*}{$\begin{array}{l}\text { Naše plače so enakovredne ravni plač } \\
\text { na trgu. }\end{array}$} & Lastnik/manager/vodja & 87 & 4,06 & 0,798 \\
\hline & Drugi zaposleni & 193 & 4,17 & 0,882 \\
\hline & Skupaj & 280 & 4,12 & 0,840 \\
\hline \multirow{3}{*}{$\begin{array}{l}\text { Slabo narejenemu delu sledi graja oz } \\
\text { ustrezen ukrep. }\end{array}$} & Lastnik/manager/vodja & 87 & 4,02 & 0,862 \\
\hline & Drugi zaposleni & 193 & 4,26 & 0,839 \\
\hline & Skupaj & 280 & $4, \mathrm{I} 4$ & $0,85 \mathrm{I}$ \\
\hline
\end{tabular}

Preglednica 35 kaže, da so $1 / \mathrm{m} / \mathrm{v}$ najvišjo oceno namenili dejavniku Zadovoljni smo z delom, najnižjo oceno pa, kot tudi d/z, dejavniku Zadovoljni smo $\mathrm{z}$ višino plače; $\mathrm{d} / \mathrm{z}$ so najvišjo oceno namenili dejavniku Zadovoljni smo s sodelavci.

Preglednica 35: Zadovoljstvo zaposlenih

\begin{tabular}{lcccc} 
Zadovoljstvo zaposlenih & Funkcija zaposlitve & $\mathbf{N}$ & $\begin{array}{c}\text { Povprečna } \\
\text { vrednost }(\mathbf{I}-5)\end{array}$ & $\begin{array}{c}\text { Standardni } \\
\text { odklon }\end{array}$ \\
\cline { 2 - 4 } Z delom. & Lastnik/manager/vodja & 86 & 4,37 & 0,652 \\
& Drugi zaposleni & 193 & 4,21 & 0,70 I \\
\cline { 2 - 5 } & Skupaj & 279 & 4,29 & 0,677 \\
\hline \multirow{2}{*}{ S sodelavci. } & Lastnik/manager/vodja & 86 & 4,36 & 0,631 \\
& Drugizaposleni & 193 & 4,25 & 0,702 \\
\cline { 2 - 5 } & Skupaj & 279 & 4,31 & 0,667 \\
\hline
\end{tabular}


Opisne statistike vzorca anketirancevv turističnih agencijah in njihovih poslovalnicah

\begin{tabular}{|c|c|c|c|c|}
\hline Zadovoljstvo zaposlenih & Funkcija zaposlitve & $\mathbf{N}$ & $\begin{array}{c}\text { Povprečna } \\
\text { vrednost }(1-5)\end{array}$ & $\begin{array}{l}\text { Standardni } \\
\text { odklon }\end{array}$ \\
\hline \multirow{3}{*}{ Z neposredno nadrejenim. } & Lastnik/manager/vodja & 86 & 4,26 & 0,829 \\
\hline & Drugi zaposleni & 193 & 4,17 & 0,727 \\
\hline & Skupaj & 279 & 4,22 & 0,778 \\
\hline \multirow{3}{*}{ S stalnostjo zaposlitve. } & Lastnik/manager/vodja & 86 & 4,34 & $0,76 \mathrm{I}$ \\
\hline & Drugi zaposleni & 193 & $4, \mathrm{IO}$ & 0,79 \\
\hline & Skupaj & 279 & 4,22 & 0,776 \\
\hline \multirow{3}{*}{ Zvodstvom. } & Lastnik/manager/vodja & 86 & 4,26 & 0,654 \\
\hline & Drugi zaposleni & 193 & 4,00 & 0,829 \\
\hline & Skupaj & 279 & 4,13 & 0,742 \\
\hline \multirow{3}{*}{ Z delovnim časom. } & Lastnik/manager/vodja & 86 & 4,22 & 0,742 \\
\hline & Drugi zaposleni & 193 & 3,87 & 0,92 \\
\hline & Skupaj & 279 & 4,05 & 0,831 \\
\hline \multirow{3}{*}{ S statusom v turistični agenciji. } & Lastnik/manager/vodja & 86 & 4,27 & 0,789 \\
\hline & Drugi zaposleni & 192 & 3,99 & 0,759 \\
\hline & Skupaj & 278 & 4,13 & 0,774 \\
\hline \multirow{3}{*}{ Z možnostmi za izobraževanje. } & Lastnik/manager/vodja & 86 & 4,20 & 0,865 \\
\hline & Drugi zaposleni & 193 & 3,74 & 0,94 \\
\hline & Skupaj & 279 & 3,97 & 0,903 \\
\hline \multirow{3}{*}{$\begin{array}{l}\text { Z možnostmi za napredovanje } \\
\text { (namestnik, vodja oddelka). }\end{array}$} & Lastnik/manager/vodja & 86 & 3,99 & $0,90 \mathrm{I}$ \\
\hline & Drugi zaposleni & 193 & 3,47 & $\mathrm{I}, 06 \mathrm{I}$ \\
\hline & Skupaj & 279 & 3,73 & $0,98 \mathrm{r}$ \\
\hline \multirow{3}{*}{ Z delovnimi pogoji (oprema, prostor). } & Lastnik/manager/vodja & 86 & 4,07 & 0,905 \\
\hline & Drugi zaposleni & 193 & 3,55 & 1,084 \\
\hline & Skupaj & 279 & $3,8 \mathrm{I}$ & 0,995 \\
\hline \multirow{3}{*}{ Z višino plače. } & Lastnik/manager/vodja & 86 & 3,65 & I,196 \\
\hline & Drugi zaposleni & 193 & 2,78 & 1,398 \\
\hline & Skupaj & 279 & 3,22 & 1,297 \\
\hline \multirow{3}{*}{ Z rednim izplačilom plače. } & Lastnik/manager/vodja & 86 & 4,29 & 0,852 \\
\hline & Drugi zaposleni & 193 & 3,94 & $\mathrm{I}, \mathrm{O} 42$ \\
\hline & Skupaj & 279 & 4,12 & 0,947 \\
\hline
\end{tabular}




\section{Uspešnost poslovanja}

Na vprašanja, navedena v preglednicah od 36 do vključno 49, so glede na navodila odgovarjali samo $1 / \mathrm{m} / \mathrm{v}$.

Preglednica 36 kaže, da jih je $37,5 \%$ odgovorilo, da so se prihodki od prodaje v drugem preučevanem obdobju ( $v$ nadaljevanju p/o) glede na prvo zmanjšali, da so se prihodki od prodaje $\mathrm{v}$ drugem $\mathrm{p} / \mathrm{o}$ glede na prvo povečali, je odgovorilo $36,4 \% \mathrm{l} / \mathrm{m} / \mathrm{v}$, najmanj $1 / \mathrm{m} / \mathrm{v}(26, \mathrm{r} \%)$ pa je odgovorilo, da so prihodki od prodaje $\mathrm{v}$ drugem $\mathrm{p} / \mathrm{o}$ glede na prvo ostali dokaj enaki.

\section{Preglednica 36: Prihodki od prodaje}

Prihodki od prodaje

Prihodki od prodaje so se v obdobju 20II-2013 glede na obdobje 2008-2010 povečali.

Prihodki od prodaje so se v obdobju 20II-2013 glede na obdobje 2008-2010 zmanjšali.

Prihodki od prodaje so v obdobju 20II-2013 glede na obdobje 2008-2010 ostali dokaj enaki.

Skupaj

\section{Frekvenca Delež $(\%)$}

32

36,4

$33 \quad 37,5$

23

26,1

88

Kot je razvidno iz preglednice 37 , so se prihodki od prodaje največ povečali in tudi največ zmanjšali nad ıo do $20 \%$, kar je odgovorilo I I, $4 \%$ $1 / \mathrm{m} / \mathrm{v}$, da pa so prihodki od prodaje ostali enaki, jih je odgovorilo $26 \%$.

Preglednica 37: Prihodki od prodaje so se povečali/zmanjšali/ostali dokaj enaki

Povečali do $5 \%$

Povečali nad 5 do $10 \%$

Povečali nad to do $20 \%$

Povečali nad 20 do $35 \%$

Povečali nad $35 \%$

Zmanjšali do $5 \%$

Zmanjšali nad 5 do $10 \%$

Zmanjšali nad ıo do $20 \%$

Zmanjšali nad 20 do $35 \%$

Zmanjšali nad $35 \%$

Ostali dokaj enaki

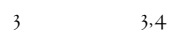

$7 \quad 8,0$

IO II, 4

$3 \quad 3,4$

$9 \quad \mathrm{IO}, 2$

$6 \quad 6,8$

$7 \quad 8,0$

IO II,4

89,1

$2 \quad 2,3$

Skupaj

23

88 
Preglednica 38 kaže, da je $42,5 \% \mathrm{l} / \mathrm{m} / \mathrm{v}$ odgovorilo, da se je dobiček v drugem p/o glede na prvo zmanjšal, najmanj (23\%) jih je odgovorilo, da je dobiček v drugem p/o glede na prvo ostal dokaj enak, 34,5\% pa je odgovorilo, da se je dobiček v drugem p/o glede na prvo povečal.

Preglednica 38: Dobiček

\begin{tabular}{lcc} 
Dobiček & Frekvenca & Delež $(\%)$ \\
\hline Dobiček se je v obdobju 2OII-20I3 glede na obdobje 2008-20IO povečal. & 30 & 34,5 \\
Dobiček se je v obdobju 20II-20I3 glede na obdobje 2008-20IO zmanjšal. & 37 & 42,5 \\
Dobiček je v obdobju 20II-20I3 glede na obdobje 2008-20IO ostal dokaj enak. & 20 & 23,0 \\
\hline Skupaj & 87 & 100,0 \\
\hline
\end{tabular}

Kot je razvidno iz preglednice 39, se je tistim l/m/v (Io,3 \%), ki se jim je dobiček povečal, ta povečal nad ıo do $20 \%$, tistim l/m/v (I 4,9\%), ki se jim je dobiček največ zmanjšal, pa se je ta zmanjšal nad $35 \%, 23 \% 1 / \mathrm{m} / \mathrm{v}$ pa je odgovorilo, da je dobiček ostal dokaj enak.

Preglednica 39: Dobiček se je povečal/zmanjšal/ostal dokaj enak

\begin{tabular}{|c|c|c|}
\hline Dobiček se je povečal/zmanjšal/ostal dokaj enak & Frekvenca & Delež $(\%)$ \\
\hline Povečal do $5 \%$ & 4 & 4,6 \\
\hline Povečal nad 5 do $10 \%$ & 8 & 9,2 \\
\hline Povečal nad ıo do $20 \%$ & 9 & 10,3 \\
\hline Povečal nad 20 do $35 \%$ & 2 & 2,3 \\
\hline Povečal nad $35 \%$ & 7 & $8, \mathrm{I}$ \\
\hline Zmanjšal do $5 \%$ & I & $\mathrm{I}, \mathrm{I}$ \\
\hline Zmanjšal nad 5 do $10 \%$ & 10 & 11,5 \\
\hline Zmanjšal nad ıo do $20 \%$ & 6 & 6,9 \\
\hline Zmanjšal nad 20 do $35 \%$ & 7 & $8, \mathrm{I}$ \\
\hline Zmanjšal nad $35 \%$ & 13 & 14,9 \\
\hline Ostal dokaj enak & 20 & 23,0 \\
\hline Skupaj & 87 & 100,0 \\
\hline
\end{tabular}

Kot je razvidno iz preglednice 40 , je največ $1 / \mathrm{m} / \mathrm{v}$ (45,3\%) odgovorilo, da je dobičkonosnost TA/poslovalnice $\mathrm{v}$ primerjavi z vsemi konkurenčnimi TA v drugem p/o glede na prvo približno enaka, najmanj ( $4,7 \%)$ pa jih je odgovorilo, da je izjemno višja. 
Nekoliko nižja

Približno enaka

Zmerno višja

$39 \quad 45,3$

Izjemno višja

$13 \quad 15,1$

Skupaj

4

$86 \quad 100,0$

Kot je razvidno iz preglednice $4 \mathrm{I}$, je največ $1 / \mathrm{m} / \mathrm{v}(48,9$ \%) odgovorilo, da je dobičkonosnost TA/poslovalnice v primerjavi s TA, ki so na trgu enako število let in v enaki fazi razvoja, v drugem p/o glede na prvo približno enaka, najmanj $(3,5 \%)$ pa jih je odgovorilo, da je izjemno višja.

Preglednica 4I: Dobičkonosnost TA/poslovalnice glede na turistične agencije, ki so na trgu enako število let in v enaki fazi razvoja ter jih poznate, v obdobju 201 I-2013 v primerjavi z obdobjem 2008-2010

\begin{tabular}{lcc}
$\begin{array}{l}\text { Dobičkonosnost TA/poslovalnice glede na turistične agencije, ki so na trgu } \\
\text { enako število let in v enaki fazi razvoja ter jih poznate, vobdobju } 2011-2013 \mathrm{~V} \text { } \\
\text { primerjavi zobdobjem 2008-2010 }\end{array}$ & Frekvenca & Delež $(\%)$ \\
Nekoliko nižja & 23 & 26,7 \\
Približno enaka & 42 & 48,9 \\
Zmerno višja & 18 & 20,9 \\
Izjemno višja & 3 & 3,5 \\
\hline Skupaj & 86 & 100,0 \\
\hline
\end{tabular}

\section{Tržni delež na domačem in tujem trgu}

Kot je razvidno iz preglednice 42 , je največ $1 / \mathrm{m} / \mathrm{v}(69,4 \%)$ odgovorilo, da je tržni delež na domačem trgu v drugem p/o glede na prvo ostal dokaj enak, $15,3 \% 1 / \mathrm{m} / \mathrm{v}$ jih je odgovorilo, da se je povečal, enak delež anketirancev pa je odgovoril, da se je zmanjšal.

Iz preglednice 43 je razvidno naslednje: kjer se je tržni delež na domačem trgu v drugem p/o glede na prvo povečal, so $1 / \mathrm{m} / \mathrm{v}(8,2 \%)$ odgovorili, da se jim je najpogosteje povečal do $5 \%$, kjer pa se je zmanjšal, so $1 / \mathrm{m} / \mathrm{v}(4,8 \%)$ odgovorili, da se jim je najpogosteje zmanjšal nad 5 do ı $\%$, enak del anketirancev pa je odgovoril, da se je najpogosteje zmanjšal nad Io do $20 \%$. 
Tržni delež na domačem trgu se je v obdobju 20II-2013 glede na obdobje 2008-20I0 povečal.

I3

13

zmanjšal

Tržni delež na domačem trgu je v obdobju 20II-20I3 glede na obdobje 2008-20I0 ostal dokaj enak.

Skupaj

Preglednica 43: Tržni delež na domačem trgu se je povečal/zmanjšal/ostal dokaj enak

\begin{tabular}{|c|c|c|}
\hline Tržni delež na domačem trgu se je povečal/zmanjšal/ostal dokaj enak & Frekvenca & Delež $(\%)$ \\
\hline Povečal do $5 \%$ & 7 & 8,2 \\
\hline Povečal nad 5 do $10 \%$ & 2 & 2,4 \\
\hline Povečal nad ıo do $20 \%$ & 3 & 3,4 \\
\hline Povečal nad 20 do $35 \%$ & $\circ$ & 0,0 \\
\hline Povečal nad $35 \%$ & 1 & 1,2 \\
\hline Zmanjšal do $5 \%$ & I & $\mathrm{I}, 2$ \\
\hline Zmanjšal nad 5 do $10 \%$ & 4 & 4,8 \\
\hline Zmanjšal nad ıo do $20 \%$ & 4 & 4,8 \\
\hline Zmanjšal nad 20 do $35 \%$ & 3 & 3,4 \\
\hline Zmanjšal nad $35 \%$ & I & 1,2 \\
\hline Ostal dokaj enak & 59 & 69,4 \\
\hline Skupaj & 85 & 100,0 \\
\hline
\end{tabular}

Iz preglednice 44 je razvidno, da je največ $1 / \mathrm{m} / \mathrm{v}(74, \mathrm{I} \%)$ odgovorilo, da je tržni delež na tujem trgu v drugem p/o glede na prvo ostal dokaj enak, najmanj $(5,9 \%)$ jih je odgovorilo, da se je zmanjšal, $20 \% \mathrm{l} / \mathrm{m} / \mathrm{v}$ pa jih je odgovorilo, da se je povečal.

\section{Preglednica 44: Tržni delež na tujem trgu}

\section{Tržni delež na tujem trgu}

Frekvenca

$\operatorname{Delež~}(\%)$

Tržni delež na tujem trgu se je v obdobju 20II-2013 glede na obdobje 2008-20I0 povečal.

$17 \quad 20,0$

Tržni delež na tujem trgu se je v obdobju 20II-2013 glede na obdobje 2008-20I0 zmanjšal.

Tržni delež na tujem trgu je v obdobju 20II-2013 glede na obdobje 2008-20ı ostal dokaj enak.

$63 \quad 74,1$

Skupaj

85 IOO,O 
Iz preglednice 45 je razvidno, da je največ $\mathrm{l} / \mathrm{m} / \mathrm{v}$ ( $10,5 \%$ ) odgovorilo, da se jim je tržni delež na tujem trgu v drugem p/o glede na prvo p/o povečal, in sicer se je povečal do $5 \%$, tisti $1 / \mathrm{m} / \mathrm{v}(\mathrm{I}, 2 \%)$, ki pa so odgovorili, da se jim je zmanjšal, pa se je zmanjšal nad 5 do io \%, nad ıo do $20 \%$ in tudi enako nad $35 \%, 74, \mathrm{r} \% \mathrm{l} / \mathrm{m} / \mathrm{v}$ pa je odgovorilo, da je ostal dokaj enak.

\section{Preglednica 45: Tržni delež na tujem trgu se je povečal/zmanjšal/ostal dokaj enak}

\begin{tabular}{|c|c|c|}
\hline Tržni delež na tujem trgu se je povečal/zmanjšal/ostal dokaj enak & Frekvenca & $\operatorname{Delež}(\%)$ \\
\hline Povečal do $5 \%$ & 9 & 10,5 \\
\hline Povečal nad 5 do $10 \%$ & 6 & 7,0 \\
\hline Povečal nad to do $20 \%$ & I & 1,2 \\
\hline Povečal nad 20 do $35 \%$ & $\circ$ & ०,० \\
\hline Povečal nad $35 \%$ & I & 1,2 \\
\hline Zmanjšal do $5 \%$ & I & 1,2 \\
\hline Zmanjš̌l nad 5 do $10 \%$ & 2 & 2,4 \\
\hline Zmanjšal nad io do $20 \%$ & I & 1,2 \\
\hline Zmanjšal nad 20 do $35 \%$ & $\circ$ & 0,0 \\
\hline Zmanjšal nad $35 \%$ & I & 1,2 \\
\hline Ostal dokaj enak & 63 & 74,1 \\
\hline Skupaj & 85 & 100,0 \\
\hline
\end{tabular}

\section{Število zaposlenih}

Iz preglednice 46 je razvidno, da je največ $1 / \mathrm{m} / \mathrm{v}$ ( $55,7 \%$ ) odgovorilo, da je število zaposlenih $\mathrm{v}$ p/o ostalo nespremenjeno, najmanj $1 / \mathrm{m} / \mathrm{v}(\mathrm{I} 8,2 \%)$ je odgovorilo, da se je povečalo, $26,1 \% \mathrm{l} / \mathrm{m} / \mathrm{v}$ pa je odgovorilo, da se je zmanjšalo.

\section{Preglednica 46: Število zaposlenih}

\begin{tabular}{lll}
\hline Skupaj & 88 & 100,0
\end{tabular}


Iz preglednice 47 je razvidno, da se je tistim $1 / \mathrm{m} / \mathrm{v}(6,8 \%)$, ki se jim je $\mathrm{v}$ drugem $\mathrm{p} / \mathrm{o}$ glede na prvo $\mathrm{p} / \mathrm{o}$ število zaposlenih povečalo, to povečalo do $5 \%$, tistim (13,6 \%), ki se jim je zmanjšalo, se je zmanjšalo nad 5 do $10 \%, 55,7 \% \mathrm{l} / \mathrm{m} / \mathrm{v}$ pa jih je odgovorilo, da je število zaposlenih ostalo nespremenjeno.

Preglednica 47: Število zaposlenih se je povečalo/zmanjšalo/ostalo nespremenjeno

\begin{tabular}{|c|c|c|}
\hline Število zaposlenih se je povečalo/zmanjšalo/ostalo nespremenjeno & Frekvenca & Delež $(\%)$ \\
\hline Povečalo do $5 \%$ & 6 & 6,8 \\
\hline Povečalo nad 5 do ro \% & 5 & 5,7 \\
\hline Povečalo nad ıo do $20 \%$ & $\circ$ & 0,0 \\
\hline Povečalo nad 20 do $35 \%$ & I & $\mathrm{I}, \mathrm{I}$ \\
\hline Povečalo nad $35 \%$ & 4 & 4,6 \\
\hline Zmanjšalo do $5 \%$ & 3 & 3,4 \\
\hline Zmanjšalo nad 5 do ıo \% & 12 & 13,6 \\
\hline Zmanjšalo nad ıo do $20 \%$ & 6 & 6,8 \\
\hline Zmanjšalo nad 20 do $35 \%$ & 2 & 2,3 \\
\hline Zmanjšalo nad $35 \%$ & $\circ$ & 0,0 \\
\hline Ostalo nespremenjeno & 49 & 55,7 \\
\hline Skupaj & 88 & 100,0 \\
\hline
\end{tabular}

\section{Donosnost}

$\mathrm{Na}$ naslednji dve vprašanji so anketiranci lahko odgovorili tako, da so ocenili stopnjo svojega strinjanja z zapisanimi trditvami tako, da so ob vsaki obkrožili (izbrali) eno številko na 5-stopenjski lestvici ( 1 - sploh se ne strinjam, 2 - ne strinjam se, 3 - se niti ne strinjam niti strinjam, 4 strinjam se, 5 - popolnoma se strinjam).

Iz preglednice 48 je razvidno, da so $1 / \mathrm{m} / \mathrm{v}$ v zvezi z donosnostjo $\mathrm{v}$ obdobju 20 I I-20I3 najvišjo oceno (povprečna vrednost $=3,87$ ) namenili dejavniku Razmerje med dobičkom in trajnim kapitalom oz. med dolgoročnimi obveznostmi sredstev - gre za donosnost vloženega kapitala (ROE), najnižjo oceno (povprečna vrednost $=3,58$ ) pa so namenili dejavniku Donosnost vloženih sredstev - gre za naložbe, ki so razmerje med dobičkom in sredstvi, vloženimi v naložbo (ROI).

Iz preglednice 49 je razvidno, da so $1 / \mathrm{m} / \mathrm{v}$ pri merjenju učinkovitosti uporabe znanja najvišjo oceno (povprečna vrednost $=4,42$ ) namenili dejavniku Učenje je dolžnost in pravica vseh zaposlenih, najnižjo (povpreč- 
na vrednost $=3,78)$ pa dejavniku Učinke uporabljenega znanja spremljamo z različnimi kazalniki (npr. BSC, ${ }^{\prime}$ angl. Balance Scorecard itd.).

Preglednica 48: Zadovoljstvo z donosnostjo v obdobju 20 I I-2013

Donosnost vloženih sredstev (angl. return on investments - ROI) - gre za naložbe, ki so razmerje med dobičkom in sredstvi, vloženimi v naložbo.

Dobiček glede na sredstva ali obveznosti do virov sredstev (angl. return on assets - ROA) - razmerje med dobičkom in vloženimi sredstvi delničarja (lastnika), kar pomeni, da gre za donosnost lastnega kapitala.

$84 \quad 3,71 \quad 0,769$

Razmerje med dobičkom in trajnim kapitalom oz. med dolgoročnimi obveznostmi sredstev (angl. return on equity - ROE) - gre za donosnost $84 \quad 3,87$ 0,915 vloženega kapitala.

Preglednica 49: Merjenje učinkovitosti uporabe znanja

\begin{tabular}{|c|c|c|c|c|c|}
\hline Merjenje učinkovitosti uporabe znanja & $\mathbf{N}$ & Min. & Maks. & $\begin{array}{c}\text { Povprečna } \\
\text { vrednost }(\mathbf{I}-5)\end{array}$ & $\begin{array}{l}\text { Standardni } \\
\text { odklon }\end{array}$ \\
\hline Učinke uporabljenega znanja spremljamo po občutku. & 88 & I & 5 & 4,23 & 0,840 \\
\hline Spremljamo znižanje stroškov zaradi uporabe znanja. & 88 & 2 & 5 & 4,06 & o,889 \\
\hline $\begin{array}{l}\text { Spremljamo vpliv uporabljenega znanja na dodano } \\
\text { vrednost zaposlenega. }\end{array}$ & 88 & I & 5 & 4,08 & 0,973 \\
\hline Učinka uporabljenega znanja ne spremljamo. & 87 & 2 & 5 & 3,98 & 1,067 \\
\hline $\begin{array}{l}\text { Spremljamo razmerje med naložbami v znanje in } \\
\text { finančno donosnostjo. }\end{array}$ & 88 & 2 & 5 & 4,06 & 0,998 \\
\hline $\begin{array}{l}\text { Učinke uporabljenega znanja spremljamo z različnimi } \\
\text { kazalniki (npr. BSC (angl. Balance scorecard) itd.). }\end{array}$ & 88 & I & 5 & 3,78 & 1,245 \\
\hline Učenje je dolžnost in pravica vseh zaposlenih. & 88 & 3 & 5 & 4,42 & 0,690 \\
\hline
\end{tabular}

Iz rezultatov posameznega vsebinskega sklopa smo pridobili dovolj podatkov, da smo za konstrukt človeški kapital, konstrukt organizacijska klima in konstrukt uspešnost poslovanja pripravili podatke za nadaljnjo

I BSC, angl. Balanced Scorecard, uravnotežen sistem kazalnikov (USK), ki meri uspešnost organizacije s štirih uravnoteženih vidikov kazalnikov, in sicer: finančnega, poslovanja s strankami, notranjih poslovnih procesov ter vidika učenja in rasti. Sistem omogoča spremljanje finančnih rezultatov ob hkratnem spremljanju napredka pri povečanju zmogljivosti in pridobivanju neopredmetenih sredstev, ki jih organizacije potrebujejo za prihodnjo rast (Kaplan in Norton 2000). 
obdelavo z metodami, s katerimi smo preučevali konstrukte s posameznimi hipotezami in njihovimi podhipotezami, s katerimi smo preverjali temeljno tezo. 



\section{Empirična analiza modela in preverjanje hipotez}

Na podlagi z anketiranjem zbranih podatkov smo izvedli analizo modela in preverili zastavljene hipoteze, upoštevajoč konstrukte človeški kapital, organizacijska klima in uspešnost poslovanja.

\section{Analiza komunalitet in ugotovitev faktorjev}

Ker je bilo v analizo vključenih veliko spremenljivk, smo uporabili faktorsko analizo, s katero smo poiskali novo množico spremenljivk, katerih število je bistveno manjše od števila opazovanih spremenljivk, vendar še vedno predstavljajo to, kar je skupnega opazovanim spremenljivkam. S faktorsko analizo smo torej poenostavili kompleksnost povezav med množico opazovanih spremenljivk z razkritjem skupnih razsežnosti ali faktorjev, ki omogočajo vpogled $\mathrm{v}$ osnovno strukturo podatkov. Najprej smo ugotavljali, ali lahko zveze med opazovanimi spremenljivkami pojasnimo z manjšim številom posredno opazovanih spremenljivk ali faktorjev.

Komunaliteta je mera razmerja pojasnjene variance z izločenimi faktorji (Field 2006). Izločene so bile vse spremenljivke, ki so imele komunalitete < od 0,3 (Field 2006, po Šifrer in Bren 201 I, 50). Želimo, da so vse komunalitete večje kot 0,3 , če je katera od komunalitet manjša, spremenljivko lahko izločimo iz nadaljnjih obdelav.

Za ekstrakcijsko metodo smo izbrali metodo največjega verjetja (ML - maximum likelihood) s poševnokotno (Oblimin) rotacijo (Klaneček 20IO, I27). Metodo največjega verjetja smo izbrali, ker problem faktorske analize rešuje iteracijsko, njeno osnovno načelo pa je iskanje najboljše ocene za reprodukcijo variančno-kovariančne matrike (Ferligoj 2004). 
Število faktorjev smo določili na osnovi:

- Kaiserjevega kriterija, tj. števila lastnih vrednosti spremenljivk, ki so večje kot $\mathrm{I}(\lambda>\mathrm{I})$;

- diagrama lastnih vrednosti (angl. Scree Plot);

- glede na interpretabilnost faktorjev.

\section{Eksplorativna faktorska analiza}

Za preverjanje posameznih konstruktov smo uporabili eksplorativno in konfirmativno faktorsko analizo, ki je skupno ime za nekaj multivariatnih statističnih metod. $S$ faktorsko analizo identificiramo ločene dimenzije v strukturi podatkov med velikim številom spremenljivk, pozneje pa še določimo stopnjo, do katere je vsaka spremenljivka pojasnjena z vsako dimenzijo. Na podlagi niza opazovanih odvisnih in neodvisnih spremenljivk skozi stopnje faktorske analize oblikujemo nove spremenljivke, t. i. faktorje. Faktorska analiza poišče latentne faktorje, ki delujejo v ozadju in tako prispevajo k oblikovanju spremenljivk. Če dobljenih rezultatov ne moremo najsmiselneje interpretirati, uporabimo rotacijo faktorjev, kjer poznamo: poševne rotacije (kjer so faktorji medsebojno odvisni) in pravokotne rotacije (kjer faktorji niso odvisni), $v$ obeh primerih pa sta deleža pojasnjene variance in komunalitete enaka (Gomezelj Omerzel 2009, 63). Pred uporabo faktorske analize je treba preveriti primernost podatkov za njeno uporabo, saj mora med spremenljivkami obstajati določena stopnja povezanosti. Pogledati moramo korelacijsko matriko, ki je matrika parcialnih korelacij med spremenljivkami ali stopnja, do katere faktorji pojasnjujejo drug drugega.

Uporabimo pa tudi KMO- (angl. Keiser-Meyer-Olkin Measure of Sampling Adequacy, mera ustreznosti vzorca) in Bartlettov preizkus (angl. Bartlett's test of Sphericity). Statistika KMO meri moč povezave, z Bartlettovim preizkusom pa preverjamo, ali je korelacijska matrika enotska. Če ni enotska, so opazovane spremenljivke do določene mere povezane.

Eksplorativna faktorska analiza poskuša večjo skupino spremenljivk zmanjšati v manjše število spremenljivk - faktorjev. Konfirmativna faktorska analiza že predvideva obstoj takih faktorjev in potem preveri, ali to drži ali ne (Aaker in Day 1990; Kim in Mueller 1987). Ponavadi se eksplorativna analiza uporablja za analizo konstruktov, $s$ konfirmativno pa potrdimo veljavnost rezultatov prve (Antončič 2000). 
Modeliranje $\mathrm{z}$ linearnimi strukturnimi enačbami, konfirmativna faktorska analiza in strukturni model

Za namen analize odnosov med več spremenljivkami v sistemu regresijskih enačb smo z uporabo modeliranja z linearnimi strukturnimi enačbami ob uporabi programov SPSS in AMOS razvili strukturni model. Tega smo nato še nadgradili z določenimi povezavami med spremenljivkami.

Model je sestavljen iz dveh delov. Najprej smo v prvem delu na osnovi konfirmativne faktorske analize, ki smo jo izvedli za konstrukt človeški kapital, konstrukt organizacijska klima in konstrukt uspešnost poslovanja, potrdili obstoj iz teorije izhajajoče predvidene faktorske strukture. Nato smo na podlagi konfirmativne faktorske analize določili standardizirane uteži merjenih spremenljivk oz. trditev za posamezne spremenljivke oz. dimenzije preučevanih konstruktov. Nato smo na podlagi vrednosti standardiziranih uteži prikazali, katere trditve najbolj pojasnjujejo faktorje. Ob tem smo na osnovi Cronbachovega $\alpha$-koeficienta preverili še zanesljivost dobljenih faktorjev.

Hair idr. (2006) opredeljujejo, da raziskovalec z multivariatnimi tehnikami občiajno želi razširiti svojo statistično učinkovitost, ker je v številnih primerih naloga raziskovalcev v tem, da želijo raziskati skupino medsebojno povezanih odnosov, kar ni mogoče z eno samo multivariatno tehniko. Zato so razvili tehniko strukturirano modeliranje enačb (angl. structural equation modelling - SEM), za katero je značilna sposobnost ocenjevanja multiplih in medsebojno povezanih odvisnosti in hkrati tudi sposobnost vključevanja latentnih spremenljivk posameznih konstruktov (v našem primeru konstruktov človeški kapital, organizacijska klima in uspešnost poslovanja), kjer lahko latentne spremenljivke ponazorimo z eno ali več opazovanimi spremenljivkami, pri pojasnjevanju odnosov pa se upoštevajo tudi merske napake omenjenih spremenljivk. Modeliranje strukturnih enačb (SEM) (Milfelner, Mumel in Snoj 2006) vključuje in kombinira tako elemente faktorske analize $\mathrm{z}$ namenom identifikacije osnovnih konstruktov oz. idej, ki definirajo neodvisno spremenljivko, kot tudi elemente regresijske analize. SEM omogoča izračunavanje ocen zanesljivosti, ključnih za vrednotenje vsakega osnovnega konstrukta, kot tudi merjenje posrednega in neposrednega vpliva med spremenljivkami v modelu (Myers in Mullet 2003). 



\section{Analiza konstrukta človeški kapital}

Vse dimenzije konstrukta človeški kapital smo najprej kodirali. Vključene dimenzije smo izbrali zato, ker smo želeli človeški kapital preučiti z različnimi spremenljivkami, ki smo jih vključili v anketni vprašalnik in nadaljnjo analizo, da bi s tem potrdili kar največji vpliv dejavnikov na uspešnost poslovanja turističnih agencij (v nadaljevanju uspešnost poslovanja).

Kodiranje trditev z oceno stopenj strinjanj posamezne dimenzije konstrukta človeški kapital

Izvorna kodiranja dimenzij konstrukta človeškega kapitala v anketnem vprašalniku, kodiranja v SPSS in njihova uporaba $\mathrm{v}$ analizah ter trditve, ki se nanašajo na posamezne trditve, so prikazani v preglednici so.

Preglednica so: Izvorna kodiranja dimenzij ČK v anketnem vprašalniku, kodiranja v SPSS in njihova uporaba $v$ analizah ter trditve, ki se nanašajo na posamezne trditve

Izvorna kodiran- Kodiranja v SPSS in nji-

ja vvprašalniku hova uporabavanalizah

Pridobivanje znanja - trditve

\begin{tabular}{|c|c|c|}
\hline Q16a & pridobivi & Uporabljamo internet. \\
\hline Q16b & pridobiv2 & Spremljamo strokovno literaturo. \\
\hline Qi6c & pridobiv3 & Turistična agencija zaposlene spodbuja pri nadaljnjem izobraževanju. \\
\hline Q16d & pridobiv4 & $\begin{array}{l}\text { Dijakom/študentom omogočamo opravljanje prakse, seminarskih } \\
\text { ali diplomskih nalog na primeru naše turistične agencije. }\end{array}$ \\
\hline Q16e & pridobivs & Izvajamo interna usposabljanja. \\
\hline Q16f & pridobiv6 & Sodelujemo z zunanjimi sodelavci. \\
\hline
\end{tabular}




\begin{tabular}{lll} 
Q16g & pridobiv7 & Spodbujamo sodelovanje z drugimi podjetji pri raznih delih. \\
Q16h & pridobiv8 & $\begin{array}{l}\text { Izven t. a. se udeležujemo različnih seminarjev, delavnic in tudi } \\
\text { turističnih sejmov. }\end{array}$ \\
Q16i & pridobiv9 & Sodelujemo z zunanjimi raziskovalnimi institucijami. \\
\hline
\end{tabular}

132

\section{Shranjevanje znanja - trditve}

\begin{tabular}{|c|c|c|}
\hline Q $17 \mathrm{a}$ & shranjevanjer & $\begin{array}{l}\text { Shranjujemo zapise (imamo arhiv) o svojem nastanku, razvoju in } \\
\text { viziji delovanja. }\end{array}$ \\
\hline$Q_{17} b$ & shranjevanje2 & $\begin{array}{l}\text { Shranjujemo znanje (imamo arhiv) o izvedbi in vsebini delovnih } \\
\text { procesov. }\end{array}$ \\
\hline$Q_{17 c}$ & shranjevanjez & $\begin{array}{l}\text { Imamo dobro organizirano dokumentacijo o znanju in dosežkih } \\
\text { zaposlenih. }\end{array}$ \\
\hline Q17d & shranjevanje 4 & Podpiramo objavo uspehov. \\
\hline
\end{tabular}

\section{Prenos znanja - trditve}

\begin{tabular}{|c|c|c|}
\hline Qi8a & prenosi & Dobro počutje v turistični agenciji pozitivno vpliva na prenos znanja. \\
\hline Qisb & prenos2 & Vsak zaposleni je usposobljen za opravljanje več delovnih nalog. \\
\hline Qi8c & prenos3 & Vpeljano imamo timsko in projektno delo. \\
\hline Qi8d & prenos 4 & $\begin{array}{l}\text { Na voljo imamo prostore, kjer se lahko zadržujemo in neformal- } \\
\text { no družimo. }\end{array}$ \\
\hline Qi8e & prenoss & $\begin{array}{l}\text { Imamo učinkovit sistem svetovanja in mentoriranja mlajših in } \\
\text { novih sodelavcev. }\end{array}$ \\
\hline Qi8f & prenos6 & Pomanjkanje znanja ovira njegovo širjenje. \\
\hline Q $18 \mathrm{~g}$ & prenos7 & $\begin{array}{l}\text { Pripravljeni smo posredovati svoje znanje, vendar imamo za to } \\
\text { premalo časa. }\end{array}$ \\
\hline Qish & prenos 8 & Svoje zaposlene spodbujamo k objavljanju njihovih dosežkov. \\
\hline Q $18 \mathrm{i}$ & prenos9 & $\begin{array}{l}\text { Imamo učinkovit računalniško podprt sistem za dostop in iskanje } \\
\text { po lastnih zbirkah znanja. }\end{array}$ \\
\hline$Q_{1} 8 j$ & prenosio & $\begin{array}{l}\text { Organiziramo različne interne izobraževalne delavnice, s katerimi } \\
\text { spodbujamo izmenjavo mnenj. }\end{array}$ \\
\hline Q18k & prenosil & $\begin{array}{l}\text { Zaposleni imamo premalo komunikacijskih spretnosti, potrebnih } \\
\text { za prenos znanja. }\end{array}$ \\
\hline Q18l & prenosi2 & Organizirane imamo predstavitve in razprave o dosežkih zaposlenih. \\
\hline$Q_{1} 8 \mathrm{~m}$ & prenosi3 & $\begin{array}{l}\text { Turistična agencija ne stimulira dovolj pretoka znanja med } \\
\text { zaposlenimi. }\end{array}$ \\
\hline Q18n & prenosi4 & $\begin{array}{l}\text { Zaposleni skrivamo svoje znanje pred sodelavci, ker menimo, da s } \\
\text { tem povečujemo svojo konkurenčno prednost pred njimi. }\end{array}$ \\
\hline Q180 & prenosis & $\begin{array}{l}\text { Premoremo učinkovit računalniško podprt sistem za vizualno } \\
\text { komunikacijo med zaposlenimi (npr. videokonferenca). }\end{array}$ \\
\hline
\end{tabular}




\begin{tabular}{|c|c|c|}
\hline & & Uporaba znanja - trditve \\
\hline Q19a & uporabar & Koristne predloge uporabimo v praksi. \\
\hline Q $19 b$ & uporabaz & Uspešno uporabljamo lastne izkušnje za razreševanje novih izzivov. \\
\hline Q $19 \mathrm{c}$ & uporabaz & Uspešno uporabljamo svoje znanje v delovnih procesih. \\
\hline Q19d & uporaba 4 & Zaposlene spodbujamo, da novo znanje uporabijo v praksi. \\
\hline Qige & uporabas & Najboljše predloge nagradimo. \\
\hline Qigf & uporaba6 & Turistična agencija uspešno izkoristi potenciale svojih zaposlenih. \\
\hline Qigg & uporaba7 & $\begin{array}{l}\text { Posameznike nagradimo glede na uspešno uporabljeno novo znan- } \\
\text { je - finančne spodbude. }\end{array}$ \\
\hline Qigh & uporaba8 & Pogovarjamo se o svojih potrebah po znanju. \\
\hline Qigi & uporabag & $\begin{array}{l}\text { Posameznike nagradimo glede na uspešno uporabljeno novo znanje } \\
\text { - nefinančne spodbude. }\end{array}$ \\
\hline \multirow[t]{2}{*}{$Q_{19 j}$} & uporabaio & $\begin{array}{l}\text { Znanja med zaposlenimi je dovolj, problematična je le njegova } \\
\text { uporaba. }\end{array}$ \\
\hline & & Vrsta (način) izobraževanja - trditve \\
\hline Q2oaa & vrsti & Imamo interni akt o učeči se organizaciji. \\
\hline$Q_{2} \circ a b$ & vrst2 & Izobraževanje poteka predvsem znotraj (interno) turistične agencije. \\
\hline $\mathrm{Q}_{2} \mathrm{Oac}$ & vrst3 & Izobraževanje poteka predvsem zunaj (eksterno) turistične agencije. \\
\hline Q2oad & vrst 4 & Imamo sestanke s profesionalnimi svetovalci. \\
\hline Q2oae & vrst5 & Prebiramo strokovno literaturo. \\
\hline Q2oaf & vrst6 & Informacije iščemo na internetu. \\
\hline Q2oag & vrst7 & Obiskujemo sejme, razstave, konference. \\
\hline Q2oah & vrst8 & Izmenjujemo mnenja z drugimi turističnimi agencijami. \\
\hline Q2oai & vrst9 & Udeležujemo se študijskih izletov/potovanj. \\
\hline Q2oaj & vrstio & Izobražujemo se s področja trženja \\
\hline Q2oak & vrstiI & Izobražujemo se s področja računovodstva. \\
\hline Q2oal & vrstI2 & $\begin{array}{l}\text { Izobražujemo se s področij geografije, zgodovine in umetnostne } \\
\text { zgodovine. }\end{array}$ \\
\hline Q2oam & vrsti3 & Izobražujemo se s področja tujih jezikov. \\
\hline Q2oan & vrsti4 & Izobražujemo se s področja vodenja. \\
\hline Q20ao & vrstis & Izobražujemo se s področja komunikacije. \\
\hline \multirow[t]{2}{*}{ Q2oap } & vrsti6 & $\begin{array}{l}\text { Izobražujemo se s področja odnosov med zaposlenimi in odnosov } \\
\text { do strank. }\end{array}$ \\
\hline & & Čas izobraževanja - trditve \\
\hline Q2oba & casai & Interno izobraževanje poteka znotraj delovnega časa. \\
\hline Q2obb & casa2 & Eksterno izobraževanje poteka znotraj delovnega časa. \\
\hline$Q_{2} \circ b c$ & casaz & Udeležujemo se večdnevnih oblik izobraževanj (tečaji, seminarji). \\
\hline Q2obd & casa4 & Udeležujemo se enodnevnih oblik izobraževanj (tečaji, seminarji). \\
\hline
\end{tabular}




\section{Eksplorativna faktorska analiza za konstrukt človeški kapital}

Eksplorativno faktorsko analizo za konstrukt človeški kapital smo izvedli v skladu s postopkom, navedenim v empirični analizi modela in preverjanja hipotez.

Za konstrukt človeški kapital so vsi faktorji pokazali visoko zanesljivost: Cronbachova alfa za Prenos_A $=0,891$, za Vrst_A $=0,835$, za Vrst_B $=0,914$, za UporabaVrst $=0,830$, za CasaVrst $=0,837$, za Prenos_B $=0,783$, za Shranjev $=0,848$, za Pridobiv $=0,777$ in za Uporaba $=0,852$.

Opomba: prenos znanja - nestimulativni (Prenos_A), izobraževanje s področja trženja (Vrst_A), izobraževanje s področja komuniciranja (Vrst_B), uporaba znanja na lastnih izkušnjah (UporabaVrst), čas izobraževanja (CasaVrst), prenos znanja - timski (Prenos_B), shranjevanje znanja (Shranjev), pridobivanje znanja (Pridobiv), uporaba znanja (Uporaba).

V preglednici s I so podatki za KMO in BT v okviru konstrukta človeški kapital.

Preglednica s r: KMO in BT v okviru konstrukta človeški kapital

KMO ustreznosti vzorca

\begin{tabular}{lcc}
\hline & Predviden Hi-kvadrat & 2797,001 \\
BT & df & 630 \\
& sig. & 0,000 \\
\hline
\end{tabular}

Opomba: $\mathrm{df}=$ (angl. degrees of freedom $)$ stopinje prostosti pokažejo, ali so med opazovano in ocenjevano matriko podatkov statistično značilne razlike; sig. (angl. significance $)$ = statistična značilnost ali stopnja značilnosti je tveganje, $s$ katerim lahko trdimo, da rezultate iz vzorca lahko posplošimo na celotno populacijo ( $p<0,05)$.

KMO-mera ustreznosti vzorca nam pokaže, ali so podatki primerni za faktorsko analizo. Višja kot je mera KMO, ustreznejši so podatki. Optimalno je, da je KMO večja od o,8, še sprejemljiva pa je med o,5 in o,6 (ك̌ifrer in Bren 20II, 49).

Z Bartlettovim testom preverjamo ničelno hipotezo, da je izvirna korelacijska matrika enotska. Kot je bilo že zapisano, morajo biti korelacije med spremenljivkami primerne (ne previsoke in ne prenizke). Če bi bila korelacijska matrika enotska, bi bile vse korelacije med spremenljivkami o, kar pomeni, da so vse spremenljivke med seboj neodvisne in zato zmanjšanje njihovega števila ni možno. Ničelno hipotezo bomo torej zavrnili, če je vrednost statistične značilnosti Bartlettovega testa (statistična značilnost) manjša od 0,05 . 
Iz raziskave izhaja, da $\mathrm{v}$ našem primeru vrednost $\mathrm{KMO}$ znaša 0,762 in vrednost statistične značilnosti o,ooo, korelacijska matrika pa ni enotska. Tako lahko torej zaključimo, da so naši podatki primerni za faktorsko analizo.

Naslednji korak je bila analiza komunalitet posameznih spremenljivk glede na postavljeno merilo, da bomo izločili vse spremenljivke, ki imajo komunaliteto manjšo od 0,3 (Šifrer in Bren 20II, 50). Tako so v preglednici 52 prikazane samo spremenljivke, ki imajo najvišjo ekstrahirano komunaliteto pri spremenljivki vrstıs z vrednostjo 0,999 in najnižjo pri spremenljivki casa2 z vrednostjo $0,5 \mathrm{I} 4$.

$\mathrm{V}$ preglednici 52 so prikazane komunalitete spremenljivk konstrukta človeški kapital.

Preglednica 52: Komunalitete spremenljivk konstrukta človeški kapital

\begin{tabular}{|c|c|c|}
\hline Spremenljivke & Začetne & Končne \\
\hline vrstis & 0,912 & 0,999 \\
\hline prenosi4 & 0,903 & $0,88_{1}$ \\
\hline prenosiz & 0,879 & 0,855 \\
\hline vrsti4 & 0,870 & 0,787 \\
\hline vrsti6 & 0,852 & 0,745 \\
\hline prenosi2 & 0,850 & 0,842 \\
\hline shranjevanjez & 0,839 & 0,833 \\
\hline vrstio & 0,824 & 0,768 \\
\hline uporabaz & 0,822 & 0,869 \\
\hline vrsts & $\circ, 8 \mathrm{II}$ & 0,552 \\
\hline shranjevanjez & $0,8 \circ 8$ & $0,76 \mathrm{I}$ \\
\hline uporabay & $0,8 \circ 3$ & 0,816 \\
\hline uporabai & 0,797 & 0,790 \\
\hline casaz & 0,796 & 0,514 \\
\hline casaz & 0,793 & 0,934 \\
\hline uporaba8 & 0,792 & 0,720 \\
\hline vrst9 & 0,792 & 0,725 \\
\hline vrstiI & 0,787 & 0,783 \\
\hline shranjevanjeı & 0,784 & 0,834 \\
\hline prenosiI & $0,78 \mathrm{I}$ & 0,656 \\
\hline pridobiv6 & 0,752 & 0,907 \\
\hline pridobiv7 & 0,743 & 0,756 \\
\hline uporabas & 0,735 & 0,624 \\
\hline
\end{tabular}


Iz podatkov $\mathrm{v}$ preglednici 53 , ki nam prikazuje lastne vrednosti in skupno pojasnjeno varianco izločenih faktorjev za konstrukt človeški kapital, ugotovimo, da je izločenih devet faktorjev, kar prikazuje tudi kolenski diagram za konstrukt človeški kapital (slika 4). Varianca vseh devetih izločenih faktorjev znaša $66,55 \%$.

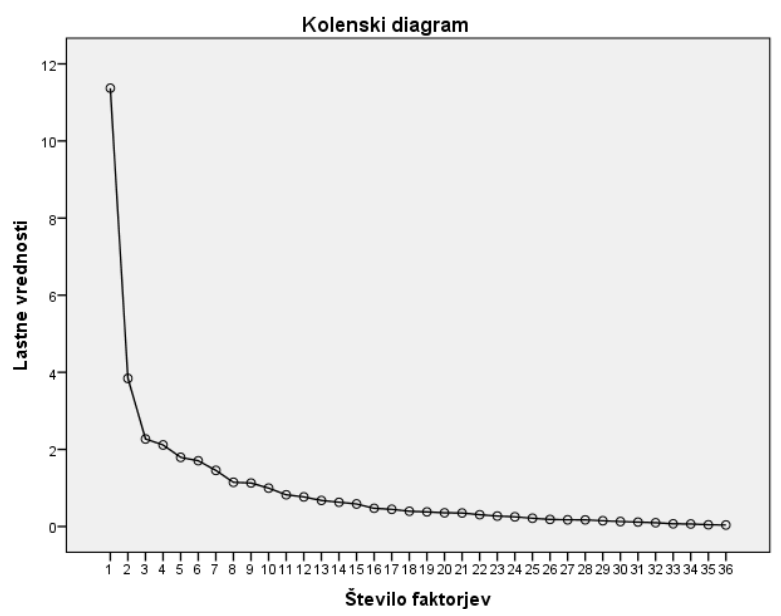

Slika 4 : Kolenski diagram lastnih vrednosti za konstrukt človeški kapital in faktorji s pripadajočimi dejavniki konstrukta človeški kapital

Faktorji s pripadajočimi dejavniki konstrukta človeški kapital:

- Prvifaktor smo poimenovali prenos znanja - nestimulativni, pripadajo pa mu naslednji dejavniki konstrukta človeški kapital: prenosi3, prenosi 4, prenosi2, prenosi I in prenos7.

- Drugi faktor smo poimenovali izobraževanje s področja trženja (TA), pripadajo pa mu naslednji dejavniki konstrukta človeški kapital: vrstı I, vrstıo, vrst9 in vrst8.

- Tretji faktor smo poimenovali izobraževanja s področja komuniciranja, pripadajo pa mu naslednji dejavniki konstrukta človeški kapital: vrsti5, vrsti 4 in vrsti6.

- Četrti faktor smo poimenovali uporaba znanja pri lastnih izkušnjah, pripadajo pa mu naslednji dejavniki konstrukta človeški kapital: uporaba2, uporaba I, uporabaz in vrst6.

- Peti faktor smo poimenovali čas izobraževanja, pripadajo pa mu naslednji dejavniki konstrukta človeški kapital: casa3, casa4, casa2, vrst7 in vrst5. 
- Šesti faktor smo poimenovali prenos znanja - timski, pripadajo pa mu naslednji dejavniki konstrukta človeški kapital: prenos3, prenos6, prenos5, prenos4, prenosi in prenos8.

- Sedmi faktor smo poimenovali shranjevanje znanja, pripadajo pa mu naslednji dejavniki konstrukta človeški kapital: shranjevanjeI, shranjevanjez in shranjevanjez.

- Osmi faktor smo poimenovali pridobivanje znanja, pripadajo pa mu naslednji dejavniki konstrukta človeški kapital: pridobiv6, pridobiv7 in pridobivs.

- Deveti faktor smo poimenovali uporaba znanja, pripadajo pa mu naslednji dejavniki konstrukta človeški kapital: uporaba7, uporaba8 in uporabas.

Preglednica 53: Lastne vrednosti in skupna pojasnjena varianca izločenih faktorjev za konstrukt človeški kapital

\begin{tabular}{|c|c|c|c|c|c|c|c|}
\hline \multirow{2}{*}{ Faktor } & \multicolumn{3}{|c|}{ Začetne lastne vrednosti } & \multicolumn{3}{|c|}{ Ekstrahirana vsota kvadratov uteži } & \multirow{2}{*}{$\begin{array}{c}\begin{array}{c}\text { Rotirana vso- } \\
\text { ta kvadratov } \\
\text { uteži }\end{array} \\
\text { Skupaj }\end{array}$} \\
\hline & Skupaj & $\begin{array}{c}\text { Delež } \\
\text { variance }\end{array}$ & $\begin{array}{c}\text { Kumulativni } \\
\text { delež }\end{array}$ & Skupaj & $\begin{array}{c}\text { Delež } \\
\text { variance }\end{array}$ & $\begin{array}{c}\text { Kumulativni } \\
\text { delež }\end{array}$ & \\
\hline I & 11,370 & 31,582 & 31,582 & 6,070 & 16,862 & 16,862 & 7,553 \\
\hline 2 & 3,842 & 10,672 & 42,255 & 6,264 & $I 7,4 O I$ & 34,263 & 4,769 \\
\hline 3 & 2,271 & 6,308 & 48,562 & 3,584 & 9,954 & 44,217 & 6,271 \\
\hline 4 & 2,115 & 5,875 & 54,438 & 1,771 & 4,918 & 49,136 & 3,942 \\
\hline 5 & 1,794 & 4,984 & 59,421 & 1,416 & 3,932 & 53,068 & 6,507 \\
\hline 6 & 1,706 & 4,739 & 64,160 & 1,524 & 4,232 & 57,300 & 4,966 \\
\hline 7 & $\mathrm{I}, 457$ & 4,046 & 68,206 & 1,260 & 3,501 & $60,8 \circ \mathrm{I}$ & 7,314 \\
\hline 8 & $\mathrm{I}, \mathrm{I} 47$ & 3,185 & $7 \mathrm{I}, 39 \mathrm{I}$ & $\mathrm{I}, \mathrm{IO} 7$ & 3,074 & 63,875 & 4,131 \\
\hline 9 & 1,129 & 3,135 & 74,526 & 0,963 & 2,674 & 66,549 & 7,474 \\
\hline 10 & 0,996 & 2,767 & 77,293 & & & & \\
\hline II & 0,823 & 2,285 & 79,578 & & & & \\
\hline 12 & 0,769 & 2,135 & $8 \mathrm{I}, 7 \mathrm{I} 4$ & & & & \\
\hline 13 & 0,677 & 1,880 & 83,594 & & & & \\
\hline 14 & 0,629 & 1,747 & $85,34 \mathrm{I}$ & & & & \\
\hline 15 & 0,585 & 1,626 & 86,967 & & & & \\
\hline 16 & 0,472 & 1,312 & 88,279 & & & & \\
\hline 17 & 0,446 & $\mathrm{I}, 239$ & 89,518 & & & & \\
\hline I8 & 0,397 & $\mathrm{I}, \mathrm{IO2}$ & 90,620 & & & & \\
\hline 19 & 0,380 & 1,055 & 91,675 & & & & \\
\hline
\end{tabular}




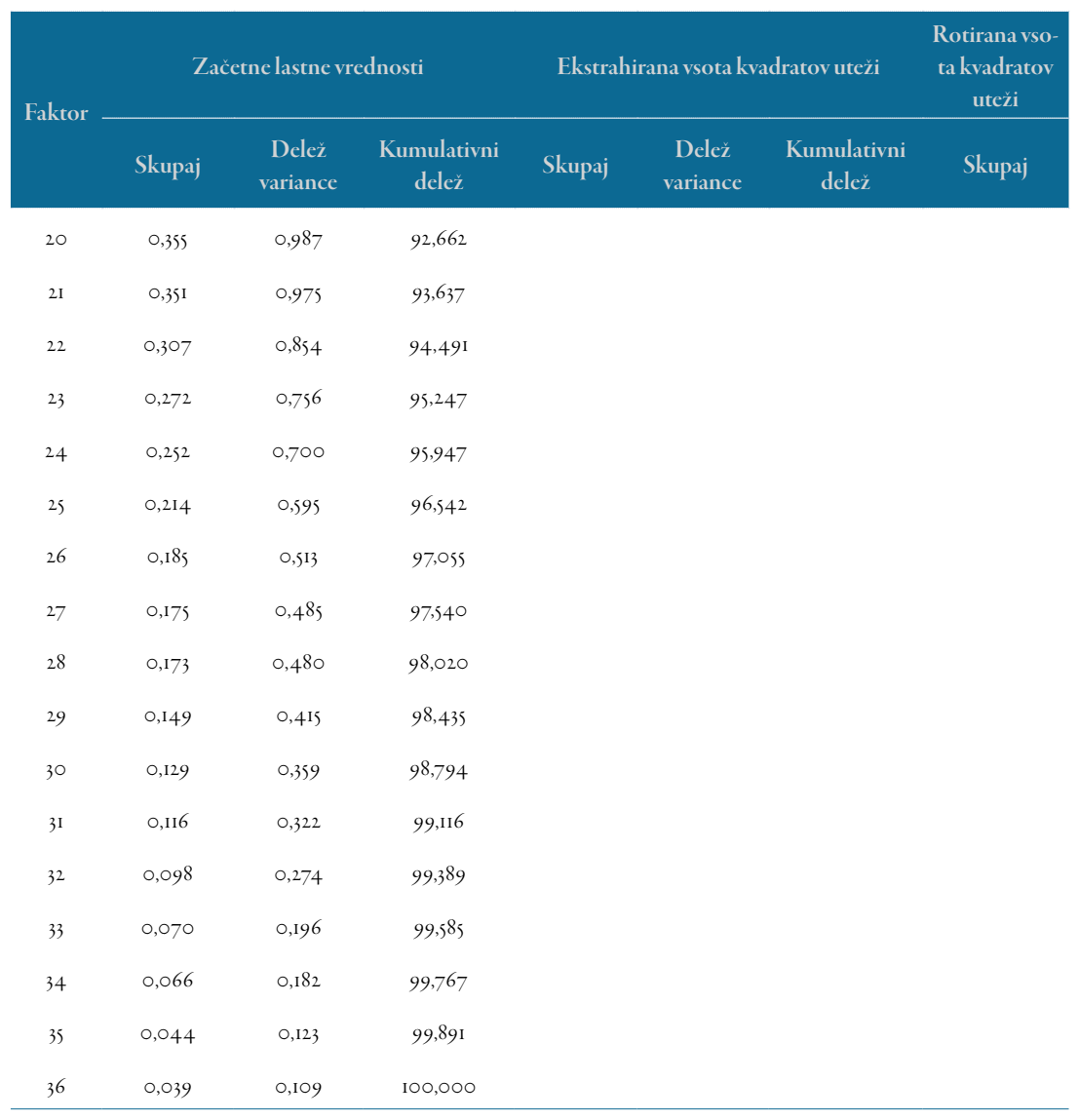

Metoda ekstrakcije: metoda največjega verjetja (angl. Maximum Likelihood).

V nadaljevanju sledi preglednica 54, ki prikazuje rotirano faktorsko matriko za konstrukt človeški kapital.

Rotirana faktorska matrika prikazuje, da se spremenljivke, ki smo jih ohranili, enakomerno porazdelijo med faktorje in imajo večje uteži le pri enem faktorju.

Za to končno rešitev smo izločili spremenljivke, ki so se bodisi vezale na dva faktorja bodisi so imele nizko vrednost (pod o,3) bodisi njihove razporeditve $\mathrm{v}$ posamezen faktor ni bilo mogoče smiselno interpretirati, zato smo jih izločili. Te spremenljivkeso bile: casa I, prenosıo, prenosis, prenos2, prenos9, pridobivi, pridobiv2, pridobiv3, pridobiv4, pridobiv8, pridobiv9, shranjevanje4, uporabaio, uporaba4, uporaba6, uporaba9, vrst I, vrsti 2 , vrst 3 , vrst2, vrst 3 in vrst 4 . 
Preglednica 54: Rotirana faktorska matrika za konstrukt človeški kapital

\begin{tabular}{|c|c|c|c|c|c|c|c|c|c|}
\hline \multirow{2}{*}{ Spremenljivka } & \multicolumn{9}{|c|}{ Faktor } \\
\hline & I & 2 & 3 & 4 & 5 & 6 & 7 & 8 & 9 \\
\hline prenosi3 & 0,991 & & & & & & & & \\
\hline prenosi4 & 0,834 & & & & & & & & \\
\hline prenosi2 & 0,823 & & & & & & & & \\
\hline prenosil & 0,766 & & & & & & & & \\
\hline prenos7 & 0,619 & & & & & & & & \\
\hline vrstiI & & 0,919 & & & & & & & \\
\hline vrstio & & 0,875 & & & & & & & \\
\hline vrst9 & & 0,725 & & & & & & & \\
\hline vrst8 & & 0,515 & & & & & & & \\
\hline vrstis & & & 10,038 & & & & & & \\
\hline vrsti 4 & & & 0,876 & & & & & & \\
\hline vrsti6 & & & 0,743 & & & & & & \\
\hline uporabaz & & & & 0,933 & & & & & \\
\hline uporabai & & & & 0,910 & & & & & \\
\hline uporabaz & & & & 0,730 & & & & & \\
\hline vrst 6 & & & & 0,306 & & & & & \\
\hline casaz & & & & & $\mathrm{I}, \mathrm{OI} 7$ & & & & \\
\hline casa4 & & & & & 0,699 & & & & \\
\hline casa2 & & & & & 0,512 & & & & \\
\hline vrst7 & & & & & $0,49 \mathrm{I}$ & & & & \\
\hline vrst5 & & & & & 0,373 & & & & \\
\hline prenos3 & & & & & & 0,722 & & & \\
\hline prenos6 & & & & & & 0,603 & & & \\
\hline prenoss & & & & & & $0,58 \mathrm{I}$ & & & \\
\hline prenos4 & & & & & & 0,510 & & & \\
\hline prenosi & & & & & & 0,391 & & & \\
\hline prenos8 & & & & & & 0,320 & & & \\
\hline shranjevanjes & & & & & & & 1,060 & & \\
\hline shranjevanjez & & & & & & & 0,917 & & \\
\hline shranjevanjez & & & & & & & 0,548 & & \\
\hline pridobiv6 & & & & & & & & 1,012 & \\
\hline pridobiv7 & & & & & & & & 0,830 & \\
\hline pridobivs & & & & & & & & 0,428 & \\
\hline uporabay & & & & & & & & & 0,877 \\
\hline uporaba8 & & & & & & & & & 0,733 \\
\hline uporabas & & & & & & & & & 0,694 \\
\hline
\end{tabular}

Metoda ekstrakcije: metoda največjega verjetja (angl. Maximum Likelihood); metoda rotacije: Promax with Kaiser Normalization: poševna rotacija, rotacija, konvergirana v sedmih iteracijah. 
Posamezne spremenljivke smo združili v faktorje ali sestavljene spremenljivke, saj smo $s$ tem skušali poenostaviti kompleksnost povezav med množico opazovanih spremenljivk $\mathrm{z}$ razkritjem skupnih razsežnosti ali faktorjev, ki omogočajo vpogled $\mathrm{v}$ osnovno strukturo podatkov.

Sledi preglednica $55 \mathrm{z}$ matriko korelacij med faktorji konstrukta človeški kapital.

Preglednica 55: Matrika korelacij med faktorji konstrukta človeški kapital

\begin{tabular}{cccccccccc} 
Faktor & I & 2 & 3 & 4 & 5 & 6 & 7 & 8 & 9 \\
\hline I & 1,000 & 0,166 & 0,462 & $-0,018$ & 0,472 & 0,349 & 0,620 & 0,391 & 0,558 \\
2 & 0,166 & 1,000 & 0,328 & 0,402 & 0,303 & 0,331 & 0,197 & 0,207 & 0,353 \\
3 & 0,462 & 0,328 & 1,000 & 0,170 & 0,433 & 0,262 & 0,474 & 0,318 & 0,579 \\
4 & $-0,018$ & 0,402 & 0,170 & 1,000 & 0,318 & 0,232 & 0,239 & 0,111 & 0,221 \\
5 & 0,472 & 0,303 & 0,433 & 0,318 & 1,000 & 0,344 & 0,561 & 0,291 & 0,478 \\
6 & 0,349 & 0,331 & 0,262 & 0,232 & 0,344 & 1,000 & 0,383 & 0,212 & 0,424 \\
7 & 0,620 & 0,197 & 0,474 & 0,239 & 0,561 & 0,383 & 1,000 & 0,311 & 0,595 \\
8 & 0,391 & 0,207 & 0,318 & 0,111 & 0,291 & 0,212 & 0,311 & 1,000 & 0,415 \\
9 & 0,558 & 0,353 & 0,579 & 0,221 & 0,478 & 0,424 & 0,595 & 0,415 & 1,000 \\
\hline
\end{tabular}

Metoda ekstrakcije: metoda največjega verjetja (angl. Maximum Likelihood); metoda rotacije: Promax with Kaiser Normalization: poševna rotacija.

Najnižja vrednost korelacije je -o,or 8 in najvišja vrednost korelacije je 0,620 , kar pomeni, da so korelacije ustrezne, saj nobena ne presega vrednosti 0,7 , ki pomeni visoko korelacijo.

\section{Konfirmativna faktorska analiza za konstrukt človeški kapital}

Namen izvedbe konfirmativne faktorske analize je bil potrditi (konfirmirati) obstoj specifične in vnaprej predvidene faktorske strukture na področju človeškega kapitala.

Eksplorativno analizo ponavadi uporabimo za analizo konstruktov, $s$ konfirmativno pa potrdimo veljavnosti rezultatov prve (Antončič 2000).

Eksplorativna faktorska analiza, s katero smo analizirali posamezne konstrukte v celotnem modelu človeški kapital, je pokazala, da je konstrukt človeški kapital sestavljen iz naslednjih dimenzij:

- prenos znanja - nestimulativni (Prenos_A);

- izobraževanje s področja trženja (Vrst_A);

- izobraževanje s področja komuniciranja (Vrst_B); 
- uporaba znanja pri lastnih izkušnjah (UporabaVrst);

- čas izobraževanja (CasaVrst);

- prenos znanja - timski (Prenos_B);

- shranjevanje znanja (Shranjev);

- pridobivanje znanja (Pridobiv);

- uporaba znanja (Uporaba).

Sledi ponazoritev diagrama poti za konstrukt človeški kapital (slika 5), ki prikazuje vsebovane latentne spremenljivke: prenos znanja nestimulativni, izobraževanje/trženje, izobraževanja/komuniciranje, uporaba znanja pri lastnih izkušnjah, čas izobraževanja, prenos znanja - timski, shranjevanje znanja, pridobivanje znanja, uporaba znanja. V modelu je sodelovalo 36 opazovanih spremenljivk, kot je razvidno na sliki 5. Povezanost med latentnimi in opazovanimi spremenljivkami je enosmerna. Medsebojna povezanost med latentnimi spremenljivkami je obojestranska.

Konstrukt človeški kapital je pokazal visoko zanesljivost, saj so vrednosti Cronbachevega koeficienta ${ }^{1} \alpha=0,891$ za Prenos_A, $\alpha=0,835$ za Vrst_A, $\alpha=0,914$ za Vrst_B, $\alpha=0,830$ za UporabaVrst, $\alpha=0,837$ za CasaVrst, $\alpha=0,783$ za Prenos_B, $\alpha=0,848$ za Shranjev, $\alpha=0,777$ za Pridobiv in $\alpha=0,852$ za Uporabo visoke, razen za Pridobiv, kjer je vrednost nekoliko nižja, vendar vseeno še zelo dobra.

Na sliki $s$ je prikazan diagram konstrukta človeški kapital s standardizirano rešitvijo.

Konstrukt človeški kapital ima visoko konvergenco v smislu koeficientov, saj so regresijski koeficienti vseh faktorjev pri skoraj vseh spremenljivkah dokaj visoki (preglednica 56) in statistično značilni $(\mathrm{p}<\mathrm{o}, \mathrm{O} \mathrm{I})$. Navedeno pomeni, da lahko z veliko zanesljivostjo trdimo, da ti vplivi obstajajo tudi na populaciji in ne le na vzorcu turističnih agencij.

Vrednost RMSEA znaša 0,093 , kar pomeni, da je po tem merilu prilagajanje modela konstrukta človeškega kapitala sprejemljivo. Ostali indeksi $(\mathrm{CFI}=0,8 \circ 8$, NFI $=0,672$, RFI $=0,628)$ so razmeroma nizki, vendar ocenjujemo, da je prilagajanje modela sprejemljivo (slika 5 ).

Cronbachov koeficient $\alpha$ (v nadaljevanju CK $\alpha$ ) je najpogostejša mera za ugotavljanje zanesljivosti kazalnikov. Zanesljivost merjenja s to mero lahko označimo po Hairu idr. (2006): zgledno, če je $\mathrm{CK} \alpha \geq 0,80$; zelo dobro, če je $\mathrm{CK} \alpha \geq 0,7$ in manjši od o,80; zmerno, če je $\mathrm{CK} \alpha \geq 0,60$ in manjši od o,70, ter komaj sprejemlivo, če je CK $\alpha$ manjši od o,60. 


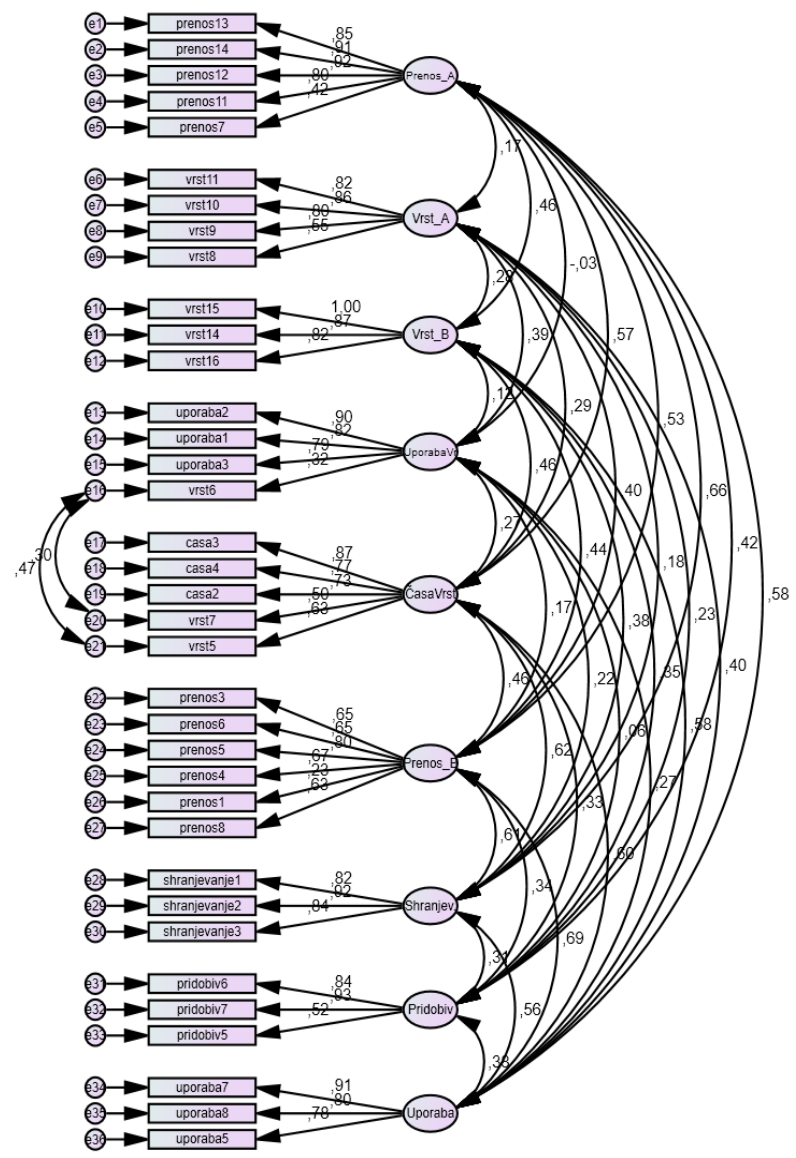

Slika 5: Diagram konstrukta človeški kapital s standardizirano rešitvijo

Hi-kvadrat $=1.048,9, \mathrm{df}=556, \mathrm{p}=0,000$

Opombe: $\mathrm{CFI}^{2}=0,808, \mathrm{NFI}^{3}=0,672, \mathrm{RFI}^{4}=0,628, \mathrm{RMSEA}^{5}=0,093$, Cronbach alfa $=0,89 \mathrm{I} \mathrm{za}$ Prenos_A, o,835 za Vrst_A, o,9 I 4 za Vrst_B, o,8 30 za UporabaVrst, o,8 37 za CasaVrst, o, 78 z za Prenos_B, o,848 za Shranjev, o 777 za Pridobiv in o,852 za Uporaba.

Legenda: е г ... e36 = faktorji napake.

2 CFI (angl. Comparative fit index) je izboljšana različica NFI. Ima tudi iste lastnosti, in sicer zavzema vrednosti med o in I, višje vrednosti pomenijo boljši model. Lahko rečemo, da je model dober, ko so vrednosti večje od 0,9 .

3 NFI (angl. Normed fit index) ima vrednost med o in I in bolj kot je blizu I, boljši je model.

$4 \quad$ RFI (angl. Relative fit index) - tudi ta je podoben NFI, vrednosti blizu i kažejo zelo dobro prileganje.

5 RMSEA (angl. Root mean square error of approximation) je kazalec, ki poleg vrednosti izraža tudi interval zaupanja za to vrednost. Manjša absolutna vrednost kazalca pomeni boljšo veljavnost modela. 


\section{V preglednici 56 so prikazani standardizirani regresijski koeficienti in stopnje značilnosti za konstrukt človeški kapital.}

Preglednica 56: Standardizirani regresijski koeficienti in stopnje značilnosti za konstrukt človeški kapital

\begin{tabular}{|c|c|c|c|c|}
\hline Spremenljivka & Smer vpliva & Spremenljivka & $\begin{array}{l}\text { Standardiziran } \\
\text { regresijski koeficient }\end{array}$ & Stopnja značilnosti (p) \\
\hline prenosi3 & $<--$ & Prenos_A & 0,853 & Fiksni \\
\hline prenosi4 & $<--$ & Prenos_A & 0,908 & $* * *$ \\
\hline prenosi2 & $<--$ & Prenos_A & 0,921 & $* *$ \\
\hline prenosil & $<--$ & Prenos_A & $0,8 \circ 3$ & *** \\
\hline prenos7 & $<--$ & Prenos_A & 0,419 & $* * *$ \\
\hline vrstiI & $<--$ & Vrst_A & 0,823 & Fiksni \\
\hline vrstio & $<--$ & Vrst_A & 0,863 & $* * *$ \\
\hline vrst9 & $<--$ & Vrst_A & 0,796 & $* * *$ \\
\hline vrst8 & $<--$ & Vrst_A & 0,552 & ${ }^{* * *}$ \\
\hline vrstis & $<--$ & Vrst_B & 0,998 & Fiksni \\
\hline vrsti4 & $<--$ & Vrst_B & 0,866 & $* * *$ \\
\hline vrsti6 & $<--$ & Vrst_B & 0,816 & ${ }^{* * *}$ \\
\hline uporabaz & $<--$ & UporabaVrst & 0,898 & Fiksni \\
\hline uporabai & $<--$ & UporabaVrst & 0,820 & $* *$ \\
\hline uporabaz & $<--$ & UporabaVrst & 0,787 & ${ }^{* * *}$ \\
\hline vrst6 & $<--$ & UporabaVrst & 0,323 & ${ }^{* * *}$ \\
\hline $\mathrm{Casaz}_{3}$ & $<--$ & CasaVrst & 0,869 & Fiksni \\
\hline casa4 & $<--$ & CasaVrst & 0,766 & ${ }^{* * *}$ \\
\hline casa2 & $<--$ & CasaVrst & 0,726 & $* *$ \\
\hline vrst7 & $<--$ & CasaVrst & 0,499 & ${ }^{* * *}$ \\
\hline vrsts & $<--$ & CasaVrst & 0,629 & ${ }^{* * *}$ \\
\hline prenos3 & $<--$ & Prenos_B & 0,651 & Fiksni \\
\hline prenos6 & $<--$ & Prenos_B & 0,649 & $* * *$ \\
\hline prenoss & $<--$ & Prenos_B & $0,8 \circ 0$ & $* * *$ \\
\hline prenos 4 & $<-$ & Prenos_B & 0,674 & $* * *$ \\
\hline prenosi & $<--$ & Prenos_B & 0,231 & 0,032 \\
\hline prenos8 & $<--$ & Prenos_B & 0,633 & $* * *$ \\
\hline shranjevanjer & $<--$ & Shranjev & 0,818 & Fiksni \\
\hline shranjevanjez & $<--$ & Shranjev & 0,916 & $* * *$ \\
\hline shranjevanjez & $<--$ & Shranjev & $0,84 \mathrm{I}$ & $* * *$ \\
\hline
\end{tabular}




\begin{tabular}{lcccc} 
Spremenljivka & Smervpliva & Spremenljivka & $\begin{array}{c}\text { Standardiziran } \\
\text { regresijski kocficient }\end{array}$ & Stopnja značilnosti (p) \\
pridobiv6 & $<--$ & Pridobiv & 0,842 & Fiksni \\
pridobiv7 & $<---$ & Pridobiv & 0,928 & $* *$ \\
pridobiv5 & $<--$ & Pridobiv & 0,524 & $* * *$ \\
uporaba7 & $<--$ & Uporaba & 0,907 & Fiksni \\
uporaba8 & $<--$ & Uporaba & 0,805 & $* * *$ \\
uporabas & $<---$ & Uporaba & $0,78 \mathrm{I}$ & $* * *$ \\
\hline
\end{tabular}

Legenda: ${ }^{* * *}$ - p (stopnja značilnosti) je < o,o0 I, fiksni - stopnje značilnosti ne preverjamo, saj je v merskem delu strukturnega modela ena od uteži merljivih spremenljivk vedno fiksirana na $\mathrm{I}$.

Iz preglednice 56 in modela konstrukta človeškega kapitala (slika 5) izhaja, da je najmočnejša povezanost med opazovano spremenljivkam vrstıs in latentno spremenljivko Vrst_B in znaša 0,998 . Najšibkejša pa je povezava med opazovano spremenljivko vrst6 in latentno spremenljivko UporabaVrst in znaša 0,323 . 


\section{Analiza konstrukta organizacijska klima}

Pri preučevanju konstrukta organizacijska klima smo trditve iz anketnega vprašalnika v zvezi z oceno stopnje strinjanja s posameznimi trditvami iz določenega področja najprej kodirali v programu SPSS, kar smo potem uporabili pri nadaljnji analizi.

\section{Kodiranje trditev $\mathrm{z}$ oceno stopenj strinjanj posamezne dimenzije} konstrukta organizacijska klima

Posamezne dimenzije konstrukta organizacijska klima smo izbrali zato, ker so bile dobro desetletje vključene v projekt raziskovanja in spremljanja organizacijske klime v slovenskih organizacijah, poimenovan $\mathrm{SiOK}$, slovenska organizacijska klima. S posameznimi dimenzijami konstrukta tudi laže izvedemo primerjavo med posameznimi storitvenimi in proizvodnimi podjetji, tudi longitudinalno.

Vse dimenzije konstrukta organizacijska klima smo najprej kodirali. Vključene dimenzije smo izbrali zato, da bi s tem potrdili kar največji vpliv dejavnikov organizacijske klime na uspešnost poslovanja.

Izvorna kodiranja, ki se nanašajo na dimenzije konstrukta organizacijska klima $\mathrm{v}$ anketnem vprašalniku, kodiranja v SPSS in njihova uporaba $v$ analizah ter trditve, ki se nanašajo na posamezne trditve, so prikazani v preglednici 57. 
Preglednica 57: Izvorna kodiranja dimenzij konstrukta $O K$ v anketnem vprašalniku, kodiranja v SPSS in njihova uporaba v analizah ter trditve, ki se nanašajo na posamezne trditve

Odnos do kakovosti - trditve

\begin{tabular}{|c|c|c|}
\hline Q21a & kakovostı & Čutimo se odgovorne za kakovost svojega dela. \\
\hline $\mathrm{Q}_{21} \mathrm{~b}$ & kakovost2 & Prispevamo k doseganju standarda kakovosti. \\
\hline $\mathrm{Q}_{21 \mathrm{C}}$ & kakovost3 & $\begin{array}{l}\text { Druge sodelavce in oddelke (trženje, računovodstvo) } \\
\text { obravnavamo kot svoje spoštovane stranke. }\end{array}$ \\
\hline \multirow[t]{2}{*}{ Q21d } & kakovost 4 & Standard in cilj kakovosti sta jasna. \\
\hline & & Inovativnost in iniciativnost - trditve \\
\hline $\mathrm{Q}_{22 \mathrm{a}}$ & inovi & Izboljšave predlagamo vsi - ne le vodstvo. \\
\hline $\mathrm{Q}_{22} \mathrm{~b}$ & inov2 & Delovne metode stalno izboljšujemo in posodabljamo. \\
\hline $\mathrm{Q}_{222 \mathrm{C}}$ & inov 3 & Zavedamo se, da so izboljšave nujne. \\
\hline \multirow[t]{2}{*}{$\mathrm{Q}_{22} \mathrm{~d}$} & inov4 & Pripravljeni smo prevzeti tveganje za uveljavitev svojih zamisli. \\
\hline & & Strokovna usposobljenost in učenje - trditve \\
\hline Q23a & usposobr & Učimo se drug od drugega. \\
\hline $\mathrm{Q}_{23} \mathrm{~b}$ & usposob2 & Usposobljeni smo za svoje delo. \\
\hline $\mathrm{Q}_{233}$ & usposob $_{3}$ & Pri usposabljanju se upoštevajo naše želje. \\
\hline $\mathrm{Q}_{23} \mathrm{~d}$ & usposob $_{4}$ & Omogočeno nam je potrebno usposabljanje za dobro delo. \\
\hline \multirow[t]{2}{*}{ Q23e } & usposobs & Sistem za naše usposabljanje je dober. \\
\hline & & Motivacija in zavzetost - trditve \\
\hline $\mathrm{Q}_{24} 4 \mathrm{a}$ & motivi & Zavzeti smo za svoje delo. \\
\hline $\mathrm{Q}_{24} \mathrm{~b}$ & motiv2 & Pripravljeni smo na dodaten napor, kadar je to potrebno. \\
\hline $\mathrm{Q}_{24 \mathrm{C}}$ & motiv3 & Postavljene imamo zelo visoke zahteve za delovno uspešnost \\
\hline $\mathrm{Q}_{24} 4 \mathrm{~d}$ & motiv4 & Dober delovni rezultat se hitro opazi in se pohvali. \\
\hline
\end{tabular}

\section{Notranje komuniciranje in informiranje - trditve}

\begin{tabular}{|c|c|c|}
\hline Q25a & komunir & Delovni sestanki so redni. \\
\hline $\mathrm{Q}_{25} \mathrm{~b}$ & komuniz & $\begin{array}{l}\text { Sodelavci se med sabo pogovarjamo sproščeno, prijateljsko in } \\
\text { enakopravno. }\end{array}$ \\
\hline$Q_{25} \mathrm{C}$ & komuniz & O poslovnih zadevah smo obveščeni na razumljiv način. \\
\hline $\mathrm{Q}_{25} \mathrm{~d}$ & komuni4 & $\begin{array}{l}\text { Vodstvo nam posreduje dovolj informacij, da lahko delo dobro } \\
\text { opravljamo. }\end{array}$ \\
\hline
\end{tabular}




\section{Vodenje (delegiranje) dela - trditve}

\begin{tabular}{|c|c|c|}
\hline $\mathrm{Q}_{2} 6 \mathrm{a}$ & vodenjer & Pri svojem delu smo samostojni. \\
\hline$Q_{2} 6 \mathrm{~b}$ & vodenjez & $\begin{array}{l}\text { Vodstvo nas spodbuja k sprejemanju večje odgovornosti za } \\
\text { naše delo. }\end{array}$ \\
\hline $\mathrm{Q}_{2} 6 \mathrm{c}$ & vodenjez & Nimamo ukazovalnega vodenja. \\
\hline$Q_{2} 6 \mathrm{~d}$ & vodenje4 & Vodstvo se z nami pogovarja o delovnih rezultatih. \\
\hline \multirow[t]{2}{*}{ Q26e } & vodenjes & Vodstvo od nas sprejema utemeljene pripombe glede vodenja. \\
\hline & & Notranji odnosi - trditve \\
\hline$Q_{27} \mathrm{a}$ & odnosir & Cenimo delo svojih sodelavcev. \\
\hline $\mathrm{Q}_{27} \mathrm{~b}$ & odnosiz & Med sabo mnogo bolj sodelujemo kot tekmujemo. \\
\hline$Q_{27 C}$ & odnosiz & Odnosi med sodelavci so dobri. \\
\hline $\mathrm{Q}_{27} \mathrm{~d}$ & odnosi4 & Konflikte rešujemo v skupno korist. \\
\hline \multirow[t]{2}{*}{$Q_{27 \mathrm{e}}$} & odnosis & Med sabo si zaupamo. \\
\hline & & Poznavanje poslanstva, vizije in ciljev - trditve \\
\hline $\mathrm{Q}_{2} 8 \mathrm{a}$ & poslanstvor & $\begin{array}{l}\text { Imamo jasno oblikovano poslanstvo (svoj dolgoročni razlog } \\
\text { obstoja in delovanja). }\end{array}$ \\
\hline $\mathrm{Q}_{2} 8 \mathrm{~b}$ & poslanstvo2 & Cilje turistične agencije sprejemamo za svoje. \\
\hline $\mathrm{Q}_{2} 8 \mathrm{C}$ & poslanstvo3 & Cilji, ki jih moramo s sodelavci doseči, so realni. \\
\hline $\mathrm{Q}_{28 \mathrm{~d}}$ & poslanstvo 4 & $\begin{array}{l}\text { Pri postavljanju ciljev poleg vodstva sodelujejo tudi drugi } \\
\text { sodelavci. }\end{array}$ \\
\hline \multirow[t]{2}{*}{$\mathrm{Q}_{28 \mathrm{e}}$} & poslanstvos & Politika in cilji so jasni vsem zaposlenim. \\
\hline & & Organiziranost dela - trditve \\
\hline Q29a & organiziı & Imamo jasno predstavo o tem, kaj se od nas pri delu pričakuje. \\
\hline$Q_{29} \mathrm{~b}$ & organizi2 & Razumemo svoj položaj v organizacijski shemi. \\
\hline Q $29 \mathrm{C}$ & organiziz & Zadolžitve so jasno opredeljene. \\
\hline Q29d & organizi 4 & Vodstvo odločitve sprejema pravočasno. \\
\hline \multirow[t]{2}{*}{ Q29e } & organizis & $\begin{array}{l}\text { Pri nas so pristojnosti in odgovornosti med sabo uravnotežene na } \\
\text { vseh ravneh. }\end{array}$ \\
\hline & & Pripadnost organizaciji - trditve \\
\hline Q3oa & pripadnosti & Zunaj turistične agencije pozitivno govorimo o njej. \\
\hline $\mathrm{Q}_{3} \circ \mathrm{b}$ & pripadnost2 & Zadovoljni smo, da smo zaposleni v tej turistični agenciji. \\
\hline $\mathrm{Q}_{3} \circ \mathrm{C}$ & pripadnost3 & Imamo velik ugled v okolju. \\
\hline Q3od & pripadnost 4 & Zaposlitev je varna oz. zagotovljena. \\
\hline
\end{tabular}


Razvoj kariere - trditve

\begin{tabular}{|c|c|c|}
\hline $\mathrm{Q}_{3}$ га & karierai & Vsi imamo realne možnosti za napredovanje. \\
\hline $\mathrm{Q}_{3} \mathrm{Ib}$ & kariera2 & Merila za napredovanje so jasna vsem. \\
\hline $\mathrm{Q}_{3} \mathrm{IC}$ & karieraz & Zadovoljni smo s sedanjim osebnim razvojem. \\
\hline \multirow[t]{2}{*}{$Q_{3}$ Id } & kariera4 & Vodilni vzgajajo svoje naslednike. \\
\hline & & Nagrajevanje - trditve \\
\hline Q32a & Nagrajevanji & $\begin{array}{l}\text { Uspešnost (doseganje nadpovprečnih delovnih rezultatov) se } \\
\text { praviloma vrednoti po dogovorjenih ciljih in standardih. }\end{array}$ \\
\hline $\mathrm{Q}_{32} \mathrm{~b}$ & Nagrajevanj2 & Razmerja med plačami zaposlenih so ustrezna. \\
\hline $\mathrm{Q}_{32 \mathrm{C}}$ & Nagrajevanj3 & $\begin{array}{l}\text { Tisti, ki smo bolj obremenjeni z delom, smo tudi ustrezno } \\
\text { stimulirani. }\end{array}$ \\
\hline $\mathrm{Q}_{32 \mathrm{~d}}$ & Nagrajevanj4 & Naše plače so enakovredne ravni plač na trgu. \\
\hline \multirow[t]{2}{*}{ Q32e } & Nagrajevanjs & Slabo narejenemu delu sledi graja oz. ustrezen ukrep. \\
\hline & & Zadovoljstvo zaposlenih - trditve \\
\hline Q33a & Zadovolj_zapi & Zdelom. \\
\hline $\mathrm{Q}_{33} \mathrm{~b}$ & Zadovolj_zap2 & S sodelavci. \\
\hline $\mathrm{Q}_{33 \mathrm{C}}$ & Zadovolj_zap3 & Z neposredno nadrejenim. \\
\hline Q33d & Zadovolj_zap4 & S stalnostjo zaposlitve. \\
\hline Q33e & Zadovolj_zaps & Z vodstvom. \\
\hline $\mathrm{Q}_{33} \mathrm{f}$ & Zadovolj_zap6 & Zdelovnim časom. \\
\hline Q33g & Zadovolj_zap7 & S statusom v turistični agenciji. \\
\hline Q33h & Zadovolj_zap8 & Z možnostmi za izobraževanje. \\
\hline $\mathrm{Q}_{33} \mathrm{i}$ & Zadovolj_zap9 & Z možnostmi za napredovanje (namestnik, vodja oddelka). \\
\hline Q33j & Zadovolj_zapı & Z delovnimi pogoji (oprema, prostor). \\
\hline $\mathrm{Q}_{33} \mathrm{k}$ & Zadovolj_zapı & Z višino plače. \\
\hline $\mathrm{Q}_{33} \mathrm{l}$ & Zadovolj_zapı2 & Z rednim izplačilom plače. \\
\hline
\end{tabular}

\section{Eksplorativna faktorska analiza za konstrukt organizacijska klima}

Eksplorativna faktorska analiza za konstrukt organizacijska klima ponazarja, da so vsi faktorji pokazali visoko zanesljivost (Cronbachova alfa za OdnosKakovMotiv $=0,8 \circ 9$, za Vodenje (delegiranje dela) $=0,894$, za Pripadnost $=0819$, za Kariera $=0,869$, za ZadovoljNagrajevanje $=0,77 \mathrm{I}$ in za Usposobljenost $=0,84 \mathrm{I}$ ).

Opomba: notranji odnosi (OdnosKakovMotiv), vodenje (delegiranje dela) (Vodenje), pripadnost organizaciji (Pripadnost), razvoj kariere (Ka- 
riera), zadovoljstvo zaposlenih in nagrajevanje (ZadovoljNagrajevanj), strokovna usposobljenost in učenje (Usposobljenost).

$\mathrm{V}$ preglednici 58 so podatki za $\mathrm{KMO}$ in $\mathrm{BT} \mathrm{v}$ okviru konstrukta organizacijska klima.

Preglednica 58: KMO in BT v okviru konstrukta organizacijska klima

Iz raziskave izhaja, da vrednost $\mathrm{KMO}$ znaša 0,770 in vrednost statistične značilnosti Bartlettovega testa $0,000(\mathrm{p}<0,05)$, kar pomeni, da so podatki ustrezni za izvedbo faktorske analize.

$\mathrm{V}$ preglednici 59 so prikazane komunalitete spremenljivk konstrukta organizacijska klima.

Analiza komunalitet posameznih spremenljivk je pokazala, da je imela najvišjo ekstrahirano komunaliteto spremenljivka usposob3 $\mathrm{z}$ vrednostjo 0,999 in najnižjo spremenljivka motiv2 z vrednostjo 0,274 .

Nato smo prikazali lastne vrednosti in pojasnjene variance izločenih faktorjev za konstrukt organizacijska klima.

Preglednica $60 \mathrm{z}$ lastnimi vrednostmi in s pojasnjenimi variancami izločenih šestih faktorjev za konstrukt organizacijska klima prikazuje, da je bilo izločenih šest faktorjev, kar prikazuje tudi kolenski diagram za konstrukt organizacijska klima (slika 6). Vrednost pojasnjene variance znaša 63,72\%, kar je v družboslovju sprejemljiva vrednost.

$\mathrm{Na}$ sliki 6 je prikazan kolenski diagram lastnih vrednosti za konstrukt organizacijska klima in faktorji s pripadajočimi dejavniki konstrukta organizacijska klima.

Faktorji s pripadajočimi dejavniki konstrukta organizacijska klima:

- Prvi faktor smo poimenovali notranji odnosi, pripadajo pa mu naslednji dejavniki konstrukta organizacijska klima: odnosiı, odnosi2, kakovost I, kakovost2, kakovost 3 in motiv2.

- Drugi faktor smo poimenovali vodenje (delegiranje dela), pripadajo pa mu naslednji dejavniki konstrukta organizacijska klima: vodenje4, vodenje3 in vodenjes.

- Tretji faktor smo poimenovali pripadnost organizaciji, pripadajo pa mu naslednji dejavniki konstrukta organizacijska klima: pripadnost 2, pripadnost 3 in pripadnostr. 
- Četrti faktor smo poimenovali razvoj kariere, pripadajo pa mu naslednji dejavniki konstrukta organizacijska klima: kariera2, kariera I in kariera3.

- Peti faktor smo poimenovali zadovoljstvo zaposlenih in nagrajevanje, pripadajo pa mu naslednji dejavniki konstrukta organizacijska klima: Zadovolj_zap9, Zadovolj_zapı , Zadovolj_zapı 2 in Nagrajevanjs.

- Šestifaktor smo poimenovali strokovna usposobljenost in učenje, pripadata pa mu naslednja dejavnika konstrukta organizacijska klima: usposob3 in usposob4.

Preglednica 59: Komunalitete spremenljivk konstrukta organizacijska klima

\begin{tabular}{|c|c|c|}
\hline Spremenljivke & Začetne & Končne \\
\hline usposob3 & 0,677 & 0,999 \\
\hline vodenje 4 & 0,774 & $0,9 \circ 8$ \\
\hline kariera2 & $0,78 \mathrm{I}$ & 0,879 \\
\hline Zadovolj_zap9 & 0,685 & 0,857 \\
\hline pripadnost2 & 0,713 & 0,819 \\
\hline karierai & 0,826 & 0,818 \\
\hline odnosiz & 0,727 & 0,752 \\
\hline pripadnost3 & 0,731 & 0,744 \\
\hline odnosi & 0,705 & 0,731 \\
\hline vodenjez & 0,740 & 0,730 \\
\hline vodenjes & 0,702 & 0,675 \\
\hline Zadovolj_zapio & 0,625 & 0,635 \\
\hline usposob4 & 0,676 & 0,614 \\
\hline karieraz & $0,56 \mathrm{I}$ & 0,523 \\
\hline Nagrajevanj5 & 0,492 & 0,450 \\
\hline kakovost3 & $0,55 \mathrm{I}$ & 0,445 \\
\hline pripadnosti & 0,462 & 0,424 \\
\hline kakovostı & 0,616 & 0,405 \\
\hline Zadovolj_zapı2 & 0,502 & 0,396 \\
\hline kakovost2 & 0,547 & 0,304 \\
\hline motiv2 & 0,529 & 0,274 \\
\hline
\end{tabular}

Metoda ekstrakcije: metoda največjega verjetja (angl. Maximum Likelihood). Med ponovitvami so se pojavile ena ali več komunalitet z oceno, večjo od I. 


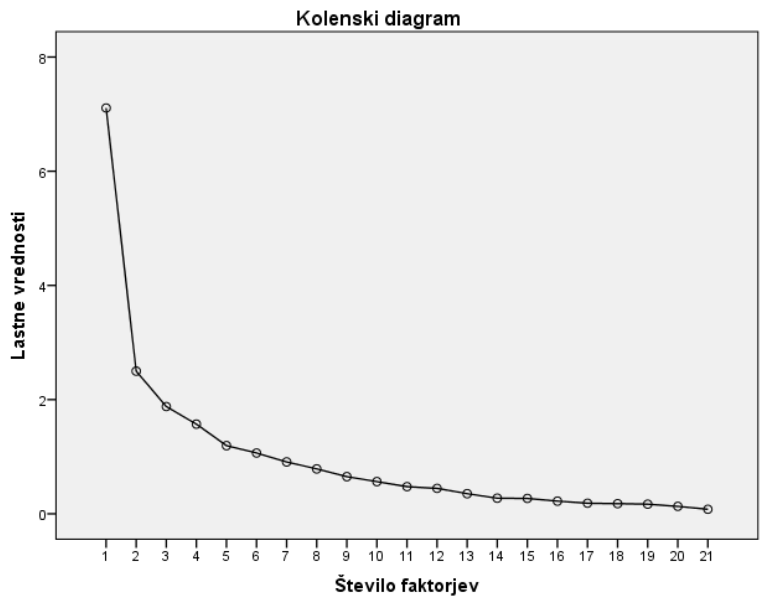

Slika 6 : Kolenski diagram lastnih vrednosti za konstrukt organizacijska klima in faktorji s pripadajočimi dejavniki konstrukta organizacijska klima

Preglednica 60: Lastne vrednosti in pojasnjene variance izločenih faktorjev za konstrukt organizacijska klima

\begin{tabular}{|c|c|c|c|c|c|c|c|}
\hline \multirow{2}{*}{ Faktor } & \multicolumn{3}{|c|}{ Začetne lastne vrednosti } & \multicolumn{3}{|c|}{ Ekstrahirana vsota kvadratov uteži } & \multirow{2}{*}{$\begin{array}{r}\begin{array}{r}\text { Rotirana vsota } \\
\text { kvadratov uteži }\end{array} \\
\text { Skupaj }\end{array}$} \\
\hline & Skupaj & $\begin{array}{c}\text { Delež } \\
\text { variance }\end{array}$ & $\begin{array}{c}\text { Kumulativni } \\
\text { delež }\end{array}$ & Skupaj & $\begin{array}{c}\text { Delež } \\
\text { variance }\end{array}$ & $\begin{array}{c}\text { Kumulativni } \\
\text { delež }\end{array}$ & \\
\hline I & 7,108 & 33,846 & 33,846 & 3,204 & 15,257 & 15,257 & 4,588 \\
\hline 2 & 2,498 & II, 897 & 45,742 & 4,645 & 22,119 & 37,376 & 4,014 \\
\hline 3 & $\mathrm{I}, 878$ & 8,944 & 54,686 & 1,985 & 9,450 & 46,826 & 3,547 \\
\hline 4 & 1,570 & 7,477 & 62,163 & 1,484 & 7,069 & 53,895 & $4,2 \mathrm{II}$ \\
\hline 5 & 1,193 & 5,683 & 67,846 & $\mathrm{I}, 254$ & 5,969 & 59,864 & 3,848 \\
\hline 6 & 1,065 & 5,071 & 72,918 & $0,8 \mathrm{I} \mathrm{O}$ & 3,859 & 63,724 & 3,885 \\
\hline 7 & 0,908 & 4,325 & 77,242 & & & & \\
\hline 8 & 0,787 & 3,746 & 80,988 & & & & \\
\hline 9 & $0,65 \mathrm{I}$ & 3,098 & 84,086 & & & & \\
\hline IO & 0,564 & 2,685 & 86,770 & & & & \\
\hline II & 0,475 & 2,262 & 89,032 & & & & \\
\hline 12 & 0,445 & 2,120 & 91,152 & & & & \\
\hline 13 & 0,352 & $\mathrm{I}, 678$ & 92,830 & & & & \\
\hline 14 & 0,273 & 1,301 & 94,132 & & & & \\
\hline I5 & 0,269 & 1,280 & 95,412 & & & & \\
\hline 16 & 0,222 & I, 057 & 96,469 & & & & \\
\hline 17 & 0,186 & 0,885 & 97,355 & & & & \\
\hline 18 & 0,178 & 0,847 & 98,202 & & & & \\
\hline
\end{tabular}




\begin{tabular}{|c|c|c|c|c|c|c|c|}
\hline \multirow{2}{*}{ Faktor } & \multicolumn{3}{|c|}{ Začetne lastne vrednosti } & \multicolumn{3}{|c|}{ Ekstrahirana vsota kvadratov uteži } & \multirow{2}{*}{$\begin{array}{c}\begin{array}{c}\text { Rotirana vsota } \\
\text { kvadratov uteži }\end{array} \\
\text { Skupaj }\end{array}$} \\
\hline & Skupaj & $\begin{array}{c}\text { Delež } \\
\text { variance }\end{array}$ & $\begin{array}{c}\text { Kumulativni } \\
\text { delež }\end{array}$ & Skupaj & $\begin{array}{c}\text { Delež } \\
\text { variance }\end{array}$ & $\begin{array}{c}\text { Kumulativni } \\
\text { delež }\end{array}$ & \\
\hline 19 & 0,168 & $0,8 \circ 2$ & 99,004 & & & & \\
\hline 20 & 0,130 & 0,619 & 99,623 & & & & \\
\hline 21 & 0,079 & 0,377 & 100,000 & & & & \\
\hline
\end{tabular}

Metoda ekstrakcije: metoda največjega verjetja (angl. Maximum Likelihood). Če so faktorji

povezani, vsota kvadratov uteži ne more biti dodana za namen pridobitve skupne variance.

\section{V preglednici 6r je prikazana rotirana faktorska matrika za kons- trukt organizacijska klima.}

Preglednica 6r: Rotirana faktorska matrika za konstrukt organizacijska klima

\begin{tabular}{|c|c|c|c|c|c|c|}
\hline \multirow{2}{*}{ Spremenljivke } & \multicolumn{6}{|c|}{ Faktor } \\
\hline & I & 2 & 3 & 4 & 5 & 6 \\
\hline odnosii & 0,849 & & & & & \\
\hline odnosiz & 0,843 & & & & & \\
\hline kakovostı & 0,624 & & & & & \\
\hline kakovost2 & 0,503 & & & & & \\
\hline kakovost3 & 0,432 & & & & & \\
\hline motiv2 & 0,340 & & & & & \\
\hline vodenje4 & & 10,030 & & & & \\
\hline vodenjez & & 0,814 & & & & \\
\hline vodenjes & & 0,790 & & & & \\
\hline pripadnost2 & & & 0,920 & & & \\
\hline pripadnost3 & & & $0,8 \circ 7$ & & & \\
\hline pripadnosti & & & 0,471 & & & \\
\hline karieraz & & & & 0,966 & & \\
\hline karieraI & & & & 0,789 & & \\
\hline karieraz & & & & 0,619 & & \\
\hline Zadovolj_zap9 & & & & & 0,912 & \\
\hline Zadovolj_zapı & & & & & 0,828 & \\
\hline Zadovolj_zapı2 & & & & & 0,510 & \\
\hline Nagrajevanjis & & & & & 0,335 & \\
\hline usposob3 & & & & & & $\mathrm{I}, 08 \mathrm{I}$ \\
\hline usposob4 4 & & & & & & $0,68 \circ$ \\
\hline
\end{tabular}

Metoda ekstrakcije: metoda največjega verjetja (angl. Maximum Likelihood); metoda rotacije: Promax with Kaiser Normalization. Rotacija konvergirana v sedmih iteracijah. 
Rotirana faktorska matrika prikazuje, da se spremenljivke, ki smo jih ohranili, enakomerno porazdelijo med faktorje in imajo večje uteži le pri enem faktorju.

Za to končno rešitev pri konstruktu organizacijska klima smo izločili spremenljivke, ki so se bodisi vezale na dva faktorja bodisi so imele nizko vrednost (pod o,2) bodisi njihove razporeditve v posamezen faktor ni bilo mogoče smiselno interpretirati, zato smo jih izločili. Te spremenljivke so bile: kakovost4, inovi, inov2, inov3, inov4, usposobı, usposob2, usposob5, motivi, motiv3, motiv4, komuni, komuni2, komuni3, komuni4, vodenjer, vodenje2, odnosi3, odnosi4, odnosis, poslanstvor, poslanstvo2, poslanstvo3, poslanstvo4, poslanstvo5, organiziı, organizi2, organizi3, organizi4, organizis, pripadnost4, kariera4, Nagrajevanjı, Nagrajevanj2, Nagrajevanj3, Nagrajevanj4, Zadovolj_zapı, Zadovolj_zap2, Zadovolj_ zap3, Zadovolj_zap4, Zadovolj_zaps, Zadovolj_zap6, Zadovolj_zap7, Zadovolj_zap8, Zadovolj_zapı I.

Posamezne spremenljivke smo združili v faktorje ali sestavljene spremenljivke, saj smo $s$ tem skušali poenostaviti kompleksnost povezav med množico opazovanih spremenljivk z razkritjem skupnih razsežnosti ali faktorjev, ki omogočajo vpogled v osnovno strukturo podatkov. V preglednici 62 so prikazane korelacije med faktorji konstrukta organizacijska klima.

Preglednica 62: Korelacije med faktorji konstrukta organizacijska klima

\begin{tabular}{ccccccc} 
Faktor & I & 2 & 3 & 4 & 5 & 6 \\
\hline 1 & 1,000 & 0,267 & 0,442 & 0,550 & 0,295 & 0,420 \\
2 & 0,267 & 1,000 & 0,212 & 0,322 & 0,448 & 0,508 \\
3 & 0,442 & 0,212 & 1,000 & 0,263 & 0,363 & 0,380 \\
4 & 0,550 & 0,322 & 0,263 & 1,000 & 0,453 & 0,324 \\
5 & 0,295 & 0,448 & 0,363 & 0,453 & 1,000 & 0,406 \\
6 & 0,420 & 0,508 & 0,380 & 0,324 & 0,406 & 1,000 \\
\hline
\end{tabular}

Metoda ekstrakcije: metoda največjega verjetja (angl. Maximum Likelihood); metoda rotacije: Promax with Kaiser Normalization.

Najnižja vrednost korelacije je 0,212 in najvišja vrednost je 0,550 , kar pomeni, da so korelacije ustrezne, saj nobena ne presega vrednosti $\circ, 7, \mathrm{ki}$ pomeni visoko korelacijo. 


\section{Konfirmativna faktorska analiza za konstrukt organizacijska klima}

Pri izvedbi konfirmativne analize za konstrukt organizacijska klima smo izhajali iz rezultatov eksplorativne faktorske analize, $s$ katero smo analizirali posamezne konstrukte $\mathrm{v}$ celotnem modelu organizacijske klime. Rezultati so pokazali, da je konstrukt organizacijska klima sestavljen iz naslednjih dimenzij:

- notranji odnosi (OdnosKakovMotiv);

- vodenje (delegiranje dela) (Vodenje);

- pripadnost organizaciji (Pripadnost);

- razvoj kariere (Kariera);

- zadovoljstvo zaposlenih in nagrajevanje (ZadovoljNagrajevanj);

- strokovna usposobljenost in učenje (Usposobljenost).

Sledi ponazoritev diagrama poti (slika 7) za konstrukt organizacijska klima, ki prikazuje, da je model vseboval naslednje latentne spremenljivke: notranji odnosi, vodenje (delegiranje dela), pripadnost organizaciji, razvoj kariere, zadovoljstvo zaposlenih in nagrajevanje, strokovna usposobljenost in učenje. V modelu je sodelovalo 2 I opazovanih spremenljivk. Povezanost med latentnimi in opazovanimi spremenljivkami je enosmer$\mathrm{na}$, in sicer $\mathrm{v}$ smeri od latentnih $\mathrm{k}$ opazovanim. Medsebojna povezanost med latentnimi spremenljivkami je obojestranska.

Tudi konstrukt orgnaizacijska klima je pokazal visoko zanesljivost, saj so vrednosti Cronbachevega koeficienta $\alpha=0,809$ za OdnosKakovMotiv, $\alpha=0,894$ za Vodenje (delegiranje dela), $\alpha=08$ I9 za Pripadnost, $\alpha=0,869$ za Kariera, $\alpha=0,77 \mathrm{I}$ za ZadovoljNagrajevanje in $\alpha=0,84 \mathrm{I}$ za Usposobljenost visoke (slika 7), nekoliko nižje le pri ZadovoljNagrajevanje, kjer vrednost znaša 0,771 .

Pri konstruktu organizacijska klima so standardizirani regresijski koeficienti vseh šestih faktorjev pri skoraj vseh spremenljivkah dokaj visoki (preglednica 63) in statistično značilni ( $\mathrm{p}<\mathrm{o,00I}$ ). Navedeno pomeni, da lahko z veliko zanesljivostjo trdimo, da ti vplivi obstajajo tudi pri populaciji in ne le pri vzorcu turističnih agencij.

Vrednost RMSEA znaša o,094, kar pomeni, da je po tem merilu prilagajanje modela sprejemljivo. Ostali indeksi $(\mathrm{CFI}=0,868$, NFI $=0,765$, $\mathrm{RFI}=0,7 \mathrm{I} 4)$ pa so tudi tukaj razmeroma nizki. 


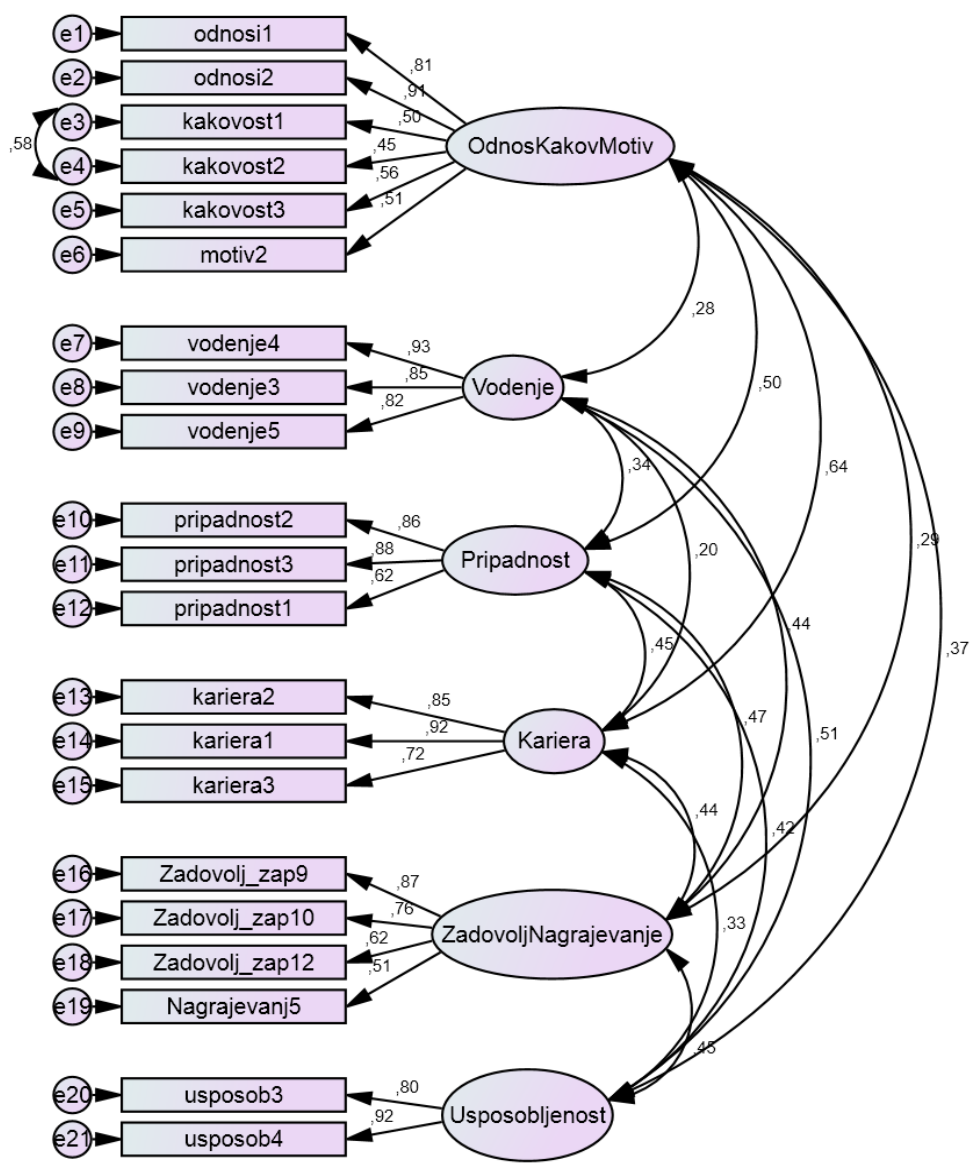

\section{Slika 7: Diagram konstrukta organizacijska klima s standardizirano rešitvijo}

Hi-kvadrat $=330,0, \mathrm{df}=173, \mathrm{P}=0,00$

Opombe: $\mathrm{CFI}=0,868, \mathrm{NFI}=0,765, \mathrm{RFI}=0,7 \mathrm{I} 4, \mathrm{RMSEA}=0,094$, Cronbach alfa $=0,809$ za OdnosKakovMotiv, o,894 za Vodenje, 0819 za Pripadnost, o,869 za Kariera, o,77 I za ZadovoljNagrajevanje in 0,84I za Usposobljenost, spremenljivka vodenje se nanaša na delegiranje dela.

Legenda: e I ... e2 I = faktorji napake.

V nadaljevanju sledi preglednica 63, ki prikazuje standardizirane regresijske koeficiente in stopnje značilnosti za konstrukt organizacijska klima. 
Preglednica 63: Standardizirani regresijski koeficienti in stopnje značilnosti za konstrukt organizacijska klima

\begin{tabular}{|c|c|c|c|c|}
\hline Spremenljivka & Smer vpliva & Spremenljivka & $\begin{array}{l}\text { Standardiziran re- } \\
\text { gresijski koeficient }\end{array}$ & $\begin{array}{c}\text { Stopnja } \\
\text { značilnosti }(\mathbf{p})\end{array}$ \\
\hline odnosir & $<--$ & OdnosKakovMotiv & 0,814 & Fiksni \\
\hline odnosiz & $<--$ & OdnosKakovMotiv & 0,905 & $* *$ \\
\hline kakovosti & $<--$ & OdnosKakovMotiv & 0,497 & $* *$ \\
\hline kakovost2 & $<-$ & OdnosKakovMotiv & 0,447 & $* *$ \\
\hline kakovost3 & $<--$ & OdnosKakovMotiv & $0,55^{8}$ & $* *$ \\
\hline motiv2 & $<-$ & OdnosKakovMotiv & 0,506 & $* * *$ \\
\hline vodenje 4 & $<--$ & Vodenje & 0,930 & Fiksni \\
\hline vodenjez & $<--$ & Vodenje & 0,853 & $* *$ \\
\hline vodenjes & $<--$ & Vodenje & 0,815 & $* *$ \\
\hline pripadnost2 & $<-$ & Pripadnost & 0,863 & Fiksni \\
\hline pripadnost3 & $<--$ & Pripadnost & 0,876 & $* * *$ \\
\hline pripadnostı & $<--$ & Pripadnost & 0,620 & $* * *$ \\
\hline kariera2 & $<--$ & Kariera & 0,850 & Fiksni \\
\hline karierai & $<--$ & Kariera & 0,923 & $* *$ \\
\hline karieraz & $<--$ & Kariera & 0,717 & $* * *$ \\
\hline Zadovolj_zap9 & $<--$ & ZadovoljNagrajevanje & 0,875 & Fiksni \\
\hline Zadovolj_zapıo & $<--$ & ZadovoljNagrajevanje & 0,757 & $\cdots$ \\
\hline Zadovolj_zapı2 & $<--$ & ZadovoljNagrajevanje & 0,616 & $\ldots$ \\
\hline Nagrajevanjs & $<--$ & ZadovoljNagrajevanje & 0,510 & $* *$ \\
\hline usposob3 & $<-$ & Usposobljenost & 0,799 & Fiksni \\
\hline usposob4 & $<--$ & Usposobljenost & 0,919 & $* * *$ \\
\hline
\end{tabular}

Legenda: ${ }^{* * *}$ - p (stopnja značilnosti) je < o,oo I, fiksni - stopnje značilnosti ne preverjamo, saj je v merskem delu strukturnega modela ena od uteži merljivih spremenljivk vedno fiksirana na I.

Iz preglednice $6_{3}$ in diagrama konstrukta organizacijska klima s standardizirano rešitvijo (slika 7 ) izhaja, da je najmočnejša povezanost med opazovano spremenljivko vodenje 4 in latentno spremenljivko vodenje in znaša 0,930 . Najšibkejša je povezanost med opazovano spremenljivko kakovost2 in latentno spremenljivko OdnosKakovMotiv in znaša o,447. 


\section{Analiza konstrukta uspešnost poslovanja turističnih agencij}

Pri preučevanju konstrukta uspešnost poslovanja smo trditve iz anketnega vprašalnika v zvezi z oceno stopnje strinjanja s posameznimi trditvami iz določenega področja najprej kodirali v programu SPSS, kar smo potem uporabili pri nadaljnji analizi.

Kodiranje trditev z oceno stopenj strinjanj posamezne dimenzije konstrukta uspešnost poslovanja

Posamezne dimenzije konstrukta uspešnost poslovanja smo izbrali zato, ker smo v anketo poleg lastnikov/managerjev/vodij, ki imajo vpogled v določene dimenzije uspešnosti poslovanja, želeli vključiti tudi druge zaposlene $\mathrm{v}$ turističnih agencijah in njihovih poslovalnicah, ki pa so tudi seznanjeni s številnimi dimenzijami, s katerimi smo želeli preučevati uspešnost poslovanja.

Vse dimenzije konstrukta uspešnost poslovanja smo najprej kodirali. Vključene dimenzije smo izbrali tudi zato, ker smo želeli preučevati uspešnost poslovanja z različnimi spremenljivkami, ki smo jih vključili v anketni vprašalnik in nadaljnjo analizo, da bi s tem potrdili kar največji vpliv dejavnikov na uspešnost poslovanja.

Izvorna kodiranja dimenzij konstrukta uspešnost poslovanja $\mathrm{v}$ anketnem vprašalniku, kodiranja $\mathrm{v}$ SPSS in njihova uporaba $\mathrm{v}$ analizah ter trditve, ki se nanašajo na posamezne trditve, so navedeni v preglednici 64. 
Preglednica 64: Izvorna kodiranja dimenzij konstrukta UP v anketnem vprašalniku,

kodiranja v SPSS in njihova uporaba v analizah ter trditve, ki se nanašajo na posamezne trditve

Uspešnost poslovanja - dimenzije - trditve

\begin{tabular}{|c|c|c|}
\hline $\mathrm{Q}_{34 \mathrm{a}}$ & prihodki & Prihodki od prodaje \\
\hline $\mathrm{Q}_{34} \mathrm{~b}$ & dobicek & Dobiček \\
\hline $\mathrm{Q}_{34 \mathrm{C}}$ & dobickonosnostı & $\begin{array}{l}\text { Dobičkonosnost turistične agencije/poslovalnice v primerjavi s } \\
\text { konkurenčnimi turističnimi agencijami v obdobju } 20 \mathrm{II}-2 \mathrm{OI} 3 \text { glede } \\
\text { na obdobje } 2008-2010 \text {. }\end{array}$ \\
\hline $\mathrm{Q}_{34 \mathrm{~d}}$ & dobickonosnost2 & $\begin{array}{l}\text { Dobičkonosnost turistične agencije/poslovalnice v primerjavi s tur- } \\
\text { ističnimi agencijami, ki so na trgu enako število let in v enaki fazi raz- } \\
\text { voja, v obdobju } 2011-2013 \text { glede na obdobje } 2008-2010 \text {. }\end{array}$ \\
\hline $\mathrm{Q}_{34 \mathrm{e}}$ & rasti & Tržni delež na domačem trgu \\
\hline $\mathrm{Q}_{34} \mathrm{f}$ & rast2 & Tržni delež na tujem trgu \\
\hline $\mathrm{Q}_{34 \mathrm{~g}}$ & zaposleni & Število zaposlenih \\
\hline $\mathrm{Q}_{34} \mathrm{~h}$ & ROI & ROI \\
\hline $\mathrm{Q}_{34} \mathrm{i}$ & $\mathrm{ROA}$ & $\mathrm{ROA}$ \\
\hline $\mathrm{Q}_{34 \mathrm{j}}$ & $\mathrm{ROE}$ & $\mathrm{ROE}$ \\
\hline
\end{tabular}

\section{Eksplorativna faktorska analiza za konstrukt uspešnost poslovanja}

Namen izvedbe eksplorativne faktorske analize je bil odkriti latentno strukturo relativno obsežnega niza dimenzij s področja uspešnosti poslovanja turističnih agencij.

Iz preglednice 65 ugotovimo, da vrednost $\mathrm{KMO}$ znaša 0,662 in stopnja statistične značilnosti $\circ, 0 \circ 0$, korelacijska matrika pa ni enotska. Tako lahko torej zaključimo, da so naši podatki primerni za faktorsko analizo.

Sledi korak, namenjen analizi komunalitet posameznih spremenljivk, pri čemer smo izhajali iz postavljenega merila, da bomo izločili vse spremenljivke, ki imajo komunaliteto manjšo od o,3.

Preglednica 65: KMO in BT v okviru konstrukta uspešnost poslovanja

\begin{tabular}{lcc} 
KMO mera ustreznosti vzorca. & 0,662 \\
BT & Predviden Hi-kvadrat & 379,9 II \\
& df & 45 \\
& sig. & 0,000 \\
\hline
\end{tabular}


Preglednica 66 s komunalitetami prikazuje, da ima najvišjo ekstrahirano komunaliteto spremenljivka dobickonosnost2 (TA, ki so na trgu enako število let in v enaki fazi razvoja), ki znaša 0,999, in najnižjo spremenljivka zaposleni (zaposleni), ki znaša o, I 19 .

\section{Preglednica 66: Komunalitete spremenljivk konstrukta uspešnost poslovanja}

$\begin{array}{lcc}\text { Spremenljivke } & \text { Začetne } & \text { Končne } \\ \text { Prihodki od prodaje } & 0,396 & 0,455 \\ \text { Dobicek } & 0,388 & 0,412 \\ \text { dobickonosnostı } & 0,545 & 0,511 \\ \text { dobickonosnost2 } & 0,568 & 0,999 \\ \text { rastı } & 0,501 & 0,663 \\ \text { rast2 } & 0,340 & 0,317 \\ \text { zaposleni } & 0,176 & 0,119 \\ \text { ROI } & 0,569 & 0,572 \\ \text { ROA } & 0,711 & 0,930 \\ \text { ROE } & 0,575 & 0,609\end{array}$

Metoda ekstrakcije: metoda največje verjetnosti (angl. Maximum Likelihood). Med

ponovitvami so se pojavile ena ali več komunalitet z oceno večjo od I.

Iz preglednice 67 , ki prikazuje lastne vrednosti in skupne pojasnjene variance izločenih faktorjev za konstrukt uspešnost poslovanja, ugotovimo, da znaša vrednost pojasnjene variance $55,87 \%$, pri čemer so se oblikovali trije faktorji, kar nam prikazuje tudi kolenski diagram za konstrukt uspešnost poslovanja (slika 8).

Faktorji s pripadajočimi dejavniki konstrukta uspešnost poslovanja:

- Prvi faktor smo poimenovali donosnost, pripadajo pa mu naslednji dejavniki konstrukta uspešnost poslovanja: ROA, ROE in ROI.

- Drugi faktor smo poimenovali rast, pripadajo pa mu naslednji dejavniki konstrukta uspešnost poslovanja: rastı, prihodki, dobicek, rast2 in zaposleni.

- Tretji faktor smo poimenovali dobičkonosnost TA, pripadata pa mu naslednja dejavnika konstrukta uspešnost poslovanja: dobickonosnost2 in dobickonosnost I. 


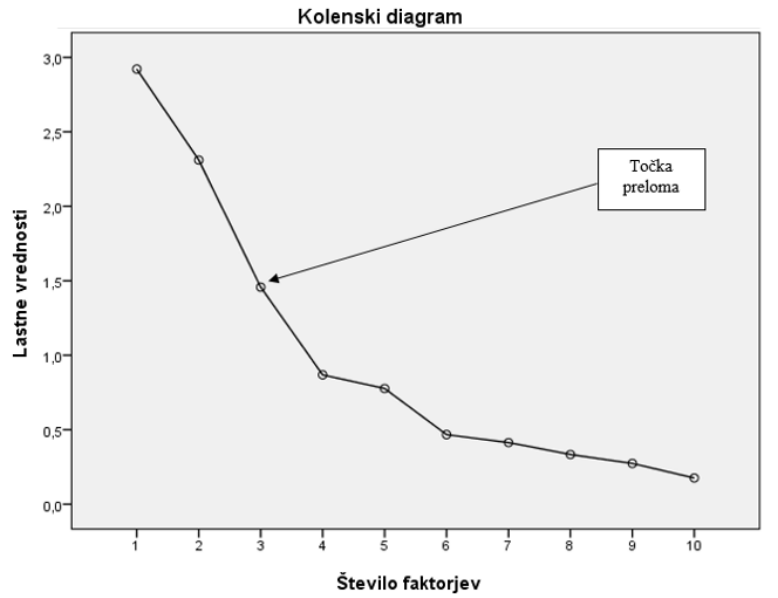

160

Slika 8: Kolenski diagram lastnih vrednosti za konstrukt uspešnost poslovanja in faktorji s pripadajočimi dejavniki konstrukta uspešnost poslovanja

Preglednica 67: Lastne vrednosti in skupne pojasnjene variance izločenih faktorjev za konstrukt uspešnost poslovanja

\begin{tabular}{|c|c|c|c|c|c|c|c|}
\hline \multirow{2}{*}{ Faktor } & \multicolumn{3}{|c|}{ Začetne lastne vrednosti } & \multicolumn{3}{|c|}{ Ekstrahirana vsota kvadratov uteži } & \multirow{2}{*}{$\begin{array}{c}\begin{array}{c}\text { Rotirana } \\
\text { vsota kvadra } \\
\text { tov uteži }\end{array} \\
\text { Skupaj }\end{array}$} \\
\hline & Skupaj & $\begin{array}{c}\text { Delež } \\
\text { variance }\end{array}$ & $\begin{array}{c}\text { Kumulativni } \\
\text { delež }\end{array}$ & Skupaj & $\begin{array}{c}\text { Delež } \\
\text { variance }\end{array}$ & $\begin{array}{c}\text { Kumulativni } \\
\text { delež }\end{array}$ & \\
\hline I & 2,907 & 29,074 & 29,074 & 1,750 & 17,496 & 17,496 & 2,157 \\
\hline 2 & 2,309 & 23,091 & 52,164 & 2,213 & 22,127 & 39,623 & 2,130 \\
\hline 3 & 1,456 & 14,559 & 66,724 & 1,625 & 16,247 & 55,870 & I,808 \\
\hline 4 & 0,873 & 8,726 & 75,450 & & & & \\
\hline 5 & 0,778 & 7,784 & 83,234 & & & & \\
\hline 6 & 0,468 & 4,675 & 87,909 & & & & \\
\hline 7 & 0,415 & 4,147 & 92,056 & & & & \\
\hline 8 & 0,344 & 3,436 & 95,492 & & & & \\
\hline 9 & 0,274 & 2,744 & 98,236 & & & & \\
\hline IO & 0,176 & 1,764 & 100,000 & & & & \\
\hline
\end{tabular}

Metoda ekstrakcije: metoda največjega verjetja (angl. Maximum Likelihood). Če so faktorji povezani, vsota kvadratov uteži ne more biti dodana za namen pridobitve skupne variance. 
Izvedena rotirana faktorska matrika v preglednici 68 za konstrukt uspešnost poslovanja nam prikazuje, da se spremenljivke, ki smo jih rotirali, enakomerno porazdelijo med faktorje in imajo večje uteži le pri treh faktorjih. Na podlagi tega smo ohranili vse spremenljivke.

Preglednica 68: Rotirana faktorska matrika za konstrukt uspešnost poslovanja

\begin{tabular}{lccc} 
& & Faktor & 3 \\
\cline { 2 - 4 } Spremenljivke & $\mathrm{I}$ & 2 & \\
ROA & 0,952 & & \\
ROE & 0,782 & & \\
ROI & 0,761 & 0,816 & \\
rast1 & & 0,684 & \\
Prihodkiod prodaje & & 0,562 & 1,015 \\
Dobicek & & 0,548 & 0,697 \\
rast2 & 0,355 & \\
Zaposleni & & & \\
dobickonosnost2 & & & \\
dobickonosnostı & & & \\
\hline
\end{tabular}

Metoda ekstrakcije: metoda največjega verjetja (angl. Maximum Likelihood); metoda rotacije: Promax with Kaiser Normalization. Rotacija konvergirana v štirih iteracijah.

Sledi preglednica $69 \mathrm{~s}$ prikazom matrike korelacij med faktorji konstrukta uspešnost poslovanja, s pomočjo katere ugotovimo, ali so faktorji po rotaciji ostali neodvisni.

Preglednica 69: Korelacije med faktorji konstrukta uspešnost poslovanja

\begin{tabular}{cccc} 
Faktor & \multicolumn{1}{c}{2} & \\
1 & 1,000 & 0,142 & $-0,027$ \\
2 & 0,142 & 1,000 & 0,347 \\
3 & $-0,027$ & 0,347 & 1,000
\end{tabular}

Metoda ekstrakcije: metoda največjega verjetja (angl. Maximum Likelihood); metoda rotacije: Promax with Kaiser Normalization.

Najnižja vrednost korelacije je $-0,027$ in najvišja vrednost korelacije 0,347 , kar pomeni, da so korelacije ustrezne. 


\section{Konfirmativna faktorska analiza za konstrukt uspešnost poslovanja}

Namen izvedbe konfirmativne faktorske analize je bil potrditi (konfirmirati) obstoj specifične in vnaprej predvidene faktorske strukture na področju konstrukta uspešnost poslovanja.

Tudi tu smo se naslanjali na rezultate eksplorativne faktorske analize, ki so pokazali, da je konstrukt uspešnost poslovanja sestavljen iz naslednjih dimenzij: rast, donosnost in dobičkonosnost TA.

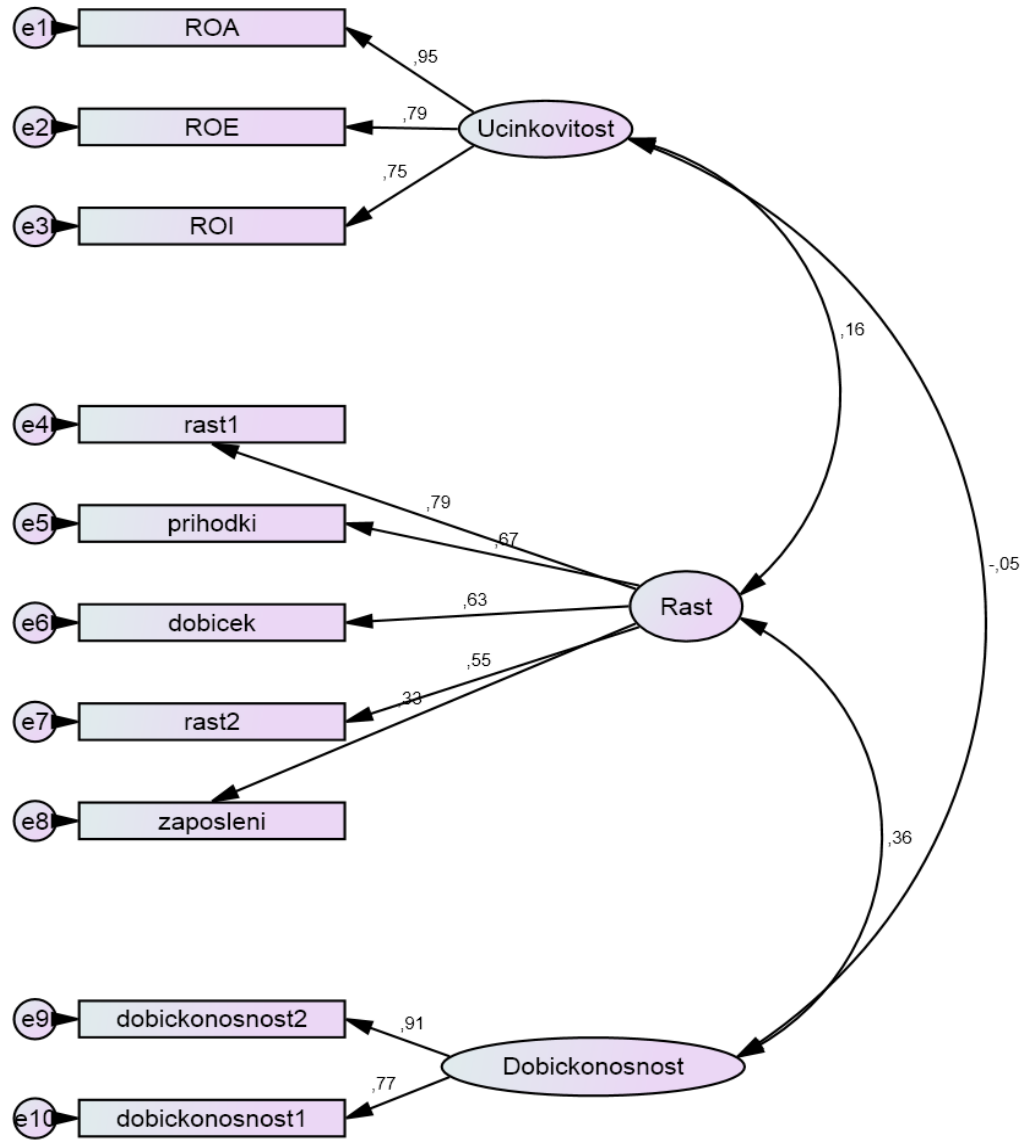

Slika 9: Diagram konstrukta uspešnost poslovanja s standardizirano rešitvijo

Hi-kvadrat $=47,406, \mathrm{df}=32, \mathrm{p}=0,039$

Opombe: $\mathrm{CFI}=0,956, \mathrm{NFI}=0,880, \mathrm{RFI}=0,832, \mathrm{RMSEA}=0,068$, Cronbach alfa $=0,864 \mathrm{za}$ Ucinkovitost, 0,717 za Rast in 0,826 za Dobickonosnost.

Legenda: Ucinkovitost $=$ Donosnost $(\mathrm{ROA}, \mathrm{ROE}, \mathrm{ROI})$, Rast $=$ Rast, Dobickonosnost $=$ Dobičkonosnost TA, e I ... e I o = faktorji napake. 
Konstrukt uspešnost poslovanja je pokazal visoko zanesljivost, saj so vrednosti Cronbachevega koeficienta $\alpha=0,864$ za Donosnost, $\alpha=0,717$ za Rast in $\alpha=0,826$ za Dobickonosnost TA visoke, razen za Rast, kjer so nekoliko nižje, vendar tudi še zelo zanesljive.

Iz ponazoritve diagrama poti (slika 9) za konstrukt uspešnost poslovanj vidimo, da je model vseboval naslednje latentne spremenljivke: donosnost, rast in dobičkonosnost TA. V modelu je sodelovalo ro opazovanih spremenljivk, kar je razvidno na sliki 9. Povezanost med latentnimi in opazovanimi spremenljivkami je enosmerna, in sicer v smeri od latentnih k opazovanim.

Iz preglednice 70 in diagrama konstrukta uspešnost poslovanja (slika 9) izhaja, da je najmočnejša povezanost med opazovano spremenljivko Donosnost in latentno spremenljivko ROA, ki je znašala o,950. Najšibkejša povezanost pa je med opazovano spremenljivko Rast in latentno spremenljivko Zaposleni in znaša o,33 I.

Preglednica 7o: Standardizirani regresijski koeficienti in stopnje značilnosti za konstrukt uspešnost poslovanja

\begin{tabular}{|c|c|c|c|c|}
\hline Spremenljivka & $\begin{array}{l}\text { Smer } \\
\text { vpliva }\end{array}$ & Spremenljivka & $\begin{array}{l}\text { Standardiziran regresijs- } \\
\text { ki koeficient }\end{array}$ & Stopnja značilnosti (p) \\
\hline ROA & $<--$ & Donosnost & 0,950 & Fiksni \\
\hline ROE & $<--$ & Donosnost & 0,788 & $* * *$ \\
\hline ROI & $<--$ & Donosnost & 0,754 & $\cdots$ \\
\hline rastı & $<\cdots$ & Rast & 0,790 & \\
\hline Prihodki od prodaje & $<--$ & Rast & 0,673 & $* * *$ \\
\hline Dobicek & $<--$ & Rast & 0,633 & $* *$ \\
\hline rast2 & $<--$ & Rast & 0,552 & ${ }^{* *}$ \\
\hline Zaposleni & $<--$ & Rast & 0,331 & 0,003 \\
\hline dobickonosnost2 & $<--$ & Dobickonosnost TA & 0,913 & Fiksni \\
\hline dobickonosnosti & $<--$ & Dobickonosnost TA & 0,772 & $\cdots$ \\
\hline
\end{tabular}

Legenda: ${ }^{* *}-\mathrm{p}$ (stopnja značilnosti) je < 0,00 I, fiksni - stopnje značilnosti ne preverjamo, saj je v merskem delu strukturnega modela ena od uteži merljivih spremenljivk vedno

fiksirana na I.

Za konstrukt uspešnost poslovanja lahko tudi rečemo, da ima visoko konvergenco v smislu koeficientov, saj so standardizirani regresijski koeficienti vseh treh faktorjev pri skoraj vseh spremenljivkah dokaj visoki (preglednica 70 ) in statistično značilni $(\mathrm{p}<0,00 \mathrm{I})$. Navedeno pomeni, da lahko z veliko zanesljivostjo trdimo, da ti vplivi obstajajo tudi pri celotni populaciji, ki je predstavljala naš vzorec. 
Vrednost RMSEA znaša 0,068 , kar pomeni, da je po tem merilu prilagajanje modela dobro. Ostali indeksi (CFI $=0,956$, NFI $=0,880$, $\mathrm{RFI}=0,832)$ so razmeroma visoki, kar kaže na dobro prilagajanje. Tako lahko ocenjujemo, da je prilagajanje modela konstrukta uspešnost poslovanja dobro (slika 9). 


\section{Preverjanje hipotez}

Pri preverjanju hipotez smo izvedli statistični analizi, imenovani korelacijska analiza za odkrivanje povezanosti in multipla linearna regresija, za kateri Kropivnik idr. (2006, 80) menijo, da sta namenjeni raziskovanju linearnih vzročnih povezanosti med eno odvisno spremenljivko in eno ali več neodvisnimi spremenljivkami. $Z$ njima ugotavljamo statistično značilnost in moč povezanosti ter napovedujemo vrednosti odvisne spremenljivke. Vpliv vsake od neodvisnih spremenljivk je ocenjen tako, da ni odvisen od medsebojnih vplivov neodvisnih spremenljivk. Vse korelacije, ki smo jih analizirali, so sestavni del vsake izmed dvanajstih podhipotez, $s$ katerimi smo preučevali tri hipoteze, vendar zaradi omejenega prostora $\mathrm{v}$ monografiji niso navedene.

\section{Preverjanje $\mathrm{H}_{\mathrm{r}}$ : Med človeškim kapitalom in organizacijsko klimov} turističnih agencijah obstaja pozitivna medsebojna povezava.

Preverjanje povezanosti med konstruktom človeški kapital in organizacijska klima smo tako kot pri ostalih hipotezah izvedli s korelacijsko in regresijsko analizo. Model preverjanja obsega latentne spremenljivke obeh konstruktov, ki so bile pripravljene na podlagi izvedbe faktorske analize.

V preglednici 7I navajamo latentne spremenljivke konstruktov človeški kapital in organizacijska klima. Prve smo v posameznih podhipotezah hipoteze $\mathrm{H}_{\mathrm{r}}$ uporabili kot neodvisne spremenljivke in jih primerjali s posamezno odvisno spremenljivko konstrukta organizacijska klima. 
prenos znanja - nestimulativni (Prenos_A);

izobraževanje s področja trženja (Vrst_A);

izobraževanja s področja komuniciranja (Vrst_B);

notranji odnosi (OdnosKakovMotiv);

vodenje (delegiranje dela) (Vodenje);

uporaba znanja na lastnih izkušnjah (UporabaVrst);

pripadnost organizaciji (Pripadnost);

čas izobraževanja (CasaVrst);

razvoj kariere (Kariera);

prenos znanja - timski (Prenos_B);

shranjevanje znanja (Shranjev);

pridobivanje znanja (Pridobiv);

zadovoljstvo zaposlenih in nagrajevanje (ZadovoljNa-

grajevanj);

uporaba znanja (Uporaba).

strokovno usposabljanje in učenje (Usposobljenost).

Preverjanje hipoteze Hı tako obsega šest podhipotez, ki preverjajo povezanost konstrukta človeški kapital s posameznimi odvisnimi spremenljivkami konstrukta organizacijska klima.

Preverjanje podhipotez je izvedeno $\mathrm{v}$ dveh korakih. V prvem koraku s pomočjo korelacijske analize preverjamo jakost povezanosti med spremenljivkami konstrukta človeški kapital in posamezno spremenljivko konstrukta organizacijska klima. Nato pa modele obravnavamo s pomočjo linearne regresijske analize ter ocenimo multipli regresijski model (multipli korelacijski koeficient, popravljeni determinacijski koeficient). Nazadnje ocenimo še vplivnost posameznih spremenljivk (dimenzij) človeškega kapitala na posamezne latentne spremenljivke (dimenzije) organizacijske klime.

Hra: Med človeškim kapitalom in notranjimi odnosi (OdnosKakovMotiv) kot sestavino organizacijske klime v turističnih agencijah obstaja pozitivna medsebojna povezava.

Pri preverjanju podhipoteze smo uporabili neodvisne spremenljivke konstrukta človeški kapital in odvisno spremenljivko notranji odnosi (OdnosKakovMotiv) kot sestavina organizacijske klime (preglednica $7 \mathrm{I})$.

Korelacije spremenljivk ČK so s spremenljivko notranji odnosi kot sestavina OK pozitivne v vseh primerih, razen pri spremenljivki Prenos_A, statistično značilne $(\mathrm{p}<0,028)$, vrednosti koeficientov pa so med 0,18 in $0,5 \mathrm{I}$.

Ocena multiplega regresijskega modela je prikazana v preglednici 72. 
Preglednica 72: Ocena regresijskega modela za človeški kapital in notranje odnose kot sestavino organizacijske klime

\begin{tabular}{lc}
\hline Povzetek modela & \\
\hline $\mathrm{R}$ & 0,609 \\
$\mathrm{R}^{2}$ & 0,371 \\
Popravljen $\mathrm{R}^{2}$ & 0,311 \\
\hline ANOVA & \\
\hline F & 6,163 \\
P & 0,000 \\
\hline
\end{tabular}

$\mathrm{Na}$ osnovi multiplega korelacijskega koeficienta $\mathrm{R}=0,609$ ocenjujemo, da je povezanost odvisne spremenljivke notranji odnosi kot sestavina organizacijske klime z neodvisnimi spremenljivkami človeškega kapitala zmerna in pozitivna. Popravljen determinacijski koeficient $\mathrm{R}^{2}=0,3 \mathrm{II}$ izkazuje, da lahko z vključenimi neodvisnimi spremenljivkami pojasnimo 3I,I \% variabilnosti odvisne spremenljivke notranji odnosi kot sestavina organizacijske klime.

Ob pregledu regresijskih koeficientov in rezultatov t-testov lahko iz preglednice 73 razberemo, da pri stopnji tveganja o,05 ostaja samo en statistično značilen regresijski koeficient, in sicer pri spremenljivki Uporaba $\left(\mathrm{X}_{\mathrm{r}}, \mathrm{b}=0,229, \mathrm{p}=0,00 \mathrm{I}\right)$.

$\mathrm{V}$ preglednici 73 so prikazani koeficienti regresijskega modela spremenljivk človeškega kapitala in spremenljivke notranji odnosi kot sestavina organizacijske klime.

\section{Preglednica 73: Koeficienti regresijskega modela spremenljivk človeškega kapitala in spremenljivke notranji odnosi kot sestavina organizacijske klime}

\begin{tabular}{lccc} 
Koeficienti & $\mathrm{b}$ & $\mathrm{t}$ & $\mathrm{P}$ \\
(Konstanta) & 2,633 & 8,123 & 0,000 \\
Prenos_A & $-0,053$ & $-1,251$ & 0,214 \\
Vrst_A & 0,034 & 0,759 & 0,450 \\
Vrst_B & $-0,015$ & $-0,322$ & 0,749 \\
UporabaVrst & 0,137 & 1,916 & 0,058 \\
CasaVrst & 0,092 & 1,409 & 0,162 \\
Prenos_B & 0,071 & 1,043 & 0,299 \\
Shranjev & $-0,072$ & $-1,393$ & 0,167 \\
Pridobiv & 0,027 & 0,612 & 0,542 \\
Uporaba & 0,229 & 3,547 & 0,001 \\
\hline
\end{tabular}


Hra: Med človeskim kapitalom in notranjimi odnosi kot sestavino organizacijske klime obstaja pozitivna medsebojna povezava.

Sklep: Povezanost med človeškim kapitalom in spremenljivko notranji odnosi kot sestavina organizacijske klime je pozitivna in pri vseh spremenljivkah, razen pri eni, tudi statistično značilna. Vendar pa je regresijska analiza pokazala, da vpliv temelji na eni sami spremenljivki, to je uporaba. Ugotovili smo torej, da le ta spremenljivka izmed vseh spremenljivk človeškega kapitala statistično značilno vpliva na odvisno spremenljivko notranji odnosi kot sestavina organizacijske klime, zato labko to podhipotezo delno potrdimo.

HIb: Med človeškim kapitalom in vodenjem (delegiranjem dela) (Vodenje) kot sestavino organizacijske klime v turističnih agencijah obstaja pozitivna medsebojna povezava.

Pri preverjanju podhipoteze smo uporabili neodvisne spremenljivke konstrukta človeški kapital in odvisno spremenljivko vodenje (delegiranje dela) (Vodenje) kot sestavina organizacijske klime (preglednica 7I).

Korelacije spremenljivk ČK so s spremenljivko vodenje (delegiranje dela) kot sestavina OK pozitivne v vseh primerih, razen pri spremenljivki Vrst_A, statistično značilne $(\mathrm{p}<0,030)$, vrednosti koeficientov pa so med 0,18 in 0,57 .

Ocena multiplega regresijskega modela je prikazana v preglednici 74 .

Preglednica 74: Ocena regresijskega modela za človeški kapital in vodenje (delegiranje dela)

kot sestavino organizacijske klime

\begin{tabular}{lc}
\hline Povzetek modela & \\
\hline $\mathrm{R}$ & 0,703 \\
$\mathrm{R}^{2}$ & 0,494 \\
Popravljen R & 0,446 \\
\hline ANOVA & \\
\hline F & 10,208 \\
P & 0,000 \\
\hline
\end{tabular}

$\mathrm{Na}$ osnovi multiplega korelacijskega koeficienta $\mathrm{R}=0,703$ ocenjujemo, da je povezanost odvisne spremenljivke vodenje (delegiranje dela) kot sestavina organizacijske klime z neodvisnimi spremenljivkami človeškega kapitala močna in pozitivna. Popravljen determinacijski koeficient 
$\mathrm{R}^{2}=0,446$ izkazuje, da lahko z vključenimi neodvisnimi spremenljivkami pojasnimo $44,6 \%$ variabilnosti odvisne spremenljivke vodenje (delegiranje dela) kot sestavina organizacijske klime.

$\mathrm{Ob}$ pregledu regresijskih koeficientov in rezultatov t-testov lahko iz preglednice 75 razberemo, da so pri stopnji tveganja 0,05 značilni regresijski koeficienti pri spremenljivkah: Vrst_A $\left(X_{1}, b=-0,164, p=0,012\right)$, Vrst_B $\left(X_{2}, b=0,191, p=0,005\right)$, UporabaVrst $\left(X_{3}, b=0,377, p=0,000\right)$, CasaVrst $\left(X_{4}, b=-0,227, p=0,016\right)$, Prenos_B $\left(X_{5}, b=0,204, p=0,037\right)$ in Uporaba $\left(\mathrm{X}_{6}, \mathrm{~b}=0,3 \mathrm{I} 3, \mathrm{p}=0,00 \mathrm{I}\right)$.

V preglednici 75 so prikazani regresijski koeficienti spremenljivk človeškega kapitala in spremenljivke vodenje (delegiranje dela) kot sestavina organizacijske klime.

Preglednica 75: Koeficienti regresijskega modela spremenljivk človeškega kapitala in

spremenljivke vodenje (delegiranje dela) kot sestavina organizacijske klime

\begin{tabular}{lccc} 
Koeficienti & $\mathrm{b}$ & $\mathrm{t}$ & $\mathrm{P}$ \\
\hline Konstanta) & $\mathrm{I}, 353$ & $2,94 \mathrm{1}$ & 0,004 \\
Prenos_A & 0,068 & $\mathrm{I}, \mathrm{122}$ & 0,265 \\
Vrst_A & $-0,164$ & $-2,561$ & $0,0 \mathrm{I} 2$ \\
Vrst_B & 0,191 & 2,870 & 0,005 \\
UporabaVrst & 0,377 & 3,706 & 0,000 \\
CasaVrst & $-0,227$ & $-2,453$ & 0,016 \\
Prenos_B & 0,204 & 2,113 & 0,037 \\
Shranjev & 0,008 & 0,105 & 0,917 \\
Pridobiv & $-0,050$ & $-0,803$ & 0,424 \\
Uporaba & 0,313 & 3,418 & 0,001 \\
\hline
\end{tabular}

HI b: Med človeškim kapitalom in vodenjem (delegiranjem dela) kotsestavino organizacijske klime $v$ turističnih agencijah obstaja pozitivna medsebojna povezava.

Sklep: Povezanost med človeškim kapitalom in spremenljivko vodenje (delegiranje dela) kot sestavina organizacijske klime je pozitivna in pri vseh spremenljivkah, razen pri eni, tudi statistično značilna. Regresijska analiza je pokazala, da od devetih spremenljivk človeškega kapitala šest spremenljivk statistično značilno vpliva na vodenje (delegiranje dela) kot sestavino organizacijske klime, tri pa ne. Ker sta dva izmed šestih statistično značilnih koeficientov negativna, moramo podhipotezo zavrniti. Ugotovili smo torej, da spremenljivke človeškega kapitala izobraževanje 
s področja komuniciranja, uporaba znanja pri lastnih izkušnjah, prenos znanja in uporaba znanja statistično pozitivno značilno vplivajo na odvisno spremenljivko vodenje (delegiranje dela) kot sestavina organizacijske klime, izobraževanje na področju trženja ter čas in vrsta izobraževanja pa statistično negativno značilno vplivajo na odvisno spremenljivko vodenje (delegiranje dela) kot sestavina organizacijske klime. Zaradi negativnih uplivov moramo to podhipotezo zavrniti.

Hic: Med cloveskkim kapitalom in pripadnostjo organizaciji (Pripadnost) kot sestavino organizacijske klime v turističnih agencijah obstaja pozitivna medsebojna povezava.

Pri preverjanju podhipoteze smo uporabili neodvisne spremenljivke konstrukta človeški kapital in odvisno spremenljivko pripadnost organizaciji (Pripadnost) kot sestavina organizacijske klime (preglednica 7I).

Korelacije spremenljivk ČK so s spremenljivko pripadnost organizaciji kot sestavina OK pozitivne v vseh primerih, razen pri spremenljivkah Prenos_A in Pridobiv, statistično značilne $(\mathrm{p}<0,013)$, vrednosti koeficientov so med $0,2 \mathrm{I}$ in 0,46 .

Ocena multiplega regresijskega modela je prikazana v preglednici 76 .

Preglednica 76 : Ocena regresijskega modela za človeški kapital in pripadnost organizaciji kot sestavino organizacijske klime

\begin{tabular}{lc}
\hline Povzetek modela & \\
\hline $\mathrm{R}$ & 0,545 \\
$\mathrm{R}^{2}$ & 0,297 \\
Popravljen R & 0,230 \\
\hline ANOVA & \\
\hline F & 4,414 \\
P & 0,000 \\
\hline
\end{tabular}

$\mathrm{Na}$ osnovi multiplega korelacijskega koeficienta $\mathrm{R}=0,545$ ocenjujemo, da je povezanost odvisne spremenljivke pripadnost organizaciji kot sestavina organizacijske klime z neodvisnimi spremenljivkami človeškega kapitala zmerna in pozitivna. Popravljen determinacijski koeficient $\mathrm{R}^{2}=0,230$ izkazuje, da lahko $\mathrm{z}$ vključenimi neodvisnimi spremenljivkami pojasnimo $23 \%$ variabilnosti odvisne spremenljivke pripadnost organizaciji kot sestavina organizacijske klime. 
Ob pregledu regresijskih koeficientov in rezultatov t-testov lahko iz preglednice 77 razberemo, da pri stopnji tveganja 0,05 ostaja samo en statistično značilen regresijski koeficient, in sicer pri spremenljivki Upora$\mathrm{baVrst}\left(\mathrm{X}_{\mathrm{r}}, \mathrm{b}=0,369, \mathrm{p}=0,000\right)$.

$\mathrm{V}$ preglednici 77 so prikazani koeficienti regresijskega modela spremenljivk človeškega kapitala in spremenljivke pripadnost organizaciji kot sestavina organizacijske klime.

\section{Preglednica 77: Koeficienti regresijskega modela spremenljivk človeškega kapitala in}

spremenljivke pripadnost organizaciji kot sestavina organizacijske klime

\begin{tabular}{lccc} 
Kocficienti & $\mathrm{b}$ & $\mathrm{t}$ & $\mathrm{P}$ \\
\hline Konstanta) & 2,347 & 5,175 & 0,000 \\
Prenos_A & $-0,051$ & $-0,852$ & 0,396 \\
Vrst_A & 0,046 & 0,732 & 0,466 \\
Vrst_B & 0,070 & 1,071 & 0,287 \\
UporabaVrst & 0,369 & 3,670 & 0,000 \\
CasaVrst & $-0,067$ & $-0,735$ & 0,464 \\
Prenos_B & 0,011 & 0,113 & 0,910 \\
Shranjev & 0,091 & 1,262 & 0,210 \\
Pridobiv & $-0,097$ & $-1,597$ & 0,114 \\
Uporaba & 0,124 & 1,370 & 0,174 \\
\hline
\end{tabular}

HIc: Med človeškim kapitalom in pripadnostjo organizaciji kot sestavino organizacijske klime $v$ turističnih agencijah obstaja pozitivna medsebojnapovezava.

Sklep: Povezanost med človeškim kapitalom in spremenljivko pripadnost organizaciji kot sestavina organizacijske klime je pozitivna in pri vseh spremenljivkah, razen pri dveh, tudi statistično značilna. Vendar pa je regresijska analiza pokazala, da vpliv temelji na eni sami spremenljivki, to je spremenljivka UporabaVrst. Ugotovili smo torej, da izmed vseh neodvisnih spremenljivk le spremenljivka uporaba znanja pri lastnih izkušnjah statistično značilno vpliva na odvisno spremenljivko pripadnost organizaciji kot sestavina organizacijske klime, zato lahko to podhipotezo le delno potrdimo. 
HIč: Med človeškim kapitalom in razvojem kariere (Kariera) kot sestavino organizacijske klime $v$ turističnih agencijah obstaja pozitivna medsebojna povezava.

Pri preverjanju podhipoteze smo uporabili neodvisne spremenljivke konstrukta človeški kapital in odvisno spremenljivko razvoj kariere (Kariera) kot sestavina organizacijske klime (preglednica $7 \mathrm{I}$ ).

Korelacije spremenljivk ČK so s spremenljivko razvoj kariere kot sestavina OK pozitivne v vseh primerih, razen pri spremenljivki Pridobiv, statistično značilne $(\mathrm{p}<0,004)$, vrednosti koeficientov pa so med 0,260 in 0,474 .

Ocena multiplega regresijskega modela je prikazana v preglednici 78 .

Preglednica 78: Ocena regresijskega modela za človeški kapital in razvoj kariere kot sestavino organizacijske klime

\begin{tabular}{lc}
\hline Povzetek modela & \\
\hline $\mathrm{R}$ & 0,550 \\
$\mathrm{R}^{2}$ & 0,302 \\
Popravljen $\mathrm{R}^{2}$ & 0,235 \\
\hline ANOVA & \\
\hline F & 4,522 \\
P & 0,000 \\
\hline
\end{tabular}

$\mathrm{Na}$ osnovi multiplega korelacijskega koeficienta $\mathrm{R}=0,550$ ocenjujemo, da je povezanost odvisne spremenljivke razvoj kariere kot sestavina organizacijske klime z neodvisnimi spremenljivkami človeškega kapitala zmerna in pozitivna. Popravljen determinacijski koeficient $\mathrm{R}^{2}=0,235 \mathrm{iz}-$ kazuje, da lahko z vključenimi neodvisnimi spremenljivkami pojasnimo $23,5 \%$ variabilnosti odvisne spremenljivke razvoj kariere kot sestavina organizacijske klime.

Ob pregledu regresijskih koeficientov in rezultatov t-testov lahko iz preglednice 79 razberemo, da pri stopnji tveganja o,05 ostaja samo en statistično značilen regresijski koeficient, in sicer pri spremenljivki Uporaba $\left(\mathrm{X}_{\mathrm{r}}, \mathrm{b}=0,326, \mathrm{p}=0,0 \mathrm{12}\right)$.

$\mathrm{V}$ preglednici 79 so prikazani koeficienti regresijskega modela spremenljivk človeškega kapitala in spremenljivke razvoj kariere kot sestavina organizacijske klime. 
Preglednica 79: Koeficienti regresijskega modela spremenljivk človeškega kapitala in spremenljivke razvoj kariere kot sestavina organizacijske klime

\begin{tabular}{lccc} 
Koeficienti & $\mathbf{b}$ & $\mathbf{t}$ & $\mathbf{P}$ \\
\hline Konstanta) & $\mathrm{I}, 483$ & 2,328 & 0,022 \\
\hline Prenos_A & 0,018 & 0,217 & 0,829 \\
\hline Vrst_A & 0,154 & 1,733 & 0,086 \\
\hline Vrst_B & 0,013 & 0,146 & 0,884 \\
\hline UporabaVrst & 0,148 & 1,047 & 0,298 \\
\hline CasaVrst & 0,010 & 0,077 & 0,939 \\
\hline Prenos_B & 0,035 & 0,262 & 0,794 \\
\hline Shranjev & 0,103 & 1,010 & 0,315 \\
\hline Pridobiv & $-0,157$ & $-1,839$ & 0,069 \\
\hline Uporaba & 0,326 & 2,571 & 0,012 \\
\hline
\end{tabular}

HIč: Med človeškim kapitalom in razvojem kariere kot sestavino organizacijske klime $v$ turističnih agencijah obstaja pozitivna medsebojna povezava.

Sklep: Povezanost med človeškim kapitalom in spremenljivko kariera kot sestavina organizacijske klime je pozitivna in pri vseh spremenljivkah, razen pri eni, tudi statistično značilna. Vendar pa je regresijska analiza pokazala, da vpliv temelji na eni sami spremenljivki, to je spremenljivka uporaba. Ugotovili smo torej, da le ta spremenljivka uporaba znanja statistično značilno vpliva na odvisno spremenljivko kariera kot sestavina organizacijske klime, zato labko to podhipotezo le delno potrdimo.

HId: Med človeškim kapitalom ter zadovoljstvom zaposlenih in nagrajevanjem (ZadovoljNagrajevanj) kot sestavino organizacijske klime v turističnih agencijah obstaja pozitivna medsebojna povezava.

Pri preverjanju podhipoteze smo uporabili neodvisne spremenljivke konstrukta človeški kapital (preglednica 7I) in odvisno spremenljivko zadovoljstvo zaposlenih in nagrajevanje (ZadovoljNagrajevanj) kot sestavina organizacijske klime.

Korelacije spremenljivk ČK so s spremenljivko zadovoljstvo zaposlenih in nagrajevanje kot sestavina $\mathrm{OK}$ pozitivne in $\mathrm{v}$ vseh primerih sta- 
tistično značilne ( $\mathrm{p}<0,015)$, vrednosti koeficientov pa so med 0,213 in 0,482 .

Ocena multiplega regresijskega modela je prikazana v preglednici 80 .

Preglednica 80: Ocena regresijskega modela za človeški kapital ter zadovoljstvo zaposlenih in nagrajevanje kot sestavino organizacijske klime

\begin{tabular}{lc}
\hline Povzetek modela & \\
\hline $\mathrm{R}$ & 0,619 \\
$\mathrm{R}^{2}$ & 0,383 \\
Popravljen R & 0,324 \\
\hline ANOVA & \\
\hline F & 6,494 \\
$\mathrm{P}$ & 0,000 \\
\hline
\end{tabular}

Na osnovi multiplega korelacijskega koeficienta $\mathrm{R}=0,619$ ocenjujemo, da je povezanost odvisne spremenljivke zadovoljstvo zaposlenih in nagrajevanje kot sestavina organizacijske klime z neodvisnimi spremenljivkami človeškega kapitala zmerna in pozitivna. Popravljen determinacijski koeficient $\mathrm{R}^{2}=0,324$ izkazuje, da lahko z vključenimi neodvisnimi spremenljivkami pojasnimo 32,4 \% variabilnosti odvisne spremenljivke zadovoljstvo zaposlenih in nagrajevanje kot sestavina organizacijske klime.

Ob pregledu regresijskih koeficientov in rezultatov t-testov lahko iz preglednice 8I razberemo, da so pri stopnji tveganja o,05 statistično značilni regresijski koeficienti pri spremenljivkah: Vrst_B $\left(\mathrm{X}_{\mathrm{r}}, \mathrm{b}=0,2 \mathrm{I}\right.$, $\mathrm{p}=0,006)$, UporabaVrst $\left(\mathrm{X}_{2}, \mathrm{~b}=0,245, \mathrm{p}=0,038\right)$ in Shranjev $\left(\mathrm{X}_{3}\right.$, $\mathrm{b}=0,169, \mathrm{p}=0,048)$.

V preglednici 8I so prikazani koeficienti regresijskega modela spremenljivk človeškega kapitala ter spremenljivke zadovoljstvo zaposlenih in nagrajevanje kot sestavina organizacijske klime.

HId: Med človeškim kapitalom ter zadovoljstvom zaposlenih in nagrajevanjem kot sestavino organizacijske klime $v$ turističnih agencijah obstaja pozitivna medsebojna povezava.

Sklep: Povezanost med človeškim kapitalom ter spremenljivko zadovoljstvo zaposlenih in nagrajevanje kot sestavina organizacijske klime je pozitivna in pri vseh spremenljivkah tudi statistično značilna. Vendar pa je regresijska analiza pokazala, da vpliv temelji le na treh spremenljivkah od devetih. Ugotovili smo torej, da le tri spremenljivke človeškega kapitala, izobraževanje s področja komuniciranja, uporaba znanja pri lastnih iz- 
kušnjah in shranjevanje znanja, statistično značilno vplivajo na odvisno spremenljivko zadovoljstvo zaposlenih in nagrajevanje kot sestavina organizacijske klime, zato labko to podhipotezo le delno potrdimo.

Preglednica 81: Koeficienti regresijskega modela spremenljivk človeškega kapitala ter spremenljivke zadovoljstvo zaposlenih in nagrajevanje kot sestavina organizacijske klime

\begin{tabular}{lccc} 
Koeficienti & $\mathrm{b}$ & $\mathrm{t}$ & $\mathrm{P}$ \\
\hline (Konstanta) & 0,944 & $\mathrm{1}, 796$ & 0,076 \\
Prenos_A & $-0,018$ & $-0,257$ & 0,797 \\
Vrst_A & 0,016 & 0,220 & 0,826 \\
Vrst_B & 0,212 & 2,790 & 0,006 \\
UporabaVrst & 0,245 & 2,104 & 0,038 \\
CasaVrst & $-0,003$ & $-0,027$ & 0,979 \\
Prenos_B & 0,155 & 1,402 & 0,164 \\
Shranjev & 0,169 & 2,007 & 0,048 \\
Pridobiv & $-0,033$ & $-0,470$ & 0,640 \\
Uporaba & 0,018 & 0,176 & 0,861 \\
\hline
\end{tabular}

Hie: Med človeškim kapitalom ter strokovno usposobljenostjo in učenjem (Usposobljenost) kot sestavino organizacijske klime v turističnih agencijah obstaja pozitivna medsebojna povezava.

Pri preverjanju podhipoteze smo uporabili neodvisne spremenljivke konstrukta človeški kapital in odvisno spremenljivko strokovna usposobljenost in učenje (Usposobljenost) kot sestavina organizacijske klime (preglednica $7 \mathrm{I})$.

Korelacije spremenljivk ČK so s spremenljivko strokovna usposobljenost in učenje kot sestavina OK pozitivne in $\mathrm{v}$ vseh primerih statistično značilne $(\mathrm{p}<0,007)$, vrednosti koeficientov pa so med $0,24 \mathrm{I}$ in 0,492 .

Ocena multiplega regresijskega modela je prikazana v preglednici 82 .

$\mathrm{Na}$ osnovi multiplega korelacijskega koeficienta $\mathrm{R}=0,632$ ocenjujemo, da je povezanost odvisne spremenljivke strokovna usposobljenost in učenje kot sestavina organizacijske klime $\mathrm{z}$ neodvisnimi spremenljivkami človeškega kapitala zmerna in pozitivna. Popravljen determinacijski koeficient $\mathrm{R}^{2}=0,4 \mathrm{I}$ s izkazuje, da lahko $\mathrm{z}$ vključenimi neodvisnimi spremenljivkami pojasnimo 4I,5\% variabilnosti odvisne spremenljivke strokovna usposobljenost in učenje kot sestavina organizacijske klime. 
Preglednica 82: Ocena regresijskega modela za človeški kapital ter strokovno

usposobljenost in učenje kot sestavino organizacijske klime

\begin{tabular}{lc}
\hline Povzetek modela & \\
\hline $\mathrm{R}$ & 0,632 \\
$\mathrm{R}^{2}$ & 0,465 \\
Popravljen $\mathrm{R}^{2}$ & 0,415 \\
\hline ANOVA & \\
\hline F & 9,107 \\
P & 0,000 \\
\hline
\end{tabular}

Ob pregledu regresijskih koeficientov in rezultatov t-testov lahko iz preglednice 83 razberemo, da so pri stopnji tveganja o,o5 statistično značilni regresijski koeficienti pri spremenljivkah: Vrst_B (XI, b = o,175, $\mathrm{p}=0,015)$, UporabaVrst $\left(\mathrm{X}_{2}, \mathrm{~b}=0,424, \mathrm{p}=0,000\right)$ in CasaVrst $\left(\mathrm{X}_{3}\right.$, $\mathrm{b}=0,28 \mathrm{I}, \mathrm{p}=0,005)$.

$\mathrm{V}$ preglednici 83 so prikazani koeficienti regresijskega modela spremenljivk človeškega kapitala in spremenljivke strokovna usposobljenost ter učenje kot sestavina organizacijske klime.

Preglednica 83: Koeficienti regresijskega modela spremenljivk človeškega kapitala ter spremenljivke strokovna usposobljenost in učenje kot sestavina organizacijske klime

\begin{tabular}{lccl} 
Koeficienti & $\mathrm{b}$ & $\mathrm{t}$ & $\mathrm{P}$ \\
\hline Konstanta) & 0,848 & $\mathrm{I}, 735$ & 0,086 \\
\hline Prenos_A & 0,026 & 0,409 & 0,684 \\
\hline Vrst_A & $-0,057$ & $-0,837$ & 0,405 \\
\hline Vrst_B & 0,175 & 2,485 & 0,015 \\
\hline UporabaVrst & 0,424 & 3,923 & 0,000 \\
\hline CasaVrst & $0,28 \mathrm{I}$ & 2,851 & 0,005 \\
\hline Prenos_B & $-0,109$ & $-1,061$ & 0,292 \\
\hline Shranjev & $-0,051$ & $-0,653$ & 0,515 \\
\hline Pridobiv & 0,004 & 0,063 & 0,950 \\
\hline Uporaba & 0,134 & 1,375 & 0,172 \\
\hline
\end{tabular}

Hre: Med človeškim kapitalom ter strokovno usposobljenostjo in učenjem kot sestavino organizacijske klime v turističnih agencijah obstaja pozitivna medsebojna povezava.

Sklep: Povezanost med človeškim kapitalom ter spremenljivko strokovna usposobljenostjo in učenje kot sestavina organizacijske klime je po- 
zitivna in pri vseh spremenljivkah tudi statistično značilna. Vendar pa je regresijska analiza pokazala, da vpliv temelji le na treh spremenljivkah od devetih. Ugotovili smo torej, da le spremenljivke človeškega kapitala, izobraževanje s področja komuniciranja, uporaba znanja pri lastnih izkušnjah ter čas in vrsta izobraževanja, statistično značilno vplivajo na odvisno spremenljivko strokovna usposobljenost in učenje kot sestavina organizacijske klime, zato lahko to podhipotezo le delno potrdimo.

$\mathrm{V}$ preglednici 84 je povzetek preverjanja podhipotez, s katerimi smo preverjali $\mathrm{H}_{\mathrm{I}}$.

Preglednica 84: Povzetek preverjanja hipoteze $\mathrm{H}_{\mathrm{I}}$

\begin{tabular}{|c|c|c|c|}
\hline Povzetek preverjanja hipoteze $\mathrm{H}_{\mathrm{I}}$ & $\begin{array}{l}\text { Spremenljivke - statistično } \\
\text { značilen vpliv }\end{array}$ & Potrditev & Ugotovitev \\
\hline $\begin{array}{l}\text { HI } \\
\text { Med človeškim kapitalom in organizacijsko klimo } \\
\text { obstaja pozitivna medsebojna povezava. }\end{array}$ & & & $\begin{array}{c}\text { Delno } \\
\text { potrjena }\end{array}$ \\
\hline $\begin{array}{l}\text { Hıa } \\
\text { Med človeškim kapitalom in notranjimi odnosi kot } \\
\text { sestavino organizacijske klime obstaja pozitivna } \\
\text { medsebojna povezava. }\end{array}$ & Uporaba $(+)$ & Delno & \\
\hline $\begin{array}{l}\text { Hib } \\
\text { Med človeškim kapitalom in vodenjem (delegiran- } \\
\text { jem dela) kot sestavino organizacijske klime obstaja } \\
\text { pozitivna medsebojna povezava. }\end{array}$ & $\begin{array}{c}\text { Vrst_A (-) } \\
\text { Vrst_B (+) } \\
\text { UporabaVrst (+) } \\
\text { CasaVrst (-) } \\
\text { Prenos_B (+) } \\
\text { Uporaba }(+)\end{array}$ & Zavrnjena & \\
\hline
\end{tabular}

Hic

Med človeškim kapitalom in pripadnostjo organizaciji kot sestavino organizacijske klime obstaja

UporabaVrst $(+)$

Delno

pozitivna medsebojna povezava.

Hič

Med človeškim kapitalom in razvojem kariere kot sestavino organizacijske klime obstaja pozitivna medsebojna povezava.

Hid

Med človeškim kapitalom ter zadovoljstvom zaposlenih in nagrajevanjem kot sestavino organizacijske klime obstaja pozitivna medsebojna povezava.

Uporaba $(+) \quad$ Delno

Hie

Med človeškim kapitalom ter strokovno usposo-

bljenostjo in učenjem kot sestavino organizacijske

klime obstaja pozitivna medsebojna povezava.

Vrst_B (+)
UporabaVrst $(+)$
Shranjev $(+)$

Vrst_B(+)
UporabaVrst $(+)$
CasaVrst $(+)$




\section{Glavna ugotovitev $H_{I}$}

Povzetek preverjanja podhipotez od Hia pa vse do Hie je na podlagi korelacijske analize in linearne multiple regresije pokazal, da lahko hipotezo $\mathrm{H}_{\mathrm{I}}$, $\gg$ Med človeškim kapitalom in organizacijsko klimo v turističnih agencijah obstaja pozitivna medsebojna povezava $\ll$, delno potrdimo, saj smo delno potrdili vse podhipoteze razen podhipoteze Hib.

\section{Preverjanje H2: Človeški kapital pozitivno vpliva na uspešnost poslovanja turističnih agencij.}

Preverjanje povezanosti med konstruktom človeški kapital in konstruktom uspešnost poslovanja smo izvedli s korelacijsko in regresijsko analizo. Model preverjanja obsega latentne spremenljivke obeh konstruktov, ki so bile pripravljene na podlagi izvedbe faktorske analize.

$\mathrm{V}$ preglednici 85 navajamo spremenljivke konstruktov človeški kapital in uspešnost poslovanja. Prve smo v posameznih podhipotezah hipoteze $\mathrm{H}_{2}$ uporabili kot neodvisne spremenljivke in jih primerjali s posamezno odvisno spremenljivko konstrukta uspešnost poslovanja.

Preglednica 85: Neodvisne spremenljivke konstrukta človeški kapital in upoštevane odvisne latentne spremenljivke konstrukta uspešnost poslovanja

Spremenljivke konstrukta človeški kapital, upoštevane kot neodvisne spremenljivke:

prenos znanja - nestimulativni (Prenos_A); izobraževanje s področja trženja (Vrst_A); izobraževanja s področja komuniciranja (Vrst_B); uporaba znanja na lastnih izkušnjah (UporabaVrst); čas izobraževanja (CasaVrst);

prenos znanja - timski (Prenos_B);

shranjevanje znanja (Shranjev);

pridobivanje znanja (Pridobiv);

uporaba znanja (Uporaba).
Spremenljivke konstrukta uspešnost poslovanja, upoštevane kot odvisne spremenljivke:

donosnost: (ROI, ROA, ROE);

rast: prihodki od prodaje (prihodki), povečanje števila zaposlenih (zaposleni), dobiček (dobicek), povečanje tržnega deleža na domačem trgu (rastı), povečanje tržnega deleža na tujem $\operatorname{trgu}($ rast2);

dobičkonosnost TA: v primerjavi z vsemi konkurenčnimi turističnimi agencijami/poslovalnicami (dobickonosnostı) in dobičkonosnost v primerjavi s turističnimi agencijami/ poslovalnicami, ki so na trgu enako število let in v enaki fazi razvoja (dobickonosnost2).

Preverjanje hipoteze $\mathrm{H}_{2}$ tako obsega tri podhipoteze, ki preverjajo povezanost konstrukta človeški kapital s posameznimi latentnimi odvisnimi spremenljivkami konstrukta uspešnost poslovanja.

Preverjanje podhipotez je izvedeno $\mathrm{v}$ dveh korakih. V prvem koraku s pomočjo korelacijske analize preverjamo jakost povezanosti med spremenljivkami konstrukta človeški kapital in posamezno spremenljivko konstrukta uspešnost poslovanja. Nato pa modele obravnavamo s pomočjo linearne regresijske analize ter ocenimo multipli regresijski model (multipli korelacijski koeficient, popravljeni determinacijski koeficient). 
Nazadnje ocenimo še vplivn posameznih spremenljivk (dimenzij) človeškega kapitala na posamezne latentne spremenljivke (dimenzije) uspešnosti poslovanja.

Hza: Človeški kapital pozitivno vpliva na donosnost (ROI, ROA, ROE) kot sestavino uspeřnosti poslovanja.

Pri preverjanju podhipoteze smo uporabili neodvisne spremenljivke konstrukta človeskki kapital in odvisno spremenljivko donosnost (ROI, ROA, ROE) kot sestavina uspešnosti poslovanja (preglednica 85).

Korelacije spremenljivk ČK so s spremenljivko donosnost kot sestavina UP pozitivne in $\mathrm{v} v$ seh primerih statistično značilne ( $\mathrm{p}<0,0 \mathrm{I} 4)$, vrednosti koeficientov pa so med 0,216 in 0,460 .

Ocena multiplega regresijskega modela je prikazana v preglednici 86 .

Preglednica 86: Ocena regresijskega modela za človeški kapital in donosnost kot sestavino uspešnosti poslovanja

\begin{tabular}{lc}
\hline Povzetek modela & \\
\hline $\mathrm{R}$ & 0,604 \\
$\mathrm{R}^{2}$ & 0,365 \\
Popravljen $\mathrm{R}^{2}$ & 0,304 \\
\hline ANOVA & \\
\hline F & 6,008 \\
P & 0,000 \\
\hline
\end{tabular}

$\mathrm{Na}$ osnovi multiplega korelacijskega koeficienta $\mathrm{R}=0,604$ ocenjujemo, da je povezanost odvisne spremenljivke donosnost kot sestavina uspešnosti poslovanja $\mathrm{z}$ neodvisnimi spremenljivkami človeškega kapitala zmerna in pozitivna. Popravljen determinacijski koeficient $\mathrm{R}^{2}=0,304 \mathrm{iz}$ kazuje, da lahko z vključenimi neodvisnimi spremenljivkami pojasnimo $30,4 \%$ variabilnosti odvisne spremenljivke donosnost kot sestavina uspešnosti poslovanja.

$\mathrm{Ob}$ pregledu regresijskih koeficientov in rezultatov t-testov lahko iz preglednice 87 razberemo, da so pri stopnji tveganja 0,05 statistično značilni regresijski koeficienti pri spremenljivkah: Prenos_A $\left(\mathrm{X}_{\mathrm{r}}\right.$, $\mathrm{b}=0,267, \mathrm{p}=0,00 \mathrm{I})$, Vrst_B $\left(\mathrm{X}_{2}, \mathrm{~b}=0,204, \mathrm{p}=0,0 \mathrm{I} 8\right)$ in UporabaVrst $\left(\mathrm{X}_{3}, \mathrm{~b}=0,316, \mathrm{p}=0,017\right)$.

$\mathrm{V}$ preglednici 87 so prikazani koeficienti regresijskega modela spremenljivk človeškega kapitala in spremenljivke donosnost kot sestavina uspešnosti poslovanja. 


\begin{tabular}{lccc} 
Koeficienti & b & t & P \\
\hline Konstanta) & $\mathrm{I}, 166$ & $\mathrm{I}, 989$ & 0,050 \\
Prenos_A & 0,267 & 3,462 & $0,00 \mathrm{I}$ \\
Vrst_A & 0,008 & 0,100 & $0,92 \mathrm{I}$ \\
Vrst_B & 0,204 & 2,407 & 0,018 \\
UporabaVrst & 0,316 & 2,439 & 0,017 \\
CasaVrst & $-0,217$ & $-1,837$ & 0,069 \\
Prenos_B & $-0,115$ & $-0,938$ & $0,35 \mathrm{I}$ \\
Shranjev & $-0,017$ & $-0,186$ & 0,853 \\
Pridobiv & 0,139 & $\mathrm{I}, 766$ & $0,08 \mathrm{I}$ \\
Uporaba & 0,070 & 0,597 & 0,552 \\
\hline
\end{tabular}

Hza: Človeški kapital pozitivno vpliva na donosnost kot sestavino uspešnosti poslovanja.

Sklep: Povezanost med konstruktom človeški kapital in spremenljivko donosnost kot sestavina uspešnosti poslovanja je pozitivna in pri vseh spremenljivkah tudi statistično značilna. Regresijska analiza je pokazala, da od devetih spremenljivk konstrukta človeški kapital le tri statistično značilno vplivajo na donosnost kot sestavino uspešnosti poslovanja. Ugotovili smo torej, da na donosnost kot sestavino uspešnosti poslovanja vplivajo spremenljivke Prenos_A, Vrst_B in UporabaVrst, zato lahko podhipotezo le delno potrdimo. To pomeni, da naj bodo turistične agencije za povečanje donosnosti kot sestavine uspešnosti poslovanja pozorne predvsem na spremenljivke konstrukta človeški kapital: prenos znanja, izobraževanja s področja komuniciranja in uporaba znanja pri lastnih izkušnjah.

Hzb: Človeški kapital pozitivno vpliva na rast (prihodki od prodaje, zaposleni, dobicek, rastr, rast2) kot sestavino uspešnosti poslovanja.

Pri preverjanju podhipoteze smo uporabili neodvisne spremenljivke konstrukta cloveški kapital in odvisno spremenljivko rast (prihodki od prodaje, zaposleni, dobicek, rasti, rast2) kot sestavina uspešnosti poslovanja (preglednica 85).

Korelacije spremenljivk ČK s spremenljivko rast kot sestavina UP so negativne in statistično značilne ( $\mathrm{p}<0,04 \mathrm{I})$ le pri dveh spremenljivkah, in sicer CasaVrst in Shranjev, vrednosti obeh statistično značilnih koeficientov pa sta $-0,172$ in $-0,266$. 
Ocena multiplega regresijskega modela je prikazana v preglednici 88 .

Preglednica 88: Ocena regresijskega modela za človeški kapital in rast kot sestavino

uspešnosti poslovanja

Povzetek modela

$\mathrm{R}$

$\mathrm{R}^{2}$

ANOVA

$\mathrm{Na}$ osnovi multiplega korelacijskega koeficienta $\mathrm{R}=0,3 \mathrm{I} 4$ ocenjujemo, da je povezanost odvisne spremenljivke rast $\mathrm{z}$ neodvisnimi spremenljivkami človeškega kapitala šibka in pozitivna. Popravljen determinacijski koeficient $\mathrm{R}^{2}=$ 0,0 2 izkazuje, da lahko $\mathrm{z}$ vključenimi neodvisnimi spremenljivkami pojasnimo le $1,2 \%$ variabilnosti odvisne spremenljivke rast kot sestavina uspešnosti poslovanja.

$\mathrm{Ob}$ pregledu regresijskih koeficientov in rezultatov t-testov iz preglednice 89 razberemo, da so pri stopnji tveganja o,05 statistično značilni regresijski koeficienti pri spremenljivki Shranjev $\left(X_{1}, b=-0,162\right.$, $\mathrm{p}=0,028)$. Vendar pa to glede na dejstvo, da model kot celota ni statistično značilen, nima nikakršne teže.

V preglednici 89 so prikazani koeficienti regresijskega modela spremenljivk človeškega kapitala in spremenljivka rast kot sestavina uspešnosti poslovanja.

$\mathrm{H}_{2}$ b: Človeški kapital pozitivno vpliva na rast kot sestavino uspeřnostiposlovanja.

Sklep: Povezanost med konstruktom človeški kapital in spremenljivko rast kot sestavina uspešnosti poslovanja je negativna in le pri dveh spremenljivkah statistično značilna. Regresijska analiza je pokazala, da model ni statistično značilen, kar pomeni, da ne moremo trditi, da bi človeški kapital vplival na rast kot sestavino uspešnosti poslovanja, zato podhipotezo zavrnemo. Rezultat je pričakovan, saj so v turbulentnih obdobjih na področju gospodarstva zunanji vplivi na rast običajno mnogo močnejši od notranjih. 
Preglednica 89: Koeficienti regresijskega modela spremenljivk človeškega kapitala in spremenljivke rast kot sestavina uspešnosti poslovanja

\section{Kocficienti}

$\begin{array}{ccc}\mathrm{b} & \mathrm{t} & \mathrm{P} \\ 2,451 & 5,396 & 0,000 \\ 0,088 & \mathrm{I}, 480 & 0,142 \\ -0,016 & -0,245 & 0,807 \\ -0,018 & -0,268 & 0,789 \\ 0,110 & \mathrm{I}, 092 & 0,278 \\ -0,049 & -0,536 & 0,593 \\ -0,040 & -0,417 & 0,678 \\ -0,162 & -2,228 & 0,028 \\ -0,027 & -0,445 & 0,657 \\ 0,004 & 0,045 & 0,964\end{array}$

Hzc: Človeški kapital pozitivno vpliva na dobičkonosnost TA (dobickonosnostI, dobickonosnost2) kot sestavino uspeřnosti poslovanja.

Pri preverjanju podhipoteze smo uporabili neodvisne spremenljivke konstrukta človeški kapital in odvisno spremenljivko dobičkonosnost TA (dobickonosnostr, dobickonosnost2) kot sestavina uspešnosti poslovanja (preglednica 85).

Korelacije spremenljivk ČK so s spremenljivko dobičkonosnost TA kot sestavina UP pozitivne (5) in negativne (4) ter statistično značilne $(\mathrm{p}<0,039)$ le pri dveh spremenljivkah, in sicer Vrst_A in UporabaVrst z vrednostma koeficientov 0,226 in 0,174 .

Ocena multiplega regresijskega modela je prikazana v preglednici 90.

Preglednica 90: Ocena regresijskega modela za človeški kapital in dobičkonosnost TA kot sestavino uspešnosti poslovanja

\section{Povzetek modela}

$\mathrm{R}$

$\mathrm{R}^{2}$

\section{ANOVA}


$\mathrm{Na}$ osnovi multiplega korelacijskega koeficienta $\mathrm{R}=0,33 \mathrm{I}$ ocenjujemo, da je povezanost odvisne spremenljivke dobičkonosnost TA kot sestavina uspešnosti poslovanja $\mathrm{z}$ neodvisnimi spremenljivkami človeškega kapitala šibka in pozitivna. Popravljen determinacijski koeficient $\mathrm{R}^{2}=0,024$ izkazuje, da lahko $\mathrm{z}$ vključenimi neodvisnimi spremenljivkami pojasnimo le $2,4 \%$ variabilnosti odvisne spremenljivke dobičkonosnost TA kot sestavina uspešnosti poslovanja.

Ob pregledu regresijskih koeficientov in rezultatov t-testov lahko iz preglednice 9I razberemo, da je pri stopnji tveganja o,05 statistično značilni regresijski koeficienti pri spremenljivki Vrst_A $(X, b=0,222$, $\mathrm{p}=0,048)$. Vendar pa ne glede na to, da model kot celota ni statistično značilen, to dejstvo nima teže.

$\mathrm{V}$ preglednici 9I so prikazani koeficienti regresijskega modela spremenljivk človeškega kapitala in spremenljivke dobičkonosnost TA kot sestavina uspešnosti poslovanja.

\section{Preglednica 91: Koeficienti regresijskega modela spremenljivk človeškega kapitala in spremenljivke dobičkonosnost TA kot sestavina uspešnosti poslovanja}

\begin{tabular}{lccc} 
Kocficienti & $\mathrm{b}$ & $\mathrm{t}$ & $\mathrm{P}$ \\
\hline (Konstanta) & 0,952 & $\mathrm{I}, 200$ & 0,233 \\
Prenos_A & $-0,003$ & $-0,029$ & 0,977 \\
Vrst_A & 0,222 & 2,001 & 0,048 \\
Vrst_B & $-0,089$ & $-0,774$ & 0,441 \\
UporabaVrst & 0,216 & 1,231 & 0,222 \\
CasaVrst & $-0,289$ & $-1,810$ & 0,073 \\
Prenos_B & $-0,013$ & $-0,076$ & 0,940 \\
Shranjev & 0,023 & 0,184 & 0,854 \\
Pridobiv & 0,059 & 0,551 & 0,583 \\
Uporaba & 0,127 & 0,800 & 0,425 \\
\hline
\end{tabular}

H2c: Človeški kapital pozitivno vpliva na dobičkonosnost TA kot sestavino uspešnosti poslovanja.

Sklep: Povezanost med konstruktom človeški kapital in spremenljivko dobičkonosnost TA kot sestavina uspešnosti poslovanja je le pri dveh spremenljivkah statistično značilna. Regresijska analiza je pokazala, da model ni statistično značilen, kar pomeni, da ne moremo trditi, da bi človeški kapital vplival na dobičkonosnost TA kot sestavino uspešnosti poslovanja, zato podhipotezo zavrnemo. Rezultat je pričakovan, saj so 
$\mathrm{v}$ turbulentnih obdobjih na področju gospodarstva zunanji vplivi na dobičkonosnost TA običajno mnogo močnejši od notranjih.

$\mathrm{V}$ preglednici 92 sledi povzetek preverjanja podhipotez, s katerimi smo preverjali $\mathrm{H}_{2}$.

Preglednica 92: Povzetek preverjanja hipoteze $\mathrm{H}_{2}$

\begin{tabular}{|c|c|c|c|}
\hline Povzetek preverjanja hipoteze $\mathrm{H}_{2}$ & $\begin{array}{c}\text { Spremenljivke - statistično } \\
\text { značilen vpliv }\end{array}$ & Potrditev & Ugotovitev \\
\hline $\begin{array}{l}\mathrm{H}_{2} \\
\text { Človeški kapital pozitivno vpliva na } \\
\text { uspešnost poslovanja turističnih agencij. }\end{array}$ & & & $\begin{array}{l}\text { Nipousem } \\
\text { zavrnjena }\end{array}$ \\
\hline $\begin{array}{l}\mathrm{H}_{2 \mathrm{a}} \\
\text { Človeški kapital pozitivno vpliva na donos- } \\
\text { nost kot sestavino uspešnosti poslovanja. }\end{array}$ & $\begin{array}{c}\text { Prenos_A }(+) \\
\text { Vrst_B }(+) \\
\text { UporabaVrst }(+)\end{array}$ & Delno & \\
\hline $\begin{array}{l}\mathrm{H}_{2} \mathrm{~b} \\
\text { Človeški kapital pozitivno vpliva na rast kot } \\
\text { sestavino uspešnosti poslovanja. }\end{array}$ & Shranjev $(-)$ & $\mathrm{Ne}$ & \\
\hline $\begin{array}{l}\mathrm{H}_{2 \mathrm{C}} \\
\text { Človeški kapital pozitivno vpliva na } \\
\text { dobičkonosnost kot sestavino uspešnosti } \\
\text { poslovanja. }\end{array}$ & Vrst_A (+) & $\mathrm{Ne}$ & \\
\hline
\end{tabular}

\section{Glavna ugotovitev $\mathrm{H}_{2}$}

Povzetek preverjanja podhipotez $\mathrm{H}_{2} \mathrm{a}, \mathrm{H}_{2} \mathrm{~b}$ in $\mathrm{H}_{2}$ c je na podlagi korelacijske analize in linearne multiple regresije pokazal, da hipoteze $\mathrm{H}_{2}$, »Človeški kapital pozitivno vpliva na uspešnost poslovanja turističnih agencij, « ne zavrnemo povsem, saj je regresijski model statistično značilen le pri vplivu človeškega kapitala na donosnost kot sestavino uspešnosti poslovanja, medtem ko pri vplivu človeškega kapitala na rast prodaje in pri dobičkonosnosti TA kot sestavini uspešnosti poslovanja statistično značilen. Delno smo potrdili le eno podhipotezo, dveh pa nismo mogli potrditi in smo ju zavrnili; hipoteza $\mathrm{H}_{2}$ tako ni povsem zavrnjena.

\section{Preverjanje $\mathrm{H}_{3}$ : Organizacijska klima pozitivno vpliva na uspešnost poslovanja turističnih agencij. \\ Preverjanje povezanosti med konstruktom organizacijska klima in kons- truktom uspešnost poslovanja smo izvedli s korelacijsko in z regresijsko analizo. Model preverjanja obsega latentne spremenljivke obeh konstruk- tov, ki so bile pripravljene na podlagi izvedbe faktorske analize.}


V preglednici 93 navajamo latentne spremenljivke konstruktov organizacijska klima in uspešnost poslovanja. Prve smo v posameznih podhipotezah hipoteze $\mathrm{H}_{3}$ uporabili kot neodvisne spremenljivke in jih primerjali s posamezno odvisno spremenljivko konstrukta uspešnost poslovanja.

Preglednica 93: Neodvisne spremenljivke konstrukta organizacijska klima in upoštevane odvisne latentne spremenljivke konstrukta uspešnost poslovanja

Spremenljivke konstrukta organizacijska klima, upoštevane kot neodvisne spremenljivke:

notranji odnosi (OdnosKakovMotiv); vodenje (delegiranje dela) (Vodenje); pripadnost organizaciji (Pripadnost); razvoj kariere (Kariera); zadovoljstvo zaposlenih in nagrajevanje (ZadovoljNagrajevanj); strokovno usposabljanje in učenje (Usposobljenost).
Spremenljivke konstrukta uspešnost poslovanja, upoštevane kot odvisne spremenljivke:

donosnost: ROI, ROA, ROE;

rast: prihodki od prodaje (prihodki), povečanje števila zaposlenih (zaposleni), dobiček (dobicek), povečanje tržnega deleža na domačem trgu (rasti), povečanje tržnega deleža na tujem trgu (rast2);

dobičkonosnost TA: v primerjavi z vsemi

konkurenčnimi turističnimi agencijami/poslovalnicami (dobickonosnostı) in dobičkonosnost v primerjavi s turističnimi agencijami/poslovalnicami, ki so na trgu enako število let in v enaki fazi razvoja (dobickonosnost2).

Preverjanje hipoteze $\mathrm{H}_{3}$ tako obsega tri podhipoteze, ki preverjajo povezanost konstrukta organizacijska klima s posameznimi latentnimi odvisnimi spremenljivkami konstrukta uspešnost poslovanja.

Preverjanje podhipotez je izvedeno $\mathrm{v}$ dveh korakih. V prvem koraku $s$ pomočjo korelacijske analize preverjamo jakost povezanosti med spremenljivkami konstrukta organizacijska klima in posamezno spremenljivko konstrukta uspešnost poslovanja. Nato pa modele obravnavamo s pomočjo linearne regresijske analize ter ocenimo multipli regresijski model (multipli korelacijski koeficient, popravljeni determinacijski koeficient). Nazadnje ocenimo še vplivnost posameznih spremenljivk (dimenzij) organizacijske klime na posamezne latentne spremenljivke (dimenzije) uspešnosti poslovanja.

$H_{3}$ : Organizacijska klima pozitivno vpliva na donosnost (ROI, ROA, ROE) kot sestavino uspešnosti poslovanja.

Pri preverjanju podhipoteze smo uporabili neodvisne spremenljivke konstrukta organizacijska klima in odvisno spremenljivko donosnost (ROI, ROA, ROE) kot sestavina uspešnosti poslovanja (preglednica 93).

Korelacije spremenljivk OK s spremenljivko donosnost kot sestavina UP so pozitivne in v vseh primerih, razen pri spremenljivki OdnosKakovMotiv, statistično značilne $(\mathrm{p}<0,043)$, vrednosti koeficientov pa so med 0,170 in 0,378 . 
Ocena multiplega regresijskega modela je prikazana v preglednici 94.

Preglednica 94: Ocena regresijskega modela za organizacijsko klimo in donosnost kot sestavino uspešnosti poslovanja

\begin{tabular}{lr}
\hline Povzetek modela & \\
\hline $\mathrm{R}$ & 0,509 \\
$\mathrm{R}^{2}$ & 0,259 \\
Popravljen R & \\
\hline ANOVA & 0,213 \\
\hline F & \\
P & 5,654 \\
\hline
\end{tabular}

$\mathrm{Na}$ osnovi multiplega korelacijskega koeficienta $\mathrm{R}=0,509$ ocenjujemo, da je povezanost odvisne spremenljivke donosnost kot sestavina uspešnosti poslovanja z neodvisnimi spremenljivkami organizacijske klime zmerna in pozitivna. Popravljen determinacijski koeficient $\mathrm{R}^{2}=0,2 \mathrm{I} 3 \mathrm{iz}-$ kazuje, da lahko z vključenimi neodvisnimi spremenljivkami pojasnimo 21,3\% variabilnosti odvisne spremenljivke donosnost kot sestavina uspešnosti poslovanja.

Ob pregledu regresijskih koeficientov in rezultatov t-testov lahko iz preglednice 95 razberemo, da sta pri stopnji tveganja o,05 statistično značilna regresijska koeficienta pri spremenljivkah Vodenje $\left(X_{1}, b=0,352\right.$, $\mathrm{p}=0,044)$ in Kariera $\left(\mathrm{X}_{2}, \mathrm{~b}=0,335, \mathrm{p}=0,036\right)$.

$\mathrm{V}$ preglednici 95 so prikazani koeficienti regresijskega modela spremenljivk organizacijska klima in donosnost kot sestavina uspešnosti poslovanja.

H3a: Organizacijska klima pozitivno vpliva na donosnost kot sestavino uspešnosti poslovanja.

Sklep: Povezanost med organizacijsko klimo in spremenljivko donosnost kot sestavina uspešnosti poslovanja je pozitivna in pri vseh spremenljivkah, razen pri eni, tudi statistično značilna. Regresijska analiza je pokazala, da od šestih spremenljivk organizacijske klime le dve statistično značilno vplivata na donosnost kot sestavino uspešnosti poslovanja, zato lahko podhipotezo le delno potrdimo. Ugotovili smo torej, da na donosnost kot sestavino uspešnosti poslovanja vplivata spremenljivki vodenje in kariera, kar pomeni, da naj bodo turistične agencije za povečanje donosnosti kot sestavine uspešnosti poslovanja pozorne predvsem na vodenje (delegiranje dela) in razvoj kariere. 
Preglednica 95: Koeficienti regresijskega modela spremenljivk organizacijska klima in donosnost kot sestavina uspešnosti poslovanja

\begin{tabular}{lccc} 
Koeficienti & $\mathrm{b}$ & $\mathrm{t}$ & $\mathrm{P}$ \\
(Konstanta) & $-2,76 \mathrm{1}$ & $-2,428$ & 0,017 \\
OdnosKakovMotiv & $-0,443$ & $-1,494$ & 0,139 \\
Vodenje & 0,352 & 2,045 & 0,044 \\
Pripadnost & $-0,172$ & $-0,842$ & 0,402 \\
Kariera & 0,335 & 2,126 & 0,036 \\
ZadovoljNagrajevanj & 0,298 & 1,757 & 0,082 \\
Usposobljenost & 0,326 & 1,921 & 0,058 \\
\hline
\end{tabular}

Opomba: spremenljivka vodenje se nanaša na delegiranje dela.

$\mathrm{H}_{3}$ b: Organizacijska klima pozitivno vpliva na rast (prihodki od prodaje, zaposleni, dobicek, rastı, rast2) kot sestavino uspešnosti poslovanja.

Za preverjanje podhipoteze smo uporabili neodvisne spremenljivke konstrukta organizacijska klima in odvisno spremenljivko rast (pribodki od prodaje, zaposleni, dobicek, rasti, rast2) kot sestavina organizacijske klime (preglednica 93).

Korelacije spremenljivk OK s spremenljivko rast kot sestavina UP so pozitivne (4) in negativne ( 2 ), v nobenem primeru pa niso statistično značilne ( $p>0,06)$. Vrednosti koeficientov so med -0,154 in 0,1 19 .

Ocena multiplega regresijskega modela je prikazana v preglednici 96.

Preglednica 96: Ocena regresijskega modela za organizacijsko klimo in rast kot sestavino uspešnosti poslovanja

\begin{tabular}{lc}
\hline Povzetek modela & \\
\hline $\mathrm{R}$ & 0,332 \\
$\mathrm{R}^{2}$ & 0,110 \\
Popravljen $\mathrm{R}^{2}$ & 0,055 \\
\hline ANOVA & \\
\hline F & 2,006 \\
P & 0,072 \\
\hline
\end{tabular}

$\mathrm{Na}$ osnovi multiplega korelacijskega koeficienta $\mathrm{R}=0,332$ ocenjujemo, da je povezanost odvisne spremenljivke rast kot sestavina uspešnosti poslovanja z neodvisnimi spremenljivkami organizacijske klime šibka in pozitivna. Popravljen determinacijski koeficient $\mathrm{R}^{2}=0,055$ izkazu- 
je, da lahko z vključenimi neodvisnimi spremenljivkami pojasnimo le $5,5 \%$ variabilnosti odvisne spremenljivke rast kot sestavina uspešnosti poslovanja.

Ob pregledu regresijskih koeficientov in rezultatov t-testov lahko iz preglednice 97 razberemo, da sta pri stopnji tveganja o,0 5 statistično značilna regresijska koeficienta pri spremenljivkah Vodenje $\left(X_{\mathrm{r}}, \mathrm{b}=0,200\right.$, $\mathrm{p}=0,022)$ in ZadovoljNagrajevanj $\left(\mathrm{X}_{2},=-0,199, \mathrm{p}=0,02 \mathrm{I}\right)$.

$\mathrm{V}$ preglednici 97 so prikazani koeficienti regresijskega modela spremenljivk organizacijske klime in rasti kot sestavine uspešnosti poslovanja.

Preglednica 97: Koeficienti regresijskega modela spremenljivk organizacijske klime in rasti

kot sestavine uspešnosti poslovanja

\begin{tabular}{lccc} 
Koeficienti & $\mathrm{b}$ & $\mathrm{t}$ & $\mathrm{P}$ \\
(Konstanta) & $\mathrm{1}, 668$ & 2,939 & 0,004 \\
OdnosKakovMotiv & 0,091 & 0,613 & 0,542 \\
Vodenje & 0,200 & 2,330 & 0,022 \\
Pripadnost & 0,051 & 0,502 & 0,617 \\
Kariera & 0,065 & 0,823 & 0,413 \\
ZadovoljNagrajevanj & $-0,199$ & $-2,346$ & 0,021 \\
Usposobljenost & $-0,147$ & $-1,741$ & 0,085 \\
\hline
\end{tabular}

$\mathrm{H}_{3}$ b: Organizacijska klima pozitivno vpliva na rast kot sestavino uspešnosti poslovanja.

Sklep: Povezanosti med organizacijsko klimo in spremenljivko rast kot sestavina uspešnosti poslovanja ni. Regresijska analiza je pokazala, da model ni statistično značilen (statistično značilni sta le dve spremenljivki: vodenje (delegiranje dela) in zadovoljstvo zaposlenih ter nagrajevanje (koeficient slednje je negativen). Te podhipoteze ne moremo potrditi, kar pomeni, da ne moremo trditi, da bi človeški kapital vplival na rast kot sestavino uspešnosti poslovanja- Tako podhipotezo zavrnemo.

$\mathrm{H}_{3}$ : Organizacijska klima pozitivno vpliva na dobičkonosnost TA (dobickonosnostr, dobickonosnost2) kot sestavino uspešnosti poslovanja.

Pri preverjanju podhipoteze smo uporabili neodvisne spremenljivke konstrukta organizacijska klima in odvisno spremenljivko dobičkonosnost TA (dobickonosnostI, dobickonosnost2) kot sestavina uspešnosti poslovanja (preglednica 93). 
Korelacije spremenljivk OK s spremenljivko dobičkonosnost TA kot sestavina UP so pozitivne (3) in negativne (3) ter niso statistično značilne $(\mathrm{p}>0,099)$, razen pri spremenljivki Pripadnost. Vrednost koeficienta je 0,276 .

Ocena multiplega regresijskega modela je prikazana v preglednici 98 .

Preglednica 98: Ocena regresijskega modela za organizacijsko klimo in dobičkonosnost TA

kot sestavino uspešnosti poslovanja

\begin{tabular}{lc}
\hline Povzetek modela & \\
\hline $\mathrm{R}$ & 0,442 \\
$\mathrm{R}^{2}$ & 0,195 \\
Popravljen R2 & 0,146 \\
\hline ANOVA & \\
\hline F & 3,927 \\
P & 0,001 \\
\hline
\end{tabular}

$\mathrm{Na}$ osnovi multiplega korelacijskega koeficienta $\mathrm{R}=0,442$ ocenjujemo, da je povezanost odvisne spremenljivke dobičkonosnost TA kot sestavina uspešnosti poslovanja $\mathrm{z}$ neodvisnimi spremenljivkami organizacijske klime zmerna in pozitivna. Popravljen determinacijski koeficient $\mathrm{R}^{2}=0, \mathrm{I} 46$ izkazuje, da lahko $\mathrm{z}$ vključenimi neodvisnimi spremenljivkami pojasnimo i 4,6 \% variabilnosti odvisne spremenljivke dobičkonosnost TA kot sestavina uspešnosti poslovanja.

Ob pregledu regresijskih koeficientov in rezultatov t-testov lahko iz preglednice 99 razberemo, da so pri stopnji tveganja 0,05 statistično značilni regresijski koeficienti pri spremenljivkah Pripadnost $\left(X_{1}, b=0,636\right.$, $\mathrm{p}=0,000)$, Kariera $\left(\mathrm{X}_{2}, \mathrm{~b}=-0,268, \mathrm{p}=0,044\right)$ in Usposobljenost $\left(\mathrm{X}_{3}\right.$, $\mathrm{b}=-0,3 \mathrm{I} 2, \mathrm{p}=0,030)$.

$\mathrm{V}$ preglednici 99 so prikazani koeficienti regresijskega modela spremenljivk organizacijska klima in dobičkonosnost TA kot sestavina uspešnosti poslovanja.

$H_{3}$ c: Organizacijska klima pozitivno vpliva na dobičkonosnost TA kot sestavino uspešnosti poslovanja.

Sklep: Povezanost med človeškim kapitalom in spremenljivko dobičkonosnost TA kot sestavina uspešnosti poslovanja je le pri eni spremenljivki statistično značilna. Regresijska analiza je pokazala, da ima v modelu ena spremenljivka pozitiven vpliv na dobičkonosnost TA kot sestavino uspešnosti poslovanja (pripadnost organizaciji), dve pa negativno (razvoj 
kariere ter strokovna usposobljenost in učenje); te podhipoteze torej ne moremo potrditi in jo zato zavrnemo.

Preglednica 99: Koeficienti regresijskega modela spremenljivk organizacijska klima in dobičkonosnost TA kot sestavina uspešnosti poslovanja

\begin{tabular}{lccc} 
Koeficienti & $\mathrm{b}$ & $\mathrm{t}$ & $\mathrm{P}$ \\
\hline Konstanta) & $-0,080$ & $-0,084$ & 0,933 \\
OdnosKakovMotiv & 0,448 & $\mathrm{I}, 8 \mathrm{II}$ & 0,073 \\
Vodenje & 0,088 & 0,616 & 0,539 \\
Pripadnost & 0,636 & 3,740 & 0,000 \\
Kariera & $-0,268$ & $-2,039$ & 0,044 \\
ZadovoljNagrajevanj & $-0,179$ & $-\mathrm{I}, 264$ & 0,209 \\
Usposobljenost & $-0,312$ & $-2,203$ & 0,030 \\
\hline
\end{tabular}

V preglednici roo sledi povzetek preverjanja podhipotez, s katerimi smo preverjali $\mathrm{H}_{3}$.

Preglednica ıoo: Povzetek preverjanja hipoteze $\mathrm{H}_{3}$

\begin{tabular}{|c|c|c|c|}
\hline Povzetek preverjanja hipoteze $\mathrm{H}_{3}$ & $\begin{array}{l}\text { Spremenljivke - statistično } \\
\text { značilen vpliv }\end{array}$ & Potrditev & Ugotovitev \\
\hline $\begin{array}{l}\mathrm{H}_{3} \\
\text { Organizacijska klima pozitivno vpliva na } \\
\text { uspešnost poslovanja turističnih agencij. }\end{array}$ & & & $\begin{array}{l}\text { Nipovsem } \\
\text { zavrnjena }\end{array}$ \\
\hline $\begin{array}{l}\mathrm{H}_{3} \mathrm{a} \\
\text { Organizacijska klima pozitivno vpliva na } \\
\text { donosnost kot sestavino uspešnosti poslovanja. }\end{array}$ & $\begin{array}{l}\text { Vodenje }(+) \\
\text { Kariera }(+)\end{array}$ & Delno & \\
\hline $\begin{array}{l}\mathrm{H}_{3} \mathrm{~b} \\
\text { Organizacijska klima pozitivno vpliva na rast } \\
\text { kot sestavino uspešnosti poslovanja. }\end{array}$ & $\begin{array}{c}\text { Vodenje }(+) \\
\text { ZadovoljNagrajevanje (-) }\end{array}$ & $\mathrm{Ne}$ & \\
\hline $\begin{array}{l}\mathrm{H}_{3 \mathrm{C}} \\
\text { Organizacijska klima pozitivno vpliva na do- } \\
\text { bičkonosnost kot sestavino uspešnosti poslo- } \\
\text { vanja. }\end{array}$ & $\begin{array}{l}\text { Pripadnost }(+) \\
\text { Kariera }(-) \\
\text { Usposobljenost }(-)\end{array}$ & $\mathrm{Ne}$ & \\
\hline
\end{tabular}

\section{Glavna ugotovitev $\mathrm{H}_{3}$}

Povzetek preverjanja podhipotez $\mathrm{H}_{3} \mathrm{a}, \mathrm{H}_{3} \mathrm{~b}$ in $\mathrm{H}_{3} \mathrm{c}$ je na podlagi korelacijske analize in linearne multiple regresije pokazal, da hipoteze $\mathrm{H}_{3}$, »Organizacijska klima pozitivno vpliva na uspešnost poslovanja turističnih agencij «, ne moremo povsem zavrniti, saj smo ugotovili, da organizacijska klima statistično značilno pozitivno delno vpliva le na donosnost kot sestavino uspešnosti poslovanja, na rast in dobičkonosnost TA (sesta- 
vini uspešnosti poslovanja) turističnih agencij pa ne. Delno smo potrdili le eno izmed podhipotez, dveh pa nismo mogli potrditi, zato te hipoteze ne moremo povsem zavrniti. 



\section{Razvoj celotnega strukturnega modela vpliva človeškega kapitala in organizacijske klime na uspešnost poslovanja}

Celoten strukturni model smo izvedli na podlagi več korakov, pri čemer smo upoštevali zastavljene hipoteze $s$ podhipotezami in šele nato izoblikovali celoten strukturni model.

Strukturni model povezanosti človeškega kapitala in organizacijske klime

Ponazoritev celotnega strukturnega modela povezanosti človeškega kapitala in organizacijske klime kaže slika ı。.

Vidimo, da je model vseboval 9 opazovanih spremenljivk s področja človeškega kapitala (prenos znanja - nestimulativni, izobraževanje - trženje, izobraževanja - komuniciranje, uporaba znanja na lastnih izkušnjah, čas izobraževanj, prenos znanja - timski, shranjevanje znanja in pridobivanje znanja) in 6 opazovanih spremenljivk s področja organizacijske klime (notranji odnosi, vodenje (delegiranje dela), pripadnost organizaciji, razvoj kariere, zadovoljstvo zaposlenih in nagrajevanje ter strokovna usposobljenost in učenje).

V celotnem strukturnem modelu je tako sodelovalo is opazovanih spremenljivk. Povezanost med spremenljivkami konstrukta človeški kapital in spremenljivkami konstrukta organizacijska klima je enostranska in poteka $\mathrm{v}$ smeri od konstrukta človeški kapital h konstruktu organizacijska klima (slika ro). 
V preglednici ıo so prikazani standardizirani regresijski koeficienti in njihove statistične značilnosti za strukturni model povezanosti človeškega kapitala in organizacijske klime.

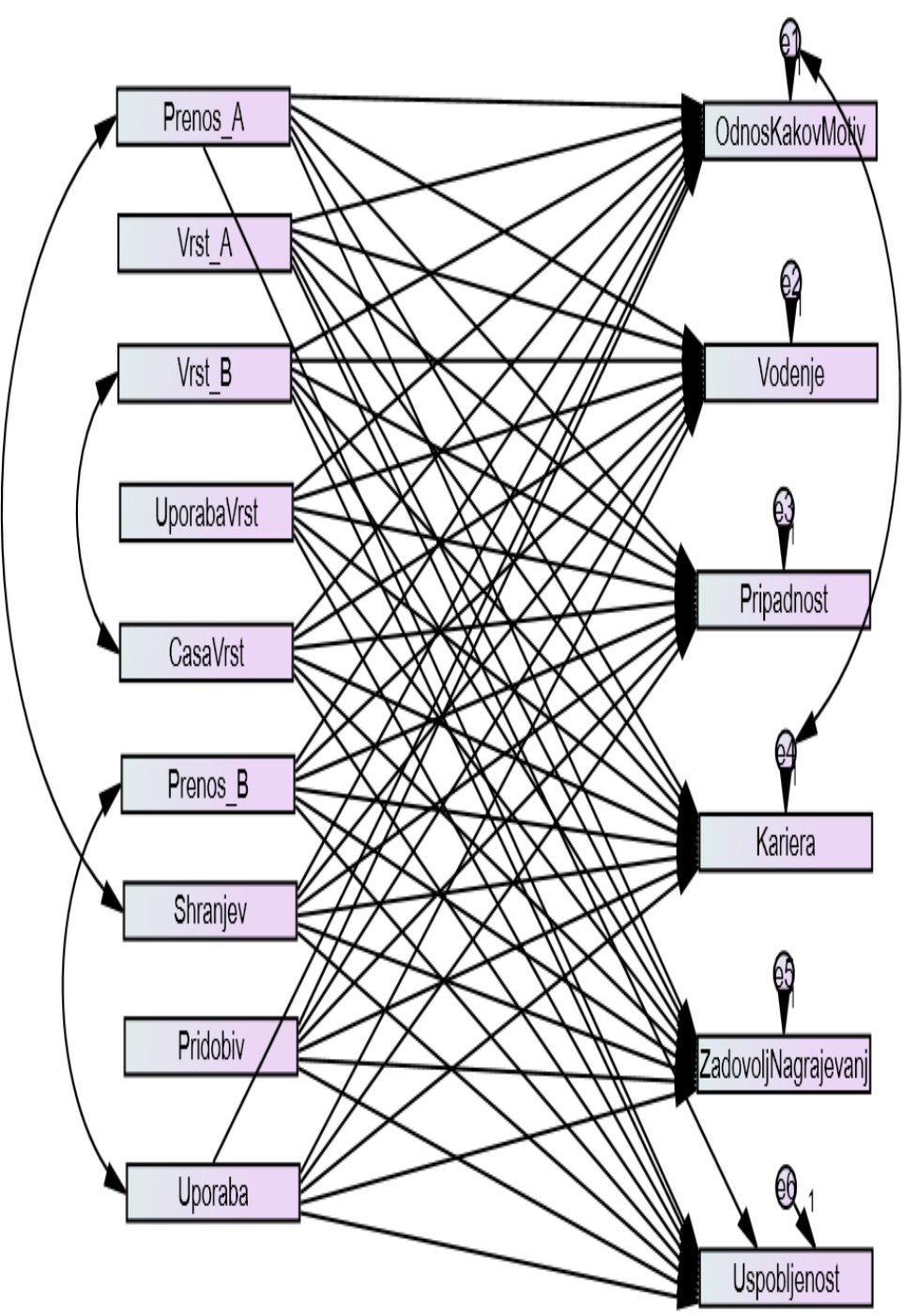

Slika ı: Strukturni model povezanosti človeškega kapitala in organizacijske klime

Hi-kvadrat $=257,672, \mathrm{df}=47, \mathrm{p}=0,000$

Opombe: $\mathrm{CFI}=0,648, \mathrm{NFI}=0,634, \mathrm{RFI}=0,182, \mathrm{RMSEA}=0,209$,

PCLOSE $=0,000$.

Legenda: e ....e6 = faktorji napake. 
Preglednica ıо : Standardizirani regresijski koeficienti in njihove statistične značilnosti za strukturni model povezanosti človeškega kapitala in organizacijske klime

\begin{tabular}{|c|c|c|c|c|}
\hline $\begin{array}{c}\text { Spremenljivke } \\
\text { organizacijske klime }\end{array}$ & Smer vpliva & $\begin{array}{l}\text { Spremenljivke } \\
\text { človeškega kapitala }\end{array}$ & $\begin{array}{l}\text { Standardiziran re- } \\
\text { gresijski koeficient }\end{array}$ & $\begin{array}{c}\text { Statistična } \\
\text { značilnost }(p)\end{array}$ \\
\hline OdnosKakovMotiv & $<--$ & Prenos_A & $-0,145$ & 0,132 \\
\hline OdnosKakovMotiv & $<--$ & Vrst_A & 0,073 & 0,346 \\
\hline OdnosKakovMotiv & $<--$ & Vrst_B & $-0,033$ & 0,704 \\
\hline OdnosKakovMotiv & $<--$ & UporabaVrst & 0.184 & 0,017 \\
\hline OdnosKakovMotiv & $<--$ & CasaVrst & 0,160 & 0,068 \\
\hline OdnosKakovMotiv & $<--$ & Prenos_B & 0,112 & 0,237 \\
\hline OdnosKakovMotiv & $<--$ & Shranjev & $-0,164$ & 0,088 \\
\hline OdnosKakovMotiv & $<--$ & Pridobiv & 0,056 & 0,467 \\
\hline Vodenje & $<--$ & Vrst_A & $-0,220$ & ०,००I \\
\hline Vodenje & $<--$ & Vrst_B & 0,267 & $* * *$ \\
\hline Vodenje & $<--$ & Prenos_A & 0,117 & 0,177 \\
\hline Vodenje & $<--$ & UporabaVrst & 0,320 & $* *$ \\
\hline Vodenje & $<--$ & CasaVrst & $-0,250$ & 0,002 \\
\hline Vodenje & $<-$ & Prenos_B & 0,203 & 0,017 \\
\hline Vodenje & $<--$ & Shranjev & O,OII & 0,898 \\
\hline Vodenje & $<-$ & Pridobiv & $-0,066$ & 0,339 \\
\hline Vodenje & $<--$ & Uporaba & 0,369 & $* *$ \\
\hline Pripadnost & $<--$ & Prenos_A & $-0,109$ & 0,305 \\
\hline Pripadnost & $<--$ & Vrst_A & 0,077 & 0,364 \\
\hline Pripadnost & $<--$ & Vrst_B & 0,123 & 0,206 \\
\hline Pripadnost & $<--$ & UporabaVrst & 0,390 & $* *$ \\
\hline Pripadnost & $<--$ & CasaVrst & $-0,092$ & 0,342 \\
\hline Pripadnost & $<--$ & Prenos_B & 0,013 & 0,898 \\
\hline Pripadnost & $<--$ & Shranjev & 0,165 & 0,122 \\
\hline Pripadnost & $<--$ & Pridobiv & $-0,162$ & 0,058 \\
\hline Pripadnost & $<--$ & Uporaba & 0,182 & 0,082 \\
\hline Kariera & $<--$ & Prenos_A & 0,028 & 0,794 \\
\hline Kariera & $<--$ & Vrst_A & 0,185 & 0,032 \\
\hline Kariera & $<--$ & Vrst_B & 0,017 & 0,863 \\
\hline Kariera & $<--$ & UporabaVrst & 0,112 & 0,192 \\
\hline Kariera & $<--$ & CasaVrst & ০,০І० & 0,921 \\
\hline Kariera & $<--$ & Prenos_B & 0,031 & 0,766 \\
\hline
\end{tabular}




\begin{tabular}{|c|c|c|c|c|}
\hline $\begin{array}{c}\text { Spremenljivke } \\
\text { organizacijske klime }\end{array}$ & Smer vpliva & $\begin{array}{l}\text { Spremenljivke } \\
\text { človeškega kapitala }\end{array}$ & $\begin{array}{l}\text { Standardiziran re- } \\
\text { gresijski koeficient }\end{array}$ & $\begin{array}{c}\text { Statistična } \\
\text { značilnost }(\mathbf{p})\end{array}$ \\
\hline Kariera & $<--$ & Shranjev & 0,133 & 0,216 \\
\hline Kariera & $<--$ & Pridobiv & $-0,188$ & 0,029 \\
\hline Kariera & $<--$ & Uporaba & 0,344 & ০,০०I \\
\hline OdnosKakovMotiv & $<--$ & Uporaba & 0,425 & $* * *$ \\
\hline ZadovoljNagrajevanj & $<--$ & Prenos_A & $-0,033$ & 0,757 \\
\hline ZadovoljNagrajevanj & $<--$ & Vrst_A & 0,023 & 0,785 \\
\hline ZadovoljNagrajevanj & $<--$ & Vrst_B & 0,320 & $* *$ \\
\hline ZadovoljNagrajevanj & $<--$ & UporabaVrst & 0,224 & 0,009 \\
\hline ZadovoljNagrajevanj & $<--$ & CasaVrst & $-0,003$ & 0,973 \\
\hline ZadovoljNagrajevanj & $<--$ & Prenos_B & 0,166 & 0,113 \\
\hline ZadovoljNagrajevanj & $<--$ & Shranjev & 0,262 & 0,014 \\
\hline ZadovoljNagrajevanj & $<--$ & Pridobiv & $-0,048$ & 0,577 \\
\hline ZadovoljNagrajevanj & $<--$ & Uporaba & 0,023 & 0,823 \\
\hline Usposobljenost & $<--$ & Prenos_A & 0,047 & 0,623 \\
\hline Usposobljenost & $<--$ & Vrst_A & $-0,079$ & 0,299 \\
\hline Usposobljenost & $<--$ & Vrst_B & 0,253 & 0,003 \\
\hline Usposobljenost & $<--$ & UporabaVrst & 0,371 & $* * *$ \\
\hline Usposobljenost & $<--$ & CasaVrst & 0,318 & $* * *$ \\
\hline Usposobljenost & $<--$ & Prenos_B & $-\mathrm{O}, \mathrm{II} 2$ & 0,230 \\
\hline Usposobljenost & $<--$ & Shranjev & $-0,076$ & 0,423 \\
\hline Usposobljenost & $<--$ & Pridobiv & 0,006 & 0,940 \\
\hline Usposobljenost & $<--$ & Uporaba & 0,162 & $0,08 \mathrm{I}$ \\
\hline
\end{tabular}

Legenda: ${ }^{* * *}-\mathrm{p}$ (stopnja značilnosti) je < 0,00 I.

Standardizirani regresijski koeficienti za opazovane spremenljivke so dokaj nizki, od najnižje vrednosti $-0,003$ do najvišje vrednosti 0,425 , in večinoma niso statistično značilni (preglednica IoI). To pomeni, da ne moremo z zanesljivostjo trditi, da ti vplivi obstajajo tudi v populaciji in ne le v vzorcu turističnih agencij. Vrednost RMSEA znaša o,209, kar pomeni, da je po tem merilu prilagajanje modela dobro, saj manjša absolutna vrednost tega kazalca pomeni boljše prilagajanje modela. Ostali indeksi $(\mathrm{CFI}=0,648, \mathrm{NFI}=0,634, \mathrm{RFI}=0,182)$ so razmeroma nizki. Na podlagi ugotovljenega lahko vseeno ocenjujemo, da je prilagajanje modela sprejemljivo (slika ıo). 
Strukturni model vpliva človeškega kapitala na uspešnost poslovanja Grafična ponazoritev celotnega strukturnega modela povezanosti človeškega kapitala in uspešnosti poslovanja prikazuje slika I I.

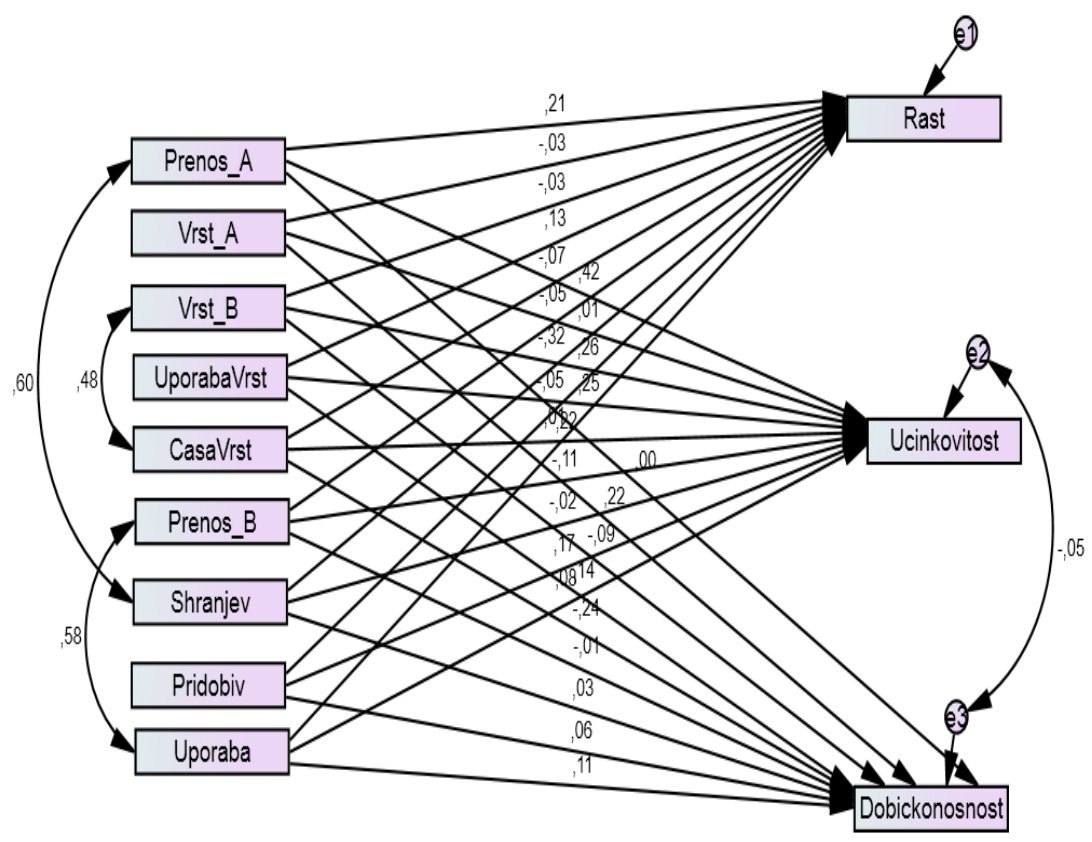

Slika i I: Strukturni model vpliva človeškega kapitala na uspešnost poslovanja

Hi-kvadrat $=236,769, \mathrm{df}=35, \mathrm{p}=0,000$

Opombe: Hi-kvadrat $/ \mathrm{df}=6,765, \mathrm{CFI}=43 \mathrm{I}, \mathrm{NFI}=0,437, \mathrm{RFI}=-0,06 \mathrm{I}, \mathrm{RMSEA}=0,237$,

PCLOSE $=0,000$.

Legenda: e I...e 3 = faktorji napake.

Iz slike I I vidimo, da je model vseboval 9 opazovanih spremenljivk $s$ področja človeškega kapitala (prenos znanja - nestimulativni, izobraževanje - trženje, izobraževanja - komuniciranje, uporaba znanja na lastnih izkušnjah, čas izobraževanja, prenos znanja - timski, shranjevanje znanja in pridobivanje znanja) in 3 opazovane spremenljivke s področja uspešnosti poslovanja (rast, donosnost in dobičkonosnost TA).

V celotnem strukturnem modelu je tako sodelovalo I2 opazovanih spremenljivk. Povezanost med spremenljivkami konstrukta človeški kapital in spremenljivkami konstrukta uspešnost poslovanja je enostranska in poteka v smeri od konstrukta človeški kapital h konstruktu uspešnost poslovanja (slika II). 
V preglednici IO2 so prikazani standardizirani regresijski koeficienti in njihove statistične značilnosti za strukturni model vpliva človeškega kapitala na uspešnost poslovanja.

Preglednica I02: Standardizirani regresijski koeficienti in njihove statistične značilnosti za strukturni model vpliva človeškega kapitala na uspešnost poslovanja

\begin{tabular}{|c|c|c|c|c|}
\hline $\begin{array}{l}\text { Spremenljivke uspešnos- } \\
\text { ti poslovanja }\end{array}$ & Smer vpliva & $\begin{array}{l}\text { Spremenljivke } \\
\text { cloveškega kapitala }\end{array}$ & $\begin{array}{l}\text { Standardiziran re- } \\
\text { gresijski koeficient }\end{array}$ & $\begin{array}{l}\text { Statistična značil- } \\
\operatorname{nost}(\mathbf{p})\end{array}$ \\
\hline Rast & $<--$ & Prenos_A & 0,208 & 0,075 \\
\hline Rast & $<--$ & Vrst_A & $-0,028$ & $0,76 \mathrm{I}$ \\
\hline Rast & $<--$ & Vrst_B & $-0,034$ & 0,751 \\
\hline Rast & $<--$ & UporabaVrst & 0,128 & 0,173 \\
\hline Rast & $<--$ & CasaVrst & $-0,074$ & 0,488 \\
\hline Rast & $<--$ & Prenos_B & $-0,054$ & 0,637 \\
\hline Rast & $<--$ & Shranjev & $-0,319$ & 0,006 \\
\hline Rast & $<--$ & Pridobiv & $-0,050$ & 0,596 \\
\hline Rast & $<--$ & Uporaba & 0,007 & 0,954 \\
\hline Donosnost & $<--$ & Prenos_A & 0,421 & $* *$ \\
\hline Donosnost & $<--$ & Vrst_A & 0,010 & 0,902 \\
\hline Donosnost & $<--$ & Vrst_B & 0,262 & 0,005 \\
\hline Donosnost & $<--$ & UporabaVrst & 0,246 & 0,002 \\
\hline Donosnost & $<--$ & CasaVrst & $-0,219$ & 0,017 \\
\hline Donosnost & $<--$ & Prenos_B & $-0,105$ & 0,288 \\
\hline Donosnost & $<--$ & Shranjev & $-0,023$ & 0,819 \\
\hline Donosnost & $<--$ & Pridobiv & 0,170 & 0,036 \\
\hline Donosnost & $<--$ & Uporaba & 0,075 & 0,448 \\
\hline Dobičkonosnost TA & $<--$ & Prenos_A & $-0,004$ & 0,972 \\
\hline Dobičkonosnost TA & $<--$ & Vrst_A & 0,223 & 0,013 \\
\hline Dobičkonosnost TA & $<--$ & Vrst_B & $-0,093$ & 0,361 \\
\hline Dobičkonosnost TA & $<--$ & CasaVrst & $-0,239$ & o,019 \\
\hline Dobičkonosnost TA & $<--$ & UporabaVrst & 0,138 & 0,125 \\
\hline Dobičkonosnost TA & $<--$ & Prenos_B & $-0,009$ & 0,931 \\
\hline Dobičkonosnost TA & $<--$ & Shranjev & 0,025 & 0,821 \\
\hline Dobičkonosnost TA & $<--$ & Pridobiv & 0,059 & 0,512 \\
\hline Dobičkonosnost TA & $<--$ & Uporaba & $0, \mathrm{III}$ & 0,309 \\
\hline
\end{tabular}

Legenda: ${ }^{* * *}-\mathrm{p}$ (stopnja značilnosti) je < 0,00I. 
Standardizirani regresijski koeficienti za opazovane spremenljivke so dokaj nizki, od najnižje vrednosti -0,004 do najvišje vrednosti $0,42 \mathrm{I}$, in večinoma niso statistično značilni (preglednica I02). To pomeni, da ne moremo z zanesljivostjo trditi, da ti vplivi obstajajo tudi v celotni populaciji, ki je predstavljala naš vzorec.

Vrednost RMSEA znaša 0,237 , kar pomeni, da je po tem merilu prilagajanje modela dobro, saj manjša absolutna vrednost tega kazalca pomeni boljše prilagajanje modela.

Indeksa CFI $=43 \mathrm{I}$ in NFI $=0,437$ sta srednje visoka, medtem ko je indeks RFI $=-0,06 \mathrm{I}$ razmeroma nizek. Na podlagi ugotovljenega lahko vseeno ocenimo, da je prilagajanje modela sprejemljivo (slika I I).

\section{Strukturni model vpliva organizacijske klime na uspešnost poslovanja}

Ponazoritev celotnega strukturnega modela povezanosti organizacijske klime in uspešnosti poslovanja (slika I2) prikazuje, da je model vseboval 6 opazovanih spremenljivk s področja organizacijske klime (notranji odnosi, vodenje (delegiranje dela), pripadnost organizaciji, razvoj kariere, zadovoljstvo zaposlenih in nagrajevanje ter strokovna usposobljenost in učenje) in 3 opazovane spremenljivke s področja uspešnosti poslovanja (rast, donosnost in dobičkonosnost TA).

V celotnem strukturnem modelu je tako sodelovalo 9 opazovanih spremenljivk. Povezanost med spremenljivkami konstrukta organizacijska klima in spremenljivkami konstrukta uspešnost poslovanja je enostranska in poteka $\mathrm{v}$ smeri od konstrukta organizacijska klima h konstruktu uspešnost poslovanja (slika I2).

Standardizirani regresijski koeficienti na opazovane spremenljivke so dokaj nizki, od najnižje vrednosti $-0,270$ do najvišje vrednosti 0,393 in so večinoma statistično značilni (preglednica Ioo). To pomeni, da lahko z zanesljivostjo trdimo, da ti vplivi obstajajo tudi v celotni populaciji, ki je bila naš vzorec.

Vrednost RMSEA znaša 0,237 , kar pomeni, da je po tem merilu prilagajanje modela dobro, saj manjša absolutna vrednost tega kazalca pomeni boljše prilagajanje modela.

Indeksa CFI $=0,560$ in NFI $=0,559$ sta srednje visoka, medtem ko je indeks RFI $=-0,008$ razmeroma nizek. Na podlagi ugotovljenega lahko vseeno ocenjujemo, da je prilagajanje modela sprejemljivo (slika I2). 


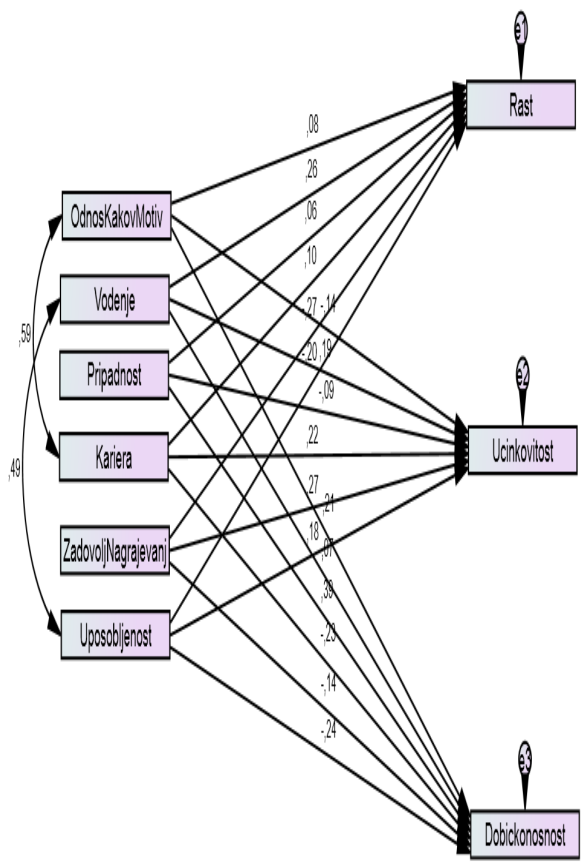

Slika I2: Strukturni model vpliva organizacijske klime na uspešnost poslovanja

Hi-kvadrat $=108,939, \mathrm{df}=16, \mathrm{p}=0,000$

Opombe: $\mathrm{Hi}$-kvadrat $/ \mathrm{df}=6,809, \mathrm{CFI}=0,560, \mathrm{NFI}=0,559, \mathrm{RFI}=-0,008, \mathrm{RMSEA}=0,237$,

PCLOSE $=0,000$.

Legenda: e 1...e 3 = faktorji napake.

V preglednici I03 so prikazani standardizirani regresijski koeficienti in njihove statistične značilnosti za strukturni model vpliva človeškega kapitala na uspešnost poslovanja.

Preglednica 103: Standardizirani regresijski koeficienti in njihove statistične značilnosti za strukturni model vpliva organizacijske klime na uspešnost poslovanja

\begin{tabular}{|c|c|c|c|c|}
\hline $\begin{array}{l}\text { Spremenljivke us- } \\
\text { pešnosti poslovanja }\end{array}$ & Smer vpliva & $\begin{array}{l}\text { Spremenljivke or- } \\
\text { ganizacijske klime }\end{array}$ & $\begin{array}{c}\text { Standardiziran regresij } \\
\text { ski koeficient }\end{array}$ & $\begin{array}{c}\text { Statistična } \\
\text { značilnost }(\mathbf{p})\end{array}$ \\
\hline Rast & $<--$ & $\begin{array}{l}\text { ZadovoljNagra- } \\
\text { jevanj }\end{array}$ & $-0,270$ & 0,003 \\
\hline Rast & $<--$ & Kariera & 0,100 & 0,371 \\
\hline Rast & $<--$ & Pripadnost & 0,056 & 0,534 \\
\hline Rast & $<--$ & Vodenje & 0,263 & O,OII \\
\hline Rast & $<--$ & $\begin{array}{c}\text { OdnosKakovMo- } \\
\text { tiv }\end{array}$ & 0,075 & 0,500 \\
\hline
\end{tabular}




\begin{tabular}{|c|c|c|c|c|}
\hline $\begin{array}{l}\text { Spremenljivke us- } \\
\text { pešnosti poslovanja }\end{array}$ & Smer vpliva & $\begin{array}{l}\text { Spremenljivke or- } \\
\text { ganizacijske klime }\end{array}$ & $\begin{array}{c}\text { Standardiziran regresij } \\
\text { ski koeficient }\end{array}$ & $\begin{array}{c}\text { Statistična } \\
\text { značilnost }(\mathbf{p})\end{array}$ \\
\hline Donosnost & $<--$ & $\begin{array}{l}\text { OdnosKakovMo- } \\
\text { tiv }\end{array}$ & $-0,138$ & 0,202 \\
\hline Donosnost & $<--$ & Vodenje & 0,194 & 0,052 \\
\hline Donosnost & $<--$ & Pripadnost & $-0,093$ & 0,286 \\
\hline Donosnost & $<--$ & Kariera & 0,216 & 0,045 \\
\hline Donosnost & $<--$ & $\begin{array}{l}\text { ZadovoljNagra- } \\
\text { jevanj }\end{array}$ & 0,270 & 0,002 \\
\hline Donosnost & $<--$ & Usposobljenost & 0,178 & 0,076 \\
\hline Dobičkonosnost TA & $<--$ & $\begin{array}{l}\text { OdnosKakovMo- } \\
\text { tiv }\end{array}$ & 0,209 & 0,046 \\
\hline Dobičkonosnost TA & $<--$ & Vodenje & 0,065 & 0,503 \\
\hline Dobičkonosnost TA & $<--$ & Pripadnost & 0,393 & $* * *$ \\
\hline Dobičkonosnost TA & $<--$ & Kariera & $-0,233$ & 0,027 \\
\hline Dobičkonosnost TA & $<--$ & $\begin{array}{l}\text { ZadovoljNagra- } \\
\text { jevanj }\end{array}$ & $-0,137$ & 0,107 \\
\hline Dobičkonosnost TA & $<--$ & Usposobljenost & $-0,238$ & 0,014 \\
\hline Rast & $<--$ & Usposobljenost & $-0,200$ & 0,053 \\
\hline
\end{tabular}

Legenda: ${ }^{* *}-\mathrm{p}$ (stopnja značilnosti) je < o,oor.

\section{Celotni strukturni model vpliva človeškega kapitala in organizacijske klime na uspešnost poslovanja}

Ponazoritev celotnega strukturnega modela vpliva konstrukta človeški kapital in konstrukta organizacijska klima na uspešnost poslovanja TA kaže, da je model vseboval g opazovanih spremenljivk s področja človeškega kapitala (prenos znanja - nestimulativni, izobraževanje - trženje, izobraževanja - komuniciranje, uporaba znanja na lastnih izkušnjah, čas izobraževanj, prenos znanja - timski, shranjevanje znanja, pridobivanje znanja in uporaba znanja). Model je vseboval še 6 opazovanih spremenljivk s področja organizacijske klime (notranji odnosi, vodenje (delegiranje dela), pripadnost organizaciji, razvoj kariere, zadovoljstvo zaposlenih in nagrajevanje ter strokovna usposobljenost in učenje) in Io opazovanih spremenljivk s področja uspešnosti poslovanja (rast: prihodki od prodaje, povečanje stevila zaposlenih, povečanje tržnega deleža na domačem in tujem trgu in dobiček; donosnost: ROI, ROA, ROE ter dobičkonosnost TA: primerjava z dobičkom $z$ vsemi konkurenčnimi turističnimi agencijami/poslovalnicami in tudi v primerjavi sturisticnimi agencijami/poslovalnicami, ki so na trgu enako stevilo let in $v$ enaki fazi razvoja). 
$V$ celotnem strukturnem modelu je tako sodelovalo 25 opazovanih spremenljivk. Pri celotnem strukturnem modelu smo ugotovili, da je konstrukt pokazal visoko stopnjo zanesljivosti, saj smo že predhodno ugotovili, da so vse vrednosti Cronbachovega koeficienta $\alpha$ pri faktorjih, ki ga sestavljajo, visoki.

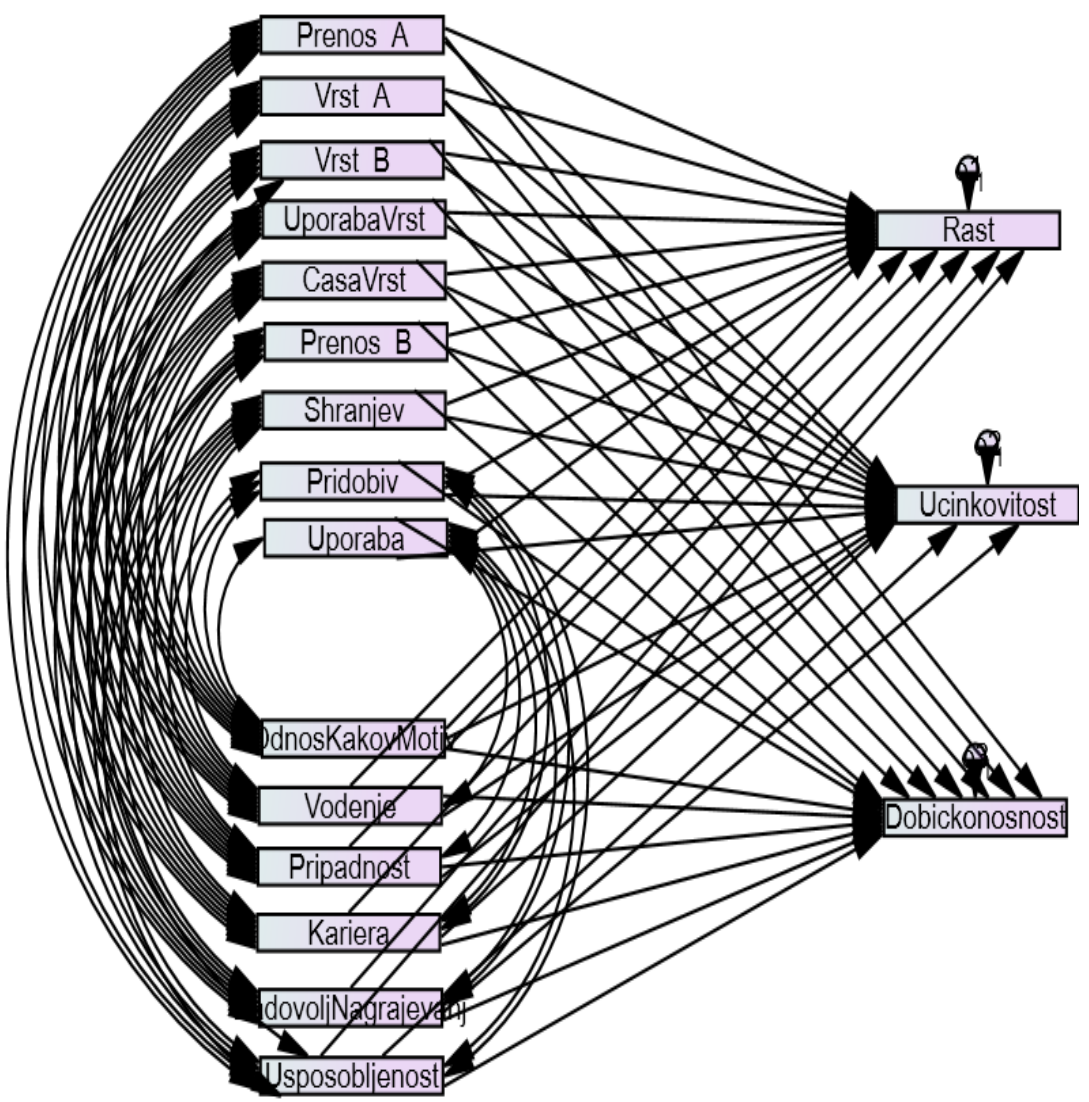

Slika I3: Celotni strukturni model povezanosti človeškega kapitala in organizacijske klime ter njunega vpliva na uspešnost poslovanja

Hi-kvadrat $=447,23 \mathrm{I}, \mathrm{df}=54, \mathrm{P}=0,000$

Opombe: $\mathrm{Hi}$-kvadrat $/ \mathrm{df}=8,282, \mathrm{CFI}=0,429, \mathrm{NFI}=0,469, \mathrm{RFI}=-0,489, \mathrm{RMSEA}=0,266$, PCLOSE $=0,000$.

Legenda: e 1... e $3=$ faktorji napake.

Povezanost med spremenljivkami konstrukta človeški kapital in konstrukta organizacijska klima je obojestranska. Povezanost med spremenljivkami konstrukta človeški kapital in spremenljivkami konstrukta 
uspešnost poslovanja je enostranska in poteka $\mathrm{v}$ smeri od konstrukta človeški kapital h konstruktu uspešnost poslovanja. Tudi povezanost med konstruktom organizacijska klima in konstruktom uspešnost poslovanja je enostranska in poteka $\mathrm{v}$ smeri od konstrukta organizacijska klima $\mathrm{h}$ konstruktu uspešnost poslovanja.

Celoten strukturni model povezanosti človeškega kapitala in organizacijske klime ter njunega vpliva na uspešnost poslovanja predstavljamo na sliki I3. Zaradi številnih povezav smo regresijske koeficiente zaokrožili na dve decimalni mesti in bi jih iz slike sicer težko razbrali, predstavili pa smo jih v preglednici 104 .

Standardizirani regresijski koeficienti za opazovane spremenljivke so dokaj nizki, od najnižje vrednosti -0,374 do najvišje vrednosti 0,579 , in večinoma niso statistično značilni (preglednica 104). To pomeni, da ne moremo z zanesljivostjo trditi, da ti vplivi obstajajo tudi na celotni populaciji, ki je predstavljala naš vzorec.

V preglednici IO4 so prikazani standardizirani regresijski koeficienti in njihove statistične značilnosti za konstrukte celotnega strukturnega modela vpliva človeškega kapitala in organizacijske klime na uspešnost poslovanja.

Preglednica I04: Standardizirani regresijski koeficienti in njihove statistične značilnosti za konstrukte celotnega strukturnega modela vpliva človeškega kapitala in organizacijske klime na uspešnost poslovanja

\begin{tabular}{|c|c|c|c|c|c|}
\hline Spremenljivka & Smer vpliva & Spremenljivka & St. reg. koef. * & $\begin{array}{l}\text { St. reg. koef. na } \\
\text { dve dec. št. }{ }^{*}\end{array}$ & $\begin{array}{c}\text { Stopnja } \\
\text { značilnosti }(p)\end{array}$ \\
\hline Rast & $<--$ & ZadovoljNagrajevanj & $-0,108$ & $-O, I I$ & 0,149 \\
\hline Rast & $<--$ & Kariera & 0,131 & 0,13 & 0,047 \\
\hline Rast & $<--$ & Pripadnost & 0,052 & 0,05 & 0,549 \\
\hline Rast & $<--$ & Vodenje & 0,347 & 0,35 & $* * *$ \\
\hline Rast & $<--$ & OdnosKakovMotiv & 0,128 & 0,13 & 0,330 \\
\hline Rast & $<--$ & Prenos_A & 0,074 & 0,07 & $\circ, \circ 8 \circ$ \\
\hline Rast & $<--$ & Vrst_A & ०,००8 & $0, \mathrm{OI}$ & $\circ, 88 \mathrm{I}$ \\
\hline Rast & $<--$ & Vrst_B & $-0,038$ & $-0,04$ & 0,466 \\
\hline Rast & $<--$ & UporabaVrst & 0,014 & $0,0 \mathrm{I}$ & $0,88 \circ$ \\
\hline Rast & $<--$ & CasaVrst & 0,062 & 0,06 & 0,414 \\
\hline Rast & $<--$ & Prenos_B & $-0,125$ & $-0,13$ & 0,094 \\
\hline Rast & $<--$ & Shranjev & $-0,163$ & $-0,16$ & 0,002 \\
\hline Rast & $<--$ & Pridobiv & 0,009 & o, OI & 0,854 \\
\hline
\end{tabular}




\begin{tabular}{|c|c|c|c|c|c|}
\hline Spremenljivka & Smer vpliva & Spremenljivka & St. reg. kocf. * & $\begin{array}{l}\text { St. reg. koef. na } \\
\text { dve dec. št. }{ }^{*}\end{array}$ & $\begin{array}{c}\text { Stopnja } \\
\text { značilnosti }(\mathbf{p})\end{array}$ \\
\hline Rast & $<--$ & Uporaba & $-0,161$ & $-0,16$ & 0,022 \\
\hline Donosnost & $<--$ & Prenos_A & 0,243 & 0,24 & $* * *$ \\
\hline Donosnost & $<--$ & Vrst_A & 0,006 & ০,OI & 0,926 \\
\hline Donosnost & $<--$ & Vrst_B & o,116 & 0,12 & 0,094 \\
\hline Donosnost & $<--$ & UporabaVrst & 0,207 & $0,2 \mathrm{I}$ & 0,085 \\
\hline Donosnost & $<--$ & CasaVrst & $-0,206$ & $-0,2 \mathrm{I}$ & 0,043 \\
\hline Donosnost & $<--$ & Prenos_B & $-0,145$ & $-0,15$ & 0,143 \\
\hline Donosnost & $<--$ & Shranjev & $-0,087$ & $-0,09$ & 0,208 \\
\hline Donosnost & $<--$ & Pridobiv & 0,183 & 0,18 & 0,007 \\
\hline Donosnost & $<--$ & Uporaba & 0,030 & 0,03 & 0,752 \\
\hline Donosnost & $<--$ & OdnosKakovMotiv & $-0,264$ & $-0,26$ & 0,132 \\
\hline Donosnost & $<--$ & Vodenje & 0,085 & 0,09 & $0,48 \mathrm{I}$ \\
\hline Donosnost & $<--$ & Pripadnost & $-0,042$ & $-0,04$ & 0,718 \\
\hline Donosnost & $<--$ & Kariera & 0,187 & 0,19 & 0,033 \\
\hline Donosnost & $<--$ & ZadovoljNagrajevanj & 0,236 & 0,24 & ০,०18 \\
\hline Donosnost & $<--$ & Usposobljenost & 0,103 & o,10 & $0,35 \mathrm{I}$ \\
\hline Dobičkonosnost TA & $<--$ & Prenos_A & 0,055 & 0,06 & 0,450 \\
\hline Dobičkonosnost TA & $<--$ & Vrst_A & 0,219 & 0,22 & 0,013 \\
\hline Dobičkonosnost TA & $<--$ & Vrst_B & $-0,004$ & 0,00 & 0,960 \\
\hline Dobičkonosnost TA & $<--$ & CasaVrst & $-0,17 \mathrm{I}$ & $-0,17$ & 0,191 \\
\hline Dobičkonosnost TA & $<--$ & UporabaVrst & 0,224 & 0,22 & 0,145 \\
\hline Dobičkonosnost TA & $<--$ & Prenos_B & $-0,034$ & $-0,03$ & 0,788 \\
\hline Dobičkonosnost TA & $<--$ & Shranjev & 0,050 & 0,05 & 0,577 \\
\hline Dobičkonosnost TA & $<--$ & Pridobiv & 0,047 & 0,05 & 0,584 \\
\hline Dobičkonosnost TA & $<--$ & Uporaba & 0,145 & 0,15 & 0,230 \\
\hline Dobičkonosnost TA & $<--$ & OdnosKakovMotiv & 0,319 & 0,32 & 0,156 \\
\hline Dobičkonosnost TA & $<--$ & Vodenje & 0,005 & $0,0 \mathrm{I}$ & 0,972 \\
\hline Dobičkonosnost TA & $<--$ & Pripadnost & 0,579 & 0,58 & $* *$ \\
\hline Dobičkonosnost TA & $<--$ & Kariera & $-0,337$ & $-0,34$ & 0,003 \\
\hline Dobičkonosnost TA & $<--$ & ZadovoljNagrajevanj & $-0,24 \mathrm{I}$ & $-0,24$ & 0,060 \\
\hline Dobičkonosnost TA & $<--$ & Usposobljenost & $-0,374$ & $-0,37$ & 0,008 \\
\hline Rast & $<--$ & Usposobljenost & $-0,151$ & $-0,15$ & 0,067 \\
\hline Prenos_A & $<-->$ & OdnosKakovMotiv & $-0,115$ & $-0,12$ & $* * *$ \\
\hline Vrst_A & $<-->$ & Vodenje & $-0,114$ & $-0, \mathrm{II}$ & 0,002 \\
\hline
\end{tabular}




\begin{tabular}{|c|c|c|c|c|c|}
\hline Spremenljivka & Smer vpliva & Spremenljivka & St. reg. koef. * & $\begin{array}{l}\text { St. reg. koef. na } \\
\text { dve dec. št. }{ }^{*}\end{array}$ & $\begin{array}{c}\text { Stopnja } \\
\text { značilnosti }(\mathbf{p})\end{array}$ \\
\hline OdnosKakovMotiv & $\langle->$ & Vrst_A & 0,010 & o,OI & 0,664 \\
\hline OdnosKakovMotiv & $<->$ & Vrst_B & $-0,032$ & $-0,03$ & 0,160 \\
\hline OdnosKakovMotiv & $<->$ & UporabaVrst & 0,005 & $0,0 \mathrm{I}$ & 0,7 \\
\hline OdnosKakovMotiv & $<->$ & CasaVrst & 0,077 & 0,08 & $* * *$ \\
\hline OdnosKakovMotiv & $<->$ & Prenos_B & 0,061 & 0,06 & $* * *$ \\
\hline OdnosKakovMotiv & $<->$ & Shranjev & $-0,088$ & $-0,09$ & $* * *$ \\
\hline OdnosKakovMotiv & $\langle->$ & Pridobiv & 0,063 & 0,06 & ०,OII \\
\hline OdnosKakovMotiv & $<->$ & Uporaba & 0,086 & 0,09 & $* * *$ \\
\hline Uporaba & $<->$ & Usposobljenost & o,OII & ०,OI & 0,678 \\
\hline Uporaba & $<->$ & ZadovoljNagrajevanj & $-0,103$ & $-0,10$ & 0,001 \\
\hline Uporaba & $\langle->$ & Kariera & 0,077 & 0,08 & 0,031 \\
\hline Uporaba & $<->$ & Pripadnost & 0,043 & 0,04 & 0,091 \\
\hline Vodenje & $<-->$ & Uporaba & 0,157 & 0,16 & $* * *$ \\
\hline Prenos_A & $<->$ & Vodenje & 0,117 & 0,12 & 0,009 \\
\hline Vodenje & $<->$ & Vrst_B & 0,106 & O,II & 0,003 \\
\hline Vodenje & $<->$ & UporabaVrst & 0,076 & 0,08 & $* * *$ \\
\hline Vodenje & $<-->$ & CasaVrst & $-0,149$ & $-0,15$ & $* * *$ \\
\hline Vodenje & $<-->$ & Prenos_B & 0,096 & 0,10 & $* * *$ \\
\hline Vodenje & $<->$ & Shranjev & $-0,014$ & $-0,0 \mathrm{I}$ & 0,69 \\
\hline Vodenje & $<->$ & Pridobiv & $-0,019$ & $-0,02$ & 0,574 \\
\hline Prenos_A & $<->$ & Pripadnost & $-0,154$ & $-0,15$ & $* * *$ \\
\hline Vrst_A & $<->$ & Pripadnost & 0,074 & 0,07 & 0,032 \\
\hline Vrst_B & $<->$ & Pripadnost & 0,007 & O,OI & 0,826 \\
\hline UporabaVrst & $<->$ & Pripadnost & 0,043 & 0,04 & 0,031 \\
\hline CasaVrst & $<->$ & Pripadnost & $-0,037$ & $-0,04$ & 0,128 \\
\hline Prenos_B & $<->$ & Pripadnost & $-0,038$ & $-0,04$ & O,II4 \\
\hline Shranjev & $<->$ & Pripadnost & 0,172 & 0,17 & $* * *$ \\
\hline Pridobiv & $<->$ & Pripadnost & $-0,027$ & $-0,03$ & 0,426 \\
\hline Pridobiv & $<->$ & Kariera & $-0,126$ & $-0,13$ & 0,012 \\
\hline Pridobiv & $<->$ & ZadovoljNagrajevanj & 0,024 & 0,02 & 0,539 \\
\hline Pridobiv & $\langle->$ & Usposobljenost & 0,013 & O,OI & 0,727 \\
\hline
\end{tabular}




\begin{tabular}{|c|c|c|c|c|c|}
\hline Spremenljivka & Smer vpliva & Spremenljivka & St. reg. koef. * & $\begin{array}{l}\text { St. reg. koef. na } \\
\text { dve dec. št. " }\end{array}$ & $\begin{array}{c}\text { Stopnja } \\
\text { značilnosti }(\mathbf{p})\end{array}$ \\
\hline Prenos_A & $<->$ & Kariera & 0,267 & 0,27 & $* * *$ \\
\hline Vrst_A & $<-->$ & Kariera & 0,134 & 0,13 & 0,006 \\
\hline Vrst_B & $<->$ & Kariera & $-0,005$ & $-\infty, 0 \mathrm{I}$ & 0,907 \\
\hline UporabaVrst & $<->$ & Kariera & 0,023 & 0,02 & 0,375 \\
\hline CasaVrst & $<->$ & Kariera & $-0,038$ & $-0,04$ & 0,255 \\
\hline Prenos_B & $<->$ & Kariera & $-0,022$ & $-0,02$ & 0,491 \\
\hline Shranjev & $\langle->$ & Kariera & 0,064 & 0,06 & 0,175 \\
\hline Shranjev & $<->$ & ZadovoljNagrajevanj & 0,098 & o,IO & 0,017 \\
\hline Prenos_B & $\langle->$ & ZadovoljNagrajevanj & 0,120 & 0,12 & $* * *$ \\
\hline CasaVrst & $<->$ & ZadovoljNagrajevanj & 0,052 & 0,05 & 0,065 \\
\hline UporabaVrst & $<->$ & ZadovoljNagrajevanj & ०,०19 & 0,02 & 0,386 \\
\hline Vrst_B & $<->$ & ZadovoljNagrajevan & 0,143 & 0,14 & $* * *$ \\
\hline Vrst_A & $<->$ & ZadovoljNagrajevanj & ০,OII & ०,OI & 0,767 \\
\hline Prenos_A & $<->$ & ZadovoljNagrajevanj & $-0,025$ & $-0,03$ & 0,598 \\
\hline Prenos_A & $<->$ & Usposobljenost & O,IO4 & 0,10 & 0,025 \\
\hline Vrst_A & $<->$ & Usposobljenost & $-0,006$ & $-0,0 \mathrm{I}$ & 0,001 \\
\hline UporabaVrst & $<->$ & Usposobljenost & 0,073 & 0,07 & ০,০০I \\
\hline CasaVrst & $<->$ & Usposobljenost & 0,192 & 0,19 & $* * *$ \\
\hline Shranjev & $<->$ & Usposobljenost & $-0,044$ & $-0,04$ & 0,233 \\
\hline Prenos_B & $<->$ & Usposobljenost & $-0,095$ & $-\mathrm{O}, \mathrm{IO}$ & $* * *$ \\
\hline Vrst_B & $\langle->$ & Usposobljenost & 0,091 & 0,09 & O,OI4 \\
\hline
\end{tabular}

Legenda: St. reg. koef. ${ }^{*}=$ standardiziran regresijski koeficient; St. reg. koef. na dve dec. št. ${ }^{* *}$ $=$ standardiziran regresijski koeficient (zaokrožen na dve decimalni številki); ${ }^{* *}-\mathrm{p}$ (stopnja značilnosti) je < 0,00 I.

Vrednost RMSEA znaša 0,266 , kar pomeni, da je po tem merilu prilagajanje modela dobro, saj manjša absolutna vrednost tega kazalca pomeni boljše prilagajanje modela.

Ostali indeksi (CFI $=0,429$, NFI $=0,469$, RFI $=-0,489)$ pa so razmeroma nizki. Na podlagi ugotovljenega lahko vseeno ocenjujemo, da je prilagajanje modela sprejemljivo (slika I3). 


\section{Povzetek ugotovitev raziskave}

Tu predstavljamo povzetek ugotovitev raziskave, prispevek $\mathrm{k}$ znanosti in stroki, implikacije in predloge za nadaljnje raziskovanje.

$\mathrm{Z}$ izpolnjevanjem namena in ciljev raziskave smo na osnovi opisnih statistik prišli po posameznih sklopih do naslednjih ugotovitev:

- Sociodemografske značilnosti anketirancev. Pri spletni anketi je glede na spol sodelovalo skoraj enako število žensk $(5 \mathrm{I}, 2 \%)$ in moških (48,8 \%). Največ anketirancev $(38,6 \%)$ je bilo starih nad 40 do 50 let, najmanj ( $8 \%$ ) pa do 30 let. Največ $(39,05 \%)$ je bilo zaposlenih na področju turizma nad to do 20 let, najmanj $(2,4 \%)$ pa nad 30 let, največ $(41,05 \%)$ je bilo zaposlenih v trenutni TA/ poslovalnici do ro let, najmanj ( $0,9 \%)$ pa nad 30 let. Glede na zaključeno stopnjo izobrazbe je bilo največ (43,65 \%) zaposlenih $\mathrm{z}$ visokošolsko ali univerzitetno izobrazbo, najmanj (5,55\%) pa s podiplomsko (magisterij, doktorat). Glede na vrsto zaposlitve je največ $(79,15 \%)$ zaposlenih za nedoločen čas s polnim delovnim časom, najmanj $(3,75 \%)$ pa za nedoločen čas s krajšim delovnim časom. Glede na funkcijo zaposlitve je največ $(34,4 \%)$ prodajalcev turističnih aranžmajev, najmanj $(1,3 \%)$ pa zaposlenih pod kategorijo drugo, kjer anketiranci niso navedli, za kakšno naravo dela gre.

- Značilnosti TA/poslovalnic. Glede na glavno dejavnost po SKD je največ (69\%) TA/poslovalnic, ki izvajajo dejavnost organizatorjev potovanj, najmanj $(2,7 \%)$ pa tistih, ki izvajajo dejavnost rezervacij in druge s potovanji povezane dejavnosti, skoraj vse 
imajo obe licenci, tako licenco za organiziranje turističnih aranžmajev kot tudi licenco za prodajo turističnih aranžmajev. Glede na organizacijski status je največ (81,75 \%) turističnih agencij, najmanj ( $1,95 \%)$ pa takšnih z drugim organizacijskim statusom, kjer anketiranci niso navedli, za kakšen organizacijski status gre. Glede na pravni status je največ $(76,75 \%)$ družb z omejeno odgovornostjo (d. o. o.), najmanj ( $0,7 \%)$ pa jih je v kategoriji drugo, kjer anketiranci niso odgovorili, za kakšen pravni status gre. TA se največ ukvarjajo s prodajo lastnih turističnih aranžmajev ( $51,7 \%)$, najmanjkrat pa so se anketiranci odločili za kategorijo drugo ( $1,52 \%)$, kjer niso navedli, za kakšno dejavnost gre. Po številu zaposlenih je največ $(48,7 \%)$ do 5 zaposlenih, najmanj (0,5\%) pa nad 250 zaposlenih. Glede na pokritost trga (domači, tuji trg) je največ $(74,5 \%)$ anketirancev odgovorilo, da gre za pokritost na domačem in tujem trgu, najmanj $(7,5 \%)$ pa, da gre za pokritost samo na tujem trgu. Glede na dejavnost (emitivni turizem, receptivni turizem) in glede na državljanstvo gostov se največ $(62,9 \%)$ ukvarjajo z emitivnim in receptivnim turizmom, najmanjkrat (o,7 \%) pa so se anketiranci odločili za kategorijo drugo, kjer niso navedli, za kakšno dejavnost gre.

- Cloveški kapital. Tu so anketiranci odgovarjali z določitvijo stopnje strinjanja $\mathrm{z}$ zapisanimi trditvami, in sicer od I (sploh se ne strinjam) do 5 (popolnoma se strinjam) za posamezno preučevano dimenzijo, kjer so največji in najmanjsi pomen pripisali pripisali posamezni spremenljivki s povprečno vrednostjo: pridobivanje znanja: največ $(4,62)$ - uporabljamo internet, najmanj $(3,77)$ - sodelujemo z zunanjimi raziskovalnimi institucijami; hranjevanje znanja: največ $(4,16)$ - shranjujemo znanje (imamo arhiv) o izvedbi in vsebini delovnih procesov, najmanj $(4, \mathrm{I})$ - shranjujemo zapise (imamo arhiv) o svojem nastanku, razvoju in viziji delovanja; prenos znanja: največ $(4,5)$ - dobro počutje v TA/poslovalnici pozitivno vpliva na prenos znanja, najmanj $(3,44)$ - zaposleni skrivamo svoje znanje pred sodelavci, ker menimo, da $s$ tem povečujemo svojo konkurenčno prednost pred njimi; uporaba znanja: največ $(4,3 \mathrm{I})$ - uspešno uporabljamo lastne izkušnje za razreševanje novih izzivov, najmanj (3,9I) - znanja med zaposlenimi je dovolj, problematična je le njegova uporaba; vrsta (način) izobraževanja: največ $(4,28)$ - informacije iščemo na internetu, najmanj $(3,33)$ - izobražujemo se na področju računovodstva; čas izobraževanja: največ $(4,38)$ - udeležujemo se enodnevnih oblik 
izobraževanj (tečaji, seminarji), najmanj $(4,12)$ - interno izobraževanje poteka znotraj delovnega časa.

- Organizacijska klima. Anketiranci so odgovarjali z določitvijo stopnje strinjanja $z$ zapisanimi trditvami, in sicer od I (sploh se ne strinjam) do 5 (popolnoma se strinjam) za posamezno preučevano dimenzijo, kjer so največji in najmanjši pomen pripisali posamezni spremenljivki s povprečno vrednostjo: odnos do kakovosti: največ $(4,69)$ - čutimo se odgovorne za kakovost svojega dela, najmanj $(4,46)$ - standard in cilj kakovosti sta jasna; inovativnost in iniciatiunost: največ $(4,58)$ - zavedamo se, da so izboljšave nujne, najmanj $(4,43)$ - delovne metode stalno izboljšujemo in posodabljamo; strokovna usposobljenost in učenje: največ $(4,36)$ - usposobljeni smo za svoje delo, najmanj $(4,22)$ - sistem za naše usposabljanje je dober; motivacija in zavzetost: največ $(4,6)$ - pripravljeni smo na dodaten napor, kadar je to potrebno, najmanj $(4,37)$ - dober delovni rezultat se hitro opazi in se pohvali; notranja komunikacija in informiranje: največ $(4,4)$ - sodelavci se med seboj pogovarjamo sproščeno, prijateljsko in enakopravno, najmanj $(4,13)$ - delovni sestanki so redni; vodenje (delegiranje) dela: največ $(4,53)$ - pri svojem delu smo samostojni, najmanj $(4,28)$ - nimamo ukazovalnega vodenja; notranji odnosi: največ $(4,44)-$ med sabo si zaupamo, najmanj $(4,37)$ - konflikte rešujemo v svojo korist; poznavanje poslanstva, vizije, ciljev: največ $(4,43)$ - cilje turistične agencije sprejemamo za svoje, najmanj $(4,19)$ - pri postavljanju ciljev poleg vodstva sodelujejo tudi drugi zaposleni; organiziranost dela: največ $(4,35)$ - zadolžitve so jasno opredeljene, najmanj $(4,2 \mathrm{I})$ - vodstvo sprejema odločitve pravočasno; pripadnost organizaciji: največ (4,5I) - zunaj turistične agencije pozitivno govorimo o njej, najmanj $(4,25)$ - zaposlitev je varna oz. zagotovljena; razvoj kariere: največ $(4, \mathrm{I} 3)$ - zadovoljni smo s sedanjim osebnim razvojem, najmanj $(3,99)$ - vodilni vzgajajo svoje naslednike; nagrajevanje glede na uspešnost: največ $(4,23)$ - uspešnost (doseganje nadpovprečnih delovnih rezultatov) se praviloma vrednoti po dogovorjenih ciljih in standardih, najmanj (4,04) tisti, ki smo bolj obremenjeni z delom, smo tudi ustrezno stimulirani; zadovoljstvo zaposlenih: največ $(4,3 \mathrm{I})$ - s sodelavci, najmanj $(3,22) \mathrm{z}$ višino plače.

- Uspešnost poslovanja v obdobju 20II-20I3 glede na obdobje 2008-2010 (na ta vpraśanja so odgovarjali le l/m/v TA/poslovalnic). Da so se prihodki od prodaje v drugem preučevanem obdob- 
ju (v nadaljevanju p/o) glede na prvo p/o zmanjšali, je odgovorilo $37,5 \% 1 / \mathrm{m} / \mathrm{v}$, da so se povečali, je odgovorilo $36,4 \% \mathrm{l} / \mathrm{m} / \mathrm{v}$, najmanj $(26, \mathrm{I} \%) \mathrm{l} / \mathrm{m} / \mathrm{v}$ pa je odgovorilo, da so ostali dokaj enaki. Prihodki od prodaje so se največ povečali in tudi največ zmanjšali za med ıo do $20 \%$, kar je odgovorilo i I, $4 \% 1 / \mathrm{m} / \mathrm{v}$, da pa so prihodki od prodaje ostali enaki, je odgovorilo $26 \% \mathrm{l} / \mathrm{m} / \mathrm{v}$. Da se je dobiček v drugem p/o glede na prvo p/o zmanjšal, je odgovorilo $42,5 \% 1 / \mathrm{m} / \mathrm{v}$, najmanj $1 / \mathrm{m} / \mathrm{v}$ (23\%), da je ostal enak, $34,5 \% 1 / \mathrm{m} / \mathrm{v}$ pa je odgovorilo, da se je dobiček povečal. Tistim l/m/v (ıо,3 \%), ki se jim je dobiček povečal, se je ta povečal nad to do $20 \%$, tistim l/m/v (I 4,9 \%), ki se jim je dobiček največ zmanjšal, pa se je ta zmanjšal nad $35 \%, 23 \% 1 / \mathrm{m} / \mathrm{v}$ pa je odgovorilo, da je dobiček ostal dokaj enak. Največ $1 / \mathrm{m} / \mathrm{v}(45,3 \%)$ je odgovorilo, da je dobičkonosnost $\mathrm{TA} /$ poslovalnice $\mathrm{v}$ primerjavi $\mathrm{z}$ vsemi konkurenčnimi TA v drugem p/o glede na prvo p/o približno enaka, najmanj $1 / \mathrm{m} / \mathrm{v}(4,7 \%)$ pa je odgovorilo, da je izjemno višja. Največ $1 / \mathrm{m} / \mathrm{v}(48,9 \%)$ je odgovorilo, da je dobičkonosnost TA/poslovalnice $\mathrm{v}$ primerjavi s TA, ki so na trgu enako število let in $\mathrm{v}$ enaki fazi razvoja, $v$ drugem $\mathrm{p} / \mathrm{o}$ glede na prvo $\mathrm{p} / \mathrm{o}$ približno enaka, najmanj $1 / \mathrm{m} / \mathrm{v}(3,5 \%)$ pa je odgovorilo, da je izjemno višja.

- Tržni delež na domačem in tujem trgu v obdobju $201 \mathrm{I}-2013$ glede na obdobje 2008-2010 (na ta vprašanja so odgovarjali le $\mathrm{l} / \mathrm{m} / \mathrm{v}$ TA/poslovalnic). Največ $(69,4 \%) \mathrm{l} / \mathrm{m} / \mathrm{v}$ je odgovorilo, da je tržni delež na domačem trgu v drugem p/o glede na prvo p/o ostal dokaj enak, $15,3 \% 1 / \mathrm{m} / \mathrm{v}$ je odgovorilo, da se je povečal, enak odstotek pa jih je odgovorilo, da se je zmanjšal. Kjer se je tržni delež na domačem trgu povečal $\mathrm{v}$ drugem $\mathrm{p} / \mathrm{o}$ glede na prvo $\mathrm{p} / \mathrm{o}$, je $8,2 \% \mathrm{l} / \mathrm{m} / \mathrm{v}$ odgovorilo, da se je največ povečal za do $5 \%$, kjer pa se je zmanjšal, je 4,8\% $1 / \mathrm{m} / \mathrm{v}$ odgovorilo, da se je največ zmanjšal za med 5 do ro \%, enak odstotek jih je odgovorilo, da se je največ zmanjšal za med ıo do $20 \%$. Največ $(74, \mathrm{r} \%) \mathrm{l} / \mathrm{m} / \mathrm{v}$ je odgovorilo, da je tržni delež na tujem trgu v drugem $\mathrm{p} /$ o glede na prvo p/o ostal dokaj enak, najmanj $1 / \mathrm{m} / \mathrm{v}(5,9 \%)$ je odgovorilo, da se je zmanjšal, $20 \% \mathrm{l} / \mathrm{m} / \mathrm{v}$ pa je odgovorilo, da se je povečal. Največ (ıо,5 \%) $1 / \mathrm{m} / \mathrm{v}$ je odgovorilo, da se je tržni delež na tujem trgu v drugem p/o glede na prvo $\mathrm{p} / \mathrm{o}$ povečal, in sicer za do $5 \%, \mathrm{I}, 2 \%$ $1 / \mathrm{m} / \mathrm{v}$ je odgovorilo, da se je zmanjšal za med 5 do $10 \%$, enako za med Io in $20 \%$ in tudi enako za nad $35 \%, 74, \mathrm{r} \% \mathrm{l} / \mathrm{m} / \mathrm{v}$ pa je odgovorilo, da je ostal dokaj enak. 
- Število zaposlenih v obdobju $20 \mathrm{II}-2013$ (na ta vprašanja so odgovarjali le $\mathrm{l} / \mathrm{m} / \mathrm{v}$ TA/poslovalnic). Največ ( $55,7 \%) \mathrm{l} / \mathrm{m} / \mathrm{v}$ je odgovorilo, da je število zaposlenih v p/o ostalo nespremenjeno, naj$\operatorname{manj}(\mathrm{r} 8,2 \%) \mathrm{l} / \mathrm{m} / \mathrm{v}$ je odgovorilo, da se je povečalo, $26, \mathrm{r} \% \mathrm{l} / \mathrm{m} / \mathrm{v}$ pa je odgovorilo, da se je zmanjšalo. Pri tistih $1 / \mathrm{m} / \mathrm{v}(6,8 \%)$, kjer se je $\mathrm{v}$ število zaposlenih povečalo, se je povečalo do $5 \%$, pri tistih $\left({ }_{1}, 6 \%\right) \mathrm{l} / \mathrm{m} / \mathrm{v}$, kjer se je zmanjšalo, se je zmanjšalo za med 5 in Io $\%, 55,7 \% \mathrm{l} / \mathrm{m} / \mathrm{v}$ pa je odgovorilo, da je število zaposlenih ostalo nespremenjeno.

- Zadovoljstvo $z$ donosnostjo v obdobju 20I I-20I3 (na to vprašanje so odgovarjali le $\mathrm{l} / \mathrm{m} / \mathrm{v}$ TA/poslovalnic, in sicer s kategorijami od I (najmanj) do 5 (največ) z izračunano povprečno vrednostjo). Največ $(3,87)$ jih je bilo zadovoljnih $\mathrm{z}$ razmerjem med dobičkom in trajnim kapitalom oz. med dolgoročnimi obveznostmi sredstev, najmanj $(3,58)$ pa z donosnostjo vloženih sredstev - gre za naložbe, ki so razmerje med dobičkom in sredstvi, vloženimi v naložbo.

- Merjenje učinkovitosti porabe znanja (na to vprašanje so odgovarjali le $\mathrm{l} / \mathrm{m} / \mathrm{v}$ TA/poslovalnic, in sicer $\mathrm{s}$ kategorijami od I (najmanj) do 5 (največ) z izračunano povprečno vrednostjo). Največ $(4,42)$ - učenje je dolžnost in pravica vseh zaposlenih, najmanj $(3,78)$ učinke uporabljenega znanja spremljamo z različnimi kazalniki.

$\mathrm{V}$ preglednici ros prikazujemo povzetek ugotovitev preverjanja hipotez.

Preglednica ı os: Povzetek ugotovitev preverjanja hipotez

\begin{tabular}{|c|c|c|c|}
\hline & $\begin{array}{c}\text { Spremenljivke - } \\
\text { statistično značilen } \\
\text { vpliv }\end{array}$ & Potrditev & Ugotovitev \\
\hline $\begin{array}{l}\text { HI } \\
\text { Med človeškim kapitalom in organizacijsko klimo v } \\
\text { turističnih agencijah obstaja pozitivna medsebojna po } \\
\text { vezava. }\end{array}$ & & & Delno potrjena \\
\hline $\begin{array}{l}\text { Hia } \\
\text { Med človeškim kapitalom in notranjimi odnosi kot } \\
\text { sestavino organizacijske klime obstaja pozitivna } \\
\text { medsebojna povezava. }\end{array}$ & Uporaba (+) & Delno & \\
\hline $\begin{array}{l}\text { Hıb } \\
\text { Med človeškim kapitalom in vodenjem (delegiranjem } \\
\text { dela) kot sestavino organizacijske klime obstaja pozitivna } \\
\text { medsebojna povezava. }\end{array}$ & $\begin{array}{c}\text { Vrst_A (-) } \\
\text { Vrst_B (+) } \\
\text { UporabaVrst (+) } \\
\text { CasaVrst (-) } \\
\text { Prenos_B (+) } \\
\text { Uporaba (+) }\end{array}$ & Zavrnjena & \\
\hline
\end{tabular}


HIC

Med človeškim kapitalom in pripadnostjo organizaciji kot sestavino organizacijske klime obstaja pozitivna UporabaVrst (+) Delno medsebojna povezava.

$\mathrm{H}_{\mathrm{IC}}$

Med človeškim kapitalom in razvojem kariere kot sestavino organizacijske klime obstaja pozitivna medsebojna povezava.

\section{Hid}

Med človeškim kapitalom ter zadovoljstvom zaposlenih in nagrajevanjem kot sestavino organizacijske klime obstaja pozitivna medsebojna povezava.

Vrst_B (+)
UporabaVrst (+) Delno
Shranjev (+)

\section{Hie}

Med človeškim kapitalom ter strokovno usposobljenostjo in učenjem kot sestavino organizacijske klime obstaja pozitivna medsebojna povezava.

$$
\text { Vrst_B (+) }
$$

UporabaVrst $(+)$

CasaVrst (+)

$\mathrm{H}_{2}$

Človeški kapital pozitivno vpliva na uspešnost oslovanja turističnih agencij.

Človeški kapital pozitivno vpliva na donosnost kot

\section{$\mathrm{H}_{2} \mathrm{~b}$}

Človeški kapital pozitivno vpliva na rast kot sestavino

Shranjev (-)

$\mathrm{Ne}$

uspešnosti poslovanja.

\section{$\mathrm{H}_{2} \mathrm{C}$}

Človeški kapital pozitivno vpliva na dobičkonosnost kot

Vrst_A (+)

$\mathrm{Ne}$ sestavino uspešnosti poslovanja.

$\mathrm{H}_{3}$

Organizacijska klima pozitivno vpliva na uspešnost poslovanja turističnih agencij.

\section{$\mathrm{H}_{3} \mathrm{a}$}

Organizacijska klima pozitivno vpliva na donosnost kot sestavino uspešnosti poslovanja.

\section{$\mathrm{H}_{3} \mathrm{~b}$}

Organizacijska klima pozitivno vpliva na rast kot estavino uspešnosti poslovanja.

\section{$\mathrm{H}_{3} \mathrm{C}$}

Organizacijska klima pozitivno vpliva na dobičkonosnost kot sestavino uspešnosti poslovanja.

$\begin{array}{ll}\text { Vodenje }(+) & \text { Delno } \\ \text { Kariera }(+) & \end{array}$

Vodenje (+)

ZadovoljNagraje- $\quad \mathrm{Ne}$ vanje $(-)$

\section{Pripadnost (+)}

Kariera (-)

Usposobljenost (-)
$\mathrm{Ne}$ 


\section{Prispevek k znanosti in stroki}

Glavni prispevek raziskave je razvit in iz primarnih podatkov empirično preverjen konceptualni model, ki vključuje spremenljivke konstruktov človeški kapital, organizacijska klima in uspešnost poslovanja turističnih agencij.

Teoretični prispevek raziskave $\mathrm{k}$ znanosti in stroki se odraža $\mathrm{v}$ nadgradnji vsebin in ugotovitev izbranih tujih ter domačih raziskav s preučevanega področja z lastnimi ugotovitvami, izhajajočimi iz empiričnega dela raziskave.

Empirični prispevek raziskave $\mathrm{k}$ znanosti in stroki je izvirna empirična ugotovitev prve tovrstne raziskave v Sloveniji in tudi širše. Empirična ugotovitev izhaja iz primarnih podatkov, pridobljenih s pomočjo spletnega anketnega vprašalnika, ki smo ga poslali lastnikom/managerjem/ vodjem in drugim zaposlenim $\mathrm{v}$ turističnih agencijah ter njihovih poslovalnicah z licenco, ki opravljajo glavno dejavnost, opredeljeno pri ciljni populaciji in vzorčenju.

S kvantitativno lastno empirično analizo smo predstavili izvirni prispevek, kjer smo z znanimi statističnimi metodami, opredeljenimi pri metodah analiz podatkov in testiranj hipotez, najprej parcialno, po posameznih hipotezah in podhipotezah, analizirali vpliv dejavnikov človeškega kapitala in organizacijske klime na uspešnost poslovanja turističnih agencij. Z modeliranjem $z$ linearnimi strukturnimi enačbami smo analizirali odnose med več spremenljivkami, ki so izhajale iz naših hipotez in podhipotez.

Pri analizi je sodelovalo več lastnikov/managerjev/vodij in drugih zaposlenih $\mathrm{v}$ turističnih agencijah in njihovih poslovalnicah, kot smo pričakovali, da bo naš vzorec, zato si upamo podatke $\mathrm{z}$ veliko verjetnostjo posplošiti na celotno populacijo. 



\section{Implikacije}

V nadaljevanju predstavljamo ključne implikacije za posamezne konstrukte, ki smo jih preučevali.

\section{Konstrukt človeški kapital}

Človeški kapital danes predstavlja zelo veliko vrednost, ki je vedno ne moremo ovrednotiti v denarju, namenjati pa ji moramo čedalje večjo vlogo. Rezultati kažejo, da so za konstrukt človeški kapital najpomembnejše spremenljivke, ki jim morajo $1 / \mathrm{m} / \mathrm{v}$ in tudi drugi zaposleni posvečati veliko pozornost; te so: uporaba znanja, izobraževanje na področju trženja, izobraževanja s področja komuniciranja, uporaba znanja na lastnih izkušnjah, čas izobraževanj, prenos znanja - timski, shranjevanje znanja, prenos znanja - nestimulativni, pridobivanje znanja in uporaba znanja. Rezultati kažejo, da imajo navedene spremenljivke človeškega kapitala izmed vseh preučevanih spremenljivk $\mathrm{v}$ spletnem anketnem vprašalni$\mathrm{ku}$ največji pomen. $\mathrm{L} / \mathrm{m} / \mathrm{v}$ in drugim zaposlenim $\mathrm{v}$ turističnih agencijah in njihovih poslovalnicah priporočamo, da si poleg formalne izobrazbe $\mathrm{z}$ določenega področja pridobijo še različna znanja z neformalnim izobraževanjem, pri tem pa so lahko pozorni tudi na številne ponudbe različnih svetovalnih, zaposlitvenih in drugih institucij, ki tudi brezplačno izvajajo številne delavnice, seminarje in usposabljanja z določenega področja, kar lahko prispeva h krepitvi posameznikovega človeškega kapitala; tudi turistične agencije s svojimi poslovalnicami morajo skrbeti za svoje zaposlene, kar mora biti v največji domeni l/m/v, ki morajo svoje znanje obnavljati in pridobivali nova znanja, potrebna za opravljanje svojega trenutnega dela in dela, ki ga bo narekovala prihodnost. 


\section{Konstrukt organizacijska klima}

Rezultati kažejo, da so najpomembnejše spremenljivke konstrukta organizacijska klima: notranji odnosi, vodenje (delegiranje dela), pripadnost organizaciji, razvoj kariere, zadovoljstvo zaposlenih in nagrajevanje ter strokovno usposabljanje in učenje. Navedene spremenljivke prispevajo $\mathrm{k}$ uspešnemu poslovanju turističnih agencij in njihovih poslovalnic. Zavedati se moramo, da so ljudje tisti, ki s svojim znanjem, veščinami, sposobnostmi in željo po dobri organizacijski klimi močno prispevajo $\mathrm{k}$ boljšemu poslovanju turističnih agencij in njihovih poslovalnic. Tudi $s$ področja organizacijske klime na trgu ponudniki nudijo številna izobraževanja, tudi brezplačno, in seveda se lahko $1 / \mathrm{m} / \mathrm{v}$ in d/z iz TA/poslovalnic tudi v bodoče udeležijo številnih izobraževanj s posameznega področja organizacijske klime in s tem usvojijo določen obseg znanj, ki jim bo lahko koristil za ohranjanje dobrih medsebojnih odnosov, krepil bodoče dobre medsebojne odnose in prispeval $\mathrm{k}$ boljši organizacijski klimi, $s$ čimer bodo posredno vplivali na uspešnost poslovanja turističnih agencij in njihovih poslovalnic.

\section{Konstrukt uspešnost poslovanja}

Rezultati raziskave kažejo, da so turistične agencije kljub turbulentnemu obdobju še vedno veliko pozornost namenjale rasti, predvsem prihodkom od prodaje, dobičku ter povečanju tržnega deleža na domačem in tujem trgu. Turistične agencije se nenehno primerjajo tudi z dobičkonosnostjo TA v primerjavi z vsemi konkurenčnimi turističnimi agencijami in tudi $s$ tistimi, ki so na trgu enako število let in v enaki fazi razvoja. Seveda pa je pomembna tudi donosnost, ki smo jo merili z ROI, ROA in ROE. Turistične agencije se zavedajo, da turistična dejavnost hitro raste, da se trgi enehno širijo in da se $\mathrm{z}$ razvojem turističnih destinacij ter $\mathrm{z}$ vsebinami, ki so pomembne za ta razvoj, tudi obisk turistov povečuje. Zato morajo turistične agencije poskrbeti, da bodo za turiste pripravile in jim nudile tiste storitve, ki bodo sestavljale primeren turistični proizvod, ki ga bodo turisti pripravljeni plačati po določeni ceni in ob primernih plačilnih pogojih, s čimer bodo agencije ustvarjale boljše in uspešnejše poslovanje na trgu. Za uspešnejše poslovanje na trgu bodo turistične agencije morale poskrbeti tudi s ponudbo, ki bo vključevala tudi le delne turistične proizvode, saj si v zadnjem obdobju številni turisti določene turistične storitve organizirajo že sami; prodaja klasičnih turističnih proizvodov, ki so bili značilni za drugo polovico prejšnjega stoletja in so v največji meri predstavljali pavšalno storitev, ki je običajno vključevala celoten turistični proizvod, so v veliki večini že preteklost. 


\section{Predlogi za nadaljnje raziskovanje}

Ugotovitve raziskave so lahko v pomoč drugim raziskovalcem pri nadaljnjem raziskovanju; ti bodo lahko na osnovi naših ugotovitev in dodatnih zbranih podatkov izvedli še dodatne analize, povezane z vplivom dejavnikov človeškega kapitala in organizacijske klime na uspešnost poslovanja turističnih agencij.

V prihodnje bi bilo zanimivo izvesti empirično raziskavo, ki bi vključevala tudi druge države Evropske unije, za začetek morda tiste države, ki geografsko mejijo na Slovenijo. Za pomoč pri raziskavi bi se lahko obrnili na tiste turistične agencije in njihove poslovalnice iz Slovenije, ki že imajo tržni delež v državah, ki bi jih vključili v raziskavo. Za pomoč bi se lahko obrnili na GZS, Zunanje ministrstvo RS, njihova predstavništva v tujini in druge institucije v tujini, pod okriljem katerih delujejo turistične agencije s svojimi poslovalnicami. Lahko bi raziskali, kakšen pomen $1 / \mathrm{m} / \mathrm{v}$ in drugi zaposleni v turističnih agencijah in njihovih poslovalnicah pripisujejo človeškemu kapitalu, organizacijski klimi in njunem vplivu na uspešnost poslovanja.

$\mathrm{Z}$ rezultati te raziskave bi bilo smiselno seznaniti izobraževalne institucije, ki se ukvarjajo z izobraževanjem na področju turizma in gostinstva, tako na srednješolski, višješolski, visokošolski (univerzitetni) in podiplomski ravni, saj bi tako rezultate lahko povezali, nadgradili s podobnimi raziskavami, zlasti s področja investicij v človeški kapital in organizacijske klime, ki prispevata $k$ uspešnosti poslovanja turističnih agencij in tudi drugih dejavnosti, ki niso bile predmet našega raziskovanja. Z rezultati raziskave pa bi bilo smiselno seznaniti tudi vse turistične agencije in njihove poslovalnice v Sloveniji, ki so predstavljale ciljno populaci- 
jo naše raziskave, predstavitev izsledkov raziskave pa bi bilo smiselno posredovati tudi tistim turističnim agencijam in njihovim poslovalnicam, ki niso sodile $\mathrm{v}$ našo ciljno populacijo.

Raziskava je bila usmerjena $\mathrm{v} / \mathrm{m} / \mathrm{v}$ turističnih agencij in njihovih poslovalnicah in tudi v druge zaposlene, tako da njeni rezultati ne predstavljajo samo ocene $1 / \mathrm{m} / \mathrm{v}$ turističnih agencijah in njihovih poslovalnicah, ampak tudi oceno drugih zaposlenih, ki bistveno prispevajo k uspešnosti poslovanja. $\mathrm{Z}$ uradnimi podatki na spletni strani bizi.si smo odgovore, ki se nanašajo na prihodke od prodaje, dobiček in število zaposlenih $\mathrm{v}$ turističnih agencijah in njihovih poslovalnicah, ki so jih na našo željo posredovali le $1 / \mathrm{m} / \mathrm{v}$ turističnih agencij in njihovih poslovalnic, primerjali tudi $\mathrm{z}$ odgovori $\mathrm{v}$ anketnem vprašalniku in rezultate naše raziskave predstavili. 


\section{Povzetek}

Raziskava obravnava vpliv dejavnikov človeškega kapitala in organizacijske klime na uspešnost poslovanja turističnih agencij in njihovih poslovalnic v Sloveniji. Glede na slovensko klasifikacijo dejavnosti je glavna dejavnost slednjih organiziranje potovanj ali rezervacij in drugih s potovanji povezanih dejavnosti. Empirični del raziskave temelji na analizi pisnih anketnih vprašalnikov na osnovi vzorca IO3 turističnih agencij in njihovih poslovalnic, kjer je sodelovalo 336 anketirancev, ki so bili glede na funkcijo zaposlitve lastniki/managerji/vodje in drugi zaposleni. $\mathrm{Z}$ anketnim vprašalnikom smo zbrali podatke $\mathrm{v}$ turističnih agencijah/poslovalnicah. $Z$ zbranimi podatki smo izvedli kvantitativno analizo, $v$ kateri smo z uporabo posameznih statističnih metod preverili postavljene hipoteze $s$ podhipotezami, nato pa $\mathrm{z}$ modeliranjem $\mathrm{z}$ linearnimi strukturnimi enačbami analizirali odnose med več spremenljivkami, izhajajočimi iz hipotez in podhipotez.

»Opisne« statistike se nanašajo na socio-demografske značilnosti anketirancev po spolu in starosti, delovnih izkušnjah na področju turizma in zaključeno stopnjo izobrazbe, med katerimi jih je bilo največ z visokošolsko ali univerzitetno izobrazbo. Največ jih je bilo zaposlenih za nedoločen čas s polnim delovnim časom. Pomembna funkcija zaposlitve je prodaja turističnih aranžmajev.

Glavna dejavnost večine turističnih agencij/poslovalnic je organiziranje potovanj, najmanj pa se jih ukvarja z dejavnostjo rezervacij in drugimi s potovanji povezanimi dejavnostmi; skoraj vse imajo obe licenci, tako licenco za organiziranje turističnih aranžmajev kot tudi licenco za prodajo turističnih aranžmajev. Glede na organizacijski status jih je največ 
turističnih agencij. Glede na pravni status je največ družb z omejeno odgovornostjo. Turistične agencije/poslovalnice se največ ukvarjajo s prodajo lastnih turističnih aranžmajev. Po številu zaposlenih je največ do 5 zaposlenih, najmanj pa nad 250. Glede na pokritost trga (domači : tuji trg) je največ anketirancev odgovorilo, da gre za pokritost na domačem in tujem trgu, najmanj pa, da gre za pokritost samo na tujem trgu. Glede na dejavnost (emitivni turizem, receptivni turizem) in glede na državljanstvo gostov se največ ukvarjajo z emitivnim in receptivnim turizmom.

Pri človeškem kapitalu so anketiranci odgovarjali glede na stopnjo strinjanja z zapisanimi trditvami za posamezno preučevano dimenzijo, kjer so največji in najmanjši pomen pripisali posamezni spremenljivki: pri pridobivanju znanja največ uporabljajo internet, najmanj sodelujejo z zunanjimi raziskovalnimi institucijami; pri shranjevanju znanja največ shranjujejo znanje (imajo arhiv) o izvedbi in vsebini delovnih procesov, najmanj shranjujejo zapise (imajo arhiv) o svojem nastanku, razvoju in viziji delovanja; pri prenosu znanja največji pomen pripisujejo dobremu počutju v turistični agenciji/poslovalnici, ki pozitivno vpliva na prenos znanja, najmanj pogosto pa zaposleni skrivajo svoje znanje pred sodelavci, ker menijo, da s tem povečujejo svojo konkurenčno prednost pred njimi; pri uporabi znanja najuspešneje uporabljajo lastne izkušnje za razreševanje novih izzivov, najmanj pa velja, da je znanja med zaposlenimi dovolj, problematična je le njegova uporaba; pri vrsti (načinu) izobraževanja največ informacije iščejo na internetu, najmanj se izobražujejo na področju računovodstva; pri času izobraževanja se največ udeležujejo enodnevnih oblik izobraževanj (tečaji, seminarji), najmanj pogosto pa interno izobraževanje poteka znotraj delovnega časa.

Pri organizacijski klimi so anketiranci odgovarjali glede na stopnjo strinjanja z zapisanimi trditvami za posamezno preučevano dimenzijo, kjer so največji in najmanjši pomen pripisali posamezni spremenljivki: pri odnosu do kakovosti se največ čutijo odgovorne za kakovost svojega dela, najmanj pa za jasnost standardov in ciljev kakovosti; pri inovativnosti in iniciativnosti se najbolj zavedajo, da so izboljšave nujne, najmanj pa, da delovne metode stalno izboljšujejo in posodabljajo; pri strokovni usposobljenosti in učenju kot največ nastopa usposobljenost za svoje delo, kot najmanj pa, da je sistem za usposabljanje dober; pri motivaciji in zavzetosti kot največ nastopa, da so pripravljeni na dodaten napor, kadar je to potrebno, kot najmanj pa, da se dober delovni rezultat hitro opazi in se pohvali; pri notranji komunikaciji in informiranju kot največ nastopa, da se sodelavci med seboj pogovarjajo sproščeno, prijateljsko in enakopravno, kot najmanj pa, da so delovni sestanki redni; pri vodenju (delegiranu) 
dela kot največ nastopa, da pri svojem delu so samostojni, kot najmanj pa, da nimajo ukazovalnega vodenja; pri notranjih odnosih kot največ nastopa, da si med sabo zaupajo, kot najmanj pa, da konflikte rešujejo v svojo korist; pri poznavanju poslanstva, vizije, ciljev kot največ nastopa, da cilje turistične agencije sprejemajo za svoje, kot najmanj pa, da pri postavljanju ciljev poleg vodstva sodelujejo tudi drugi zaposleni; pri organiziranosti dela kot največ nastopa, da so zadolžitve jasno opredeljene, kot najmanj pa, da vodstvo sprejema odločitve pravočasno; pri pripadnosti organizaciji kot največ nastopa, da zunaj turistične agencije pozitivno govorijo o njej, kot najmanj pa, da je zaposlitev varna oziroma zagotovljena; pri razvoju kariere kot največ nastopa, da so zadovoljni s sedanjim osebnim razvojem, kot najmanj pa, da vodilni vzgajajo svoje naslednike; pri nagrajevanju glede na uspešnost kot največ nastopa, da se uspešnost (doseganje nadpovprečnih delovnih rezultatov) praviloma vrednoti po dogovorjenih ciljih in standardih, kot najmanj pa, da so tisti, ki so bolj obremenjeni z delom, tudi ustrezno stimulirani; pri zadovoljstvu zaposlenih kot največ nastopa zadovoljstvo s sodelavci, kot najmanj pa zadovoljstvo $\mathrm{z}$ višino plače.

Glede uspešnosti poslovanja v obdobju $201 \mathrm{I}-2013$ glede na obdobje 2008-2010 (na ta vprašanja so odgovarjali le lastniki in managerji v turističnih agencijah/poslovalnicah) so bili odgovori mešani: ali so se prihodki od prodaje, dobiček in dobičkonosnost zmanjšali in povečali, najmanj pa jih je odgovorilo, da so ostali dokaj enaki. Tržni delež na domačem in tujem trgu se najpogosteje ni bistveno spremenil. Podobno velja za število zaposlenih, ki je najpogosteje ostalo nespremenjeno. Glede zadovoljstva z donosnostjo jih je bilo največ zadovoljnih z razmerjem med dobičkom in trajnim kapitalom oziroma med dolgoročnimi obveznostmi sredstev, najmanj pa z donosnostjo vloženih sredstev, pri čemer gre za naložbe, ki so razmerje med dobičkom in sredstvi, vloženimi v naložbo. Glede merjenja učinkovitosti porabe znanja jih je največ odgovorilo, da je učenje dolžnost in pravica vseh zaposlenih, najmanj pa, da učinke uporabljenega znanja spremljajo $\mathrm{z}$ različnimi kazalniki.

$\mathrm{Z}$ raziskavo smo razvili strukturni model povezanosti človeškega kapitala in organizacijske klime ter njunega vpliva na uspešnost poslovanja. Strukturni model ponazarja povezanost človeškega kapitala in organizacijske klime z uspešnostjo poslovanja turističnih agencij/poslovalnic. Ugotavljamo, da obstaja povezanost med vključenimi spremenljivkami konstrukta človeški kapital in konstrukta organizacijska klima, prav tako pa tudi povezanost med spremenljivkami konstrukta človeški kapital in spremenljivkami konstrukta organizacijska klima ter uspešnostjo poslo- 
vanja. Pri tem je pomembno, da obstaja pozitivna medsebojna povezava v raziskavo vključenih spremenljivk konstrukta človeški kapital: prenos znanja, izobraževanje s področja trženja, izobraževanje s področja komuniciranja, uporaba znanja na lastnih izkušnjah, čas in vrsta izobraževanja, shranjevanje znanja, pridobivanje znanja, uporaba znanja in $\mathrm{v}$ raziskavo vključenih spremenljivk konstrukta organizacijska klima: notranji odnosi, vodenje (delegiranje) dela, pripadnost organizaciji, razvoj kariere, zadovoljstvo zaposlenih in nagrajevanje ter strokovno usposabljanje in učenje, kar smo delno potrdili s prvo testirano hipotezo. Človeški kapital pozitivno vpliva na uspešnost poslovanja, kjer smo pri konstruktu uspešnost poslovanja preučevali donosnost, rast in dobičkonosnost turističnih agencij/poslovalnic in druge hipoteze nismo povsem zavrnili. Tretje hipoteze, da organizacijska klima pozitivno vpliva na uspešnost poslovanja turističnih agencij, tudi nismo povsem zavrnili in tako smo lahko temeljno tezo - Dejavniki človeškega kapitala in organizacijske klime vpivajo na uspešnost poslovanja turističnih agencij/poslovalnic - delno potrdili, saj je ne moremo povsem zavrniti. Za lastnike/managerje/vodje in druge zaposlene $\mathrm{v}$ turističnih agencijah/poslovalnicah je tako pomembno, da $\mathrm{v}$ raziskavo vključenim spremenljivkam konstrukta človeški kapital in konstrukta organizacijska klima posvečajo posebno pozornost, saj se lahko na podlagi vzorca, ki je vključeval celotno populacijo turističnih agencij/poslovalnic, rezultati in ugotovitve z veliko verjetnostjo posplošijo na celotno populacijo, in tako lahko turistične agencije/poslovalnice, upoštevajoč navedene spremenljivke konstrukta človeški kapital in konstrukta organizacijska klima, prispevajo $\mathrm{k}$ uspešnemu poslovanju turističnih agencij/poslovalnic, ki je prikazan s konstruktom uspešnosti poslovanja.

Empirična kvantitativna raziskava prispeva rezultate in spoznanja, pomembne za uspešno poslovanje turističnih agencij/poslovalnic. Turistična panoga se $\mathrm{v}$ zadnjih letih hitro razvija in turistične agencije/poslovalnice sp poleg drugih deležnikov razvoja slovenskega turizma pomembne za razvoj turizma v Sloveniji - zato je treba dejavnikom človeškega kapitala in organizacijske klime posvečati posebno pozornost. 


\section{Summary}

This research explores the influence of human capital and organizational climate on business performance of travel agencies and their branch offices in Slovenia. According to the Slovenian classification of activities their main activity is organization of tourist arrangements or booking and other travel-related activities. The empirical part of the research is based on the analysis of the written questionnaire based on a sample of ${ }_{103}$ travel agencies and their offices, which were completed and answered by 336 respondents in function of owners/managers/heads of departments and other employees. With the survey questionnaire collected data from travel agencies/branch offices, we carried out a quantitative analysis in which we tested the hypotheses with sub-hypotheses using statistical methods, and then analysed the relationships between several variables arising from the hypotheses and sub-hypotheses by linear structural equation modelling.

Descriptive statistics refer to the socio-demographic characteristics of respondents by gender and age, work experience in tourism and completed level of education, most of them with a higher education or university degree. Most of the respondents were full-time permanent employees. Sales of tourist arrangements is an important employment activity.

With regard to the characteristics of travel agencies/branch offices by main activity, they were mostly carried out by the activity of organizing tourist arrangements and the least by the activity of reservations and other travel-related activities, almost all of them hold licenses, both a license for organizing tourist arrangements and a license for the sale of tourist arrangements. According to organizational status, most of them are 
travel agencies. By legal status, most of them are limited liability companies. Travel agencies/branch offices are mostly involved in selling their own travel arrangements. The number of employees is mostly up to 5 employees and less frequently more than 250 employees. In terms of market coverage (domestic vs. foreign market), the majority of respondents answered that their coverage was on the domestic and foreign market, and the least that it was coverage on the foreign market only. Depending on the activity (outbound/outgoing tourism, inbound/incoming tourism) and the citizenship of the guests, they mostly deal with both outbound/outgoing and inbound/incoming tourism.

With regard to human capital, the respondents answered according to the degree of agreement with the written statements for each studied dimension, where they attributed the most and the least importance to an individual variable: in acquiring knowledge, they use the Internet the most, cooperate with external research institutions the least; when storing knowledge, as the most they storage knowledge (they have an archive) about the execution and content of work processes, while the least they keep records about their creation, development and vision of operation; in the transfer of knowledge, the greatest importance is attached to the well-being in the travel agency/branch offices, which has a positive impact on the transfer of knowledge, and, least often, employees hide their knowledge from colleagues because they believe that this increases their competitive advantage over them; in using knowledge as the most successful, they use own experience to solve new challenges, but the least is valid that knowledge among employees is sufficient, only its use is problematic; in the type of education, they search the most information on the Internet, while the least of education was in accounting; during the education period, they mostly attend one-day forms of training (courses, seminars), and the least often internal education takes place within working hours.

The respondents answered regarding the organization climate according to the degree of agreement with the written statements for each studied dimension: the attitude towards quality as the most they feel responsible for the quality of their work, and the least that the standard and the quality objective are clear; innovation and initiative are the most aware of the need for improvement, while as the least that they are constantly improving and updating working methods; professional competence and learning as the most that they are qualified for their work, while the least that the system for training is good; motivation and commitment as the most that they are ready for the extra effort when necessary, while the least that a good work result is quickly noticed and praised; inter- 
nal communication and information as the most important for their colleagues to talk to each other in a relaxed, friendly and equal manner, and at the least for regular meetings; managing (delegation) of work as the most that they are independent in their work, and the least that they do not have command leadership; internal relations as the most trusting of one another, and the least that conflicts are resolved for their own benefit; knowledge of the mission, vision, goals as the most that the goals of the tourist agency are accepted as their own, and the least that in addition to the management other employees participate in setting goals; organization of work as the most that responsibilities are clearly defined, and the least that management makes decisions in a timely manner; belonging to the organization as the most to speak positively about it outside the tourist agency, and the least that the job is secure; career development as the most that they are comfortable with their current personal development, and the least that leaders raise their successors; rewarding in terms of performance as the most that performance (achieving above-average work results) is generally valued according to agreed goals and standards, and at least that those who are more burdened with work are also properly stimulated; employee satisfaction with colleagues as the most, and the least with the amount of salary.

In terms of business performance in the period $201 \mathrm{I}-2013$ versus the period 2008-2010 (these questions were answered only by owners and managers of travel agencies/branch offices), the answers were mixed about revenues from sales, profits and profitability whether they declined or increased, and the least frequently that they remained fairly the same. In most cases, the market share on the domestic and foreign markets has not changed significantly. The same applies to the number of employees, which most often remained unchanged. In terms of satisfaction with profitability, most of them were satisfied with the ratio between profit and fixed capital, or between long-term liabilities, and the least with the return on invested assets, with investments being the ratio between profit and assets invested. Regarding measuring the efficiency of knowledge use, the most frequent answer was that learning is the duty and right of all employees, and the least that the effects of the knowledge used are monitored by different indicators.

The research has developed a structural equation model of the relationship between human capital and organizational climate and their impact on business performance. The structural equation model illustrates the link between human capital and organizational climate with the performance of travel agencies/branch offices. The structural equation mo- 
del shows that there is a correlation between the included variables of the human capital construct and the organizational climate construct, as well as a correlation between the variables of the human capital construct and the variables of the organizational climate construct and business performance. It is important that there is a positive mutual causality in the study included variables of the human capital construct: knowledge transfer, marketing education, communication education, use of knowledge in one's own experience, time and type of education, knowledge storage, knowledge acquisition, use of knowledge, and in the research included variables of the organizational climate construct: internal relations, leadership (delegation) of work, belonging to the organization, career development, employee satisfaction and rewards and professional training and learning, which was partially confirmed by the first tested hypothesis. Human capital has a positive impact on business performance with the construct of business performance as the profitability, growth and profitability of travel agencies/branch offices, and we did not completely reject the second hypothesis. The third hypothesis that the organizational climate has a positive impact on the performance of travel agencies was not completely rejected, and thus the base thesis cannot be completely rejected, because the influence of factors of human capital and organizational climate on the business performance of travel agencies/ branch offices was partially confirmed. It is important for owners/managers/heads of departments and other employees of travel agencies/branch offices that they give special attention in the study included variables of the construct of human capital and the construct of the organizational climate, because based on a sample that included the entire population of travel agencies/branch offices, the results and findings can likely be generalized to the entire population, and thus the travel agencies/branch offices, taking into account the mentioned variables of the human capital construct and the organizational climate construct, they can contribute to the successful operation of the travel agencies/branch offices as shown by the business performance construct.

The empirical quantitative research contributes the results and findings that are relevant for the successful business operation of travel agencies/branch offices. The tourism industry has been developing rapidly in the recent years, and tourist agencies/branch offices, in addition to other stakeholders in the development of Slovenian tourism, they are very important for the development of tourism in Slovenia. Therefore, to human capital factors and organizational climate need to be given special attention. 


\section{Literatura}

Aaker, D. A., in G. S. Day. 1990. Marketing Research. New York: Wiley.

Ambrož, M. 2005. Sociologija turizma: izhodišča za proučevanje potovalnih kultur. Portorož: Turistica, visoka šola za turizem.

Antončič, B. 2000. »Intrapreneurship: Construct Refinement and Integrative Model Development.« Doktorska disertacija, Case Western Reserve University.

Armstrong, M. 1995. A Handbook of Management Techniques. London: Kogan Page.

Auer Antončič, J. 20I2. 》Osebnostne značilnosti podjetnikov, zadovoljstvo zaposlenih in rast podjetja.« Doktorska disertacija, Univerza na Primorskem.

Bahun, D., in E. Rojc. 2006. Človeški viri-kapital podjetja. Velenje: Pozoj.

Becker, G. 1964. Human Capital: A Theoretical and Empirical Analysis with Special Reference to Education. New York: National Bureau of Economic Resarch.

Bernik, M., J. Florjančič, J. Jesenko, M. Jesenko, B. Kavčič, J. Kovač, R. Lang, B. Lukežič, D. Mežnar, S. Muller, T. Steger in I. Winkler. 2000. Management $v$ tranzicijskih procesih. Maribor: Fakulteta za organizacijske vede.

Bevc, M. I991. Ekonomski pomen izobraževanja. Radovljica: Didakta.

Biloslavo, R. 2008. Fleksibilnost politike: presoja z uporabo mehkega semantičnega diferenciala. Koper: Fakulteta za management. 
Biro Praxis. 20 1 4. »Kaj je organizacijska klima?« http://www.biro-praxis.si/ kaj-je-organizacijska-klima.html.

Bojnec, Š., in Z. Kribel. 2006. Poslovanje potovalnih agencij preko interneta: rezultati raziskave: spletno trženje slovenskih potovalnih agencij. Koper: Univerza na Primorskem.

Bojnec, Š., Ž. Čepar, T. Kosi in B. Nastav. 2007. Ekonomika podjetja. Koper: Fakulteta za management.

Bontis, N., in A. Serenko. 2009. >Longitudinal Knowledge Strategising in a Long-Term Healthcare Organization.« International Journal of Technology Management 47 (I): 276-97.

Bradač Hojnik, B. 2009. »Značilnosti zunanjega izvajanja aktivnosti in njegova povezava $\mathrm{z}$ uspešnostjo poslovanja malih in srednje velikih podjetij v Sloveniji.« Doktorska disertacija, Univerza v Mariboru.

Branco, D‘oria. 2007. »Synthesis Report for Economic Analysis and Training Needs in Social Economies in Slovenia, Italy, Great Britain and Poland.« Pilot project EU TESES, GEA College, Ljubljana.

Brečko, D. 2005. »Razvitost kadrovske funkcije v Sloveniji.« Human Resource Management Magazin 2 (4): 74-77.

Brečko, D. 2006. Načrtovanje kariere kot dialog med organizacijo in posameznikom. Ljubljana: Planet GV.

Brezovec, A. 2000. Marketing v turizmu: izhodišča za razmišljanje in upravljanje. Portorož: Turistica, visoka šola za turizem.

Brown, D., K. Spillman, M.-Y. Lee in Y. T. Lu. 2014. »Factors Influencing Small Tourism Business Performance: The Case of Central Kentucky, United States.«Journal of Hospitality Marketing \& Management 23 (7): 768-89.

Bruch, H. 2006. »Organizacijska energija: kako jo sprostimo, ohranimo in se osredotočimo nanjo.«HRM 4 (4): 6-I I.

Buckley, E. 2000. »The Hidden Value of Intellectual Capital, the Industry Standard.« http://www.thestandard.com/articl.

Burkart, A. J., in S. Medlik. 1975. The Management of Tourism: A Selection of Readings. London: Heinemann.

Carnegie, D. 201 2. S komunikacijo do uspeha. Tržič: Učila International.

Carnegie, D. 2013. Postanite uspešen vodja. Tržič: Učila International.

Chatzkel, J. 1998. »Measuring and Valuing Intellectual Capital: From Knowledge Management to Knowledge Measurement.« http://www. tlainc.com/articlıo.htm. 
Cooper, C. 2012. Essentials of Tourism. London: Financial Times Prentice Hall.

Čelebič, T. 2001. »Regionalni pregled toka kapitala znanja: razmerje med izobraževanjem in ekonomskim razvojem.«Andragoška spoznanja 7 (3): I $8-25$.

Černetič, M. 2006. Management ekonomike izobraževanja. Kranj: Moderna organizacija.

Černetič, M. 2007. Management in sociologija organizacij. Kranj: Moderna organizacija.

Daum, J. H. 2003. »Report from the First PMA Intellectual Capital Research Symposium, ${ }^{\text {st }}-2^{\text {nd }}$ October 2003. $\ll$ The New Economy Analyst Report, Cranfield. http://www.juergendaum.com/news/10_04_2003.htm.

Delaney, J. T., in M. A. Huselid. 1996. »The Impact of Human Resource Management Practices on Perceptions of Organizational Performance.« Academy of Management Journal 39 (4): 949-69.

Dermol, V. 2oro. Vplivi usposabljanj na učenje v podjetju in na njegovo uspešnost. Celje: Mednarodna fakulteta za družbene in poslovne študije.

Dimovski, V., S. Penger, J. Peterlin, M. Uhan, M. Černe in M. Marič. 2013. Napredni management. Ljubljana: Ekonomska fakulteta.

Dimovski, V., S. Penger, M. Škerlavaj in J. Žnidaršič. 2005. Učeča se organizacija: ustvarite podjetje znanja. Ljubljana: Gospodarski vestnik.

Drnovšek, M. 2002. »Merjenje prispevka podjetniških inovacij k rasti v mladih in tehnoloških podjetjih.« Doktorska disertacija, Univerza v Ljubljani.

Eccles, J. S., in A. Wigfield. 2002. »Motivational Beliefs, Values, and Goals.« Annual Review of Psychology 53 (I): 109-32.

Fatur, P., in B. Likar. 2009. Ustvarjalnost zaposlenih za inovativnost podjetja: sistemski vidiki managementa idej kot gradnika uspernne organizacije. Koper: Fakulteta za management.

Ferligoj, A. 2004. »Študijsko gradivo za predmet Multivariatna analiza 2004/2005.« Fakulteta za družbene vede, Ljubljana.

Field, A. 2006. Discovering Statistics Using SPSS. London: Sage.

Findeisen, D. 2004. »Kako do znanja v ekonomiji znanja: razmišljanje ob branju.« Andragoška spoznanja Io (I): 66-69.

Florjančič, J., in J. Jesenko. 1997. Management v turizmu. Kranj: Moderna organizacija.

Garcia-Morales, V. J., M. M. Jimenez-Barrionuevo in L. Gutierrez-Gutierrez. 20I0. »Transformational Leadership Influence on Organizational 
Performance through Organizational Learning and Innovation.«Journal of Business Research 65 (7): 1040-50.

Garvin, D. A. I993. »Building a Learning Organization.«Harvard Business Review 74 (4): 78-91.

Gomezelj Omerzel, D. 2008. »Model znanja v podjetništvu in vpliv znanja na poslovno uspešnost podjetja.« Doktorska disertacija, Univerza na Primorskem.

Gomezelj Omerzel, D. 2009. Management znanja v majhnih in srednjih podjetjih. Koper: Fakulteta za management.

Hair, J. F., W. C. Black, B. J. Babin in R. E. Anderson. 2006. Multivariate Data Analysis. New Jersey: Pearson Prentice Hall.

Hair, J. F., W. C. Black, B. J. Babin in R. E. Anderson. 2009. Multivariate Data Analysis. New Jersey: Pearson Prentice Hall.

Hu, M.-L. M., J.-S. Horng in Y.-H. C. Sun. 2008. »Hospitality Teams: Knowledge Sharing and Service Innovation Performance.« Tourism Management 30 (I): 4I-50.

Hudson, W. J. I993. How to Build It, Enhance It, Use It. New York: Wiley.

Ivankovič, G., in M. Jerman. 2000. Merjenje uspešnosti poslovanja v hotelirstvu. Portorož: Turistica, fakulteta za turistične študije.

Ivanuša-Bezjak, M. 1996. O podjetništvu: kaj moram vedeti o podjetništvu. Ljubljana: Gospodarski vestnik.

Ivanuša-Bezjak, M. 2006. »Iščemo kompetence!« Podjetnik Is (4): 44-45 in 85 .

Jelenc, Z. 1998. Vloga in razvoj Andragoškega društva Slovenije v obdobju 1968-1991. Ljubljana: Andragoški center Republike Slovenije, Andragoško društvo Slovenije.

Jones, J. E., in W. K. Bearley. 1995. Surveying Employees: A Practical Guidebook. Amherst: HRD Press.

Kaluža, V. 2006. »Možnosti razvoja podjetništva v turizmu.« Magistrsko delo, Univerza v Ljubljani.

Kaluža, V. 2012. Modul: svetovanje in prodaja turističnih proizvodov. Učbenik, dodatno gradivo po predavanjih za program Gastronomija in turizem SSI, smer: Turizem. Ljubljana: Center za dopisno izobraževanje Univerzum.

Kaluža, V. 20ıза. Možnosti razvoja v turizmu. Kočevje: samozaložba.

Kaluža, V. 201 b. Izobraževanje kot konkurenčna prednost Slovenije. Kočevje: samozaložba. 
Khan, M. A., M. D. Olsen in V. Turgut. 1993. Encyclopaedia of Hospitality and Tourism. New York: Van Nostrand Reinhold; London: Chapman \& Hall.

Kim, J. O., in C. W. Mueller. 1987. Introduction to Factor Analysis. London: Sage.

Klaneček, A. 20ıо. Integrativni model lastništva zaposlenih. Ljubljana: Maratonec.

Kostanjevec, B., in D. Gomezelj Omerzel. 2013. Podjetniška usmerjenost v družinskih podjetjih. Koper: Fakulteta za management.

Kovač, D., in A. Bertoncelj. 2007. »Model merjenja podjetniškega potenciala z menedžerskimi kompetencami.« Organizacija 40 (4): 98-103.

Kožuh, B., in J. Vogrinc. 2009. Obdelava podatkov. Ljubljana: Filozofska fakulteta.

Krajnc, A. 1982. Motivacija za izobraževanje. Ljubljana: Delavska enotnost.

Krajnc, A. 1997. Izobraževanje naša družbena vrednota. Ljubljana: Delavska enotnost.

Krašna, T. 2002. »Trženje v turizmu.« Študijsko gradivo za interno uporabo, Višja strokovna šola za gostinstvo in turizem, Bled.

Krašna, T. 2006. »Poslovanje turističnih in gostinskih podjetij.« Študijsko gradivo za interno uporabo, Višja strokovna šola za gostinstvo in turizem, Bled.

Laval, C. 2005 . Šola ni podjetje: neoliberalni napad na javno šolstvo. Ljubljana: Krtina.

Lawler, E. E., in S. A. Mohram. 2003. Creating a Strategic Human Resources Organization: An Assessment of Trends and New Directions. Stanford: Stanford University Press, Center for Effective Organizations.

Likar, B., J. Demšar, P. Fatur, D. Križaj, V. Pečjak, S. Sitar, D. Trček in N. Trunk Širca. 2000. Inovativnost za mlade. Ljubljana: Korona plus, Zveza prijateljev mladine Slovenije; Koper: Visoka šola za management.

Lipičnik, B. 1994. Ljudje in njihove zmožnosti. Ljubljana: Ekonomska fakulteta.

Lipičnik, B. 1998. Ravnanje z ljudmi pri delu. Ljubljana: Gospodarski vestnik.

Lumpkin, G. T., in G. G. Dess. 1996. »Clarifying Entrepreneurial Orientation Construct and Linking It to Performance.« Academy of Management Review 2 I (I): 135-72. 
Malačič, J. 200I. »Statistično ugotavljanje obsega človeškega kapitala.« V Novo tisočletje - pripravljenost statistike na razumevanje in merjenje pojavov: zbornik, ur. B. Tkačik, 424-36. Ljubljana: Statistični urad RS.

Markič, M. 2004. Inoviranje procesov: pogoj za odličnost poslovanja. Koper: Fakulteta za management.

Medlick, S. 1997. Dictionary of Travel, Tourism and Hospitality. Oxford: Butterworth Heinemann.

Meško Štok, Z. 2009. Management znanja v sodobnih organizacijah. Koper: Fakulteta za management.

Miglič, G. 1998. »Akcijsko učenje kot pristop k izpopolnjevanju in usposabljanju vodilnih in vodstvenih delavcev v državni upravi.« Magistrsko delo, Univerza v Ljubljani.

Miglič, G., in G. Vukovič. 2006. Spretnosti vodenja in sporazumevanja. Ljubljana: Ministrstvo za javno upravo, Direktorat za organizacijo in kadre, Upravna akademija.

Mihalič, R. 2007. Upravljajmo organizacijsko kulturo in klimo. Škofja Loka: Mihalič in partner.

Mihalič, T. 1997. Turistična podjetja: poslovanje in ekonomika turističnih agencij in gostinskih podjetij. Ljubljana: Ekonomska fakulteta.

Mihalič, T. 1999. Poslovanje in ekonomika turističnih podjetij. Ljubljana: Ekonomska fakulteta.

Mihalič, T. 2000. »Izbor gradiva in tekstov.« Interno gradivo za študente predmeta Ekonomika turističnih podjetij, Ekonomska fakulteta, Ljubljana.

Mihalič, T., in J. Planina. 2002. Ekonomika turizma. Ljubljana: Ekonomska fakulteta.

Mihalič, T., L. Kneževič Cvelbar, M. Pahor, S. Slapničar, V. Žabkar, T. Dmitrovič, T. Kolar, I. Logar, M. Makovec Brenčič in K. Kuščer. 2009. Oblikovanje modela merjenja uspešnosti poslovanja hotelskih podjetij. Konkurenčnost Slovenije 2006-2013. Konkurenčno gospodarstvo in hitrejša rast. Ljubljana: Ekonomska fakulteta.

Mihaljčič, Z. 2006. Poslovno komuniciranje: učbenik za višje strokovno izobraževanje, izobraževalni program Komercialist. Ljubljana: Založništvo Jutro.

Milfelner, B., D. Mumel in B. Snoj. 2006. »Metaanaliza dveh pristopov k raziskovanju kompleksnih marketinških problemov.« Naše gospodarstvo $52(5 / 6): 37-51$. 
Milost, F. 2002. »Prihodnost je neopredmetena.«V Management, kakovost in razvoj: zbornik 2. strokovnega posveta Visoke sole za management v Kopru z mednarodno udeležbo, Bernardin, I6. -17. november 2001, 33-46. Koper: Fakulteta za management.

Muc, M. B. 2003. »Upravljanje znanja v organizacijah: oblikovanje ustreznega organizacijskega okolja za ustvarjanje znanja.« Andragoška spoznanja 9 (2): 38-45.

Musek Lešnik, K. 2007. Zadovoljstvo potrošnikov: psihološki dejavniki vedenja in zadovoljstva potrošnikov. Ljubljana: IPSOS.

Myers, H. J., in G. M. Mullet. 2003. Managerial Applications of Multivariate Analysis in Marketing. Chicago: American Marketing Association.

Neal, A., M. A. West in M. G. Patterson. 2005. »Do Organizational Climate and Competitive Strategy Moderate the Relationship between Human Resource Management and Productivity? «Journal of Management 3I (4): 492-5I2.

Nemec Rudež, H. 2006. Intelektualni kapital v turizmu. Portorož: Turistica, visoka šola za turizem.

Nemec Rudež, H., in Š. Bojnec. 2007. Ekonomika turizma. Portorož: Turistica, visoka šola za turizem.

Nemec Rudež, H., in T. Mihalič. 2007. »Intellectual Capital in the Hotel Industry: A Case Study from Slovenia.« International Journal of Hospitality Management 26 (I): 188-99.

Nemec, B. 2002. »E-univerza.« Primorska srečanja 26 (255): 8-I I.

Nemec, V. 2005. Kako do uspešnega menedžmenta. Ljubljana: Modrijan.

Noe, R. A., A. D. M. Clarke in H. J. Klein. 2014. »Learning in the Twenty-First-Century Workplace.« Annual Review of Organizational Psychology \& Organizational Behaviour I (I): 245-75.

Orsino, P. S. 1994. Successful Business Expansion: Practical Strategies for Planning Profitable Growth. New York: Wiley.

Pastuović, N. 1999. Edukologija: integrativna znanost o sustavu cjeloživotnog obrazovanja i odgoja. Zagreb: Znamen.

Petty, R., in J. Guthrie. 2000. »Intellectual Capital Literature Review: Measurement, Reporting and Management.« Journal of Intellectual Capital I (2): 155-76.

Planina, J. 1996. Uvodv turizem. Portorož: Turistica, visoka šola za turizem.

Planina, J. 1997. Ekonomika turizma. Ljubljana: Ekonomska fakulteta.

Planina, J., in T. Mihalič. 2002. Ekonomika turizma. Ljubljana: Ekonomska fakulteta. 
Planko, S. 200ı. »Upravljanje z znanjem v organizaciji.« Magistrsko delo, Univerza v Ljubljani.

Plut, H., in T. Plut. 1995. Podjetnik in podjetništvo. Ljubljana: Znanstveno in publicistično središče.

Potočan, V., Š. Kajzer in F. Marn. 2004. Izvedbeni management. Maribor: Ekonomsko-poslovna fakulteta.

Potočnik, V. 2002. Temelji trženja: s primeri iz prakse. Ljubljana: GV Založba.

Pulić, A. 2003. Intelektualni kapital u gospodarstvu. Zagreb: HGK.

Pureber, M. 200I. »Ugotavljanje in merjenje uspešnosti izobraževanja: primer podjetja Revoz.«Andragoška spoznanja 7 (4): 120-23.

Rejc, A. 200I. »Spremljanje učinkovitosti izobraževanja v podjetjih.«Andragoška spoznanja 7 (4): I16-19.

Rešetar, M. 1981. Turističke agencije. Zagreb: Informator.

Riley, P. 200I. Notranji zmagovalec. Ljubljana: Amalietti\&Amalietti.

Rojšek, I. I995. Trženjev majhnem podjetju. Ljubljana: Ekonomska fakulteta.

Roos, J., G. Roos, L. Edvinsson in N. C. Dragonetti. 2000. Intelektualni kapital: krmarjenje po novem poslovnem svetu. Ljubljana: Inštitut za intelektualno lastnino.

Rozman, R., J. Kovač in F. Koletnik. 1993. Management. Ljubljana: Gospodarski vestnik.

Schotter, A., in N. Bontis. 2009. »Intra-Organizational Knowledge Exchange: An Examination of Reverse Capability Transfer in Multinational Corporations.« Journal of Intellectual Capital Io (I): 1 49-64.

Smith, A. 1776. An Inquiry into the Nature and Causes of the Wealth of Nations. London: W. Strahan and T. Cadell.

Starc, A., in B. Ilič. 2007. »Pridobivanje in razvoj znanstvenega in strokovnega človeškega kapitala v zdravstveni negi: študija primera.«Obzornik zdravstvene nege 4I (2/3): 6I-69.

Stewart, T. A. I991. »Brainpower: Intellectual Capital Is Becoming Corporate America's Most Valuable Asset and Can Be Its Sharpest Competitive Weapon.«Fortune, 3. junij, I991.

Stonehous, E. G., in J. Pemberton. 1999. »Learning and Knowledge Management in the Intelligent Organization.« Participation and Empowerment 7 (5): $13 \mathrm{I}-34$.

Subramanian, A., in S. Nilakanta. 1996. »Organizational Innovativeness: Exploring the Relationship between Organizational Determinants of Innovation, Types of Innovations, and Measures of Organizational Per- 
formance.« Omega: International Journal of Management Science 24 (6): $63 \mathrm{I}-47$.

Sundać, D., in N. Švast. 2009. Intelektualni kapital: temeljni čimbenik konkurentnosti poduzeća. Zagreb: Ministarstvo gospodarstva, rada in poduzetništva.

Sveiby, K. E. 2001. »A Knowledge-Based Theory of the Firm to Guide in Strategy Formulation.«Journal of Intellectual Capital 2 (4): 344-58.

Svetlik, I., A. Kohont, K. Gorišek, B. Rozman, J. Lamberger in B. Brank. 2005. Kompetence v kadrovski praksi. Ljubljana: GV Izobraževanje.

Šifrer, J., in M. Bren. 20 I I. SPSS - multivariatne metode v varstvoslovju. Ljubljana: Fakulteta za varnostne vede.

Tajnikar, M. 2000. Tvegano poslovodenje. Portorož: Visoka šola za podjetništvo.

Tomšič, N. 20I5. »Mala in srednje velika podjetja v konkurenčnem trajnostnem razvoju.« Doktorska disertacija, Univerza na Primorskem.

Treven, S. 1998. Management človeških virov. Ljubljana: Gospodarski vestnik.

Uhan, S. 2000. Vrednotenje dela 2: motivacija, uspešnost, plača. Kranj: Moderna organizacija.

Ulrich, D. 1998. $\gg$ Intellectual Capital = Competence $\mathrm{x}$ Commitment. $\ll$ Sloan Management Review 39 (2): 15-30.

Uran, M., in E. Juvan. 2009. Strateški management v turizmu: oblikovanje strategije turizma in vloga deležnikov. Koper: Društvo za akademske in aplikativne raziskave.

Uran, M., in R. Ovsenik. 2006. Razvojni načrt in usmeritve slovenskega turizma 2007-20II. Ljubljana: Ministrstvo za gospodarstvo, Direktorat za turizem.

Vidic, F. 20I2. »Vpliv podjetniške in tržne naravnanosti ter kreiranje znanja na uspešnost podjetij.« Doktorska disertacija, Univerza v Ljubljani.

Vlada RS. 2002. Strategija slovenskega turizma 2002-2006. http://www. mgrt.gov.si/fileadmin/mgrt.gov.si/pageuploads/turizem/turizem_strategija.pdf.

Vlada RS. 20I2. Strategija razvoja slovenskega turizma 20I2-20I6: partnerstvo za trajnostni razvoj slovenskega turizma. Ljubljana: Vlada RS.

von Haller Gilmer, B., in W. J. E. Crissy. 1969. Industrijska psihologija. Ljubljana: Cankarjeva založba.

Vorina, A. 2or 2. Menedžment kakovosti v turizmu. Celje: Fakulteta za komercialne in poslovne vede. 
Weerakoon, T. S. 1996. »Organizational Perfomance - A Stakeholder Concept.« V Proceedings of the First International Research Conference on Quality Management, ur. A. Sohal in M. Terziovski, 80-90. Melbourne: Monash University, Quality Management Research Unit.

Weisinger, H. 2001. Čustvena inteligenca pri delu z ljudmi: neizkoriščen vir uspeha. Ljubljana: Tangram.

Zupan, N. 1998. »Plače in nagrajevanje zaposlenih.« V Management kadrovskih virov, ur. S. Možina, 291-324. Ljubljana: Fakulteta za družbene vede. 


\section{Recenziji}

Avtorja sta v znanstveni monografiji preučevala vpliv dejavnikov človeškega kapitala in organizacijske klime na uspešnost poslovanja turističnih agencij. Omenjeni dejavniki so v veliki meri odvisni od managerjev/ lastnikov/vodij turističnih agencij in tudi od drugih zaposlenih, zato je zelo pomembno, da jim namenjamo čedalje več pozornosti. V znanstveni mononografiji je predstavljena precej neraziskana tema, ki ji je vredno dodati znanstveni prispevek s področja človeškega kapitala, organizacijske klime in turizma ter opredeliti organizacijsko strukturo, vlogo in pomen deležnikov v slovenskem turističnem gospodarstvu. Osnova empiričnega sklopa je bila kvantitativna raziskava v slovenskih turističnih agencijah s pomočjo vprašalnika, ob čemer sta avtorja želela razviti in empirično preveriti konceptualni model, ki prek zastavljenih hipotez ponazarja vpliv dejavnikov človeškega kapitala in organizacijske klime na uspešnost poslovanja turističnih agencij. Teoretični prispevek znanstvene monografije $\mathrm{k}$ znanosti in stroki se odraža $\mathrm{v}$ nadgradnji vsebin in ugotovitev izbranih tujih in domačih raziskav s preučevanega področja z lastnimi ugotovitvami, izhajajočimi iz empiričnega dela raziskave. Empirični prispevek znanstvene monografije $\mathrm{k}$ znanosti in stroki je izvirna ugotovitev prve tovrstne raziskave v Sloveniji in tudi širiše. $S$ kvantitativno lastno empirično analizo sta avtorja predstavila izvirni prispevek, kjer z znanimi statističnimi metodami analizirata vpliv dejavnikov človeškega kapitala in organizacijske klime na uspešnost poslovanja turističnih agencij. Z znanstveno monografijo smo dobili temeljno tovrstno delo v slovenskem 
prostoru, ki je namenjeno širokemu krogu strokovnjakov z različnih področij, hkrati pa bo tudi neizogibni učbenik za študente.

\section{Črtomir Rozman}

\section{II}

Znanstvena monografija pod naslovom Človeški kapital, organizacijska klima in uspešnost poslovanja turističnih agencij preučuje vpliv dejavnikov človeškega kapitala in organizacijske klime na uspešnost poslovanja turističnih agencij. Pri tem je razvit in na podlagi primarnih podatkov empirično preverjen izvirni model linearnih strukturnih enačb s korelacijami med dimenzijami človeškega kapitala, organizacijske klime in uspešnosti poslovanja turističnih agencij. Ugotovljeno je bilo, da med človeškim kapitalom in organizacijsko klimo v turističnih agencijah obstaja pozitivna medsebojna povezava: človeški kapital in organizacijska klima pozitivno vplivata na uspešnost poslovanja turističnih agencij. Redke so raziskave, ki bi ugotavljale vpliv dejavnikov človeškega kapitala in organizacijske klime na uspešnost poslovanja turističnih agencij. Znanstvena monografija prinaša izvirni znanstveni in strokovni prispevek na področju ekonomije in managementa. Rezultati raziskave so zanimivi za izobraževalne institucije, ki se ukvarjajo z izobraževanjem na področju turizma in gostinstva zlasti na visokošolski (univerzitetni) in podiplomski ravni; posebej so zanimivi za turistične agencije in njihove poslovalnice $\mathrm{v}$ Sloveniji, ki so predstavljale ciljno populacijo raziskave. Znanstvena monografija predstavlja izvirno znanstveno delo, ki je relevantno za znanost, stroko in prakso.

\section{Boštjan Antončič}





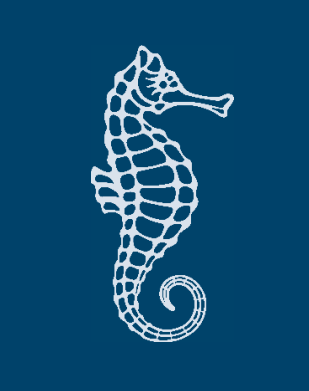

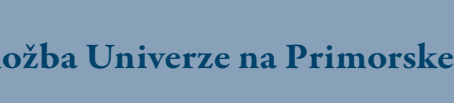

